FABIANA MORANDI JORDÃO

CARACTERIZAÇÃO DA ENZIMA BIFUNCIONAL FARNESIL DIFOSFATO/GERANILGERANIL DIFOSFATO SINTASE E EFEITO DO RISEDRONATO NOS ESTÁGIOS INTRAERITROCITÁRIOS DE

Plasmodium falciparum

Tese apresentada ao Programa de PósGraduação em Biologia da Relação PátogenoHospedeiro do Instituto de Ciências Biomédicas da Universidade de São Paulo, para a obtenção do Título de Doutor em Ciências. 


\section{CARACTERIZAÇÃO DA ENZIMA BIFUNCIONAL FARNESIL DIFOSFATO/GERANILGERANIL DIFOSFATO SINTASE E EFEITO DO RISEDRONATO NOS ESTÁGIOS INTRAERITROCITÁRIOS DE Plasmodium falciparum}

Tese apresentada ao Departamento de Parasitologia do Instituto de Ciências Biomédicas da Universidade de São Paulo, para a obtenção do Título de Doutor em Ciências.

Área de concentração: Biologia da Relação Patógeno-Hospedeiro

Orientador: Prof. Dr. Alejandro Miguel Katzin Versão corrigida. A versão original eletrônica encontra-se disponível tanto na Biblioteca do ICB quanto na Biblioteca Digital de Teses e Dissertações da USP (BDTD) 
DADOS DE CATALOGAÇÃO NA PUBLICAÇÃO (CIP)

Serviço de Biblioteca e Informação Biomédica do

Instituto de Ciências Biomédicas da Universidade de São Paulo

(C) reprodução total

Jordão, Fabiana Morandi.

Caracterização da enzima bifuncional farnesil difosfato/ geranilgeranil difosfato sintase e efeito do risedronato nos estágios intraeritrocitários de Plasmodium falciparum / Fabiana Morandi Jordão. -- São Paulo, 2012.

Orientador: Prof. Dr. Alejandro Miguel Katzin.

Tese (Doutorado) - Universidade de São Paulo. Instituto de Ciências Biomédicas. Departamento de Parasitologia. Área de concentração: Biologia da Relação Patógeno-Hospedeiro. Linha de pesquisa: Potenciais alvos para quimioterapia da malária.

Versão do título para o inglês: Characterization of the bifunctional enzyme farnesyl diphosphate/ geranylgeranyl diphosphate synthase and effect of risedronate intraerythrocytic stages of Plasmodium falciparum.

1. Malária 2. Plasmodium falciparum 3. Proteínas isopreniladas 4. Farnesil difosfato sintase 5. Geranilgeranil difosfato sintase 6. Risedronato I. Katzin, Prof. Dr. Alejandro Miguel II. Universidade de São Paulo. Instituto de Ciências Biomédicas. Programa de PósGraduação em Biologia da Relação Patógeno-Hospedeira III. Título. 


\section{UNIVERSIDADE DE SÃO PAULO \\ INSTITUTO DE CIÊNCIAS BIOMÉDICAS}

Candidato(a):

Fabiana Morandi Jordão.

Título da Tese:

Caracterização da enzima bifuncional farnesil difosfato/ geranilgeranil difosfato sintase e efeito do risedronato nos estágios intraeritrocitários de Plasmodium falciparum.

Orientador(a): $\quad$ Prof. Dr. Alejandro Miguel Katzin.

A Comissão Julgadora dos trabalhos de Defesa da Tese de Doutorado, em sessão pública realizada a considerou

( ) Aprovado(a)

( ) Reprovado(a)

Examinador(a): Assinatura:

Nome:

Instituição:

Examinador(a): Assinatura:

Nome:

Instituição:

Examinador(a): Assinatura:

Nome:

Instituição:

Examinador(a): Assinatura:

Nome:

Instituição:

Presidente: Assinatura:

Nome:

Instituição: 


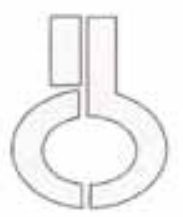

UNIVERSIDADE DE SẢO PAULO INSTITUTO DE CIÊNCIAS BIOMÉDICAS

Cidade Universitária "Armando de Salles Oliveira"

Av, Prof, Lineu Prestes, 2415 - CEP. OS508-000 sio Panlo, sP - Brasil

Telefone :(55) (011) 3091.7733 - telefax : (55) (011) 3091.7438

e-mail: eopateb,usp,br

\section{Certificado}

Certificamos que o protocolo registrado sob $\mathrm{n}^{\circ} 11$ nas fls. 66 do livro 02 para uso de animais em experimentaçāo, sob a responsabilidade do Prof(a) $\operatorname{Dr}(a)$ Alejandre Miguel Katzin, Coordenador(a) da Linha de pesquisa Caracterização funcional da Farnesil difosfato sintase e efeito dos compostos bifosfonatos nos estágios intraeritrocitários de Plasmodium falciparum do qual participou(aram) o(s) alunos Fabiana Morandi Jordão e os pesquisadores Gerhard Wunderlich, Renata Tonhosolo, estả de acordo com os Principios Éticos de Experimentação Animal adotado pela Sociedade Brasileira de Ciência de Animais de Laboratório (SBCAL) e foi aprovado pela COMISSĀO DE ÉTICA EM EXPERIMENTAÇÃO ANIMAL (CEEA) em 31.03.09, com validade de 3 anos.

São Paulo, 01 de abril de 2009.

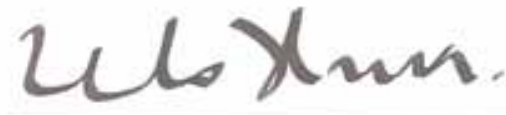

Prof.Dr. WOTHAN TAVARES DE LIMA Coordenador CEEA - ICB/USP

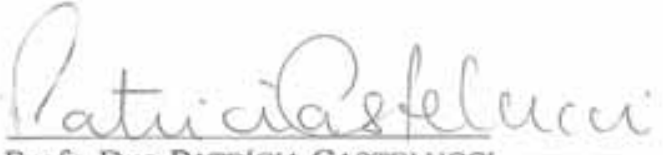

Profa.Dra.PATRICIA CASTELUCCI

Secretária CEEA - ICB/USP 
Dedico esta Tese de Doutorado aos meus pais, Santo e Maria, por acreditarem no meu sonho e a minha irmã Tatiana, pela companhia de sempre. 


\section{AGRADECIMENTOS}

Escrevendo os agradecimentos da minha tese me recordei de diversos momentos vividos durante esses cinco anos. Muitas pessoas me ajudaram com os experimentos e/ou intelectualmente para o desenvolvimento dessa tese, por isso faço questão de agradecê-lás.

- Ao meu orientador Alejandro, que sempre teve paciência e tranquilidade para me transmitir os ensinamentos. Obrigada por acreditar em mim e compreender as minhas dificuldades, devo a minha formação e o meu conhecimento a você, pela sua maneira de ensinar. Esses anos juntos foram imprescindíveis para aquisição dos conhecimentos científicos, mas, além disso, para meu amadurecimento. Durante esses os oito anos que convivemos juntos você foi além de meu orientador, meu grande amigo.

- A minha amiga Emília, pelos diversos anos de convivência no laboratório, com certeza você foi à pessoa essencial para minha formação, com você aprendi a pensar, estudar e escrever e não só isso, com você dividi minhas histórias e meus momentos. Essa amizade aqui formada quero levar-lá para a vida toda.

- Ao meu corientador Gerd por estar sempre disposto a esclarecer as minhas dúvidas em biologia molecular e pelas constantes revisões e considerações realizadas nos artigos desta tese.

- Aos meus companheiros Tarcila e Danilo, amigos que sempre tornaram a minha vida mais leve, dividindo comigo ciência, alegrias, desilusões, estresses, realizações, sonhos, momentos que ficarão para sempre guardado em minha memória. Danilo sinto muito a sua falta, mas sei que mesmo distante você sempre esteve presente, obrigada por tudo. E a Magrela obrigada por ser minha amiga paciente e generosa que sempre esteve ao meu lado nos meus momentos de desânimo e falta de estímulo.

- Aos meus queridos amigos de laboratório, Heloísa, Rodrigo e Alexandre pela convivência diária, pela ajuda, amizade, companherismo e muitos momentos de diversão. Lembrem-se que ainda faço parte do quarteto, continuem sempre me incluindo nos programas de vocês.

- Ao Alexandre por estar sempre disposto a ajudar, concerteza você fez toda a diferença.

- A Val, pela amizade e constante ajuda no laboratório. 
- As amigas do laboratório Márcia, Daniele e Raquel, pela convivência diária e por estarem sempre dispostas a ajudar.

- As minhas queridas amigas que passaram pelo laboratório, Miriam, Sara Rocha e Sarah Machado que continuam minhas amigas até hoje. Agradeço pelas constantes contribuições e pela convivência amigável e divertida dentro e fora do laboratório.

- Aos colegas de laboratório, Herbert, Maria Belén, Fábio e Renata, por alimentarem deste o início o meu gosto pela ciência, e me ensinaram a bioquímica, foi com vocês que tudo começou. Agradeço ao Herbert que com sua tranquilidade e paciência me ensinou por muitas vezes as contas de molaridade. A Bélem pelo exemplo de pesquisadora, com ela aprendi a pensar e fazer ciência. Ao Fábio por seus diversos conhecidos. A Renata pelo seu bom humor durante o longo tempo de convivência no laboratório.

- Jênicer e Ana pelas conversas, companhias e inúmeros momentos de alegria durante nossos almoços.

- A Fernada pela companhia e por toda ajuda fornecida para que eu pudesse vencer as minhas dificuldades.

- A Claudia pelo agradável convivio, apoio e colaboração durante as análises de espectometria de massa.

- Ao Márcio, pela colaboração na biologia molecular, principalmente no sequenciamento das amostras.

- Ao Manuel, por ser sempre prestativo e pela ajuda na minha tentativa frustada de trabalhar com animais.

- A Marinete pelo apoio técnico e por ser sempre solicita, a sua ajuda na preparação dos materiais para esterilização foi imprescindível.

- Ao laboratório do Dr. Luis A. Basso da PUC de Porto Alegre, por disponibilizar seu laboratório durante um mês para meu aprendizado de cinética. Ao Leonardo que se prontificou em me ajudar e a Ardala pelas correções do manuscrito do artigo. Em especial a minha amiga Nani, pelo acolhimento e amizade.

- Ao laboratório da Professora Tânia, e aos meninos André, Alexandre, Felipe e Renato, pela convivência divertida. 
- Aos técnicos, Wolf, Zé Mario, Beth e Zezé, pelo agradável convivio e conversas nos corredores.

- Ao laboratório da Silvia Uliana, por ceder seu laboratório em todos os momentos que precisei.

- A Thais, pela colaboração com os experimentos de cinética enzimática.

- Ao Mauro pela colaboração com meus experimentos de Western blotting.

- A professora Carla Columbano (IQ-USP) pelo uso do photo screen.

- Aos professores do Departamento de Parasitologia, que sempre se mostraram prontos a me ajudar.

- As minhas amigas, Letícia, Liziane, Fernandinha, Kaísa, Bruna, Nana, Mariane e Fabiane, pela amizade verdadeira.

- Aos meus familiares, pai, mãe, Tata, Marcelo, Rose e Alex. Obrigada pela paciência nos meus momentos mais difícies e por sempre acreditarem em mim.

Sem essas pessoas e outras tantas, que podem se considerar citadas, este trabalho não teria um final feliz. 
"Paciência e perseverança têm o efeito mágico de fazer as dificuldades desaparecerem e os obstáculos sumirem".

John Quincy Adamas 


\section{RESUMO}

Jordão MF. Caracterização da enzima bifuncional farnesil difosfato/geranilgeranil difosfato sintase e efeito do risedronato nos estágios intraeritrocitários de Plasmodium falciparum [tese (Doutorado em Parasitologia)]. São Paulo: Instituto de Ciências Biomédicas, Universidade de São Paulo; 2012.

O aumento da resistência do parasita da malária a maioria da drogas antimaláricas disponíveis, torna-se clara, portanto existe a necessidade de pesquisar novos compostos com potencial atividade antimalárica e a detecção de novos alvos. O objetivo da presente tese de doutorado foi inicialmente caracterizar a atividade do risedronato um tipo de bisfosfonatos contendo nitrogênio (BPs-N), utilizado no tratamento da osteoporose, contra as formas intraeritrocitárias do parasita in vitro, além de identificar seu possível mecanismo de ação. A $\mathrm{IC}_{50}$ do risedronato foi de $20 \mu \mathrm{M}$ em culturas de Plasmodium falciparum. A inibição dos parasitas por risedronato pode ser revertida após a adição dos intermediários lineares farnesil difosfato (FPP) e geranilgeranil difosfato (GGPP), concomitantemente com a droga. Análises por cromatografia de camada delgada (TLC) de parasitas tratados com risedronato apresentaram uma redução na biossíntese de farnesol $(\mathrm{FOH})$ e geranilgeraniol $(\mathrm{GGOH})$ após marcação metabólica com $\left[1-{ }^{14} \mathrm{C}\right] \mathrm{IPP}$, indicando que risedronato inibe a síntese desses compostos, podendo sugerir que o mecanismo de ação do risedronato é a inibição da enzima farnesil difosfato sintase (FPPS). Investigamos também o efeito do risedronato na isoprenilação das proteínas. Proteínas de parasitas tratados e marcados com $\left[1-{ }^{3} \mathrm{H}\right] \mathrm{FPP}$ e $[1-$ ${ }^{3} \mathrm{H}$ ]GGPP foram analisadas por SDS-PAGE e demonstrou-se que risedronato é capaz de interferir no processo de isoprenilação de proteínas, inibindo a transferência do grupo FPP para as proteínas farnesiladas. Entretanto, a transferência do GGPP para as proteínas geranilgeraniladas não foi inibida. Consequentemente, a proteína ras mostrou-se inibida e a proteína rab não foi alterada. Estes dados sugerem que a droga está inibindo a enzima FPPS, que é conhecida por ser alvo de BPs-N. Considerando que FPPS é uma enzima chave para a biossíntese de diversos compostos isoprênicos presentes no parasita como: carotenóides, proteínas isopreniladas, dolicol, a alteração no fluxo dessa enzima alteraria toda a biossíntese desses compostos. Neste trabalho foi caracterizada a enzima FPPS de $P$. falciparum mostrando a expressão de uma proteína recombinante fusionada a GST (rPfFPPS). Os substratos IPP, DMAPP, GPP e FPP foram utilizados para determinação da atividade catalítica da enzima, que sintetiza FPP e GGPP como principais produtos, sendo assim considerada uma enzima bifuncional com atividade de FPPS e geranilgeranil difosfato sintase (GGPPS). Os produtos da enzima foram identificados por TLC, cromatografia líquida de alta perfomance (HPLC) e espectrometria de massas. Os valores de $\mathrm{Km}$ para os diferentes substratos foi determinado. Demonstramos também que rPfFPPS é inibida por risedronato. FPPS de Plasmodium ssp. apresenta um potencial alvo para desenho de novos agentes quimioterápicos para o tratamento da malária.

Palavras-chave: Malária. Plasmodium falciparum. Proteínas isopreniladas. Farnesil difosfato sintase. Geranilgeranil difosfato sintase. Risedronato. 


\begin{abstract}
Jordão MF. Characterization of the bifunctional enzyme farnesyl diphosphate/geranylgeranyl diphosphate synthase and effect of risedronate intraerythrocytic stages of Plasmodium falciparum [Ph. D. thesis (Parasithology)]. São Paulo: Instituto de Ciências Biomédicas, Universidade de São Paulo; 2012.
\end{abstract}

The increased resistance of the malaria parasite almost all the antimalarial drugs are available, it becomes clear therefore the need to find new compounds with potential antimalarial and detection of new targets. The aim of this $\mathrm{PhD}$ thesis was initially characterize the activity of the risedronate a kind bisphosphonate containing nitrogen (N-BPs), compound used in the treatment of osteoporosis, intraerythrocytic against forms of the parasite in vivo, and identify its possible mechanism of action. The $\mathrm{IC}_{50}$ for risedronate was $20 \mu \mathrm{M}$. In addition, our results showed that inhibition of parasite may be recovered after the addition of the intermediates linear farnesyl diphosphate (FPP) and geranylgeranyl diphosphate (GGPP) concurrently with the drug. Parasites treated with risedronate and analyzed by thin layer chromatography (TLC) showed a reduction in the biosynthesis of farnesol $(\mathrm{FOH})$ and geranylgeraniol $(\mathrm{GGOH})$ after metabolic labeling with $\left[1-{ }^{14} \mathrm{C}\right] \mathrm{IPP}$, indicating that risedronate inhibits the synthesis of these compounds, suggesting that the mechanism of action of the risedronate is enzyme FPPS. For this check mechanisms of action also investigated the effect of risedronate on protein isoprenylation. Proteins parasites treated and labeled $\left[1-{ }^{3} \mathrm{H}\right] \mathrm{FPP}$ and $\left[1-{ }^{3} \mathrm{H}\right] \mathrm{GGPP}$ were analyzed by SDS-PAGE and demonstrated that risedronate is able to interfere with protein isoprenylation process, which occurs by the presence of these two compounds, risedronate transfer inhibiting group farnesyl diphosphato to farnesylated proteins, however not observed inhibition of transfer of GGPP to geranygeranylated proteins. Consequently, the rab protein was not inhibited while the Ras protein was inhibited. This inhibition may be due to inhibition of the enzyme FPPS which is known to be the target of bisphosphonates. Whereas FPPS is a key enzyme for biosynthesis of various isoprenic compounds present in parasite as carotenoids, proteins isoprenilated, dolichol, and alteration of this enzyme would alter the flow across the biosynthesis of these compounds. We also conduct the characterization of the enzyme from FPPS the P. falciparum showing the expression of a recombinant protein fused to GST (rPfFPPS). The substrates IPP, DMAPP, GPP and FPP were used to determine the catalytic activity of the enzyme, which is FPP and GGPP sintetize as main products, and thus considered a bifunctional enzyme with activity FPPS and GGPPS. The products of the enzyme were confirmed by TLC, HPLC (high-performance liquid chromatography) and mass spectrometry. The values $\mathrm{Km}$ for the various substrates were determineted. We have also demonstrated that rPfFPPS is inhibited by risedronate. FPPS Plasmodium presents a potential target for the design of new chemotherapeutic agents for the treatment of malaria.

Keywords: Malaria. Plasmodium falciparum. Isoprenylated proteins Farnesyl diphosphate synthase. Geranylgeranyl diphosphate synthase. Risedronate. 


\section{LISTA DE ABREVIATURAS E SIGLAS}

\begin{tabular}{|c|c|}
\hline BFs & Bisfosfonatos \\
\hline BFs-N & Bisfosfonatos contendo nitrogênio \\
\hline CDP-ME & 4-(citidina-5' -difosfo)-2C-metil-D-eritritol \\
\hline CDP-MEP & 4-(citidina-5'-difosfo)-2C-metil-D-eritritol 2-fosfato \\
\hline CMK & 4-(citidina-5'-difosfo)-2C-metil-D-eritritol quinase \\
\hline CTP & Citidina trifosfato \\
\hline CDR & Determinação do tamanho da cadeia \\
\hline DMAPP & Dimetilalil difosfato ou difosfato de dimetilalila \\
\hline DOX & 1-deoxi-D-xilulose \\
\hline DOXP & 1-deoxi-D-xilulose 5-fosfato \\
\hline DTT & Dicloro-difenil-tricloroetano \\
\hline DXR & 1-deoxi-D-xilulose 5-fosfato redutase \\
\hline DXS & 1-deoxi-D-xilulose 5-fosfato sintase \\
\hline ESI-MS & Electrospray Ionization Mass Spectrometry \\
\hline FOH & Farnesol \\
\hline FPP & Farnesil difosfato ou difosfato de farnesila \\
\hline FPPS & Farnesil difosfato sintase \\
\hline GAP & Gliceraldeído 3-fosfato \\
\hline GGOH & Geranilgeraniol \\
\hline GGPP & Geranilgeranil difosfato ou difosfato de geranilgeranila \\
\hline GGPPS & Geranilgeranil difosfato sintase \\
\hline $\mathrm{GOH}$ & Geraniol \\
\hline GPP & Geranil difosfato ou difosfato de geranila \\
\hline GST & Glutationa S-Transferase \\
\hline HEPES & Ácido 4-(2-hidroxietil)-1-piperazineetanosulfônico \\
\hline
\end{tabular}




\begin{tabular}{|c|c|}
\hline HMBPP & 1-hidroxi-2-metil-2-(E)-butenil 4-difosfato \\
\hline HMG-CoA & 3-hidroxi-metil-glutaril-CoA \\
\hline HPLC & High Performance Liquid Cromatography \\
\hline $\mathrm{IC}_{50}$ & Concentração inibitória de crescimento de 50\% \\
\hline IPP & Isopentenil difosfato ou difosfato de isopentenila \\
\hline IPTG & Isopropil-3-D-tiogalactopiranosídeo \\
\hline LB & Lennox L Broth Base ou Lennox L Agar \\
\hline MCS & 2C-metil-D-eritritol-2, 4-ciclodifosfato sintase \\
\hline MCT & 2C-metil-D-eritritol, 4-fosfato citidina transferase \\
\hline $\mathrm{MecPP}$ & 2C-metil-D-eritritol 2, 4-ciclodifosfato \\
\hline MEP & 2C-metil-D-eritritol 4-fosfato \\
\hline $\mathrm{MS} / \mathrm{MS}$ & Tandem Mass Spectrometry \\
\hline MVA & Mevalonato \\
\hline OPPS & Octaprenil difosfato sintase \\
\hline PBS & Phosphate Buffer Saline \\
\hline PCR & Polymerase chain reaction \\
\hline SDS-PAGE & Sodium Dodecyl Sulfate Polyacrylamide Gel Electrophoresis \\
\hline SVS & Secretaria de Vigilância em Saúde \\
\hline TLC & Thin Layer Cromatography \\
\hline WHO & World Health Organization \\
\hline $\mathrm{R}_{f}$ & fator de retenção \\
\hline SDS & Dodecil sulfato de sódio \\
\hline$\mu \mathrm{Ci}$ & MicroCurie \\
\hline
\end{tabular}




\section{LISTA FIGURAS}

Figura 1- Ciclo de vida de Plasmodium falciparum.......................................................... 19

Figura 2- Países ou áreas do mundo com risco de transmissão da Malária em 2010.............21

Figura 3- Distribuição de casos de malária confirmados no Brasil (1000 população)............22

Figura 4- Registro de casos de malária e espécies parasitárias ( $P$. falciparum e $P$. vivax).

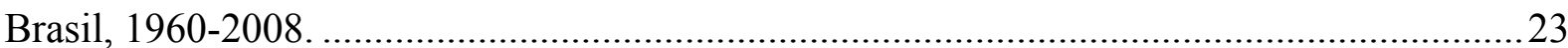

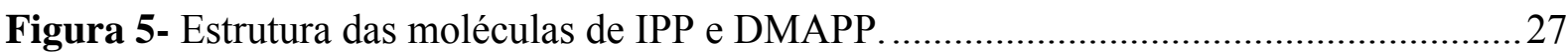

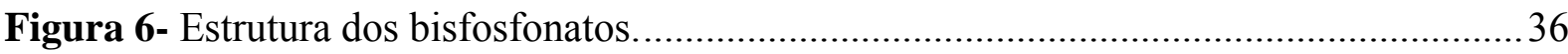

Figura 7- Via dos compostos isoprênicos caracterizados em $P$. falciparum. E a inibição da enzima FPPS por bisfosfonatos 38

Figura 8- Alinhamento de sequência da FPPS de $P$. falciparum. ........................................57

Figura 9- Amplificação por PCR do gDNA do gene Pf11-0295 de P. falciparum.................57

Figura 10- Expressão da versão recombinante da FPPS fusionada a his-tag. .........................58

Figura 11- Comparação da região CLD e domínio FARM das enzimas FPPS bifuncionais..61

Figura 12- Ensaios de westem blotting apartir de anti-soro da FPPS ....................................63 


\section{SUMÁRIO}

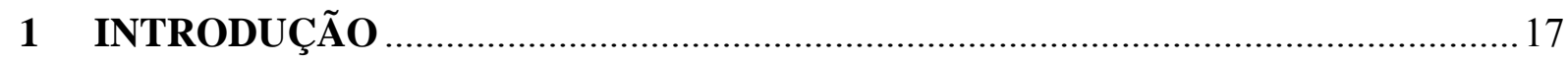

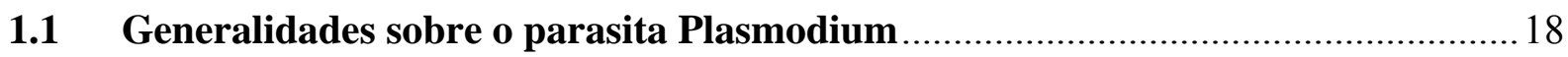

1.2 Epidemiologia da Malária no Mundo e no Brasil..............................................20

1.3 Problemas da Malária e Resistência a antimaláricos........................................24

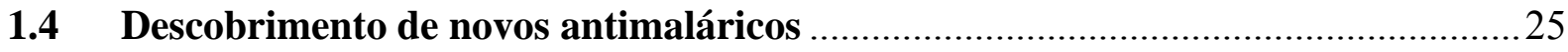

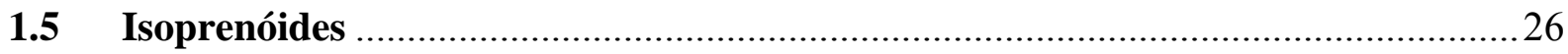

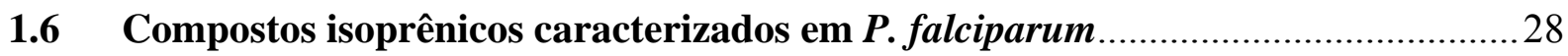

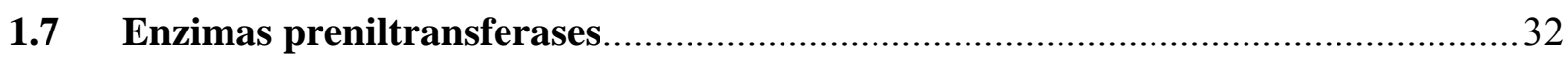

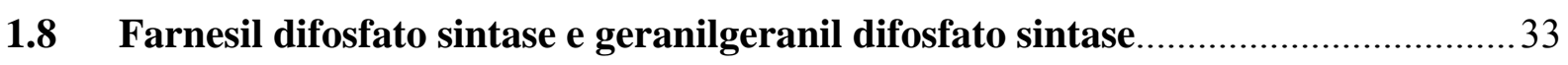

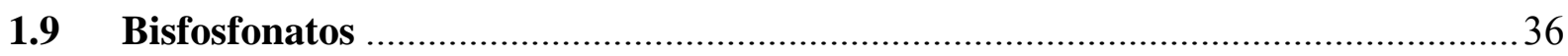

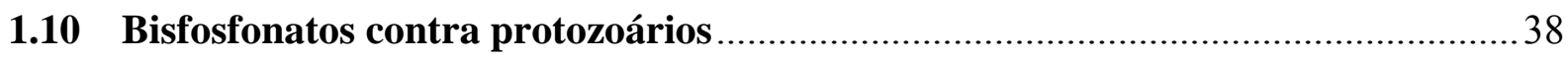

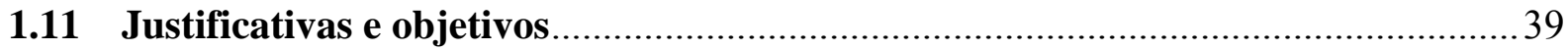

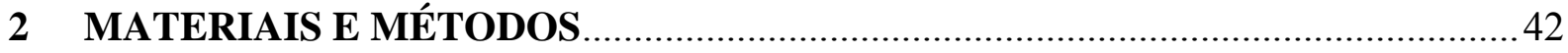

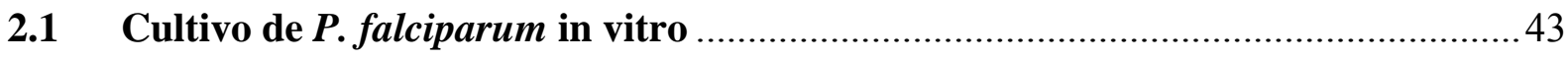

2.2 Separação e purificação dos estágios intraeritrocitários de $P$. falciparum ............. 43

2.3 Teste de inibição com risedronato e ensaio de recuperação .................................. 44

2.4 Tratamento com risedronato e marcação metabólica........................................... 44

2.5 Cromatografia de alta performance fase -reversa (RP-TLC) ….........................45

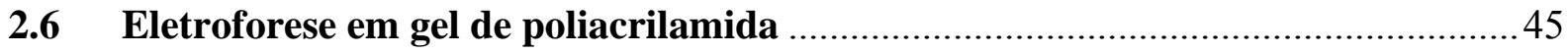

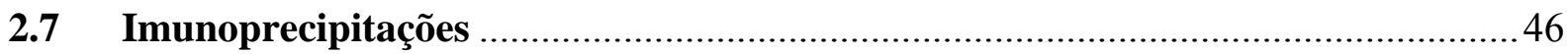

2.8 Escolha da seqüência e alinhamento da Pf11-0295 com a FPPS de outros

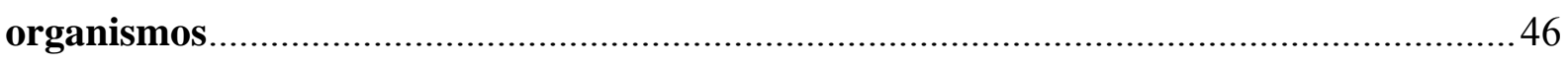

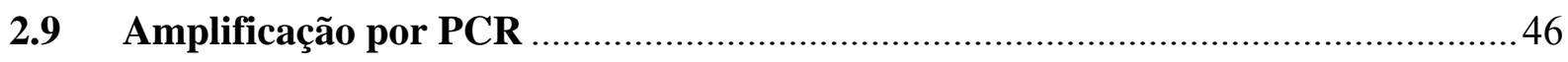

2.10 Expressão e purificação da rPfFPPS de $E$. coli ................................................... 47

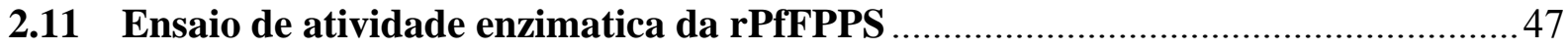

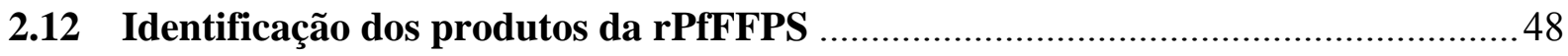

2.13 Investigação por ESI-MS/MS dos produtos GOH, FOH e GGOH........................ 48

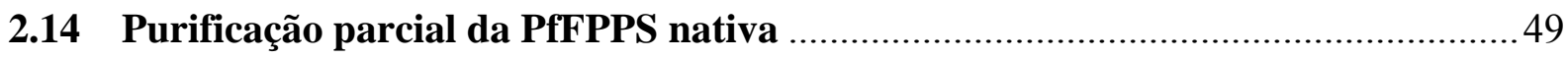

2.15 Determinação dos parâmetros cinéticos da enzima recombinante .........................49

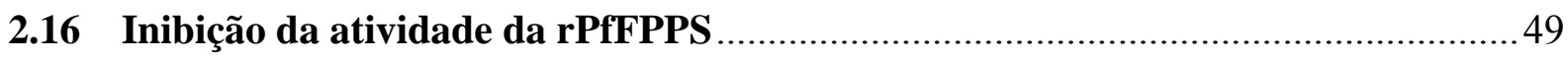

2.17 Imunizações em camundongos com a provável FPPS recombinante ....................50

2.18 Análise dos anticorpos por Western blotting ...........................................................50 
3.1 Atividade de risedronato sobre a biossíntese de isoprenóides lineares e isoprenilação de proteínas

3.2 Caracterização da enzima recombinante farnesil difosfato sintase de $P$. falciparum (rPfFPPS) 56 REFERÊNCIAS 67

APÊNDICE A - In vitro and in vivo antiplasmodial activies of risedronate and its interference with protein prenylation in Plasmodium falciparum. 77

APÊNDICE B - Cloning and characterization of bifunctional enzyme farnesyl diphosphate synthase/geranilgeranyl diphosphate synthase of Plasmodium falciparum. (manuscrito submetido)

APÊNDICE C - Isoprenoid biosynthesis in the erythrocytic stages of Plasmodium falciparum 111

APÊNDICE D - Use of radioactive precursor for biochemical characterization the biosynthesis of isoprenoids in intraerythrocytic stages of Plasmodium falciparum.

APÊNDICE E - Isoprenoid biosynthesis in the erythrocytic stages of Plasmodium falciparum 
1 INTRODUÇÃO 


\subsection{Generalidades sobre o parasita Plasmodium}

Malária é causada por protozoários parasitas do gênero Plasmodium, pertencente ao filo Apicomplexa, família Plasmodiidae. Existem mais de 100 espécies diferentes de Plasmodium, causadoras da malária em várias espécies de animais, bem como em seres humanos. Malária humana é causada por cinco espécies do gênero Plasmodium, denominadas: P. falciparum, P. vivax, P. malariae, $P$. ovale e $P$. knowlesi, considerando que a última é encontrada somente na região sudeste Asiática (Cox-Singh, Singh, 2008). P. falciparum e P. vivax causam a maioria das infecções de malária. $P$. falciparum, provoca a maioria dos casos graves e mortes, embora relatórios recentes indiquem uma subestimativa da gravidade das infecções por P. vivax (Alexandre et al., 2010). P. falciparum é geralmente encontrado em regiões tropicais, como África Subsaariana e no Sudeste Asiático, bem como no Pacífico Ocidental e nos países que compartilham a Amazônia. P. vivax é comum na maior parte da Ásia (especialmente do Sudeste Asiático) e do Mediterrâneo Oriental, e na maioria dos países endêmicos das Américas.

O parasita da malária geralmente é transmitido ao homem pela picada das fêmeas de mosquitos pertencentes ao gênero Anopheles que se infecta ao sugar sangue de uma pessoa infectada. Existem mais de 30 espécies de anofelinos transmissores da malária. P. falciparum possui duas fases distintas em seu ciclo de vida: uma fase assexuada (esquizogonia), que ocorre no hospedeiro vertebrado (homem), e outra sexuada (esporogonia), que ocorre no hospedeiro definitivo invertebrado (mosquito).

Ciclo de vida do parasita no homem: Ao picar o homem, os mosquitos infectados injetam com a saliva os esporozoítos, que entram na corrente sangüínea e, após 14 a 45 minutos da inoculação, alcançam o fígado. Nesse órgão, os esporozoítos invadem as células hepáticas, dando início ao ciclo pré-eritrocitário. Os esporozoítos diferenciam em trofozoítos e, após certo período de tempo se transformam em esquizontes hepáticos, que se rompem e liberam milhares de novos parasitas, os merozoítas, na corrente sanguínea. Os merozoítas invadem os glóbulos vermelhos, dando início ao ciclo intraeritrocitário. Durante o ciclo eritrocitário, o parasita passa por quatro estágios morfologicamente diferentes: anel, trofozoíto, esquizonte e merozoíta. No início do ciclo o parasita encontra-se na forma de anel jovem, diferenciando em trofozoíto e posteriormente transforma-se em esquizontes. Ao final desse estágio, os eritrócitos se rompem, liberando merozoítas na corrente sangüínea. Esses merozoítas invadem outros eritrócitos, dando início a um novo ciclo (no caso de $P$. falciparum, isso ocorre a cada 36-48 horas). Alguns anéis podem se diferenciar em 
gametócitos, podendo ser encontrados no sangue periférico por 60 dias. O mosquito no momento da picada pode ingerir sangue contendo esses gametócitos, iniciando-se assim a fase sexuada no interior do seu instestino.

Figura 1- Ciclo de vida de Plasmodium falciparum.

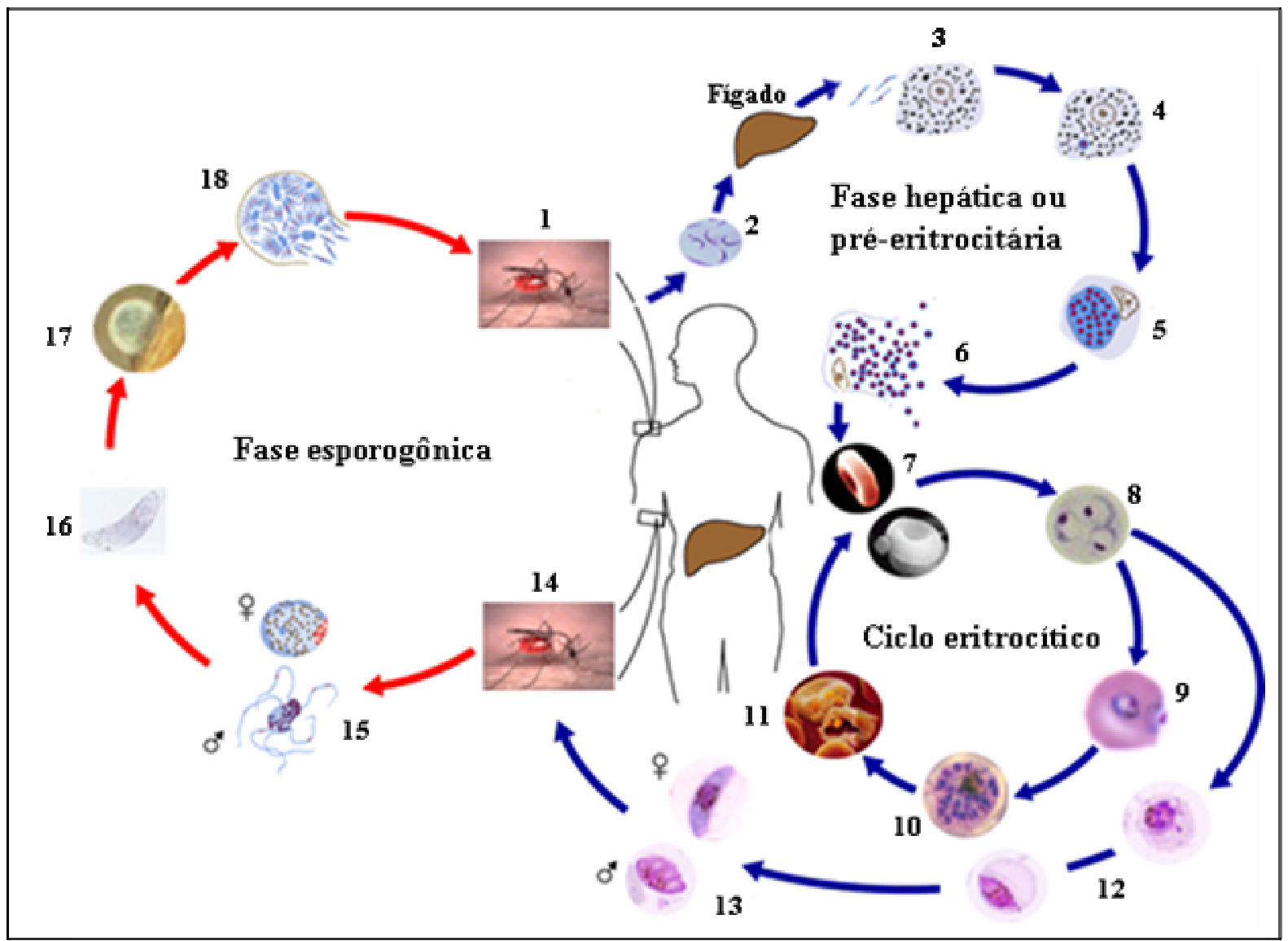

Durante a alimentação, a fêmea infectada do mosquito Anopheles inocula os esporozoítas no hospedeiro humano (1). Os esporozoítas (2) podem então infectar as células hepáticas. Ao invadirem os hepatócitos (3), os esporozoítas transformam-se em criptozoítas (4) e após sofrer uma esquizogonia eles se transformam em esquizontes hepáticos (5). Com a ruptura dos esquizontes hepáticos (6), os merozoítas são liberados na corrente sangüínea e invadem os eritrócitos (7). Após a invasão, os merozoítas começam a se desenvolver nos estágio anel (8), trofozoíta maduro (9) e esquizonte (10), culminando com a ruptura da hemácia e liberação de novos merozoítas, que darão continuidade ao ciclo eritrocítico. Alguns parasitos na forma anel se diferenciam em gametas (12), formando os gametócitos masculino e feminino (13). Ao serem ingurgitados pela fêmea do mosquito (14) durante a alimentação, os gametócitos masculino e feminino se diferenciam no estômago do inseto em microgameta e macrogameta, respectivamente (15). O macrogameta é fecundado pelo microgameta, gerando o zigoto ou oocineto (16) o qual migra para a membrana basal do epitélio estomacal do inseto. $\mathrm{O}$ oocineto então se transforma em oocisto (17). O oocisto sofre uma multiplicação esporogônica, gerando milhares de esporozoítas, que, após a ruptura do oocisto (18), irão se dirigir às glândulas salivares do inseto.

Fonte: Modificado de (CDC, 2012).

Ciclo de vida do parasita no mosquito: Enquanto os anofelinos machos se alimentam somente de néctar e seiva vegetal, as fêmeas necessitam de sangue em sua alimentação, para o amadurecimento de seus ovos e possibilitar a oviposição. Assim, após 
uma fêmea do mosquito Anopheles ingerir sangue de um hospedeiro humano contendo as formas sexuadas do parasita (gametócitos) inicia-se a fase sexuada no interior de seu intestino. Os gametas masculinos e femininos se diferenciam em micro e macrogametas respectivamente e a fecundação, na qual acontece à formação do zigoto ou oocineto, ocorre em poucos minutos após da alimentação sangüínea. O zigoto é a única fase diplóide do parasita. Posteriormente, o zigoto migra através da camada única de células do estômago do mosquito, posicionando-se entre esta e sua membrana basal. $\mathrm{O}$ oocineto se transforma em oocisto ao envolver-se por uma grossa cápsula a qual permite a passagem de nutrientes para a geração dos esporozoítas, formas infectantes, que migram para as glândulas salivares do inseto as quais poderão no momento da picada, ser inoculadas no ser humano.

\subsection{Epidemiologia da Malária no Mundo e no Brasil}

A malária é uma doença infecciosa, sendo uma das cinco principais causas de morbidade e mortalidade no mundo, e até hoje continua sendo um dos principais problemas mundiais de saúde pública. Crianças menores de cinco anos e mulheres grávidas são os grupos mais afetados. A Organização Mundial de Saúde (OMS) estima que morre uma criança a cada 30 segundos de malária na África. De acordo com o Relatório Mundial da Malária 2011, a doença está presente em cerca de 106 países, nas regiões tropicais e subtropicais do planeta, onde 35 países da África Central são responsáveis pelo maior número de casos e óbitos (WHO, 2011).

Comparado a um século atrás, a área de risco da malária reduziou de 53\% para 27\% no planeta e o número de países expostos a algum nível de risco de malária caiu de 140 a 106 países (Development, 2010; WHO, 2011). As estimativas da incidência anual de malária variam amplamente. Segundo as estimativas do Relatório Mundial da Malária 2011, houve 216 milhões de episódios de malária em 2010, dos quais aproximadamente 81\% (174 milhões de casos) foram na Região Africana, sendo que cerca de $91 \%$ foram causados por $P$. falciparum. Mas o número real de casos pode ser muito maior que o número de casos notificados confirmados pelos programas nacionais de controle da malária que foi de apenas $11 \%$ do número estimado de casos (WHO, 2011).

Em 2010, houve 655.000 mortes por malária em todo o mundo, em comparação com 781.000 em 2009 (WHO, 2010, 2011). Estima-se que 91\% das mortes em 2010 foram na Região Africana, seguida pelo Sudeste Asiático (6\%) e Região do Mediterrâneo Oriental (3\%). $86 \%$ das mortes a nível mundial foram em crianças menores de 5 anos de idade (WHO, 
2011). Dos 35 países que responderam globalmente por aproximadamente $98 \%$ das mortes por malária, 30 estão localizados na África sub-saariana, correspondendo a quatro países (Nigéria, República Democrática do Congo, Uganda e Etiópia) que sozinhos, são responsáveis por aproximadamente 50\% das mortes no continente (WHO, 2010).

Figura 2- Países ou áreas do mundo com risco de transmissão da Malária em 2010.

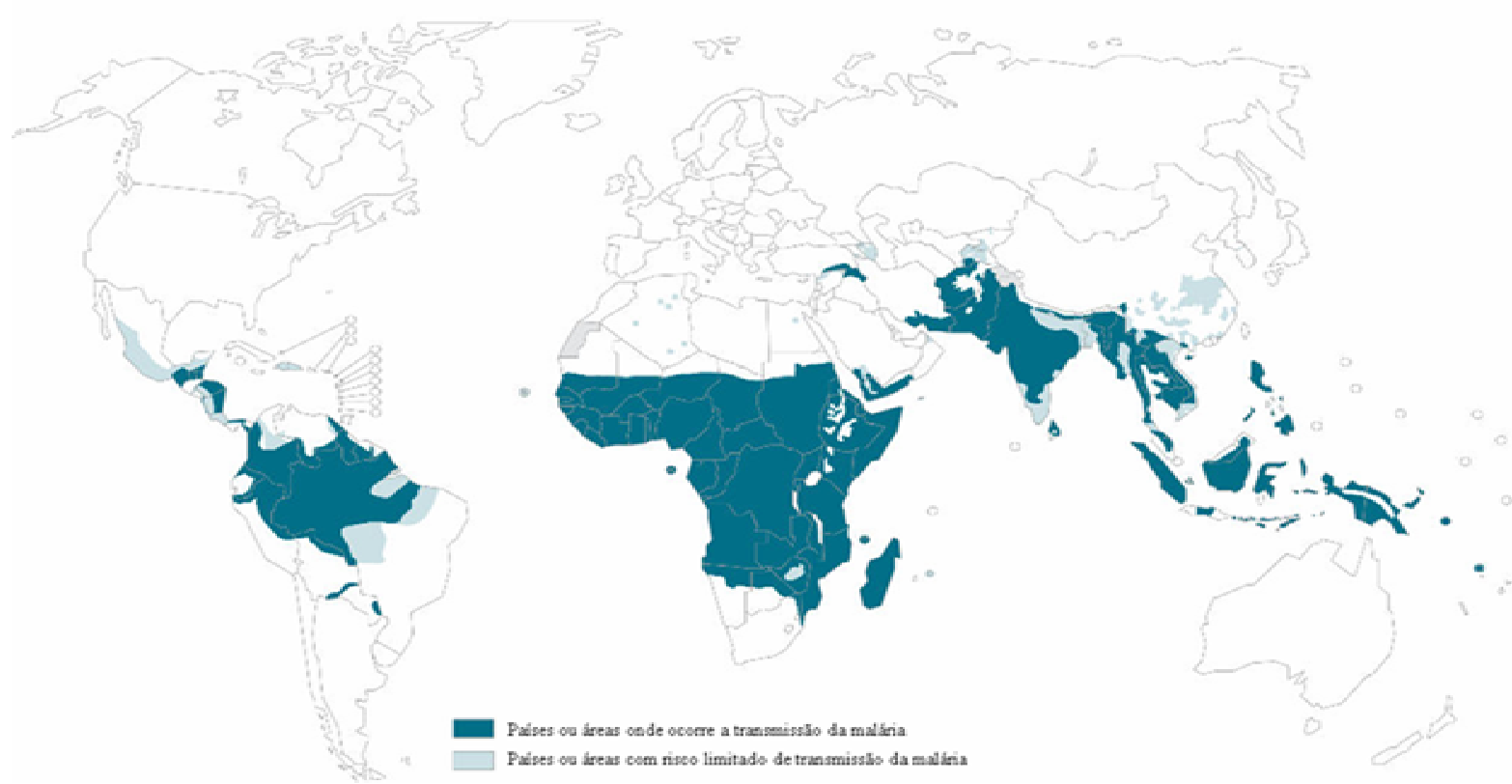

Fonte: (WHO, 2010).

$\mathrm{Na}$ região das Américas, a malária tem como principal característica um declínio na maioria dos países. Em 2010, a detecção ocorreu em 21 países, colocando 20\% da população em risco. Em 2010, cerca 675.000 casos notificados foram confirmados em 19 países, onde a malária por $P$. vivax corresponde $70 \%$ dos casos notificados, entretanto na República Dominicana e Haiti os casos são quase que exclusivamente por P. falciparum. No Suriname a proporção dos casos por P. falciparum caiu de 84\% em 2000 para 38\% em 2010, vinculado a atividade de controle da malária (WHO, 2011).

No Brasil, a transmissão da malária está concentrada nos noves estados da Amazônia Legal (Acre, Amapá, Amazonas, Maranhão, Mato Grosso, Pará, Rondônia, Roraima e Tocantins), que corresponde 99\% dos casos de malária no Brasil. Em 2010, quatro municípios concentraram 86.152 casos, o equivalente a $26 \%$ do total no país - Porto Velho, Anajás (AM), Cruzeiro do Sul (AC) e Manaus. 
Figura 3- Distribuição de casos de malária confirmados no Brasil (1000 população).

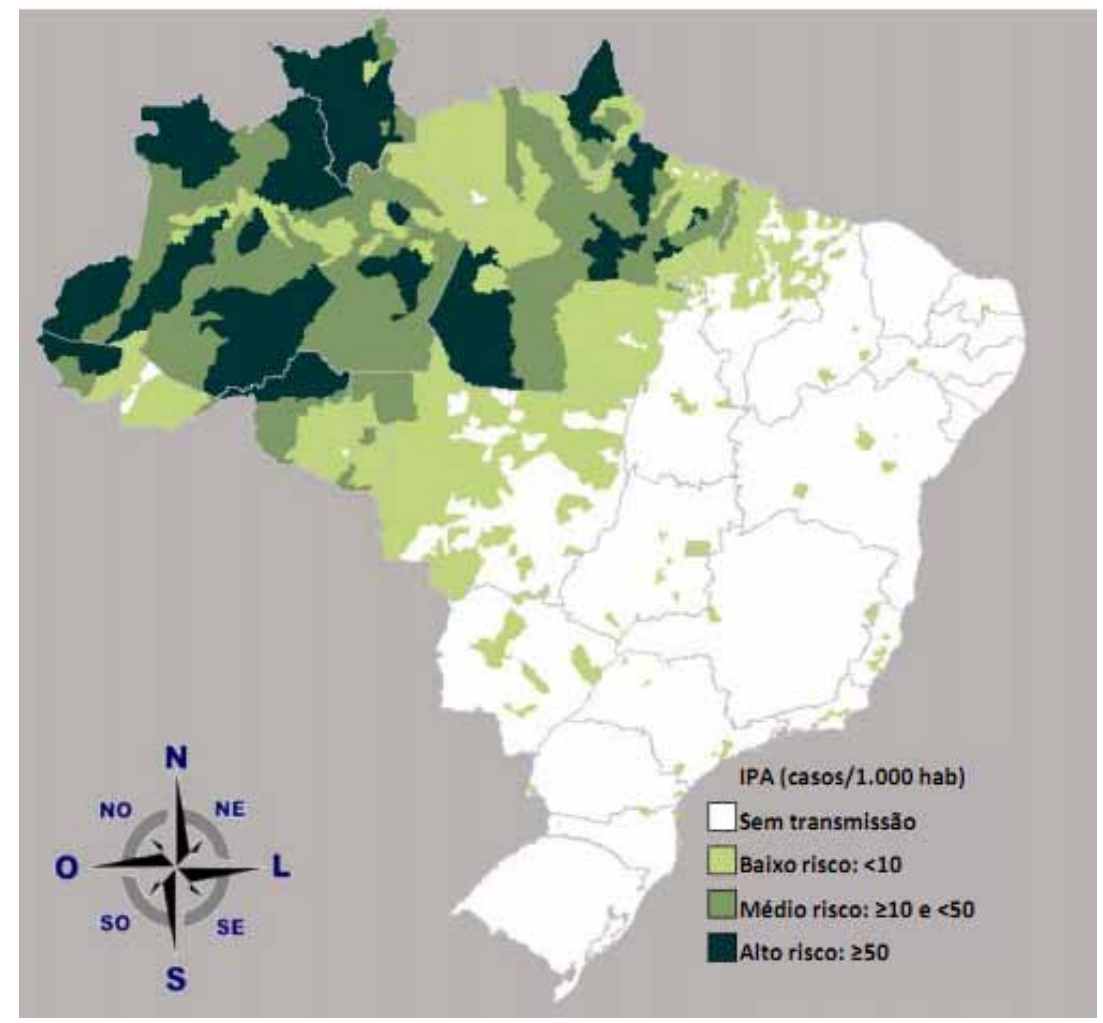

Fonte: (Barbosa, 2011).

Recentemente o Ministério da Saúde divulgou o balanço da situação da malária nos primeiros 10 meses de 2011 na Região da Amazônia Legal. Em toda a Amazônia, de janeiro a outubro, foram registrados 217.298 casos contra os 281.586 casos notificados no mesmo período de 2010. As internações na região também diminuíram de 3.859 em 2010 para 3.215 no ano passado, com redução de $17 \%$. O Acre teve a maior redução do número de casos de malária na Amazônia e no Brasil de janeiro a outubro do ano passado, quando foram notificados no estado 17.176 casos contra os 28.125 casos registrados no mesmo período de 2010 , com redução de $38,9 \%$, percentual bem superior à queda de $23 \%$ observada em toda a região. A diminuição do número de casos foi verificada na maioria dos estados da Amazônia Legal. Além da queda de 38,9\% no Acre, a redução de número de casos de malária se deu em 23\% no Amazonas, 17\% no Maranhão, 28\% no Mato Grosso, 30\% em Rondônia, 33\% em Roraima 33\%, 30\% no Tocantins e 18\% no Pará. Somente no Amapá foi registrado acréscimo de $8 \%$, quando o número de infecções pelo $P$. falciparum passou para 39.978 de janeiro a outubro de 2011 de 24.634 no mesmo período de 2010 . O secretário de Vigilância em Saúde do Ministério da Saúde, Jarbas Barbosa, justificou à diminuição dos casos de malária à descentralização das ações de prevenção e controle da doença, a inclusão de derivados de 
artemisina no tratamento dos pacientes e do atendimento até 72 horas depois do aparecimento dos primeiros sintomas (Barbosa, 2011).

No entanto, de acordo com os dados informados pela Fundação de Vigilância em Saúde (FVS), vinculada à Secretaria de Saúde do Amazônas nos três primeiros meses de 2012, o número de casos de malária aumentou 30\% no Amazônas, em decorrência das cheias nos rios do estado e também a dificuldade de acessar as regiões mais afastadas, como zonas rurais e aldeias indígenas (Barbosa, 2011) .

$\mathrm{Na}$ região extra-amazônica, mais de $80 \%$ dos casos registrados são importados dos estados pertencentes à área endêmica, continente africano e Paraguai. Casos autóctones esporádicos ocorrem em áreas focais restritas desta região. Destacam-se os municípios localizados às margens do lago da usina hidrelétrica de Itaipu; áreas cobertas pela Mata Atlântica nos estados do Espírito Santo, Minas Gerais, Rio de Janeiro, São Paulo e Bahia; a região Centro-oeste, estados de Goiás e Mato Grosso do Sul; e a região Nordeste, estado do Piauí (SUS, 2012).

Até a década de 80 , houve relativa equivalência entre as espécies parasitárias $(P$. vivax e P.falciparum) inclusive com um período de inversão parasitária de 1983 a 1988 com predominância de P. falciparum. A partir de então, nota-se um distanciamento no número de registro das duas espécies, que culminou com a predominância do $P$. vivax, responsável por quase $85 \%$ dos casos notificados em 2008 (SUS, 2012).

Figura 4- Registro de casos de malária e espécies parasitárias ( $P$. falciparum e $P$. vivax). Brasil, 1960-2008.

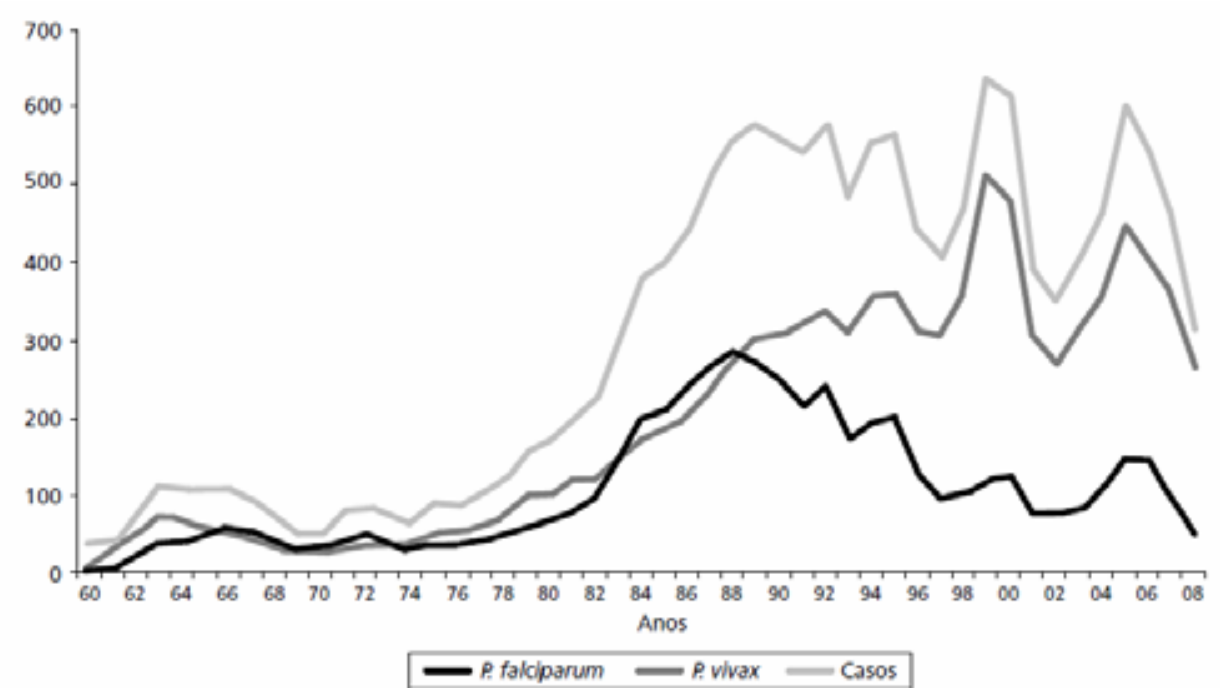

Fonte: (Barbosa, 2011) 


\subsection{Problemas da Malária e Resistência a antimaláricos}

Várias estratégias tem sido utilizadas para o controle da malária no mundo, e estas dependem do tratamento eficiente e rápido dos indivíduos infectados e medidas ambientais, incluindo programas de controle do vetor e prevenção pela estimulação da população do uso de mosquiteiros tratados com inseticidas (WHO, 2010b). A expansão global da doença tem sido atribuída principalmente a alguns fatores como, falhas dos programas de controle do vetor, ausência de uma vacina e aumento da resistência do parasita a drogas corriqueiramente utilizadas na terapia (Sanchez et al., 2010).

O surgimento de resistência se deve à ampla e indiscriminada utilização de antimaláricos. Este fato exerce uma forte pressão selectiva sobre os parasitas da malária para desenvolver elevados níveis de resistência. Por outro lado, a propagação da resistência também está associada à existência de um ciclo sexual no hospedeiro invertebrado onde ocorre uma troca genética. A resistência à droga antimalárica não é o mesmo que falha no tratamento da malária, que nada mais é que a ausência de sucesso na remoção da parasitemia da malária e/ou diminuição dos sintomas clínicos, mesmo com a administração de um antimalárico. Embora a resistência a drogas possa levar a um tratamento fracassado, nem todas as falhas do tratamento são causadas pela resistência às drogas (WHO, 2010b).

O insucesso do tratamento, também pode ser resultado da dosagem incorreta, problemas de adesão ao tratamento, qualidade dos medicamentos, interações com outras drogas, comprometimento da absorção da droga ou erros de diagnóstico do paciente. Todos esses fatores também podem acelerar a propagação de resistência à droga, pela exposição dos parasitas a níveis de droga inadequados (WHO, 2010b). Para avaliar se a cepa é resistente a um antimalárico, a OMS recomenda alguns métodos como: avaliação in vivo da eficácia terapêutica; genotipagens moleculares para distinguir entre re-infecções e recrudescência; estudos in vitro de susceptibilidade do parasita aos medicamentos em cultura e identificação de marcadores moleculares (WHO, 2010b).

Entre os principais compostos antimaláricos recomendados pela OMS para o tratamento da malária estão as aminoquinolinas (cloroquina, amodiaquina, primaquina,

quinina, mefloquina), antifolatos (sulfadoxina), diaminopirimidina (pirimetamina) e sesquiterpenos lactonas (artemisinina, artemether, artesunato) e alguns antibióticos (WHO, 2010a). Com exceção dos derivados de artemisinina foram notificados casos de resistência para todos esses antimaláricos em muitas regiões endêmicas da malária (Ekland, Fidock, 2008). 
A resistência aos fármacos antimaláricos tem sido descrito em duas das cinco espécies do parasita da malária que infectam o homem, P. falciparum e P. vivax. P. falciparum desenvolveu resistência a quase todos os antimaláricos de uso corriqueiro, embora a distribuição geográfica de resistência às drogas variou grandemente. O parasita da espécie $P$. vivax tem se mostrado, em algumas zonas, resistentes a cloroquina e/ ou primaquina.

\subsection{Descobrimento de novos antimaláricos}

Com a resistência dos parasitas aos antimaláricos, a descoberta e desenvolvimento de novos e eficazes agentes antimaláricos se faz necessária. Este objetivo pode ser alcançado de três formas: (i) concentrando-se em alvos dos parasitas previamente caracterizados, para gerar novos fármacos, (ii) pela identificação de novos alvos potenciais para a quimioterapia de parasitas da malária (Ridley, 2002) ou (iii) através da realização de testes em bibliotecas de drogas já existentess (Guiguemde et al., 2010).

O seqüenciamento completo do genoma do hospedeiro mamífero, do vetor da malária (Holt et al., 2002) e de diversos parasitas causadores da malária (Carlton et al., 2002; Gardner et al., 2002), tem nos levado a uma melhor compreensão das funções dos genes e a descoberta de vias metabólicas presentes no parasita que estão ausentes em humanos, que são apontadas como possíveis novos alvos terapêuticos.

Todos os organismos do Phylum apicomplexa possuem uma organela conhecida como apicoplasto, considerada um plastídio não fotossintetizante (McFadden, Waller, 1997). Acredita-se que essa organela tenha tido origem de uma endossimbiose secundária entre um eucarioto fotossintetizante e um eucarioto não fotossintetizante, sendo o primeiro fotossintetizante proveniente de uma endossimbiose primária entre uma cianobactéria e um eucarioto não fotossintetizante (Gleeson, 2000; Kohler et al., 1997; Roos et al., 2002; Sato et

al., 2000; Wilson, 2002). Acredita-se também que, no caso dos apicomplexas, a endossimbiose secundária tenha tido como eucarioto fotossintetizante uma alga verde (Funes et al., 2004; Van de Peer et al., 1996; van Dooren et al., 2000). Tais hipóteses são corroboradas pela presença de quatro membranas envolvendo esta organela e pela semelhança entre o genoma do apicoplasto e o genoma de algas verdes (Marechal, Cesbron-Delauw, 2001; Wilson, Williamson, 1997).Durante a evolução dessa organela e do parasito, todos os genes envolvidos na fotossíntese foram perdidos (Kohler et al., 1997; Wilson et al., 1996). A quase totalidade dos genes existentes no plastídio foi transferida para o genoma nuclear (Boucher, Doolittle, 2000; Waller et al., 1998; Waller, McFadden, 2005). O apicoplasto tem 
seu próprio genoma, contendo um pequeno número de genes (35 kb de DNA circular), que envolve cerca de 400 proteínas codificadas por genes nucleares e envolvidos pela organela através de uma via secretora. Um predito proteoma mapeou algumas vias putativas presentes no apicoplasto como, a biossíntese de acidos graxos, clusters de ferro-enxofre, biossíntese do heme e biossíntese de isoprenóides (Ralph et al., 2004). Estas vias metabólicas são distintas das vias encontradas no hospedeiro humano, tornando assim, as vias do apicoplasto indispensáveis para serem elucidadas.

O apicoplasto tem uma função importante para a sobrevida do parasita. Recentemente demostrou-se que a deleção do apicoplasto de P. falciparum e a concomitante suplementação com precursores da via de isoprenoídes é essencial durante o crescimento nos estágios sanguíneos (Yeh, DeRisi, 2011). Sendo assim, evidencia-se a grande importância dessa organela para o parasito e a via de isoprenóides como potencial alvo para o desenvolvimento de novas drogas antimaláricas.

\subsection{Isoprenóides}

Isoprenóides são produtos naturais conhecidos por serem os compostos mais abundantes e mais diversos estruturalmente. Os mais de 23.000 compostos isoprênicos identificados até agora exercem uma variedade de funções biológicas em eucariontes, bactéria e arquea. Por exemplo, esteróides são isoprenóides cíclicos, que possuem distintas funções biológicas, como hormônios. Carotenóides são necessários para os organismos fotossintéticos e podem atuar como antioxidantes. Ubiquinona, menaquinona e plastoquinona estão envolvidas no transporte de elétrons; dolicois estão envolvidos entre outras funções, na glicosilação de proteínas e biossíntese de âncoras de proteínas. Retinóides estão envolvidos em morfogêneses. Proteínas preniladas incluindo Ras e outras proteínas G estão envolvidas em vias de tradução de sinais específicas.

Todos os isoprenóides derivam de um precursor comum, o isopentenil difosfato (IPP) e seu isômero dimetilalil difosfato (DMAPP) (Clarke, 1992). A via de biossíntese de isoprenóides ocorre em duas fases, à primeira fase (metabolismo primário) responsável pela formação das unidades IPP e DMAPP. E a segunda fase, responsável pela biosssíntese de isoprenóides secundários, a partir da condensação de IPP e DMAPP para a síntese de isoprenóides lineares. Duas distintas e independentes vias podem biossintetizar IPP: a via clássica do mevalonato (MVA) e a via independente do mevalonato. 
Figura 5- Estrutura das moléculas de IPP e DMAPP.

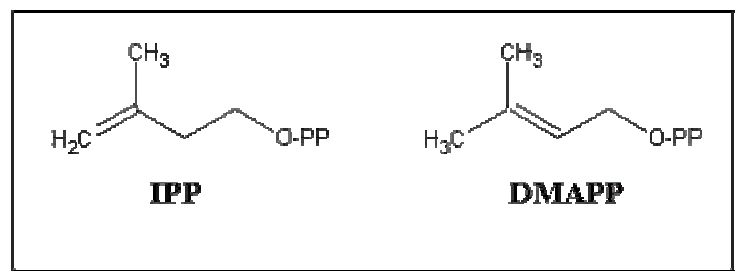

A via do mevalonato inicia com a conversão de acetil-CoA em 3-hidroxi-metilglutaril-CoA seguindo por redução, fosforilação e descarboxilação para gerar IPP. Esta via está presente em fungos e animais (Spurgeon, Porter, 1981). A outra via independente do mevalonato, também conhecida como 1-deoxi-D-xilulose-5-fosfato (DOXP) ou 2C-metil-Deritritol 4-fosfato (MEP) começa com a condensação do piruvato com gliceraldeído-3-fosfato (GAP) produzindo 1-deoxi-D-xilulose-5-fosfato (DOXP), o metabólito chave da via, por meio da 1-deoxi-D-xilulose (DOX) sintetase (DXS), posteriormente a enzima DOXP reductoisomerase (DXR) catalisa o rearranjo intramolecular e a redução na transformação da DOXP em MEP. Em seguida MEP é ligado à molécula de CTP para produzir 4-difosfocitidil2-C-metil-D-eritritol (CDP-ME) pirofosfato em uma reação catalisada pela MEP citidiltransferase (MCT). A enzima 4- (citidina-5'-difosfato)-2C-metil-eritritol quinase (CMK), dependente de ATP que fosforila o CDP-ME produzindo 4-difosfocitidil-2-C-metil-Deritritol-2-fosfato (CDP-MEP). No quinto passo, o CDP-ME é convertido em 2C-metil-Deritritol-2,4-ciclodisfosfato (MEcPP) e CMP pela cMEPP sintase, onde este produto é reduzido a 1-hidroxi-2-metil-2-(E)-butenil 4-difosfato (HMBPP) por uma redutase codificada pelo gene GcpE, posteriormente a enzima codificada pelo gene lytB converte HMBPP em IPP e DMAPP.

A via MEP está presente em plantas superiores, algas e alguns eucariontes, incluindo $P$. falciparum (Jomaa et al., 1999). Nosso grupo demonstrou que essa via está funcionalmente ativa em $P$. falciparum, isolando e caracterizando os intermediários DOXP, MEP, CDP-ME, CDP-MEP-2P e ME2,4-cPP da via MEP. O estudo, além de confirmar a presença da via no parasita, caracterizou pela primeira vez a biossíntese de piridoxona-5-fosfato em um protozoário do filo Apicomplexa (Cassera et al., 2004).

As enzimas da via MEP são apontadas como prováveis alvos para a ação de drogas, pois são encontradas em vários organismos patogênicos e por estarem ausentes em humanos. Fosmidomicina, um antibiótico produzido por Streptomices lavendulae, tem sido identificado como um potente inibidor da enzima DOXP reductoisomerase (Kuzuyama et al., 1998). 
Jomaa et al.(1999) caracterizou dois genes da via MEP em P. falciparum, que codificam a DOXP sintase e DOXP redutoisomerase (Jomaa et al., 1999).

Demonstrou-se também que a fosmidomicina possui atividade inibitória in vitro em culturas de $P$. falciparum e contra $P$. vinckei in vivo em camundongos infectados (Jomaa et al., 1999). Um derivado da fosmidomicina, a FR900098, que também inibe a enzima DXR, foi testada em camundongos, apresentando bons resultados (Reichenberg et al., 2001). Quando a fosmidomicina passou para testes clínicos observou-se uma recrudescência da doença, em alguns pacientes tratados. Apesar disso, a fosmidomicina começou a ser testada em modelo murino em associação com outros antimaláricos clinicamente utilizados, destacando-se a associação entre fosmidomicina e clindamicina (Wiesner et al., 2002). Atualmente a associação fosmidomicina/clindamicina tem sido testada clinicamente em humanos, mostrando bons resultados (Borrmann et al., 2004; Borrmann et al., 2006; Oyakhirome et al., 2007). Recentemente foi demonstrado que a fosmidomicina além de inibir a DOXP reductoisomerase, age indiretamente sobre um segundo alvo, a enzima MEP citidiltransferase (Zhang et al., 2011).

Parasitas tratados com fosmidomicina recuperaram por completo seu crescimento quando meio de cultura contendo metabólitos da via de isoprenoídes foram acrescentadas ao cultivo, essas observações demonstram que fosmidomicina é capaz de bloquear a biossíntese dos precursores de isoprenoídes. E que a suplementação com precursores da via de isoprenoídes concomitante com a deleção do apicoplasto, sugerem que a única função essencial do apicoplasto no parasita é a biossíntese da via de isoprenóides (Yeh, DeRisi, 2011). A localização da via MEP no apicoplasto já havia sido sugerido anteriormente quando sugeriu-se que genes relacionados a via MEP em $P$. falciparum possuiam um sítio de direcionamento para o apicoplasto, indicando que a via poderia estar localizada nesta organela (Ralph et al., 2004).

\subsection{Compostos isoprênicos caracterizados em $P$. falciparum}

Após a síntese do IPP e DMAPP, esses compostos se condensam, ocorrendo uma elongação inicial da cadeia isoprênica e a síntese de isoprenoídes lineares, como: geranil difosfato (GPP), farnesil difosfato (FPP), geranilgeranil difosfato (GGPP) e poliisoprenóides, que são intermediários para biossíntese de diferentes produtos derivados da biossíntese de isoprenóides como: dolicol, ubiquinona, carotenoídes, menaquinona e proteínas isopreniladas. Até o momento não está claro qual ou quais dos produtos finais do metabolismo de 
isoprenóides são essenciais para a sobrevida do parasita, entretanto eles estão sendo caracterizados no parasita e, em alguns casos suas funções definidas. Formas intraeritrocíticas de $P$. falciparum facilmente metabolizam os compostos $\left[1-{ }^{3} \mathrm{H}\right] \mathrm{FPP}$ e $\left[1-{ }^{3} \mathrm{H}\right] \mathrm{GGPP}$, quando eles são adicionados ao meio de cultura, permitindo a identificação de isoprenóides posteriores a estes precursores.

Por marcação metabólica dos parasitas com $\left[1-{ }^{3} \mathrm{H}\right] \mathrm{FPP}$ e $\left[1-{ }^{3} \mathrm{H}\right] \mathrm{GGPP}$, identificaram a presença de dolicol fosfato e dolicol difosfato de 55 e 60 carbonos (11/12 unidades isoprênicas) em diferentes estágios intraeritrocíticos de $P$. falciparum. Este estudo foi a primeira demonstração de dolicol de cadeia curta no filo Apicomplexa (Couto et al., 1999).

Em P. falciparum, a biossíntese de ubiquinona ou coenzima $\mathrm{Q}$ envolve dois passos principais: síntese do anel benzoquinona pela via chiquimato e síntese da cadeia lateral de isopreno pela via MEP. Nosso grupo demonstrou que o $P$. falciparum tem uma via ativa para a biossíntese da cadeia isoprênica de coenzima Q. Além disso, o parasita é capaz de sintetizar compostos homólogos desta molécula, dependendo do precursor utilizado para a marcação metabólica. Quando a marcação foi realizada com $\left[1{ }^{3} \mathrm{H}\right] \mathrm{FPP}$, foi detectado coenzima Q com uma cadeia isoprênica com 40 carbonos (Q8), enquanto a marcação com $\left[1-{ }^{3} \mathrm{H}\right] \mathrm{GGPP}$ resultou em uma molécula de Q9 (45 carbonos). Assim, o parasita biossintetiza cadeias isoprênicas ligadas ao anel benzoquinona da coenzima Q de 8 e 9 unidades isoprênicas e a síntese dessas são inibidas por nerolidol, cujo efeito é interferir no alongamento das cadeias isoprênicas (de Macedo et al., 2002). Diferenças significativas no comprimento das cadeias laterais de ubiquinonas de organismos diferentes são observadas, sugerindo que preniltransferases específicas estão envolvidas na síntese de cadeias laterais, como por exemplo em Saccharomyces cerevisiae a cadeia lateral da ubiquinona é de 30 carbonos, em ratos esta cadeia lateral possui 45 carbonos e em humanos esta cadeia possui 50 carbonos, sintetizados pelas respectivas enzimas hexaprenil difosfato sintase, solanesil difosfato sintase e decaprenil difosfato sintase (Ashby, Edwards, 1990; Teclebrhan et al., 1993). Estas diferenças no comprimento da cadeia lateral dos compostos isoprênicos encontrados em seres humanos e $P$. falciparum poderia possivelmente ser explorada como alvos de drogas. Nosso grupo clonou e expressou uma octaprenil difosfato sintase (OPPS) de P. falciparum, cuja principal função é o alongamento da cadeia isoprênica que se liga ao anel benzoquinona (Tonhosolo et al., 2005; Yeh, DeRisi, 2011). Diferentes terpenos testados apresentaram ação inibitória na biossíntese de dolicol e da cadeia isoprênica ligada ao anel de benzoquinona das ubiquinonas (Rodrigues Goulart et al., 2004). 
Nosso grupo previamente demonstrou que estágios intraeritrocíticas de $P$. falciparum foram capazes de biossintetizar alguns compostos poliisoprênicos quando $\left[1-{ }^{3} \mathrm{H}\right] \mathrm{GGPP}$ foi utilizado como precursor metabólico (Couto et al., 1999). Tendo em vista que, plastídios de plantas e algas possuem sítios para a síntese de polisoprenoídes incluindo carotenos, nosso grupo investigou a possibilidade de $P$. falciparum biossintetizar carotenóides, onde em outros organismos GGPP é utilizado como precursor. Tonhosolo et al. (2009) mostrou pela primeira vez que a biossíntese de carotenóides é funcionalmente ativa na fase intraeritrocítica de $P$. falciparum. Neste trabalho, foi demonstrado que a versão completa da enzima PfOPPS, descrita anteriormente, também possuia atividade de fitoeno sintase. Mostrou-se também que norflurazon, um herbicida que inibe a biossíntese de carotenóides em plantas superiores e microalgas, foi capaz de inibir o crescimento in vitro de $P$. falciparum. Esta inibição pode ser parcialmente revertida através da adição de licopeno, um produto da via de carotenóides (Tonhosolo et al., 2009). A função dos carotenóides no parasita da malária é desconhecida. No entanto, em Toxoplasma gondii, foi demonstrada a biossíntese do fitohormônio ácido abscísico, um produto final da biossíntese de carotenóides que controla a sinalização de cálcio dentro do parasita apicomplexa (Nagamune et al., 2008). Pelo fato da via de biossíntese de carotenóides ser ausente em humanos, ela pode ser explorada como um novo alvo para desenvolvimento de drogas antimaláricas.

Vitaminas são componentes essenciais da dieta humana. Em contraste, o P. falciparum pode sintetizar certas vitaminas de novo. Além disso, a falta destas vias no hospedeiro mamífero implica que a inibição destas vias no parasita pode ser explorada como alvo de novos antimaláricos. Em P. falciparum, demostrou-se que as fases intraeritrocíticas têm uma via ativa para a biossíntese de menaquinona-4 (MQ) e que MQ poderia substituir a função fisiológica da ubiquinona em condições anaeróbias, na cadeia respiratória. Neste mesmo trabalho, foi demonstrado também que $P$. falciparum pode alterar o conteúdo de quinona, dependendo da condição de tensão de oxigênio no meio de cultura. Além disso, mostraram que a mesma droga (Ro48-8071) que inibe a MQ de Mycobacterium tuberculosis também suprimiu a biossíntese de MQ de P. falciparum além de inibir o crescimento do parasita (Tonhosolo et al., 2010). Um estudo recente do nosso grupo mostrou que o parasita biossintetiza também tocoferol (vitamina E) e que a biossíntese pode ser inibida por acido úsnico (Sussmann et al., 2011).

O intermediário FPP é usado no processo de modificação pós-traducional de proteínas. Estudos têm demonstrado que FPP e GGPP são os mais comuns isoprenóides ligados a proteínas. Os grupos isoprenóides são ligados pós-traducionalmente a resíduos de cisteína na 
posição $\mathrm{C}$ terminal das proteínas através de uma ligação tioéter. Várias proteínas que são submetidas a estas modificações têm sido identificados e muitas participam de importantes funções regulatórias das células, em particular as vias de transdução de sinal (Zhang, Casey, 1996). Prenilação de proteínas é um fenômeno geral em células eucarióticas e tem sido descrito em vários parasitas protozoários como Giardia lamblia, Trypanosoma brucei. Entamoeba histolytica, T. gondii (Field et al., 1996; Ibrahim et al., 2001; Lujan et al., 1995; Shen et al., 1996), e P. falciparum (Chakrabarti et al., 2002).

O primeiro trabalho evidenciando a presença de proteínas Ras-like em P. falciparum foi publicado em 1994 (Thelu et al., 1994). Dois anos mais tarde confirmou-se a presença de proteínas Ras em P. falciparum, identificando proteínas Rab 4 e 6 (Jambou et al., 1996). Chakrabarti et al. (1998) demonstraram a atividade de preniltransferases no parasito, e que algumas proteínas desse parasito eram marcadas metabolicamente com $\left[{ }^{3} \mathrm{H}\right]$ farnesol e $\left[{ }^{3} \mathrm{H}\right]$ geranilgeraniol. Por meio do uso de inibidores de FTase e GGTase, eles demonstraram que essa modificação pós-traducional de proteínas é essencial para o metabolismo de $P$. falciparum, descobrindo um novo e interessante alvo para o desenvolvimento de novos quimioterápicos contra o parasito (Chakrabarti et al., 1998).

Nosso grupo demonstrou que as três formas intra-eritrocitárias de P. falciparum biossintetizam isoprenóides que se ligam a proteínas (D'Alexandri et al., 2006; Moura et al., 2001). Marcações metabólicas com $\left[1-{ }^{3} \mathrm{H}\right]$ GGPP mostraram bandas de proteínas com pesos moleculares aproximados de 6-7 kDa, 21-28 kDa nos três estágios parasitários. Quando o precursor utilizado foi o $\left[1-{ }^{3} \mathrm{H}\right] \mathrm{FPP}$, além das bandas com peso molecular semelhante às marcadas com $\left[1-{ }^{3} \mathrm{H}\right] \mathrm{GGPP}$, uma nova banda com peso molecular aproximado de $50 \mathrm{kDa}$ foi detectada. Nosso laboratório também demonstrou que proteínas marcadas metabolicamente com $\left[1-{ }^{3} \mathrm{H}\right] \mathrm{FPP}$ e $\left[1-{ }^{3} \mathrm{H}\right] \mathrm{GGPP}$ foram imunoprecipitadas com anticorpos anti-Ras, anti-Rho e anti-Rap, mostrando que possivelmente essas proteínas estão presente em $P$. falciparum (Rodrigues Goulart et al., 2004). No mesmo trabalho, foi demonstrado que limoneno, um terpeno presente em plantas, inibiu o crescimento dos parasitas atrasando a maturação do estágio de anel para trofozoíto e também foi demonstrado que inibe a incorporação dos grupos isoprênicos em proteínas. Rodrigues Goulart et al. (2004) demonstrou que terpenos (farnesol, nerolidol, limoneno e linalol) levaram a uma diminuição na quantidade de proteínas isopreniladas no estágio de esquizonte de $P$. falciparum (Rodrigues Goulart et al., 2004).

Na figura 6 se descrevem a variedade de compostos diferentes já caracterizados por nosso grupo em $P$. falciparum que podem ser originados a partir das moléculas de IPP e DMAPP, participando dos mais diversos e importantes eventos do metabolismo celular. 
Figura 6- Compostos isoprênicos caracterizados em P. falciparum.

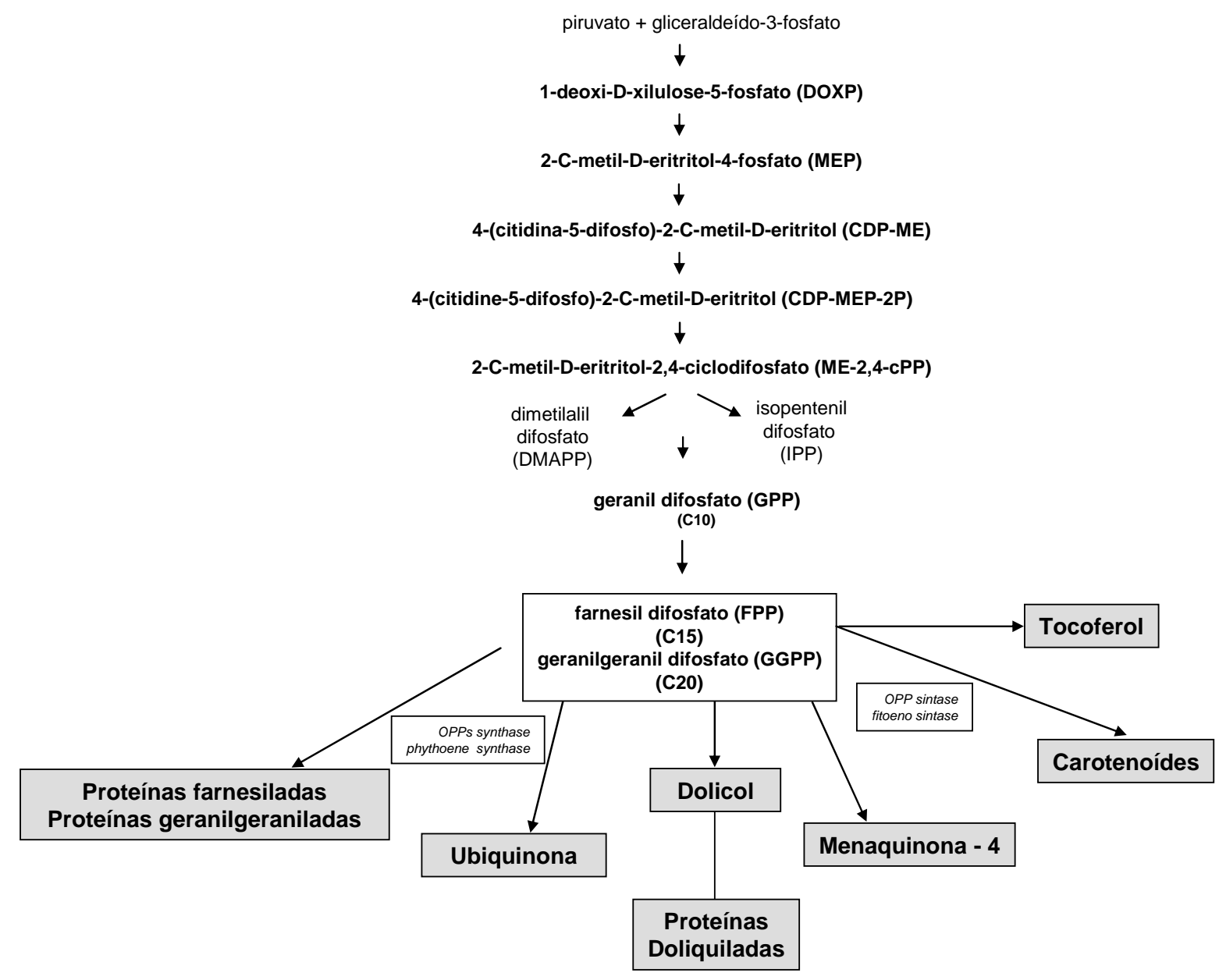

\subsection{Enzimas preniltransferases}

Preniltransferases, poliprenil difosfato sintase ou ainda isoprenil difosfato sintases são responsáveis por catalisar a condensação 1-4' do IPP com vários tipos de difosfatos alilícos, tais como, DMAPP (5 carbonos), GPP (10 carbonos), FPP (15 carbonos) e GGPP (20 carbonos) para formar o esqueleto de todos compostos isoprênicos, como caratenóides, ubiquinona, dolicol, entre outros.

Cada membro dessa família de enzima é classificado de acordo com a esterioquímica da dupla ligação formada durante o elongamento do produto e o tamanho do produto final. A especificidade do tamanho da cadeia dos isoprenóides individuais são responsáveis pela especificidade do produto da preniltransferase correspondente. Em geral, as transpreniltransferases sintetizam produtos de tamanho de até 50 carbonos, com trans (E) dupla ligação, enquanto as cis-preniltransferases são caracterizadas por gerar produtos mais longos com cis $(\mathrm{Z})$ dupla ligação. A denominação $(\mathrm{E}) /(\mathrm{Z})$ refere-se a estereoquímica cis ou trans da 
dupla ligação, para (E), os átomos de carbono estão em lados opostos (trans), na dupla ligação. Para (Z), os átomos de carbonos estão no mesmo lado (cis).

Embora trans- e cis- preniltransferases catalizam semelhantes reações, elas são evolutivamente e estruturalmente distintas. Trans-preniltransferases podem ser novamente divididas em preniltransferases de cadeia curta (C10-C25), cadeia média (C30-C35) e cadeia longa (C40-C50). Em muitos organismos as prenil sintases de cadeia curta GPP, FPP e GGPP elonga o DMAPP para produtos de C10, C15 e C20 respectivamente.

Tipicamente, organismos diferentes têm diferentes preniltransferases para sintetizar os isoprenoídes difosfatos necessários em inúmeros processos metabólicos. Embora humanos tenham duas distintas enzimas monofuncionais para produzir FPP e GGPP, este não é o caso de todos organimos. Por exemplo, Metanobacteria termoautotrófica e T. gondi tem uma única enzima capaz de produzir FPP e GGPP (Chen, Poulter, 1993; Fujiwara et al., 2004; Ling et al., 2007), enquanto Mizus persicae tem uma única enzima com atividade de GPPS e FPPS (Vandermoten et al., 2008), Picea abies também possui uma outra enzima bifuncional com atividade de GPPS e GGPPS (Schmidt et al., 2010). T. cruzi possui uma única enzima a FPPS com o FPP como produto (Montalvetti et al., 2001). Diversas preniltransferases tem sido descritas em vários organismos dos três reinos, eucariontes, bactérias e arquae, no entanto, FPPS e GGPPS são as preniltransferases mais estudadas.

\subsection{Farnesil difosfato sintase e geranilgeranil difosfato sintase}

A enzima FPPS catalisa a condensação consecutiva de IPP com DMAPP para formar o intermediário GPP que em uma segunda etapa forma o composto isoprênico de 15 carbonos FPP. O FPP é um intermediário presente no ponto de ramificação da via de isoprenoídes e pode ser substrato para a síntese de diversos compostos isoprênicos, como ubiquinonas, carotenóides, dolicóis e unidades isoprênicas ligadas às proteínas; como também pode ser condensado com uma molécula adicional de IPP pela enzima geranilgeranil pirofosfato sintase (GGPPS) para formar o isoprenóide de 20 carbonos, o GGPP. O GGPP é também essencial na isoprenilação de proteínas e precursor para a biossítese de carotenóides.

Nos últimos anos, diversos estudos têm sido realizados utilizando experimentos de mutação sítio-direcionada e cristalografia para determinação do modo de ligação do substrato e a catálise da enzima. A primeira estrutura cristal de uma preniltransferase relatada foi de uma FPPS aviária (Tarshis et al., 1994). FPPS é um homodímero, e o sítio catalítico de ambas as unidades consiste em uma alfa-helice antiparalela, com duas regiões ricas em aspartato, 
denominada primeiro motivo rico em aspartato (FARM) e o segundo motivo rico em aspartato (SARM), que se encontram presentes nas regiões conservada II e VI, respectivamente. Comparando as seqüências de diversas peniltransferases todas apresentam sete regiões conservadas incluindo os dois domínios característicos, FARM e SARM que são cruciais para a ação catalítica da enzima e sítio para a ligação dos substratos (Gabelli et al., 2006). Diversos estudos têm mostrado que resíduos conservados de aspartato no domínio II da FPPS são cruciais para a eficiência catalítica da enzima, e que o substrato se liga a resíduos de aspartato do FARM através do $\mathrm{Mg}^{2+}$. FARM e SARM estão criticamente envolvidos na conversão química de IPP e GPP para FPP e/ou na liberação do produto FPP a partir da enzima.

Estudos de cristalografia mostraram que a $4^{\circ}$ e $5^{\circ}$ posição $\mathrm{N}$-terminal antes da região FARM, conhecida como região CLD (determinação do tamanho da cadeia) tem uma função crucial para a determinação do tamanho do último produto nas reações catalisadas pela FPPS (Ohnuma et al., 1996b). E também sugere que o tamanho do produto final é influenciado pelo tamanho da bolsa hidrofóbica no interior da enzima que liga a cadeia de hidrocarboneto (Wang, Ohnuma, 1999). Usualmente quando se tem combinação de dois aminoácidos aromáticos como fenilanina e tirosina para formar a bolsa hidrofóbica no interior da enzima que vai se ligar o hidrocarboneto, o produto da FPPS é o FPP. Isto aparentemente ocorre porque aminoácidos volumosos (fenilanina e tirosina) podem bloquear a nova condensação de compostos maiores que 15 carbonos.

Estudos usando mutagenese química aleatória destinada a alterar a seletividade do tamanho da cadeia das preniltranseferases, tem mostrado que a FPPS de Baccillus stearotermofilus pode ser convertida numa GGPPS pela simples substituição de um aminoácido, tirosina 81 da FPPS, situada na $5^{\circ}$ posição anterior ao dominio FARM (Ohnuma et al., 1996a; Ohnuma et al., 1996b). Resultados semelhantes foram demonstrados com a AvFPPS, que mostraram que mutação na fenilanina 112 localizadas na $5^{\circ}$ posição antes do domínio FARM por alanina também se detecta a formação de GGPP (Tarshis et al., 1996). A substituição de aminoácidos com anéis aromáticos por aminoácidos menores leva a formação de produtos com tamanho da cadeia maior que o normal sugerindo que a região próxima do FARM determina a especificidade do produto da FPPS e GGPPS (Gabelli et al., 2006).

Existem três possíveis padrões para o tipo de aminoácido presente na $4^{\circ}$ e $5^{\circ}$ posição antes do domínio FARM, por exemplo, (FPPS tipo I) tem dois aminoácidos aromáticos na $4^{\circ}$ e $5^{\circ}$ posição anterior ao FARM, GGPPS tipo II e tipo III têm um aminoácido aromático na $5^{\circ}$ posição e um pequeno aminoácido na $4^{\circ}$ posição antes do FARM, FPPS tipo II e GGPPS tipo 
I e prenil sintase de cadeia longa, possuem apenas um aminoácido aromático na $5^{\circ}$ posição antes do FARM.

No entanto quando Li et. al. (2012) compararam a região CLD da enzima FPPS bifuncional de T. gondii com outras FPPS e GGPPS, encontraram algumas diferenças interessantes. O $4^{\circ}$ aminoácido antes do FARM é uma fenilanina um aminoácido com tamanho da cadeia volumoso, e na posição do $5^{\circ}$ aminoacido antes da região FARM tem-se uma cisteína (Ling et al., 2007). Na tentativa de verificar se esta combinação incomum no $4^{\circ} \mathrm{e}$ $5^{\circ}$ aminoácido poderia fornecer a enzima uma característica não usual de bifuncionalidade capaz de produzir FPP e GGPP como produtos, experimentos de mutação foram realizados e demonstrou-se que a cisteína na $4^{\circ}$ posição é essencial para a bifuncionalidade da FPPS de $T$. gondi (Li et al., 2012).

Embora FPPS e GGPPS produzam produtos finais distintos, elas possuem seqüências e propriedades enzimáticas semelhantes. Análises filogenéticas classificaram as GGPPS em GGPPS tipo I, que inclui as arqueas, GGPPS tipo II onde estão incluídas as eubactérias e plantas e levedura e mamíferos pertencem a GPPSS tipo III. As FPPS podem ser divididas em dois tipos, tipo I (eucarionte) e tipo II (eubacteria). Análises filogenéticas da FFPS de T. gondi mostraram que ela se encaixa com outras FPPS tipo I, mas os dados bioquímicos sugerem que ela tem uma característica única que a diferência de outras FPPS e GGPS, sendo, portanto um importante alvo de drogas (Li et al., 2012).

Os genes que codificam a proteína FPPS foram clonados em diversos protozoários como T. cruzi (Montalvetti et al., 2001), T. brucei (Montalvetti et al., 2003), e L. major além da FPPS de T. gondii (Ling et al., 2007). Em P. falciparum nosso grupo caracterizou pela primeira vez a presença de uma preniltransferase a octaprenil difosfato sintase (OPPS) (Tonhosolo et al., 2005) e, mais recentemente mostrou a bifuncionalidade dessa enzima como uma fitoeno sintase, capaz de formar fitoeno, o primeiro intermediário da biossíntese de carotenóides (Tonhosolo et al., 2009). Recentemente, GGPPS de P. vivax foi clonada, expressada, purificada e sua estrutura tridimensional determinada (Artz et al., 2011). Uma prenil sintase não específica foi demostrada em Criptosporidum parvum (Artz et al., 2008).

Além de demonstrarem a funcionalidade das FPPS, a sua localização também é estudada. Em mamíferos e plantas a FPPS podem estar localizada em diferentes compartimentos semelhante a outras poliprenil sintases. Por exemplo, a FPPS pode ter sido encontrada no citosol e associada com o retículo endoplasmático (Hugueney et al., 1996), mitocôndria (Cunillera et al., 1997), e plastídeos em plantas (Sanmiya et al., 1999) e peroxissomas em animais (Biardi, Krisans, 1996). Em T. gondii a localização mitocondrial foi 
determinada (Ling et al., 2007). Os tripanossomatídeos T. cruzi e T. brucei apresentaram localização citosólica da FPPS (Ferella et al., 2008), resultados semelhantes aos de L. major (Ferella et al., 2008; Ortiz-Gomez et al., 2006). Em T. brucei experimentos utilizando a técnica de interferência de RNA (RNAi) silenciando o gene, mostram que FPPS é realmente um componente celular essencial para a sobrevivência do parasita (Montalvetti et al., 2003), assim como sugerido para outros organismos (Blanchard, Karst, 1993; Song, Poulter, 1994). Diversos trabalhos demonstraram que FPPS e GGPPS são possíveis alvos dos bisfosfonatos, além disso, estudos de cristalografia dessas enzimas estão sendo realizados em humanos, $P$. vixax e T. cruzi complementando os estudos anteriores de que cada vez mais essas enzimas poderão ser exploradas como potenciais alvos de drogas.

\subsection{Bisfosfonatos}

Bisfosfonatos (BFs) são análogos sintéticos do pirofosfato, onde na estutura do composto P-O-P tem a substituição do O pelo C. Bisfosfonatos são potentes inibidores da reabsorção óssea e são utilizados para o tratamento e prevenção da osteoporose, doença de Paget, hipercalcemia causada por tumor ósseo e outras doenças ósseas (Rodan, 1998). Bisfosfonatos também tem se mostrado promissores como drogas antibacterianas, anticâncer e antiparasitárias (Docampo, Moreno, 2001; Rohmer et al., 2004; Stresing et al., 2007).

Bisfosfonatos apresentam em sua estrutura química dois grupamentos fosfato $\left(\mathrm{PO}_{3}=\right)$ ligados covalentemente a um carbono central, acrescidos de duas cadeias denominadas genericamente de R1 e R2. A primeira cadeia, curta, é responsável pelas propriedades químicas e farmacocinéticas dos BFs, além de conferir, em conjunto com os grupamentos fosfato, alta afinidade ao tecido ósseo. Já a cadeia longa R2 determina a potência antireabsortiva e o mecanismo de ação farmacológico. Contudo, ambas as cadeias são de suma importância para a efetividade destes medicamentos (Russell et al., 2008).

Figura 7- Estrutura dos bisfosfonatos.

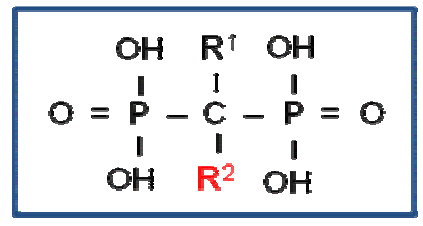


Os bisfosfonatos apresentam, basicamente, duas categorias de estrutura química da cadeia R2, que são os não-nitrogenados e os BFs-nitrogenados (BFs-N). Os bifosfonatos nãonitrogenados podem ser metabolicamente incorporados em análogos não hidrolizados de ATP que acumulam intracelularmente nos osteoclastos, resultando na indução da apoptose no osteoclasto. Em contraste, a classe mais potente de drogas são os BPs-N, como risedronato, alendronato e pamidronato, onde trabalhos recentes demonstraram que os BPs-N possuem como alvo a via do mevalonato e mais especificamente a enzima FPPS (Rogers et al., 1999).

A inibição da enzima FPPS por BFs-N, impede a formação de isoprenóides intermediários essenciais como FPP e GGPP, que são necessários para a isoprenilação de pequenas GTPases, semelhantes a Ras, Rho, Rac e proteínas da família Rab nos osteoclastos (Maltese, 1990). Bisfosfonatos inibem a reabsorção óssea por mecanismos que levam a apoptose de osteoclastos (Coxon et al., 2000). A inibição da prenilação das proteínas por bisfosfonatos em macrófagos J774 in vitro já foi demonstrada (Luckman et al., 1998). A inibição de rap1A por bisfosfonatos foi demonstrada em diversas culturas de células, incluindo osteoclastos, osteoblastos, macrófagos, células epiteliais e endoteliais, em mieloma e células tumorais da próstata (Roelofs et al., 2006). A inibição da FPPS também resulta na acumulação do substrato IPP, que pode ser convertido no éster isopentenil ATP (ApppI) que é altamente pró-apoptótico e contribui para a eficácia dos bisfosfonatos in vitro e in vivo (Reszka et al., 2001).

O exato mecanismo de inibição da FPPS por BPs-N está cada dia se tornando mais clara. A recente geração de estrutura da enzima FPPS humana, cocristalizada com risedronato e zolendrônico, revelou que BPs-N se ligam ao sítio de ligação do GPP na enzima, com interações estabilizantes que ocorem entre a porção do nitrogênio do BP-N e um conservado resíduo treonina e lisina da enzima. Análises cinéticas com a enzima FPPS humana indicam que a interação com BFs-N é altamente complexa e caracterizada por uma inibição considerada de "forte ligação". Inicialmente BFs-N parece competir diretamente com DMAPP ou GPP por se ligar na bolsa de ligação do DMAPP/GPP. Isto é seguido por uma interação mais complexa que promove ligação do IPP no segundo sítio de ligação do isoprenoíde na enzima, causando mudanças conformacionais que estabilizam o complexo terciário final, ajudando a explicar a extraordinária potência inibitória de alguns BPs-N para esta enzima. 
Figura 8- Via de síntese dos compostos isoprênicos caracterizados em P. falciparum. E a inibição da enzima FPPS por bisfosfonatos.

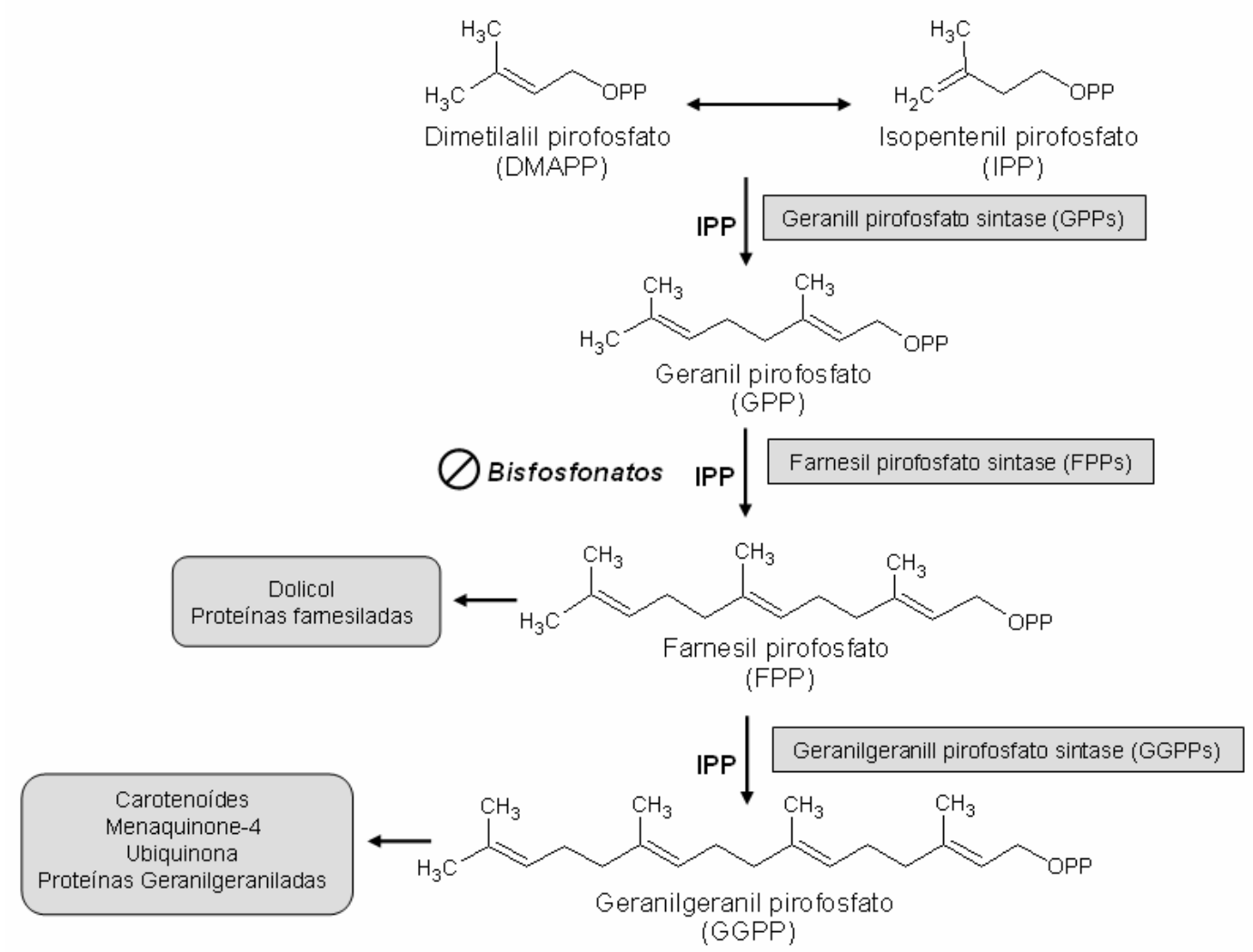

Estes estudos estão começando a fornecer informações importantes, e revelou-se que pequenas modificações na estrutura e conformação do $\mathrm{R}_{2}$ da cadeia lateral dos bifosfonatos (conhecidos por afetar a potência da reabsorção óssea e também por afetar a abilidade de inibir a FPPS) podendo tornar esses compostos mais eficazes (Russell et al., 2008).

Novos estudos demostraram a potente atividade in vivo e in vitro de uma nova classe de bifosfonatos, os bisfosfonatos lipofílicos, onde o grupo-OH é removido e uma cauda lipofílica é adicionada. Estes bifosfonatos lipofílicos possuem mais atividade que os bifosfonatos convencionais na inibição no crescimento de células tumorais in vitro e in vivo.

\subsection{Bisfosfonatos contra protozoários}

Bisfosfonatos inibem o crescimento in vitro de uma variedade de parasitas, incluindo T. gondii, T. brucei, T. cruzi, Leishmania ssp., Entamoeba histolitica, Cripstosporidium parvum e $P$. falciparum, confirmando a atividade antiparasitária desses compostos (Martin et 
al., 2001; Sanders et al., 2003). Testes in vivo, em camundongos infectados com T. gondii, mostraram que risedronato aumenta significativamente a sobrevida dos camundongos infectados com T. gondii (Yardley et al., 2002) e resultados similares foram demonstrados em camundongos infectados com P. berghei (Singh et al., 2010). BFs-N também foram efetivos na inibição do crescimento e desenvolvimento de T. cruzi in vitro e in vivo, sem causar toxicidade na célula hospedeira(Urbina et al., 1999).

Os valores de $\mathrm{IC}_{50}$ para 26 bisfosfonatos contra a recombinante de PvGGPPS foram determinados e comparou-se os resultados de inibição da enzima com os valores de inibição do crescimento dos estágios intraeritrocitários de $P$. falciparum e uma pobre correlação foi observada (Mukkamala et al., 2008). Culturas de plasmódio tem sido consideradas menos sensíveis aos BPs-N que os kinetoplastídeos, Toxoplasma e Criptosporídio, acredita-se que um dos problemas esteja relacionado com o transporte da droga, resultado de uma rápida eliminção na circulação sanguínea, uma característica natural de drogas ósseas. Assim novos compostos podem permanecer viáveis como candidatos antimaláricos, eliminando os problemas de permeabilidade na célula descritos no passado e melhorando o sistema de transporte das drogas.

Assim, bisfosfonatos lipofílicos que bloqueiam as prenil sintases FPPS e GGPPS, que mostraram anteriormente com atividade in vitro e in vivo quando comparados com os convencionais bisfofonatos na inibição do crescimento de células tumorais e ensaios de ativação de células $\mathrm{T}$ e apresentaram atividade contra os estágios hepáticos do Plasmódio (Singh et al., 2010). Recentemente mostrou-se que análogos lipofílicos do bisfofonatos comerciais ácido zolendrônico e risedronato, BPH-703 e BPH-811 respectivamente, foram às drogas mais potentes, de uma biblioteca de 560 inibidores da prenil transferases, testados contra os estágios intraeritrocíticos de $P$. falciparum. Neste mesmo trabalho, os autores determinaram a estrutura cristal da GGPPS de P. vivax com estes compostos e também testaram ambos compostos em camundongo observando uma diminuição na parasitemia e uma sobrevida de 100\% (No et al., 2012).

\subsection{Justificativas e objetivos}

$\mathrm{Na}$ última década, a biossíntese de isoprenóides tem sido apontada como um importante alvo para o desenvolvimento de novos quimioterápicos contra os parasitos causadores da malária humana. Esse fato se deve à importância dos produtos derivados dessa via para o metabolismo de qualquer célula eucariótica e, principalmente, ao fato da via de 
biossíntese de isoprenóides no plasmódio (via MEP) ser diferente da existente em seu hospedeiro vertebrado (via do mevalonato). Recentemente demonstrou-se que o apicoplasto tem como principal função a presença da via de biossíntese de isoprenóides.

No estudo dessa via de biossíntese como potencial alvo quimioterápico, diferentes pontos têm sido abordados. A inibição do metabolismo primário, de isoprenóides pela inibição direta das enzimas presentes na via MEP, com drogas como a fosmidomicina, tem se mostrado uma área promissora, com testes clínicos em humanos já realizados. Outra abordagem visa à inibição do metabolismo secundário de isoprenóides, tentando inibir a elongação da cadeia de compostos isoprênicos ou inibir a ligação desses compostos a proteínas.

Como já mostrado anteriormente, BPs-N são potentes inibidores da FPPS (Kavanagh et al., 2006), capazes de inibir a isoprenilação de proteínas em osteoclastos, macrófagos, células epiteliais e endoteliais e mieloma, e também apresentam atividade antibactericida e antiparasitária. $\mathrm{O}$ efeito de uma série de bisfosfonatos foi testado in vitro, sobre o crescimento de T. gondii, T. brucei rhodesiense, L. donovani, e P. falciparum, e foi visto que vários bisfosfonatos podem efetivamente inibir o crescimento destes parasitas. Em Plasmodium diversos estudos estão sendo realizados para verificar o efeito dos bisfosfonatos e mais recentemente uma nova geração de bisfosfonatos denominados bisfosfonatos lipofílicos, que apresentaram atividade in vitro e in vivo em $P$. falciparum, além de mostrarem que esses compostos podem inibir a enzima GGPPS de P. vivax. Sabendo-se dessas informações e, que a prenilação de proteínas acontece em $P$. falciparum e outros parasitas, bisfosfonatos são considerados promissores candidatos a drogas para o tratamento de infecções causadas por $P$. falciparum e outros parasitas protozoários.

Como foi mencionado anteriormente a enzima FPPS biossintetiza FPP a partir de IPP e DMAPP, sendo esta reação considerada um passo importante na via de isoprenóides, pois FPP é substrato para diversos produtos secundários da via de isoprenóides que são essenciais para a sobrevida do parasita. Em $P$. falciparum $\left[1-{ }^{3} \mathrm{H}\right] \mathrm{FPP}$ e $\left[1-{ }^{3} \mathrm{H}\right] \mathrm{GGPP}$ foram utilizados como precusores para a caracterização de diversos compostos isoprênicos presentes no parasita como: dolicol, ubiquinona, menaquinona-4, carotenoides, farnesilação e geranilgeranilação de proteínas (Jordao et al., 2011). Até o momento a FPPS de P. falciparum ainda não foi caracterizada e, por se tratar de uma enzima considerada um importante alvo para desenvolvimento de drogas antimaláricas, onde alterações na enzima FPPS alteraria o fluxo de biossíntese de todos esses compostos presentes no parasita, levando a uma desrregulação na maquinária do parasita, incluindo a inibição da isoprenilação de proteína. 
Com base nas informações acima os objetivos dessa tese foram:

I) verificar o mecanismo de ação do risedronato, no ciclo intraeritrocitário de $P$. falciparum;

II) caracterização da enzima Farnesil difofosfato sintase (FPPS) de P. falciparum. 
2 MATERIAIS E MÉTODOS 


\subsection{Cultivo de $P$. falciparum in vitro}

A cepa 3D7 de P. falciparum foi cultivada de acordo com o método de Trager e Jensen (Trager, Jensen, 1976) substituindo o soro humano por Albumax I (0.5\%, Invitrogen) (Kimura et al., 1996). Os parasitas foram cultivados em garrafas de cultivo com meio RPMI1640 suplementado com Hepes $25 \mathrm{mM}$, bicarbonato de sódio $21 \mathrm{mM}$, hipoxantina $300 \mathrm{mM}$, glicose $11 \mathrm{mM}$ e gentamicina $40 \mathrm{~g} / \mathrm{ml}$. Eritrócitos foram adicionados à cultura obtendo um hematócrito de $5 \%$. As garrafas foram mantidas em estufa a $37{ }^{\circ} \mathrm{C}$ com trocas diárias de meio e injeção de uma mistura gasosa composta por 5,05\% $\mathrm{CO}_{2}, 4,93 \% \mathrm{O}_{2}$ e $90,2 \% \mathrm{~N}_{2}$. O controle da parasitemia foi realizado com a verificação microscópica diária de esfregaços corados com Giemsa.

\subsection{Separação e purificação dos estágios intraeritrocitários de $P$. falciparum}

Para obtenção dos três estágios parasitário de P. falciparum - anel (trofozoíta jovem), trofozoíta maduro e esquizonte - os parasitas foram purificados por um gradiente descontínuo de Percoll $^{\circledR}$ (Pharmacia Chemicals, Uppsala, Sweden) 40/70/80\% (Braun-Breton et al., 1986). Pellet de cultura foi adicionado em tubos de vidro Corex (Du Pont ${ }^{\mathrm{TM}}$, USA) contendo 2, 4 e 3 $\mathrm{ml}$ das soluções de $\operatorname{Percoll}^{\circledR}$ de 80,70 e $40 \%$, respectivamente, e centrifugados a $10.000 \times \mathrm{g}$ por $30 \mathrm{~min}$ a $25{ }^{\circ} \mathrm{C}$. Nessas condições as formas esquizontes ficaram na fração $40 \%$, trofozoítas entre 70 e $80 \%$ e anéis e hemácias não infectadas na fração de $80 \%$. Os parasitos foram então coletados e lavados 3x com PBS. Após a lavagem os parasitos, no estágio de anel, foram liberados dos eritrócitos por uma lise com saponina $0,1 \%(\mathrm{p} / \mathrm{v})$. O volume dos pellets de cada estágio foi então medido e as proteínas extraídas.

Os parasitas no estágio de esquizonte foram purificados por uma coluna de separação magnética (MACS-Coluna de Separação-“CS”) (Trang et al., 2004). As etapas de préequilibração, lavagem e eluição da coluna foram realizadas com RPMI-1640 a temperatura ambiente. Para a purificação dos esquizontes, a cultura foi centrifugada a $2000 \mathrm{x} g$ por $5 \mathrm{~min}$, o pellet contendo eritrócitos parasitados e eritrócitos - não parasitados foi ressuspendido em RMPI-1640 (1:10 v/v), $10 \mathrm{ml}$ da suspensão $10 \%$ de eritrócitos foi adicionado à coluna CS fixada ao campo magnético. Somente parasitas no estágio de esquizontes ficaram retidos na coluna. A coluna ainda fixada foi lavada com $50 \mathrm{ml}$ de RPMI-1640, e em seguida removida, e seu conteúdo eluido com $50 \mathrm{ml}$ de RPMI-1640. Os parasitas no estágio de esquizonte eluidos 
foram centrifugados a $2000 \mathrm{x} \mathrm{g}$ por $5 \mathrm{~min}$, a temperatura ambiente. O sobrenadante foi descartado e o pellet de parasitas foi armazenado em $\mathrm{N}_{2}$ para posterior análise.

\subsection{Teste de inibição com risedronato e ensaio de recuperação}

Risedronato foi dissolvido em água deionizada estéril, resultando em uma solução estoque de $25 \mathrm{mM}$. O teste de inibição foi realizado com placas de titulação de fundo plano, utilizando-se as seguintes concentrações de droga: 3.000, 300, 30, 3, 0,3, 0,03, e 0,003 $\mu \mathrm{M}$. Para determinar a concentração inibitória de 50\% ( $\left.\mathrm{IC}_{50}\right)$ do risedronato nos estágios intraeritrocitários de $P$. falciparum após 48 h de tratamento, foi utilizado um método descrito anteriormente por Desjardins et al (1979), com algumas modificações (Desjardins et al., 1979). Culturas sincrônicas de parasitas no estágio de anel (5\% de hematócrito e parasitemia $1 \%$ ) foram expostas a crescentes concentrações da droga, e a parasitemia e morfologia dos parasitas foi determinada já na primeira hora e em intervalos de 24 a 96 h com esfregaços corados com Giemsa. Todos os testes foram realizados em triplicada para os três independentes experimentos. $\mathrm{A} \mathrm{IC}_{50}, \mathrm{IC}_{90}$ ( \pm desvio padrão), e intervalo de confiança de $95 \%$ (IC95\%) para valores de inibição de crescimento foram calculados usando o software Origin 8.1 (Origin).

Para os ensaios de recuperação, FPP, GGPP e IPP foram solubilizados em meio RPMI-1640 (solução estoque de $5 \mathrm{mM}$ ) e diferentes concentrações de cada composto (100 $\mathrm{nM}$ a $1.000 \mathrm{nM}$ ) foram então adicionados simultaneamente às culturas sincrônicas de $P$. falciparum em fase de anel previamente tratados com $20 \mu \mathrm{M}$ de risedronato. A parasitemia foi avaliada a cada $24 \mathrm{~h}$. A análise estatística foi realizada usando a análise de variância (ANOVA) seguida pelo teste de Dunnett post hoc (GraphPad Prism, CA). Um valor de p $<0,05$ foi considerado estatisticamente significante.

\subsection{Tratamento com risedronato e marcação metabólica}

Culturas assincrônicas de P. falciparum foram tratadas com $15 \mu \mathrm{M}$ de risedronato por $36 \mathrm{~h}$ e marcados com $\left[1-{ }^{3} \mathrm{H}\right] \mathrm{GGPP}$ ou $\left[1-{ }^{3} \mathrm{H}\right] \mathrm{FPP}(3.125 \mu \mathrm{Ci} / \mathrm{ml}$, Amershan GE, healthcare Life Sciences) nas últimas $12 \mathrm{~h}$ na presença da droga. Após a marcação anel, trofozoíto e esquizonte foram purificados por Percoll ${ }^{\circledR}$ e a lise das células foi realizada utilizando uma solução gelada de Tris-HCl 10 mM pH 7.2, NaCl 150 mM, 2\% Triton X-100 (vol/vol), fenilmetilsulfonil fluorido (PMSF) $0,2 \mathrm{mM}$, iodoacetamida $5 \mathrm{mM}, N$-(p-tosil-lisina) 
clorometil cetona $1 \mathrm{mM}$, e leupeptina $1 \mu \mathrm{g} / \mathrm{ml}$, (TEN-Triton) incubados por $15 \mathrm{~min}$ a $4{ }^{\circ} \mathrm{C}$, após, foram centrifugados a $10.000 \times \mathrm{g}$ a $4{ }^{\circ} \mathrm{C}$ por $10 \mathrm{~min}$. O sobrenadante dos parasitas foi posteriormente analisado por SDS-PAGE.

Para análise de isoprenóides, culturas sincrônicas na fase de anel foram tratadas com $15 \mu \mathrm{M}$ de risedronato durante $36 \mathrm{~h}$, e marcadas metabolicamente com $\left[1-{ }^{14} \mathrm{C}\right] \mathrm{IPP}(1,25$ $\mu \mathrm{Ci} / \mathrm{ml}$ ) pelas últimas $12 \mathrm{~h}$. Após a marcação, parasitas no estágio de esquizonte foram purificados pela coluna CS. O pellet dos parasitas foi armazenado em $\mathrm{N}_{2}$ para posterior análise por TLC.

Risedronato $15 \mu \mathrm{M}$ foi considerada a concentração da droga ideal para ser utilizada em nossos experimentos de marcação metabólica, uma vez que aproximadamente $90 \%$ da população de parasitas permaneceram viáveis após $36 \mathrm{~h}$ de tratamento.

\subsection{Cromatografia de alta performance fase -reversa (RP-TLC)}

Quantidades similares de pellet de parasitas no estágio de esquizonte tratados ou não tratados marcados com $\left[1-{ }^{14} \mathrm{C}\right] \mathrm{IPP}$ como descrito acima, foram extraídos com hexano e subseqüentemente os alcoóis foram separados em uma placa sílica gel 60 fase reversa (Merck) com acetona: $\mathrm{H}_{2} \mathrm{O}\left(6: 1\right.$, vol/vol) ref. As placas foram espraiadas com $\mathrm{En}^{3} \mathrm{Hance}$ (DuPont NEN) e submetidas a autoradiografia por 45 dias a $-70^{\circ} \mathrm{C}$. A posição dos padrões dos prenil alcoóis padrões foi visualizada com vapor de iodo e a radioatividade visualizada por autoradiografia. Os valores de $R_{f}$ de ambos foram determinados. Extrato de hexano de eritrócitos não infectados foi utilizado como controle.

\subsection{Eletroforese em gel de poliacrilamida}

SDS-PAGE foi realizado em uma concentração de poliacrilamida 12,5\% (Laemmli, 1970). Quantidades similares de parasitas no estágio de esquizonte tratados ou não tratados marcados com $\left[1-{ }^{3} \mathrm{H}\right] \mathrm{GGPP}$ ou $\left[1-{ }^{3} \mathrm{H}\right] \mathrm{FPP}$ como descrito acima, tiveram suas proteínas extraídas com TEN-Triton e posteriormente solubilizados em tampão de amostra SDS (Tris$\mathrm{HCl} 50 \mathrm{mM}$ pH 6,8, ditiotreitol $100 \mathrm{mM}$, SDS 2\%, azul de bromofenol 0,1\% e glicerol 10\%) e aplicado sobre cada poço para análises das proteínas isopreniladas. Todos os géis foram incubados com Amplify (Amersham), secos e expostos a filme Kodak X-Omat a $-70{ }^{\circ} \mathrm{C}$ durante 30 dias e posteriomente revelados. 


\subsection{Imunoprecipitações}

Culturas sincrônicas no estágio de anel foram tratados com $15 \mu \mathrm{M}$ de risedronato e marcadas metabolicamente com $\left[1-{ }^{3} \mathrm{H}\right] \mathrm{FPP}$ ou $\left[1-{ }^{3} \mathrm{H}\right] \mathrm{GGPP}$, como descrito acima. Parasitas no estágio de esquizonte foram ressuspensos no tampão de imunoprecipitação (Tris- $\mathrm{HCl} 50$ $\mathrm{mM}, \mathrm{pH} 8,0, \mathrm{NaCl} 150 \mathrm{mM}, 1 \%$ [vol/vol] Triton X-100, 0,5\% [peso/vol] desoxicolato de sódio, 0,1\% [peso/vol] SDS, coquetel de inibidores de protease $5 \mathrm{ug} / \mathrm{ml}$ [fluoreto de fenilmetilsulfonilo $0,2 \mathrm{mM}$, benzamidina $1 \mathrm{mM}, \beta$-mercaptoetanol $2 \mathrm{mM}$, quimostatina 5 $\mathrm{mg} / \mathrm{ml}$, e $1 \mathrm{ug} / \mathrm{ml}$ de leupeptina, antipaína, e pepstatina A]) e, em seguida, pre-clarificada com proteína A-Sepharose (GE Healthcare) (Moura et al., 2001). Após incubados com as imunoglobulinas monoclonais anti-humano Ras ou anti-Rap1/Krev-1 (diluição de 1:20; tecnologia de sinalização celular) durante $2 \mathrm{~h}$, a $4{ }^{\circ} \mathrm{C}$. O complexo antígeno-anticorpo foi precipitado usando $100 \mu \mathrm{l}$ da suspensão $10 \%$ de proteína A-Sepharose. Após cinco lavagens com PBS, o antígeno ligado foi liberado e resuspenso no tampão de amostra SDS e analisados por SDS-PAGE. Os géis foram incubados com Amplify (Amersham), secos e expostos a filme Kodak X-Omat a $-70{ }^{\circ} \mathrm{C}$ durante 30 dias e posteriomente revelados. Análises densitométricas foram realizadas usando o sofware Image J (National Institutes of Health).

\subsection{Escolha da seqüência e alinhamento da Pf11-0295 com a FPPS de outros organismos}

A seqüência de nucleotídeos (Pf11_0295) do gene que codifica a possível Farnesil pirofosfato sintase (FPPs) de P. falciparum foi obtida na base de dados Plasmo DB e o alinhamento das seqüências de nucleotídeos foi realizado utilizando o software Clustal W.

\subsection{Amplificação por PCR}

O fragmento de $1131 \mathrm{bp}$ do gene PfFPPS (PlasmoDB ID Pf11-0295) foi amplificado usando os oligonucleotideos (Invitrogen) PfFPPS1 CCGGATCCATGGAGAACGAGCAGAATAAC-3') e PfFPPS2 (5'CGGAATTCTCAAGCGCCTGTAAACAAAATGTC-3') usando cDNA contendo parasitas nos três estágios (anel, trofozoíto e esquizontes). As condições de PCR foram: 10 ciclos de 94 ${ }^{\circ} \mathrm{C}$ por $40 \mathrm{~s}, 48{ }^{\circ} \mathrm{C}$ por $40 \mathrm{~s}$, e 25 cilos a $94{ }^{\circ} \mathrm{C}$ por $40 \mathrm{~s}, 54{ }^{\circ} \mathrm{C}$ por $40 \mathrm{~s}, 72{ }^{\circ} \mathrm{C}$ por $1,30 \mathrm{~min}$, usando 2,5 unidades de DNA polimerase e cDNA como template, 200 pmol de cada um dos dois primers, $1 \mu$ tampão, e $0.2 \mathrm{mM}$ dNTPs em um volume total de $50 \mu 1$. O produto 
amplificado foi submetido a eletroforese em gel de agarose $1 \%$. O produto seqüenciado e posteriormente purificado com silica Glass Milk. (Vogelstein, Gillespie, 1979).

\subsection{Expressão e purificação da rPfFPPS de $E$. coli}

A recombinante pGEX-2T-FPPs foi usada para transformar E. coli BL21DE3 plys RIL. Clones bacterianos foram cultivados em meio LB contendo ampicilina $50 \mu \mathrm{g} / \mathrm{ml} \mathrm{e}$ clorafenicol $34 \mu \mathrm{g} / \mathrm{ml}$ em caldo Luria (Hi-media) a $37{ }^{\circ} \mathrm{C}$ ate DO600 de 0,6 . Neste momento a expressão da recombinante PfFPPS foi induzida com $0,2 \mu \mathrm{M}$ de isopropanol $\beta$-Dtiogalactósido a $24{ }^{\circ} \mathrm{C}$, over-night. As células foram sedimentadas por centrifugação e ressuspensas em tampão de lise PBS/0.1\% (v / v) de Triton X-100 a pH 7,2, lisozima 0,05 $\mathrm{mg} / \mathrm{ml}$ e PMSF 0,2 mM. A lise foi concluída por sonicação (cinco pulsos de $30 \mathrm{~s}$ em 40W, a 4 ${ }^{\circ} \mathrm{C}$ ). A proteína recombinante foi então purificada usando beads de glutationa Sepharose (GE Healthcare), seguindo as instruções do fabricante. A pureza da proteína foi verificada por SDS/PAGE (Laemmli, 1970) e quantificada pelo método de Bradford (Bradford, 1976).

\subsection{Ensaio de atividade enzimatica da rPfFPPS}

A atividade catalítica da rPfFPPS foi ensaiada medindo-se a conversão de $\left[4-{ }^{14} \mathrm{C}\right] \mathrm{IPP}$ $\left(56,6 \mathrm{mCi} / \mathrm{mmol}\right.$, Perkin Elmer Life sciences) em produtos $\left[{ }^{14} \mathrm{C}\right]$, por dois diferentes protocolos:

Protocolo I - O método descrito por Ling et al. (2007) foi utilizado com algumas modificações. O ensaio foi realizado em uma mistura contendo tampão Hepes $10 \mathrm{mM} \mathrm{pH} \mathrm{7,4,}$ $\mathrm{MgCl}_{2} 2 \mathrm{mM}$, ditiotreitol $2 \mathrm{mM},\left[4-{ }^{14} \mathrm{C}\right] \mathrm{IPP} 100 \mu \mathrm{M}$, substratos alélicos (DMAPP $100 \mu \mathrm{M}$, GPP $30 \mu \mathrm{M}$, ou FPP $15 \mu \mathrm{M}$ ), e 500-1000 ng da proteína recombinante num volume total de $100 \mu \mathrm{l}$. A reação foi realizada a $37^{\circ} \mathrm{C}$ durante $30 \mathrm{~min}$ e terminada pela adição de $10 \mu \mathrm{l}$ de HCl 6 M. A mistura da reação foi neutralizada por adição de $15 \mu 1$ de NaOH 6 M (Ling et al., 2007). Em seguida os produtos álcoois foram extraídos duas vezes com $500 \mu 1$ de hexano e analisadas por TLC. Todos os substratos não-radioativos e produtos químicos utilizados foram obtidos da SIGMA.

Protocolo II - a atividade da rPfFPPS foi realizada com o método descrito por Chang et al. (2006) com algumas modificações. As concentrações finais dos tampões do ensaio foram:

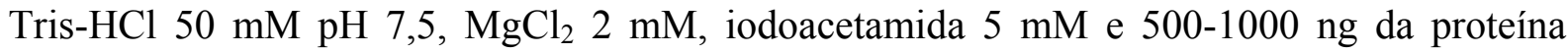
recombinante. As concentrações utilizadas dos substratos alílicos, DMAPP, GPP e FPP foram 
às mesmas já descritas anteriormente. O volume final da reação foi de $100 \mu$ l. Após préincubação a $37{ }^{\circ} \mathrm{C}$ durante $10 \mathrm{~min}$, a reação foi iniciada pela adição de $50 \mu \mathrm{M}\left[4-{ }^{14} \mathrm{C}\right] \mathrm{IPP}$. A mistura foi incubada a $37{ }^{\circ} \mathrm{C}$ durante $30 \mathrm{~min}$ e a reação terminada pela adição de água destilada saturada com $\mathrm{NaCl}$ (Chang et al., 2006). Os produtos difosfatos foram então extraídos duas vezes com $500 \mu \mathrm{l}$ de 1-butanol saturado com água saturada com $\mathrm{NaCl}$ e analisados por HPLC. Experimentos adicionais utilizando $\left[1-{ }^{3} \mathrm{H}\right] \mathrm{FPP}$ foram realizados seguindo esse protocolo.

\subsection{Identificação dos produtos da rPfFFPS}

Os produtos obtidos a partir do protocolo I foram analisados por cromatografia de camada fina (TLC) com uma placa fase reversa sílica Gel 60 (Merck) com acetona: $\mathrm{H}_{2} \mathrm{O}$ (6:1, v/v). A posição dos padrões prenil alcoóis foi visualizada usando vapor de iodo e a radioatividade visualizada por autoradiografia.

Os produtos fosforilados formados seguindo o protocolo II, foram analisados numa coluna Phenomenex Luna C18 (250 mm x 4,6 mm x $5 \mathrm{~mm}$ ) (Phenomenex, CA, EUA), acoplada com um C18 pré-coluna (Phenomenex, CA, EUA), um UV Gilson 152/UV detector de UV/visível variável a $214 \mathrm{~nm}$ e um colector de fracções FC203B. O software utilizado para processamento de dados foi o Sistema de Software UniPoint LC TM 3.0. O sistema de eluição

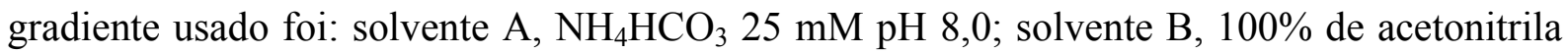
(v/v). Um gradiente linear foi realizado a partir de 0\% a 100\% B durante um período de 40 min, após $100 \%$ do B foi bombeado por $5 \mathrm{~min}$. As fracções foram recolhidas em intervalos de $1 \mathrm{ml} / \mathrm{min}$ (Zhang, Poulter, 1993). As fracções resultantes foram secas, ressuspensas em $500 \mu \mathrm{l}$ de líquido de cintilação (PerkinElmer Life Sciences) e monitoradas pelo contador de radiação, Beckman $5000 \beta$ de (Beckman, CA, EUA).

\subsection{Investigação por ESI-MS/MS dos produtos GOH, FOH e GGOH}

O protocolo II da reação enzimática foi utilizado com substratos não-radioativos (IPP e DMAPPP) na presença da rPfFFPS. Os produtos formados apartir desta reação foram analisados por ESI-MS/MS (Electrospray Ionization Mass Spectrometry), utilizando um espectometro de massa modelo LCQTM Duo Duo (Thermo Scientific, EUA), acoplado a um sistema nano-HPLC (Ultimate, Dionex, EUA). Depois da reação os produtos foram extraídos com hexano, as amostras foram secas por centrifigação a vácuo e ressuspensos em 40 ul de 
$50 \%$ de ácido fórmico acetronitrila/ $0,2 \%$. A amostra foi injetada $(10 \mu \mathrm{l})$ na sonda nano do espectrometro por uma amostrador automático (Ultimate, Dionex, EUA) a um fluxo de 2 $\mu 1 /$ min e analisada no modo positivo, usando os seguintes parâmetros: pulverização de tensão $1,8 \mathrm{kV}, 38 \mathrm{~V}$ de tensão capilar, temperatura $180^{\circ} \mathrm{C}$. Para ESI-MS/MS, a energia de colisão relativa de $30 \%(1,5 \mathrm{eV})$ foi aplicada.

\subsection{Purificação parcial da PfFPPS nativa}

A purificação parcial da PfFPPS nativa foi realizada apenas com parasitas no estágio de esquizonte, obtidos após purificação com a coluna CS, como descrito anteriormente. A purificação parcial da proteína foi realizada de acordo com Tonhosolo et al. (2009). Extratos de parasitas foram resuspensos em $2 \mathrm{ml}$ de Tampão A (Tris- HCL $50 \mathrm{mM} \mathrm{pH} \mathrm{7,5,} \mathrm{EDTA}$ $1 \mathrm{mM}$; PMSF 0,2 mM; leupeptina 0,1 $\mathrm{mM}$ ) e submetidos a lise mecânica em sonicador (quatro pulsos de $15 \mathrm{~s}$ em $40 \mathrm{~W}$, com intervalo de $30 \mathrm{~s}$, a $4{ }^{\circ} \mathrm{C}$ ). Posteriormente, realizou-se uma ultra centrifugação a $100000 \times \mathrm{g}$ por uma hora a $4{ }^{\circ} \mathrm{C}$. O sobrenadante (s-100) foi submetido à precipitação 0-50\% com sulfato de amônia. O precipitado foi ressuspenso em $3 \mathrm{ml}$ de tampão B (Tris- $\mathrm{HCl} 50$ mM, pH 7,5; DTT $1 \mathrm{mM}, \mathrm{ZnCl}_{2} 20 \mu \mathrm{M}$ e $\mathrm{NaCl} 20 \mathrm{mM}$ ) e dialisado por 20 horas a $4{ }^{\circ} \mathrm{C}$, no tampão da reação enzimática (protocolo II), o qual foi utilizado para verificar a atividade enzimática dessa proteína. Os produtos difosfatos foram analisados por HPLC como descrito acima.

\subsection{Determinação dos parâmetros cinéticos da enzima recombinante}

O protocolo I foi utilizado para estudos cinéticos da rPfFPPS. As concentrações de DMAPP, GPP e FPP ou $\left[1-{ }^{14} \mathrm{C}\right] \mathrm{IPP}$ foram variadas, enquanto a concentração do outro substrato foi mantida na concentração de saturação. Após a reação os produtos da reação foram extraídos com hexano e por contagem com líquido de saturação. Os valores de $K_{m}$ e $V_{\max }$ foram determinados pelo método mínimo quadrado utilizando o software EnzFitter ${ }^{\circledR}$.

\subsection{Inibição da atividade da rPfFPPS}

A atividade de rPfFPPS foi ensaiada pelo protocolo I na presença de diferentes concentrações de risedronato $(1 \mathrm{nM}-1 \mathrm{mM})$. Risedronato foi incubado na mistura contendo Hepes 10mM, pH 7,4, $\mathrm{MgCl}_{2} 2 \mathrm{mM}$, ditiotreitol $2 \mathrm{mM},\left[4-{ }^{14} \mathrm{C}\right] \mathrm{IPP} 30 \mu \mathrm{M}, 30 \mu \mathrm{M}$ dos 
substratos alílicos (DMAPP ou GPP ou FPP), e 500 ng de proteína, num volume final de 100 $\mu \mathrm{L}$. Reagentes foram incubados durante $30 \mathrm{~min}$ a $37{ }^{\circ} \mathrm{C}$, e os produtos extraídos e quantificados por contagem em líquido de cintilação. Os valores de $\mathrm{IC}_{50}$ e $K_{i}$ foram calculados de acordo com a equação abaixo (Sanders et al., 2003).

$$
K_{i}=\frac{I C_{50}}{1+\frac{[S]}{K_{M}}}
$$

\subsection{Imunizações em camundongos com a provável FPPS recombinante}

A proteína de fusão purificada com GST, o antígeno controle-GST e a proteína fusionada com his tag foram utilizados em imunização de camundongos de linhagem Balb/C (disponíveis no Biotério do Departamento de Parasitologia ICB-USP) para a obtenção de anticorpos policlonais monoespecíficos contra a FPPS. Foram imunizados três camundongos com proteína recombinante fusionada com GST, assim como o antígeno GST, mais três camundongos com proteína recombinante fusionada com his-tag. Tais camundongos foram submetidos a três imunizações, com intervalos de 21 dias cada, sendo imunizados com 60 $\mu \mathrm{g} / \mathrm{ml}$ de proteína de fusão injetada por via cutânea. A primeira dose foi administrada com adjuvante completo de Freud (Sigma, St. Louis, MO); as duas imunizações posteriores foram administradas com adjuvante incompleto de Freund (Sigma, St. Louis, MO). Após sete dias da última imunização, o soro dos camundongos assim obtidos foi coletado por punção da veia retro-ocular. Os anti-soros de camundongos assim obtidos foram inicialmente utilizados para verificar se a imunização com a proteína recombinante induziria a produção de anticorpos que reconhecem a versão nativa nos três diferentes extratos proteícos dos estágios intraeritrocitários de $P$. falciparum.

\subsection{Análise dos anticorpos por Western blotting}

Parasitas (anel, trofozoítas e esquizontes) separados pelo gradiente de Percoll ${ }^{\circledR}$ foram ressuspendidos em um tampão Ten-Triton (Kessler, 1975). Os extratos resultantes foram submetidos a eletroforese em gel de gradiente de poliacrilamida de 5-20\% em condições desnaturantes. A seguir, as proteínas foram transferidas por eletroforese para membranas de 
nitrocelulose (Hybond-C, Amersham), as quais foram bloqueadas com albumina bovina a 2\% $(\mathrm{p} / \mathrm{v})$. Utilizamos os anticorpos anti-recombinate GST, anti-GST e anti-recombinate his-tag. 


\subsection{Atividade de risedronato sobre a biossíntese de isoprenóides lineares e isoprenilação de proteínas}

No presente estudo, examinamos a atividade do BP-N risedronato in vitro, e avaliamos o possível mecanismo de ação dessa droga sobre a biossíntese dos intermediários lineares (FPP e GGPP) e isoprenilação de proteínas. Os resultados obtidos encontram-se descritos no artigo já publicado (ver APÊNDICE A).

Dentro os diversos BPs-N em uso clínico, optamos pelo risedronato, pois dentre os BPs-N testados em culturas de $P$. falciparum, ele apresentou-se um dos mais potentes $\left(\mathrm{IC}_{50}\right.$ de $120 \mu \mathrm{M})$ (Ghosh et al., 2004; Martin et al., 2001). Apesar desse composto já ser utilizado em cultivo de Plasmódio, testamos novamente em nossas condições de cultivo, e o valor de $\mathrm{IC}_{50}$ encontrado foi de 20,3 $\mu \mathrm{M}$, o valor obtido está dentro do intervalo de valores obtidos com o mesmo isolado (3D7) em estudos anteriores (Martin et al., 2001; Singh et al., 2010). Nesse caso, fomos avaliar se a inibição induzida pelo risedronato em cultura de $P$. falciparum poderia ser revertida após a incubação com esses compostos. Como resultado, obtivemos que o efeito inibitório do risedronato foi revertido pela adição simultânea de $1 \mu \mathrm{M}$ de FPP ou GGPP durante $48 \mathrm{hrs}$ de tratamento $(88.3 \% \pm 9.1 \%$ e $83.5 \% \pm 9.8 \%$ de crescimento, respectivamente). Em contraste, quando IPP, um precursor anterior ao intermediário FPP, foi incubado nas mesmas condições experimentais, o efeito inibitório do risedronato não foi revertido, validando a hipótese que FPPS é um potencial alvo do risedronato. E que o efeito ocasionado pela presença de GGPP, também nos sugeriu que risedronato poderia também estar inibindo a GGPPS. O mesmo efeito de recuperação foi observado depois da coincubação de macrófagos J774 com alendronato e FPP ou GGPP, observando uma prevenção parcial nos eventos apoptóticos (Luckman et al., 1998). Ensaios de recuperação utilizando FOH e GGOH sobre FPPS e GGPPS foram utilizados em T. brucei, P. vivax e células tumorais humanas para identificar o possível alvo dos bisfofonatos (Artz et al., 2011; Martin et al., 2002; Zhang et al., 2009).

Por inibir a FPPS, BPs-N evita a síntese de FPP e metabólitos posteriores como GGPP. Estes isoprenóides são esqueletos estruturais para uma variedade de metabólitos, como o dolicol, ubiquinona e modificação pós-traducional de proteínas. Para determinar o efeito inibitório do risedronato na biossíntese dos intermediários lineares FPP e GGPP da via de isoprenóides, parasitas foram tratados por 36 horas com $15 \mu \mathrm{M}$ de risedronato e marcados 
nas ultimas 16 horas com $\left[1-{ }^{14} \mathrm{C}\right]$ IPP. Após a purificação dos parasitas no estágio de esquizonte, os isoprenoídes foram extraídos e analisados por HP-TLC. Devido ao baixo sinal de marcação, apenas parasitas no estágio de esquizonte foram analisados. Como resultado, observamos que a incorporação do $\left[1-{ }^{14} \mathrm{C}\right] \mathrm{IPP}$ foi inibida em parasitas tratados com risedronato, quando comparado com parasitas não tratados, assim a intensidade das bandas com valores de $R_{f}$ correspondentes aos padrões de farnesol (FOH) e geranilgeraniol (GGOH) apresentaram-se diminuídas. A intensidade das bandas, com $R_{f}$ equivalente a prenol de 8 e 9 unidades isoprênicas, também foi reduzida. Esses dados nos indicam que risedronato diminui a síntese dos produtos FPP e/ ou GGPP, provavelmente por conseqüência da inibição da enzima FPPS.

Grupos isoprênicos como FPP e GGPP gerados pela FPPS e GGPPS podem ser transferidos para resíduos de cisteína no motivo carboxil em várias classes de proteínas, incluindo a família de proteínas de ligação a GTP Ras, Rho, Rac e Rab (McTaggart, 2006). O proceso de farnesilação e geranilgeranilação de proteínas foi demonstrado anteriormente em P. falciparum (Moura et al., 2001). Assim com a inibição da síntese de FPP e GGPP, possivelmente pela inibição da FPPS por risedronato, fomos investigar o que estaria ocorrendo com a isoprenilação das proteínas no parasita. Para isso, parasitas foram tratadas por 36 horas com $15 \mu \mathrm{M}$ de risedronato, seguido de marcação metabólica com $\left[1-{ }^{3} \mathrm{H}\right] \mathrm{FPP}$ ou $\left[1-{ }^{3} \mathrm{H}\right]$ GGPP. Os parasitas foram separados por gradiente de Percoll e as proteínas extraídas e analisadas por gel de poliacrilamida para se verificar a incorporação dos precursores nas proteínas isopreniladas. Anteriormente demonstrou-se que ácido zolendrônico inibe a incorporação de $\left[{ }^{14} \mathrm{C}\right]$ mevalonato em pequenas proteínas GTPase preniladas purificadas de osteoclasto in vitro (Luckman et al., 1998). Em macrófagos J774, BPs-N inibe a prenilação de proteínas, incluindo a prenilação de proteínas Ras.Uma vez mostrado que risedronato inibe a biossíntese de FPP e GGPP, esperava-se que, marcações metabólicas com [1- $\left.{ }^{3} \mathrm{H}\right] \mathrm{FPP}$ e [1${ }^{3} \mathrm{H}$ ]GGPP, haveria um aumento na intensidade nas bandas correspondentes às proteínas isopreniladas. No entanto, nas auto-radiografias de géis marcados com $\left[1-{ }^{3} \mathrm{H}\right] \mathrm{FPP}$, observamos uma diminuição das proteínas farnesiladas, podendo especular que a transferência do $\left[1-{ }^{3} \mathrm{H}\right] \mathrm{FPP}$ exógeno está inibida. Estes resultados são suportados por dados de literatura que mostra vários bisfosfonatos análogos de FPP inibindo a farnesiltransferase (Holstein et al., 1998). Por outro lado, o perfil de intensidade das bandas correspondentes as proteínas geranilgeraniladas estava aumentado, provavelmente porque a transferência de GGPP à proteínas não foi alterada pela risedronato. 
Para caracterizar se risedronato inibe especificamente as proteínas $\mathrm{p} 21^{\text {ras }}$ e p $21^{\text {rap }}$ de $P$. falciparum, lisados de parasitas no estágio esquizonte tratados e não tratados, marcados metabolicamente com $\left[1-{ }^{3} \mathrm{H}\right] \mathrm{FPP}$ ou $\left[1-{ }^{3} \mathrm{H}\right] \mathrm{GGPP}$ foram imunoprecipitados com anticorpos anti-p2 $1^{\text {ras }}$ ou anti-p2 $1^{\text {rap }}$ respectivamente e analisados por SDS-PAGE. Quando observamos imunoprecipitados tratados e não tratados e marcados com os diferentes precursores [1$\left.{ }^{3} \mathrm{H}\right]$ FPP e $\left[1-{ }^{3} \mathrm{H}\right]$ GGPP obtivemos o mesmo perfil descrito acima, de uma possível inibição da transferência do grupo FPP para proteínas e ausência de inibição da transferência do GGPP paras a proteínas. Considerando que as proteínas Ras e Rab são farnesiladas e geranilgeraniladas respectivamente, a inibição de Ras e aumento de proteínas Rab após incubação risedronato confirma a nossa hipótese de que, em $P$. falciparum risedronato inibe FPPS e consequentemente bloqueia o processo de farnesilação e geranilgeranilação das proteínas, por uma possível inibição da FPP de $P$. falciparum.

Estes resultados mostram que risedronato também pode inibir a GGPPS de $P$. falciparum ou que a síntese de GGPP está inibida, como consequência da inibição de FPP. Singh et al. (2010) mostraram recentemente que os bisfosfonatos lipofílicos têm atividade contra uma GGPPS recombinante de P. vivax (Singh et al., 2010) e recentemente mostrou-se que o risedronato inibe GGPPS recombinante de $P$. vivax, utilizando ensaios de atividade enzimática e abordagens de cristalografia (Artz et al., 2011) e em T. gondii, BPs- N inibe a enzima bifuncional FPPS/GGPPS (Ling et al., 2007).

Em conclusão, nossos resultados mostraram que risedronato interfere com as proteínas farnesiladas e geranilgeraniladas de $P$. falciparum por consenquência da inibição da biossíntese de FPP e GGPP, possivelmente pela inibição da enzima FPPS. Nós também mostramos que risedronato inibe a tranferência do FPP para as proteínas farnesiladas do parasita. No entanto, experimentos adicionais são necessários para avaliar a especificidade do risedronato na inibição da proteína farnesiltransferase em $P$. falciparum. E atividade plasmodial dos BPs-N pode ser explorada como potenciais candidatos antimaláricos.

\section{- "In vitro and in vivo antiplasmodial activies of risedronate and its interference with protein prenylation in Plasmodium falciparum” (APÊNDICE A)}




\subsection{Caracterização da enzima recombinante farnesil difosfato sintase de $P$. falciparum (rPfFPPS)}

No presente estudo, nos clonamos, expressamos e caracterizamos a enzima FPPS de $P$. falciparum e examinamos a atividade do $\mathrm{BP}-\mathrm{N}$ risedronato sobre a versão recombinate da proteína (ver APÊNDICE B).

Para a caracterização da enzima FPPS de P. falciparum identificamos no banco de dados do Plasmo DB o gene Pf11_0295 como possível candidato. Quando iniciamos nosso trabalho, o gene Pf11_0295 de P. falciparum estava anotado como FPPS, atualmente ele é anotado como uma GGPPS. O alinhamento das seqüências de nucleotídeos foi realizado utilizando o software Clustal W, e a comparação das seqüências de nucleotídeos de FPPS de P. falciparum com outras FPPS já caracterizadas, demonstraram a presença de dois domínios ricos em aspartato altamente conversados, que têm um motivo $\mathrm{DDXX}(\mathrm{XX}) \mathrm{D}$ (onde $\mathrm{X}$ pode ser qualquer aminoácido) que são os domínios FARM (Primeiro domínio rico em aspartato) e SARM (Segundo domínio rico em aspartato). Estes domínios estão localizados nas regiões II e VI respectivamente, dos 7 motivos de aminoácidos conservados. Vários experimentos de mutação sítio-direcionada têm mostrado que o aminoácido conservado Asp presente nessas regiões são cruciais para a função catalítica da enzima (Wang, Ohnuma, 2000). 
Figura 6- Alinhamento de sequência da FPPS de P. falciparum.

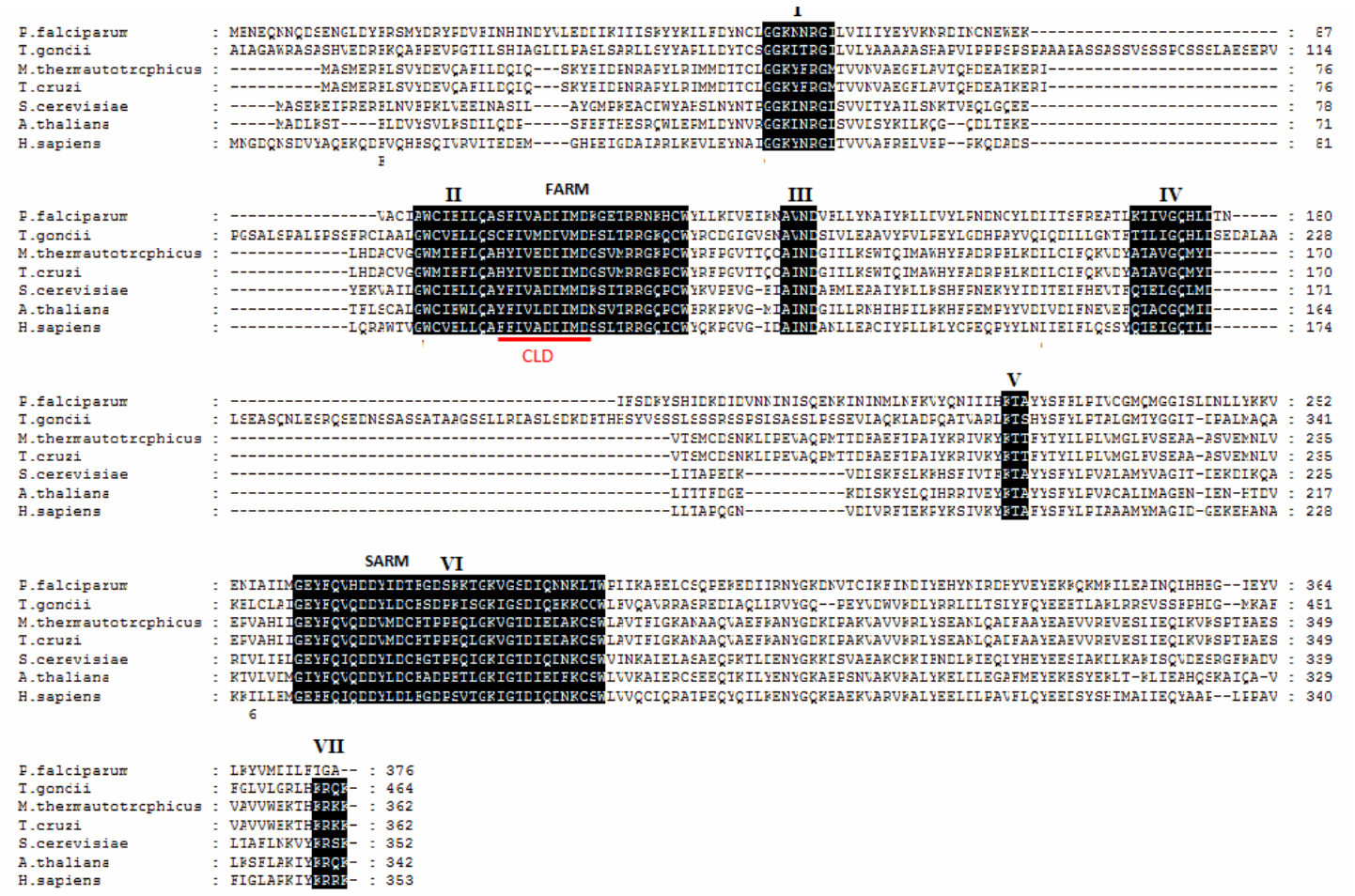

Os sete motivos conservados de aminoácidos estão destacados em preto, o CLD está em vermelho, junto com o domínio FARM e posteriomente se encontra o domiínio SARM.

Oligonucleotídeos específicos para o gene que codifica a FPPS de P. falciparum foram desenhados e usados para amplificação por PCR. Um produto de $1131 \mathrm{pb}$ foi obtido, posteriormente o fragmento foi purificado e clonado no vetor pTZ, utilizando a bactéria Escherichia coli cepa DH-10B.

Figura 7- Amplificação por PCR do gDNA do gene Pf11-0295 de P. falciparum.

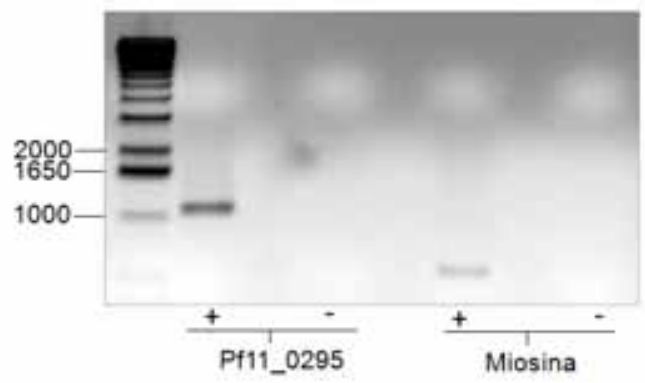

O produto do PCR $\sim 1131$ pb.na coluna + com gDNA, - sem gDNA. O produto amplificado foi clonado e sequênciado para confirmar a sequência do gene.

Os clones obtidos foram sequenciados e clones com a sequência correta foram subclonados nos vetores de expressão. Inicialmente o gene PfFFPPS foi inserido no plasmídio 
de expressão pRESTa, que expressa uma proteína recombinante fusionada a tag de histidina. A purificação da proteína, mostrou uma banda de aproximadamente $44 \mathrm{kDa}$, correspondente a proteína expressa no parasita. No entanto, quando realizamos os experimentos de atividade enzimática, a proteína não apresentou atividade. A expressão de uma proteína recombinate fusionada a tag de histidina ativa foi utilizada anteriormente para a caracterização da FPPS de T.cruzi (Montalvetti et al., 2001), e a caraterização da atividade OPPS/Fitoeno da proteína recombinante de $P$. falciparum, também estava fusionada com a cauda de histidina, demostrando que é possível esse tipo de sistema de expressão no parasita (Tonhosolo et al., 2009; Tonhosolo et al., 2005).

Figura 8- Expressão da versão recombinante da FPPS fusionada a his-tag.

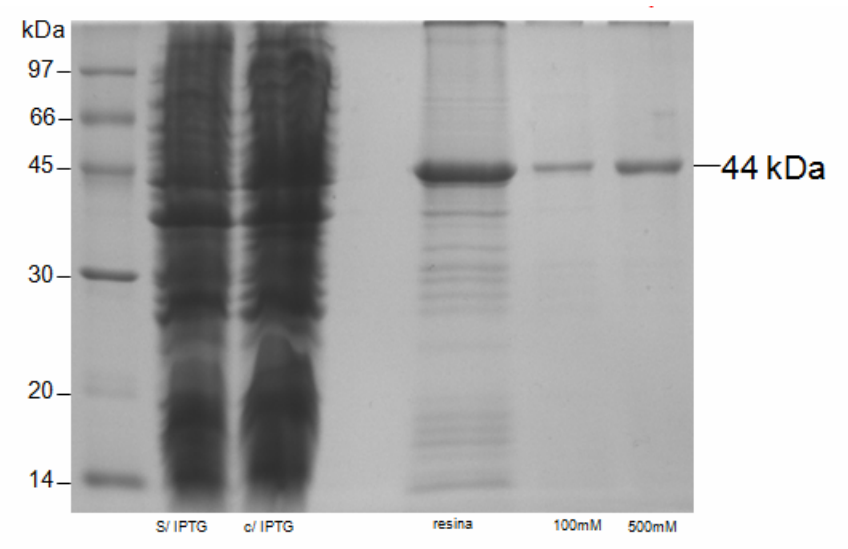

Proteína purificada de $44 \mathrm{kDa}$. Colunas contém: sobrenante induzido ou não com IPTG, resina e 100mM ou 500 mM imidazol.

Posteriormente o gene da FPPS foi inserido no plasmídeo de expressão pGEX-2T, que expressa a proteína recombinante em fusão com a GST (glutationa S-Transferase) de 26 $\mathrm{kDa}$. A purificação da proteína expressa no vetor pGEX-2T mostrou apenas algumas bandas contaminantes e uma banda majoritária de massa molecular de $70 \mathrm{kDa}$ foi observada, correspondente a $44 \mathrm{kDa}$ da FPPS $+26 \mathrm{kDa}$ da GST, denominada agora de rPfFPPS. Essa proteína posteriormente foi utilizada para caracterização da atividade funcional e determinação dos parâmetros cinéticos da rPfFPPS. A remoção da GST de rPfFPPS resultou na perda quase completa da atividade. Uma forma ativa da GGPPS de Thermus thermophilus e Acidocaldarius sulfolobus também foi superexpressa fusionada a GST (Ohto et al., 1998).

Diversos trabalhos anteriores mostraram que a enzima FPPS de diversos organismos, aceitam DMAPP e GPP como substratos alílicos (Reed, Rilling, 1975, 1976). Quando a enzima sintetiza FPP apartir de DMAPP, a enzima completa duas reações de condensaçao 
com IPP, formando o GPP que é um produto intermediário e, quando utiliza o GPP como substrato apenas o FPP é observado. A FPPS, com atividade bifuncional, como no caso da enzima de T. gondii, que sintetiza tambem GGPP, pode aceitar DMAPP, GPP and FPP como substratos (Ling et al., 2007).

A atividade da rPfFPPs foi avaliada utilizando dois diferentes protolocos, como descrito nos materiais e métodos. Para a realização dos dois protocolos de reação utilizou-se como substrato $\left[{ }^{14} \mathrm{C}\right]$ IPP e os subtratos alílicos, DMAPP ou GPP ou FPP. Produtos formados apartir do protocolo I, foram analisados por HPLC, para observação dos produtos na forma difosfato. Na reação catalisada por rPfFPPs utilizando $\left[{ }^{14} \mathrm{C}\right] \mathrm{IPP}$ e DMAPP, foram sintetizados os produtos GPP, FPP e GGPP, quando $\left[{ }^{14} \mathrm{C}\right]$ IPP e GPP foram os substratos, foram sintetizados os produtos FPP e GGPP. Quando foram utilizados $\left[{ }^{14} \mathrm{C}\right] \mathrm{IPP}$ e FPP como substratos somente o GGPP foi detectado como produto.

Os produtos formados apartir do protocolo II foram extraídos com hexano e analisados por TLC. Quando DMAPP foi utilizado como substrato, observamos que GOH foi detectado, enquando $\mathrm{FOH}$ e GGOH foram os produtos predominantes. Quando a reação foi catalisada com GPP como subtrato alílico, os únicos produtos observados foram $\mathrm{FOH}$ and $\mathrm{GGOH}$. Consequentemente quando FPP foi utilizado como substrato apenas GGOH foi observado. Para confirmar mais uma vez que FPPS poderia mesmo formar o produto GGPP, utilizamos $\left[1-{ }^{3} \mathrm{H}\right] \mathrm{FPP}$ e IPP como substratos e o produto GGPP foi mais uma vez observado por HPLC, confirmando a especificidade da reação. Portanto, demonstrou-se que os mesmos produtos foram observados por duas metodologias diferentes. Confirmando que FPP e GGPP são os produtos predominates da rPfFFPS. Quando $\left[{ }^{14} \mathrm{C}\right] \mathrm{IPP}$ e IPP foram utilizados como substrato, nenhum produto foi biossintetizado. Produtos nao foram formados quando GGPP foi utilizado como substrato. É importante ressaltar que não ocorreu a formação dos produtos sem a adição da proteína recombinante e, o mesmo ocorreu utilizando apenas a GST, confirmando a atividade enzimática da proteína recombinante. A formação dos produtos FPP e GGPP pela enzima rPfFPPS foi confirmada por espectrometria da massas ESI/MS/MS utilizando os substratos DMAPP e IPP não-radioativos utilizando o protocolo I.

Apartir dos resultados obtidos, podemos afirmar que a rPfFPPs de P. falciparum, possui realmente atividade de FPPS e GGPPS. Resultados semelhantes foram encontrados, até o momento, somente em mais dois organismos: T. gondi (Ling et al., 2007) e Metanobacteria termoautotrofica (Chen, Poulter, 1993; Fujiwara et al., 2004). Em contraste, a enzima FPPS recombinante de T. brucei sintetiza somente FPP (Montalvetti et al., 2001) e a GGPPS de P. vivax é capaz de formar apenas o produto GGPP (Artz et al., 2011). 
Com o objetivo de verificar os produtos formados pela enzima nativa do parasita, a determinação da atividade enzimática foi realizada com um extrato de proteínas parcialmente purificado de parasitas no estágio de esquizonte com sulfato de amônia 50\%. A atividade foi testada utilizando o protocolo II e os produtos formados foram analisados pelo protocolo II (HPLC). Quando $\left[{ }^{14} \mathrm{C}\right]$ IPP e DMAPP foram utilizados como substrato, os produtos GPP, FPP e GGPP foram sintetizados, quando $\left[{ }^{14} \mathrm{C}\right] \mathrm{IPP}$ e GPP foram os substratos, os produtos FPP e GGPP foram sintetizados. Quando utilizamos $\left[{ }^{14} \mathrm{C}\right]$ IPP e FPP somente o GGPP foi detectado como produto. Os resultados obtidos confirmam a atividade da proteína nativa de $P$. falciparum com as mesmas características da proteína rPfFPPS. Esse mesmo perfil foi observado com a OPPS nativa de P. falcilparum (Tonhosolo et al., 2005). Os resultados obtidos mais uma vez demostraram a bifuncionalidade da FPPS de P. falciparum, mostrado mais uma vez que os principais produtos formados pela enzima são FPP e GGPP.

Os parâmetros cinéticos rPfFPPS foram determinadas utilizando $\left[1-{ }^{14} \mathrm{C}\right] \mathrm{IPP}$, DMAPP, GPP e FPP como substratos e utilizado o protocolo I, medindo a radioatividade dos produtos formados extraídos com hexano. Os valores de $K_{m}$ e $V_{\max }$ foram obtidos pelo método de regressão não-linear e a equação de Michaelis-Menten (Enziffiter versão 3.06). A quantidade de produto formado por $500 \mathrm{ng}$ da rPfFPPS, foi medida fixando um substrato e variando a concentração do outro. Valores de $K_{m}$ para os substratos IPP e FFP foram observados pela GGPPS de $H$. Sapiens $(3 \pm 0,2 \mu \mathrm{M}$ e 4,2 $\pm 0,3 \mu \mathrm{M})$ e GGPPS de $P$. vivax $(8.4 \pm 1.6 \mu \mathrm{M}$ e 7.3 $\pm 0.7 \mu \mathrm{M}$ ). Os valores dos substratos IPP e FPP de $P$. falciparum foi parecido com valores de $K_{m}$ de, $2.4 \pm 0.3 \mu \mathrm{M}$ e $2.06 \pm 0.4 \mu \mathrm{M}$. Os valores para os substratos IPP e GPP indicam valores semehantes para o IPP $(0.81 \pm 0.1 \mu \mathrm{M})$ e quase dez vezes maiores para o GPP $(7.8 \pm$ $1.3 \mu \mathrm{M})$. Resultados semelhantes foram observados na enzima bifuncional de T. gondi.

Sabe-se que o comprimento da cadeia, de produtos das FPPS e GGPPS, é regulado principalmente pelos resíduos de aminoácidos localizados na $4^{\circ}$ e $5^{\circ}$ posição antes do domínio FARM. Quando comparamos a sequência de aminoácios da FPPS de P. falciparum com o padrão de aminoácios para a classificação das FPPS e GGPPS de acordo com a localização do aminoácido na $4^{\circ}$ e $5^{\circ}$ posição antes do FARM nos deparamos com diferenças semelhantes as observadas anteriomente na FPPS de T. gondii. Quando analisamos o alinhamento das enzimas FPPS bifuncionais de T.gondii e $M$. termoautotrofica com a FPPS de $P$. falciparum também bifuncional e GGPPS de $P$. vivax, observamos que as sequências destas enzimas são parecidas. T. gondi, P. falciparum e P. vivax possuem uma fenilanina na $5^{\circ}$ posição antes do domínio FARM, e na $4^{\circ}$ posição observa-se a presença de aminoácido menores, T. gondi possui uma cisteína presente na $4^{\circ}$ posição, em $P$. falciparum se observa uma uma serina. 
Recentemente demostrou-se que a cisteína de T.gondii é responsável pela sua bifuncionalidade ( $\mathrm{Li}$ et al., 2012), por serina também não ser um aminoácido aromático pode se sugerir que a cisteína também é importante para determinação do tamanho da cadeia em $P$. falciparum e explicar a bifuncionalidade encontrada também em P. falciparum. Como a PvGGPPS produz exclusivamente GGPP ela também poderia ser uma enzima bifuncional, pela análise da sequência (Artz et al., 2011). Por outro lado, outra enzima bifuncional, a de $M$. termoautotrofica contém um fenilalanina na $4^{\circ}$ posição e também produz FPP e GGPP.

Figura 9- Comparação da região CLD e domínio FARM das enzimas FPPS bifuncionais.

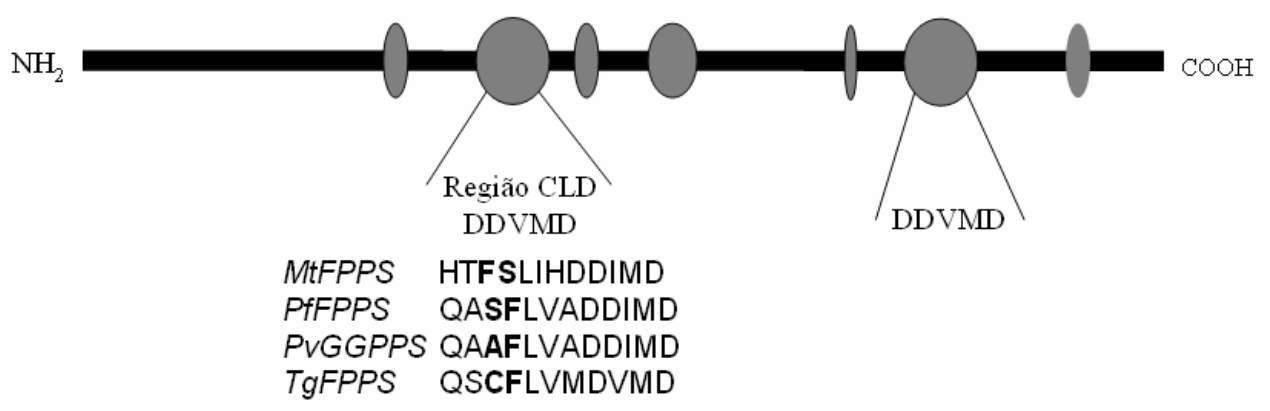

PfFPPS, P. falciparum; TgFPPS, Toxoplasma gondii; PvGGPPS, Plasmodium vivax; MtFPPS, M. termoautotrofica.

Diversos trabalhos demonstraram que BPs-N inibem a enzima FPPS. Recentemente tem se explorado a inibição da PvGGPPS com diversos tipos de bisfosfonatos, incluindo também os lipofilicos. Nossos dados anteriores apontavam que risedronato poderia estar inibindo a FPPS de P. falciparum e para comprovar este dado, fomos investigar o efeito desse composto diretamente sobre a enzima recombinante. Pretendíamos determimar os valores de $K_{i}$ (Constante de inibição) do risedronato, mas devido as dificuldades metodológicas determinamos a $\mathrm{IC}_{50}$, e o $\mathrm{Ki}$ foi determinado a partir desses valores.

Os valores de $\mathrm{IC}_{50}$ do risedronato foram de $1.3 \pm 0.3 \mu \mathrm{M}$ e $10 \pm 1 \mu \mathrm{M} \mu \mathrm{M}$ quando utilizamos FPP e GPP como substratos alílicos. Os nossos valores de $\mathrm{IC}_{50}$ são menores do que o observado em relação a humana, com valor de $\mathrm{IC}_{50}$ de $350 \mu \mathrm{M}$. No entanto, eles são mais elevados do que os encontrados em TgFPPS com $\mathrm{IC}_{50}$ de $0,074 \mu \mathrm{M}$ e PvGGPPS de 0,047 $\mu \mathrm{M}$, mostrando que o risedronato ainda não é o composto mais eficaz para $P$. falciparum. Os análogos lipofílicos desse compostos apresentaram uma forte atividade inibidora contra GGPPS de P. vivax e também exibiu atividade antimalárica, podendo continuar explorando esse alvo.

Soros foram obtidos, por imunização de camundongos com a proteína recombinante PfFPPS, para verificar se a versão nativa da proteína era reconhecida por esses anticorpos. 
Primeiramente realizamos ensaios por western blot para ver se nosso anticorpo é capaz de reconhecer a proteína recombinante FPPS, tanto fusionada com his-tag e GST. Nós obtivemos um anticorpo capaz de reconhecer a proteína FPPS recombinate, tanto fusionada com GST e com his-tag. ,como demonstrado na figura $12 \mathrm{C}$ e D. Com o objetivo de detectar a PfFPPS em extratos proteícos do parasita, western blot foi realizado utilizando o soro das proteínas recombinante fPPS, contudo não foi possível a detecção nós extratos do parasita, provavelmente devido à baixa sensibilidade do método ou ao baixo título do anticorpo obtido. Resultados similares foram encontrados com a FPPS de T. gondi (Ling et al., 2007). Nós pretendíamos também com esse anticorpo realizar experimentos de imunofluorescência e confocal, mas por experiências anteriores percebemos que essa não seria a melhor técnica para identificar a localização da proteína no parasita. 
Figura 10- Ensaios de westem blotting apartir de anti-soro da FPPS.

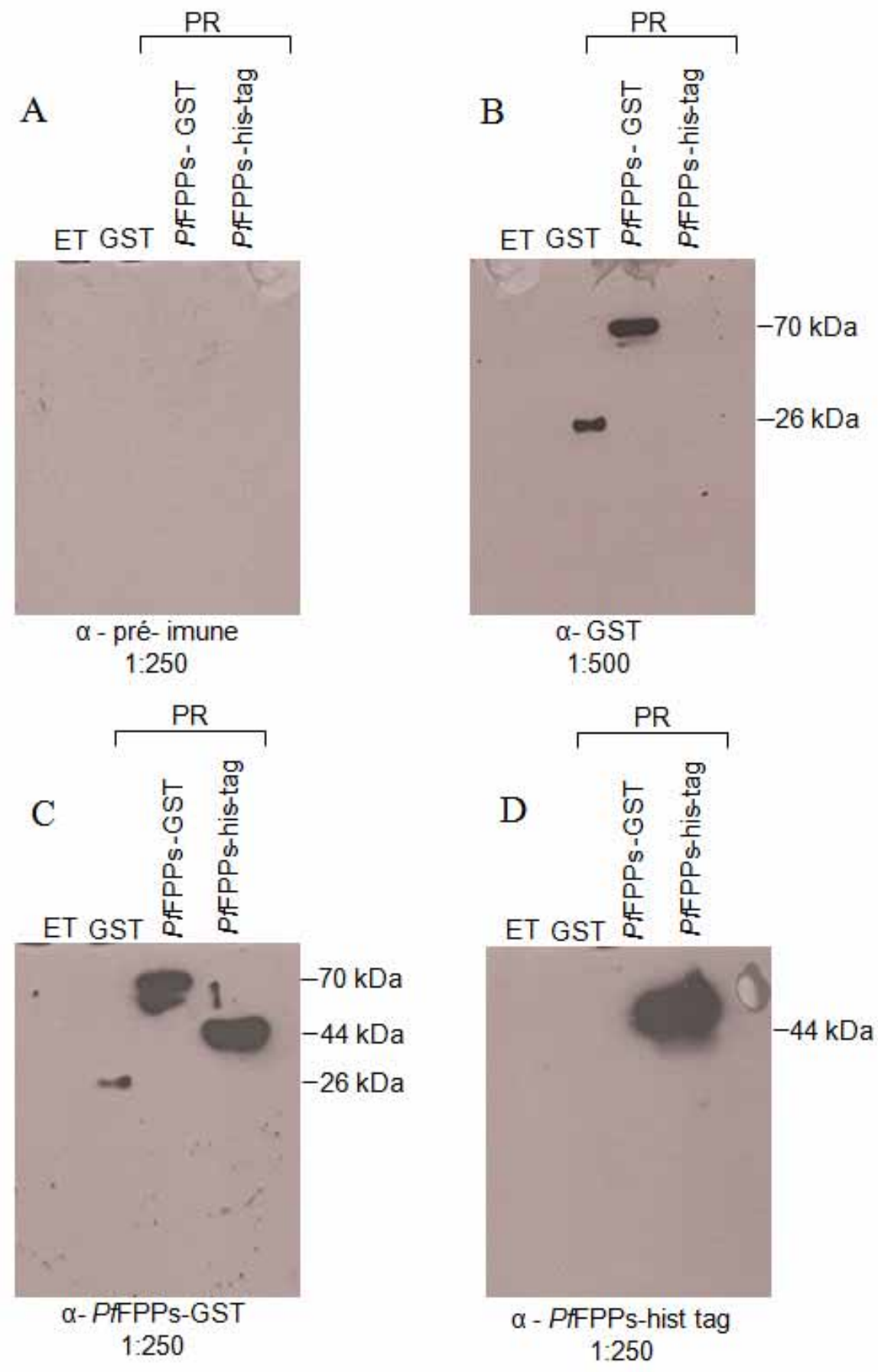

A) soro pré-imune; B) soro anti-GST; C) anti-rPfFPPS; D) anti-PfFPPS-his-tag

Assim nós demonstramos que rPfFPPS é uma enzima bifuncional, capaz de formar FPP e GGPP como produtos, e esses compostos ocupam uma posição central na sintese de isoprenóides e são intermediários para a síntese de diversos compostos isoprênicos já caraterizados no parasita. Além disso, mostramos também que risedronato apresenta atividade 
contra essa enzima. Ensaios de cristalização da rPfFPPS com o inibidor seriam complementares no prosseguimento deste estudo.

-“Cloning and characterization of bifunctional enzyme farnesyl diphosphate synthase/ geranilgeranyl diphosphate synthase of Plasmodium falciparum". (manuscrito submetido) (APÊNDICE B) 
4 CONCLUSÕES 
A partir dos resultados apresentados na presente tese concluímos que risedronato apresenta atividade in vivo na faixa de concentração de micromolar contra as formas intraeritrocitárias de $P$. falciparum. A inibição dos parasitas foi recuperada quando os intermediários FPP e GGPP da via de biossíntese de isoprenóides foram adicionados ao cultivo simultaneamente com a droga, evidenciado assim que a inibição poderia estar envolvida com a via de isoprenoídes.

Estudos com marcação metabólica apontaram que risedronato inibe a biossíntese dos intermediários FPP e GGPP e consequentemente interfere no processo de isoprenilação de proteínas, que ocorre pela presença desses dois compostos. Essa inibição pode ser devido à inibição da enzima FPPS que é conhecida por ser alvo de bisfosfonatos.

A partir da clonagem e expressão obteve-se uma enzima FPP recombinate fusionada a GST (rPfFPPS), que foi utilizada para sua caracterização. A caracterização dessa enzima foi realizada por ensaios enzimáticos utilizando IPP, DMAPP, GPP e FPP como substratos alílicos, demostrando que está é uma enzima bifuncional, com atividade de FPPS e GGPPS, capaz de formar os produtos FPP e GGPP, confirmado pelas metodologias de TLC, HPLC e espectometria de massas. A reção realizada com extratos de protéinas de parasitas nos estágios de esquizonte e analisada por HPLC também observamos a presença de FPP e GGPP como principais produtos.

A investigação de risedronato sobre a rPfFPPS sugere mais uma vez que inibição dos intermediários FPP e GGPP é consequência da inibição da enzima FPPS. Apesar dos análogos dos bifosfonatos conhecidos como bifosfonatos lipofílicos serem mais eficientes contra a GGPPS de $P$. vivax, os resultados obtidos aqui evidenciam que risedronato é capaz de inibir a FPPS e interferir na biossíntese de FPP e GGPP que são compostos chaves da via de biossíntese de isoprenoídes, onde a inibição desses compostos alteraria toda a maquinaria de biossíntese dos compostos isoprênicos. 
REFERÊNCIAS 
Alexandre MA, Ferreira CO, Siqueira AM, et al. Severe Plasmodium vivax malaria, Brazilian Amazon. Emerg Infect Dis. 2010;16(10):1611-4.

Artz JD, Dunford JE, Arrowood MJ, et al. Targeting a uniquely nonspecific prenyl synthase with bisphosphonates to combat cryptosporidiosis. Chem Biol. 2008;15(12):1296-306.

Artz JD, Wernimont AK, Dunford JE, et al. Molecular characterization of a novel geranylgeranyl pyrophosphate synthase from Plasmodium parasites. $\mathrm{J}$ Biol Chem. 2011;286(5):3315-22.

Ashby MN, Edwards PA. Elucidation of the deficiency in two yeast coenzyme Q mutants. Characterization of the structural gene encoding hexaprenyl pyrophosphate synthetase. J Biol Chem. 1990;265(22):13157-64.

Barbosa J. Situação Epidemiólogica da Malária na Amazônas. 2011. Disponivel: from http://portal.saude.gov.br/portalsaude/arquivos/pdf/2011/Set/05/jarbas_malaria_050911.pdf.[2 012].

Biardi L, Krisans SK. Compartmentalization of cholesterol biosynthesis. Conversion of mevalonate to farnesyl diphosphate occurs in the peroxisomes. $\mathrm{J}$ Biol Chem. 1996;271(3):1784-8.

Blanchard L and Karst F. Characterization of a lysine-to-glutamic acid mutation in a conservative sequence of farnesyl diphosphate synthase from Saccharomyces cerevisiae. Gene. 1993;125(2):185-9.

Borrmann S, Adegnika AA, Matsiegui PB, et al. Fosmidomycin-clindamycin for Plasmodium falciparum Infections in African children. J Infect Dis. 2004;189(5):901-8.

Borrmann S, Lundgren I, Oyakhirome S, et al. Fosmidomycin plus clindamycin for treatment of pediatric patients aged 1 to 14 years with Plasmodium falciparum malaria. Antimicrob Agents Chemother. 2006;50(8):2713-8.

Boucher Y, Doolittle WF. The role of lateral gene transfer in the evolution of isoprenoid biosynthesis pathways. Mol Microbiol. 2000;37(4):703-16.

Bradford MM. A rapid and sensitive method for the quantitation of microgram quantities of protein utilizing the principle of protein-dye binding. Anal Biochem. 1976;72:248-54.

Braun-Breton $\mathrm{C}$, Jendoubi $\mathrm{M}$, Brunet $\mathrm{E}$, et al. In vivo time course of synthesis and processing of major schizont membrane polypeptides in Plasmodium falciparum. Mol Biochem Parasitol. 1986;20(1):33-43.

Carlton JM, Angiuoli SV, Suh BB, et al. Genome sequence and comparative analysis of the model rodent malaria parasite Plasmodium yoelii yoelii. Nature. 2002;419(6906):512-9.

*De acordo com:

ASSOCIACAO BRASILEIRA DE NORMAS TECNICAS. NBR 6023:

Informacao e documentação: referencias: elaboração. Rio de Janeiro. 2002. 
Cassera MB, Gozzo FC, D'Alexandri FL, et al. The methylerythritol phosphate pathway is functionally active in all intraerythrocytic stages of Plasmodium falciparum. J Biol Chem. 2004;279(50):51749-59.

CDC. Centers for Disease Control and Prevention. 2012. Disponivel: from http://www.cdc.gov/malaria/about/biology/.[15 ago 2012].

Chakrabarti D, Azam T, DelVecchio C, et al. Protein prenyl transferase activities of Plasmodium falciparum. Mol Biochem Parasitol. 1998;94(2):175-84.

Chakrabarti D, Da Silva T, Barger J, et al. Protein farnesyltransferase and protein prenylation in Plasmodium falciparum. J Biol Chem. 2002;277(44):42066-73.

Chang TH, Guo RT, Ko TP, et al. Crystal structure of type-III geranylgeranyl pyrophosphate synthase from Saccharomyces cerevisiae and the mechanism of product chain length determination. J Biol Chem. 2006;281(21):14991-5000.

Chen A, Poulter CD. Purification and characterization of farnesyl diphosphate/geranylgeranyl diphosphate synthase. A thermostable bifunctional enzyme from Methanobacterium thermoautotrophicum. J Biol Chem. 1993;268(15):11002-7.

Clarke S. Protein isoprenylation and methylation at carboxyl-terminal cysteine residues. Annu Rev Biochem. 1992;61:355-86.

Couto AS, Kimura EA, Peres VJ, et al. Active isoprenoid pathway in the intra-erythrocytic stages of Plasmodium falciparum: presence of dolichols of 11 and 12 isoprene units. Biochem J. 1999;341 ( Pt 3):629-37.

Cox-Singh J, Singh B. Knowlesi malaria: newly emergent and of public health importance? Trends Parasitol. 2008;24(9):406-10.

Coxon FP, Helfrich MH, Van't Hof R, et al. Protein geranylgeranylation is required for osteoclast formation, function, and survival: inhibition by bisphosphonates and GGTI-298. J Bone Miner Res. 2000;15(8):1467-76.

Cunillera N, Boronat A, Ferrer A. The Arabidopsis thaliana FPS1 gene generates a novel mRNA that encodes a mitochondrial farnesyl-diphosphate synthase isoform. J Biol Chem. 1997;272(24):15381-8.

D'Alexandri FL, Kimura EA, Peres VJ, et al. Protein dolichylation in Plasmodium falciparum. FEBS Lett. 2006;580(27):6343-8.

de Macedo CS, Uhrig ML, Kimura EA, et al. Characterization of the isoprenoid chain of coenzyme Q in Plasmodium falciparum. FEMS Microbiol Lett. 2002;207(1):13-20.

Desjardins RE, Canfield CJ, Haynes JD, et al. Quantitative assessment of antimalarial activity in vitro by a semiautomated microdilution technique. Antimicrob Agents Chemother. 1979;16(6):710-8.

Development UDf I. Malaria: Burden and Interventios: Evidence Overview. 2010. 
Docampo R, Moreno SN. Bisphosphonates as chemotherapeutic agents against trypanosomatid and apicomplexan parasites. Curr Drug Targets Infect Disord. 2001;1(1):5161.

Ekland EH, Fidock DA. In vitro evaluations of antimalarial drugs and their relevance to clinical outcomes. Int J Parasitol. 2008;38(7):743-7.

Ferella M, Li ZH, Andersson B, et al. Farnesyl diphosphate synthase localizes to the cytoplasm of Trypanosoma cruzi and T. brucei. Exp Parasitol. 2008;119(2):308-12.

Field H, Blench I, Croft S, et al. Protein isoprenylation in Trypanosoma brucei brucei. Biochem Soc Trans. 1996;24(3):433S.

Fujiwara S, Yamanaka A, Hirooka K, et al. Temperature-dependent modulation of farnesyl diphosphate/geranylgeranyl diphosphate synthase from hyperthermophilic archaea. Biochem Biophys Res Commun. 2004;325(3):1066-74.

Funes S, Reyes-Prieto A, Perez-Martinez X, et al. On the evolutionary origins of apicoplasts: revisiting the rhodophyte vs. chlorophyte controversy. Microbes Infect. 2004;6(3):305-11.

Gabelli SB, McLellan JS, Montalvetti A, et al. Structure and mechanism of the farnesyl diphosphate synthase from Trypanosoma cruzi: implications for drug design. Proteins. 2006;62(1):80-8.

Gardner MJ, Hall N, Fung E, et al. Genome sequence of the human malaria parasite Plasmodium falciparum. Nature. 2002;419(6906):498-511.

Ghosh S, Chan JM, Lea CR, et al. Effects of bisphosphonates on the growth of Entamoeba histolytica and Plasmodium species in vitro and in vivo. J Med Chem. 2004;47(1):175-87.

Gleeson MT. The plastid in Apicomplexa: what use is it? Int J Parasitol. 2000;30(10):105370 .

Guiguemde W A, Shelat AA, Bouck D, et al. Chemical genetics of Plasmodium falciparum. Nature. 2010;465(7296):311-5.

Holstein SA, Cermak DM, Wiemer DF, et al. Phosphonate and bisphosphonate analogues of farnesyl pyrophosphate as potential inhibitors of farnesyl protein transferase. Bioorg Med Chem. 1998;6(6):687-94.

Holt RA, Subramanian GM, Halpern A, et al. The genome sequence of the malaria mosquito Anopheles gambiae. Science. 2002;298(5591):129-49.

Hugueney P, Bouvier F, Badillo A, et al. Developmental and stress regulation of gene expression for plastid and cytosolic isoprenoid pathways in pepper fruits. Plant Physiol. 1996;111(2):619-26.

Ibrahim M, Azzouz N, Gerold P, et al. Identification and characterisation of Toxoplasma gondii protein farnesyltransferase. Int J Parasitol. 2001;31(13):1489-97. 
Jambou R, Zahraoui A, Olofsson B, et al. Small GTP-binding proteins in Plasmodium falciparum. Biol Cell. 1996;88(3):113-21.

Jomaa H, Wiesner J, Sanderbrand S, et al. Inhibitors of the nonmevalonate pathway of isoprenoid biosynthesis as antimalarial drugs. Science. 1999;285(5433):1573-6.

Jordao FM, Kimura EA, Katzin AM. Isoprenoid biosynthesis in the erythrocytic stages of Plasmodium falciparum. Mem Inst Oswaldo Cruz. 2011;106 Suppl 1:134-41.

Kavanagh KL, Guo K, Dunford JE, et al. The molecular mechanism of nitrogen-containing bisphosphonates as antiosteoporosis drugs. Proc Natl Acad Sci U S A. 2006;103(20):7829-34.

Kessler SW. Rapid isolation of antigens from cells with a staphylococcal protein A-antibody adsorbent: parameters of the interaction of antibody-antigen complexes with protein A. J Immunol. 1975;115(6):1617-24.

Kimura EA, Couto AS, Peres VJ, et al. N-linked glycoproteins are related to schizogony of the intraerythrocytic stage in Plasmodium falciparum. J Biol Chem. 1996;271(24):14452-61.

Kohler S, Delwiche CF, Denny PW, et al. A plastid of probable green algal origin in Apicomplexan parasites. Science. 1997;275(5305):1485-9.

Kuzuyama T, Shimizu T, Takahashi S, et al. Fosmidomycin, a specific inhibitor of 1-deoxy-dxylulose 5-phosphate reductoisomerase in the nonmevalonate pathway for terpenoid biosynthesis. Tetrahedron Letters. 1998;22 7913-6.

Laemmli UK. Cleavage of structural proteins during the assembly of the head of bacteriophage T4. Nature. 1970;227(5259):680-5.

Li ZH, Cintron R, Koon NA, et al. The N-Terminus and the Chain-Length Determination Domain Play a Role in the Length of the Isoprenoid Product of the Bifunctional Toxoplasma gondii Farnesyl Diphosphate Synthase. Biochemistry. 2012.

Ling Y, Li ZH, Miranda K, et al. The farnesyl-diphosphate/geranylgeranyl-diphosphate synthase of Toxoplasma gondii is a bifunctional enzyme and a molecular target of bisphosphonates. J Biol Chem. 2007;282(42):30804-16.

Luckman SP, Hughes DE, Coxon FP, et al. Nitrogen-containing bisphosphonates inhibit the mevalonate pathway and prevent post-translational prenylation of GTP-binding proteins, including Ras. J Bone Miner Res. 1998;13(4):581-9.

Lujan HD, Mowatt MR, Conrad JT, et al. Identification of a novel Giardia lamblia cyst wall protein with leucine-rich repeats. Implications for secretory granule formation and protein assembly into the cyst wall. J Biol Chem. 1995;270(49):29307-13.

Maltese WA. Posttranslational modification of proteins by isoprenoids in mammalian cells. FASEB J. 1990;4(15):3319-28. 
Marechal E, Cesbron-Delauw MF. The apicoplast: a new member of the plastid family. Trends Plant Sci. 2001;6(5):200-5.

Martin MB, Grimley JS, Lewis JC, et al. Bisphosphonates inhibit the growth of Trypanosoma brucei, Trypanosoma cruzi, Leishmania donovani, Toxoplasma gondii, and Plasmodium falciparum: a potential route to chemotherapy. J Med Chem. 2001;44(6):909-16.

Martin MB, Sanders JM, Kendrick H, et al. Activity of bisphosphonates against Trypanosoma brucei rhodesiense. J Med Chem. 2002;45(14):2904-14.

McFadden GI, Waller RF. Plastids in parasites of humans. Bioessays. 1997;19(11):1033-40.

McTaggart SJ. Isoprenylated proteins. Cell Mol Life Sci. 2006;63(3):255-67.

Montalvetti A, Bailey BN, Martin MB, et al. Bisphosphonates are potent inhibitors of Trypanosoma cruzi farnesyl pyrophosphate synthase. J Biol Chem. 2001;276(36):33930-7.

Montalvetti A, Fernandez A, Sanders JM, et al. Farnesyl pyrophosphate synthase is an essential enzyme in Trypanosoma brucei. In vitro RNA interference and in vivo inhibition studies. J Biol Chem. 2003;278(19):17075-83.

Moura IC, Wunderlich G, Uhrig ML, et al. Limonene arrests parasite development and inhibits isoprenylation of proteins in Plasmodium falciparum. Antimicrob Agents Chemother. 2001;45(9):2553-8.

Mukkamala D, No JH, Cass LM, et al. Bisphosphonate inhibition of a Plasmodium farnesyl diphosphate synthase and a general method for predicting cell-based activity from enzyme data. J Med Chem. 2008;51(24):7827-33.

Nagamune K, Hicks LM, Fux B, et al. Abscisic acid controls calcium-dependent egress and development in Toxoplasma gondii. Nature. 2008;451(7175):207-10.

No JH, de Macedo Dossin F, Zhang Y, et al. Lipophilic analogs of zoledronate and risedronate inhibit Plasmodium geranylgeranyl diphosphate synthase (GGPPS) and exhibit potent antimalarial activity. Proc Natl Acad Sci U S A. 2012;109(11):4058-63.

Ohnuma S, Nakazawa T, Hemmi H, et al. Conversion from farnesyl diphosphate synthase to geranylgeranyl diphosphate synthase by random chemical mutagenesis. J Biol Chem. 1996a;271(17):10087-95.

Ohnuma S, Narita K, Nakazawa T, et al. A role of the amino acid residue located on the fifth position before the first aspartate-rich motif of farnesyl diphosphate synthase on determination of the final product. J Biol Chem. 1996b;271(48):30748-54.

Ohto $\mathrm{C}$, Nakane $\mathrm{H}$, Hemmi $\mathrm{H}$, et al. Overexpression of an archaeal geranylgeranyl diphosphate synthase in Escherichia coli cells. Biosci Biotechnol Biochem. 1998;62(6):12436. 
Ortiz-Gomez A, Jimenez C, Estevez AM, et al. Farnesyl diphosphate synthase is a cytosolic enzyme in Leishmania major promastigotes and its overexpression confers resistance to risedronate. Eukaryot Cell. 2006;5(7):1057-64.

Oyakhirome $\mathrm{S}$, Issifou $\mathrm{S}$, Pongratz $\mathrm{P}$, et al. Fosmidomycin-Clindamycin versus SulfadoxinePyrimethamine in the Treatment of Plasmodium falciparum Malaria: A Randomized Controlled Trial. Antimicrob Agents Chemother. 2007.

Ralph SA, van Dooren GG, Waller RF, et al. Tropical infectious diseases: metabolic maps and functions of the Plasmodium falciparum apicoplast. Nat Rev Microbiol. 2004;2(3):20316.

Reed BC, Rilling HC. Crystallization and partial characterization of prenyltransferase from avian liver. Biochemistry. 1975;14(1):50-4.

Reed BC, Rilling HC. Substrate Binding of avian liver prenyltransferase. Biochemistry. 1976;15(17):3739-45.

Reichenberg A, Wiesner J, Weidemeyer C, et al. Diaryl ester prodrugs of FR900098 with improved in vivo antimalarial activity. Bioorg Med Chem Lett. 2001;11(6):833-5.

Reszka AA, Halasy-Nagy J, Rodan GA. Nitrogen-bisphosphonates block retinoblastoma phosphorylation and cell growth by inhibiting the cholesterol biosynthetic pathway in a keratinocyte model for esophageal irritation. Mol Pharmacol. 2001;59(2):193-202.

Ridley RG. Introduction. Antimalarial drug resistance: ramifications, explanations and challenges. Microbes Infect. 2002;4(2):155-6.

Rodan GA. Mechanisms of action of bisphosphonates. Annu Rev Pharmacol Toxicol. 1998;38:375-88.

Rodrigues Goulart H, Kimura EA, Peres VJ, et al. Terpenes arrest parasite development and inhibit biosynthesis of isoprenoids in Plasmodium falciparum. Antimicrob Agents Chemother. 2004;48(7):2502-9.

Roelofs AJ, Thompson K, Gordon S, et al. Molecular mechanisms of action of bisphosphonates: current status. Clin Cancer Res. 2006;12(20 Pt 2):6222s-30s.

Rogers MJ, Frith JC, Luckman SP, et al. Molecular mechanisms of action of bisphosphonates. Bone. 1999;24(5 Suppl):73S-9S.

Rohmer M, Grosdemange-Billiard C, Seemann M, et al. Isoprenoid biosynthesis as a novel target for antibacterial and antiparasitic drugs. Curr Opin Investig Drugs. 2004;5(2):154-62.

Roos DS, Crawford M J, Donald RG, et al. Mining the Plasmodium genome database to define organellar function: what does the apicoplast do? Philos Trans R Soc Lond B Biol Sci. 2002;357(1417):35-46. 
Russell RG, Watts NB, Ebetino FH, et al. Mechanisms of action of bisphosphonates: similarities and differences and their potential influence on clinical efficacy. Osteoporos Int. 2008;19(6):733-59.

Sanchez CP, Dave A, Stein WD, et al. Transporters as mediators of drug resistance in Plasmodium falciparum. Int J Parasitol. 2010;40(10):1109-18.

Sanders JM, Gomez AO, Mao J, et al. 3-D QSAR investigations of the inhibition of Leishmania major farnesyl pyrophosphate synthase by bisphosphonates. J Med Chem. 2003;46(24):5171-83.

Sanmiya K, Ueno O, Matsuoka M, et al. Localization of farnesyl diphosphate synthase in chloroplasts. Plant Cell Physiol. 1999;40(3):348-54.

Sato S, Tews I, Wilson RJ. Impact of a plastid-bearing endocytobiont on apicomplexan genomes. Int J Parasitol. 2000;30(4):427-39.

Schmidt A, Wachtler B, Temp U, et al. A bifunctional geranyl and geranylgeranyl diphosphate synthase is involved in terpene oleoresin formation in Picea abies. Plant Physiol. 2010;152(2):639-55.

Shen PS, Sanford JC, Samuelson J. Entamoeba histolytica: isoprenylation of p21ras and p21rap in vitro. Exp Parasitol. 1996;82(1):65-8.

Singh AP, Zhang Y, No JH, et al. Lipophilic bisphosphonates are potent inhibitors of Plasmodium liver-stage growth. Antimicrob Agents Chemother. 2010;54(7):2987-93.

Song L, Poulter CD. Yeast farnesyl-diphosphate synthase: site-directed mutagenesis of residues in highly conserved prenyltransferase domains I and II. Proc Natl Acad Sci U S A. 1994;91(8):3044-8.

Spurgeon SL, Porter JW. Biosynthesis of Isoprenoid Compounds. Wiley, New York; 1981. 146.

Stresing V, Daubine F, Benzaid I, et al. Bisphosphonates in cancer therapy. Cancer Lett. 2007;257(1):16-35.

SUS. Situação epidemiológica da Malária, Sistema Único de Sáude. 2012. Disponivel: from http://portal.saude.gov.br/portal/saude/profissional/visualizar_texto.cfm?idtxt=31086\&janela= 2.[15 ago 2012].

Sussmann RA, Angeli CB, Peres VJ, et al. Intraerythrocytic stages of Plasmodium falciparum biosynthesize vitamin E. FEBS Lett. 2011;585(24):3985-91.

Tarshis LC, Proteau PJ, Kellogg BA, et al. Regulation of product chain length by isoprenyl diphosphate synthases. Proc Natl Acad Sci U S A. 1996;93(26):15018-23.

Tarshis LC, Yan M, Poulter CD, et al. Crystal structure of recombinant farnesyl diphosphate synthase at 2.6-A resolution. Biochemistry. 1994;33(36):10871-7. 
Teclebrhan H, Olsson J, Swiezewska E, et al. Biosynthesis of the side chain of ubiquinone:trans-prenyltransferase in rat liver microsomes. $\mathrm{J}$ Biol Chem. 1993;268(31):23081-6.

Thelu J, Bracchi V, Burnod J, et al. Evidence for expression of a Ras-like and a stage specific GTP binding homologous protein by Plasmodium falciparum. Cell Signal. 1994;6(7):777-82.

Tonhosolo R, D'Alexandri F L, de Rosso V V, et al. Carotenoid biosynthesis in intraerythrocytic stages of Plasmodium falciparum. J Biol Chem. 2009;284(15):9974-85.

Tonhosolo R, D'Alexandri F L, Genta F A, et al. Identification, molecular cloning and functional characterization of an octaprenyl pyrophosphate synthase in intra-erythrocytic stages of Plasmodium falciparum. Biochem J. 2005;392(Pt 1):117-26.

Tonhosolo R, Gabriel HB, Matsumura MY, et al. Intraerythrocytic stages of Plasmodium falciparum biosynthesize menaquinone. FEBS Lett. 2010;584(23):4761-8.

Trager W, Jensen JB. Human malaria parasites in continuous culture. Science. 1976;193(4254):673-5.

Trang DT, Huy NT, Kariu T, et al. One-step concentration of malarial parasite-infected red blood cells and removal of contaminating white blood cells. Malar J. 2004;3:7.

Urbina JA, Moreno B, Vierkotter S, et al. Trypanosoma cruzi contains major pyrophosphate stores, and its growth in vitro and in vivo is blocked by pyrophosphate analogs. J Biol Chem. 1999;274(47):33609-15.

Van de Peer Y, Rensing SA, Maier UG, et al. Substitution rate calibration of small subunit ribosomal RNA identifies chlorarachniophyte endosymbionts as remnants of green algae. Proc Natl Acad Sci U S A. 1996;93(15):7732-6.

van Dooren GG, Waller RF, Joiner KA, et al. Traffic jams: protein transport in Plasmodium falciparum. Parasitol Today. 2000;16(10):421-7.

Vandermoten S, Charloteaux B, Santini S, et al. Characterization of a novel aphid prenyltransferase displaying dual geranyl/farnesyl diphosphate synthase activity. FEBS Lett. 2008;582(13):1928-34.

Vogelstein B, Gillespie D. Preparative and analytical purification of DNA from agarose. Proc Natl Acad Sci U S A. 1979;76(2):615-9.

Waller RF, Keeling PJ, Donald RG, et al. Nuclear-encoded proteins target to the plastid in Toxoplasma gondii and Plasmodium falciparum. Proc Natl Acad Sci U S A. 1998;95(21):12352-7.

Waller RF, McFadden GI. The apicoplast: a review of the derived plastid of apicomplexan parasites. Curr Issues Mol Biol. 2005;7(1):57-79. 
Wang K, Ohnuma S. Chain-length determination mechanism of isoprenyl diphosphate synthases and implications for molecular evolution. Trends Biochem Sci. 1999;24(11):44551.

Wang KC, Ohnuma S. Isoprenyl diphosphate synthases. Biochim Biophys Acta. 2000;1529(1-3):33-48.

WHO. World Malaria Reported: 2010. World Health Organization. 2010.

WHO. Guidelines for the treatment of malaria. World Health Organization, Switzerland. 2010a;Second edition:194.

WHO. World Malaria Reported. World Health Organization, Switzerland. 2010b:238.

WHO. World Malaria Reported. World Health Organization, Switzerland. 2011:250.

Wiesner J, Henschker D, Hutchinson DB, et al. In vitro and in vivo synergy of fosmidomycin, a novel antimalarial drug, with clindamycin. Antimicrob Agents Chemother. 2002;46(9):2889-94.

Wilson RJ. Progress with parasite plastids. J Mol Biol. 2002;319(2):257-74.

Wilson RJ, Denny P W, Preiser P R, et al. Complete gene map of the plastid-like DNA of the malaria parasite Plasmodium falciparum. J Mol Biol. 1996;261(2):155-72.

Wilson RJ, Williamson DH. Extrachromosomal DNA in the Apicomplexa. Microbiol Mol Biol Rev. 1997;61(1):1-16.

Yardley V, Khan AA, Martin MB, et al. In vivo activities of farnesyl pyrophosphate synthase inhibitors against Leishmania donovani and Toxoplasma gondii. Antimicrob Agents Chemother. 2002;46(3):929-31.

Yeh E and DeRisi JL. Chemical rescue of malaria parasites lacking an apicoplast defines organelle function in blood-stage Plasmodium falciparum. PLoS Biol. 2011;9(8):e1001138.

Zhang B, Watts KM, Hodge D, et al. A second target of the antimalarial and antibacterial agent fosmidomycin revealed by cellular metabolic profiling. Biochemistry. 2011;50(17):3570-7.

Zhang D, Poulter CD. Analysis and purification of phosphorylated isoprenoids by reversedphase HPLC. Anal Biochem. 1993;213(2):356-61.

Zhang FL, Casey PJ. Protein prenylation: molecular mechanisms and functional consequences. Annu Rev Biochem. 1996;65:241-69.

Zhang Y, Cao R, Yin F, et al. Lipophilic bisphosphonates as dual farnesyl/geranylgeranyl diphosphate synthase inhibitors: an X-ray and NMR investigation. J Am Chem Soc. 2009;131(14):5153-62. 
APÊNDICE A - In vitro and in vivo antiplasmodial activies of risedronate and its interference with protein prenylation in Plasmodium falciparum 


\title{
In Vitro and In Vivo Antiplasmodial Activities of Risedronate and Its Interference with Protein Prenylation in Plasmodium falciparum ${ }^{\nabla} \dagger$
}

\author{
Fabiana Morandi Jordão, Alexandre Yukio Saito, Danilo Ciccone Miguel, Valnice de Jesus Peres, \\ Emília Akemi Kimura, and Alejandro Miguel Katzin* \\ Department of Parasitology, Institute of Biomedical Sciences, University of São Paulo, São Paulo, Brazil
}

Received 27 December 2010/Returned for modification 4 January 2011/Accepted 22 February 2011

\begin{abstract}
The increasing resistance of malarial parasites to almost all available drugs calls for the identification of new compounds and the detection of novel targets. Here, we establish the antimalarial activities of risedronate, one of the most potent bisphosphonates clinically used to treat bone resorption diseases, against blood stages of Plasmodium falciparum (50\% inhibitory concentration $\left[\mathrm{IC}_{50}\right]$ of $\left.20.3 \pm 1.0 \mu \mathrm{M}\right)$. We also suggest a mechanism of action for risedronate against the intraerythrocytic stage of $P$. falciparum and show that protein prenylation seems to be modulated directly by this drug. Risedronate inhibits the transfer of the farnesyl pyrophosphate group to parasite proteins, an effect not observed for the transfer of geranylgeranyl pyrophosphate. Our in vivo experiments further demonstrate that risedronate leads to an $88.9 \%$ inhibition of the rodent parasite Plasmodium berghei in mice on the seventh day of treatment; however, risedronate treatment did not result in a general increase of survival rates.
\end{abstract}

Malaria is the leading cause of morbidity and mortality in tropical regions, with 300 to 500 million clinical cases and around 1 million deaths a year (40). Plasmodium falciparum is responsible for the most severe form of the disease. Malaria expansion in some areas has been attributed to the failure of vector control policies and, mainly, to the increase of parasite resistance to drugs commonly used for its therapy (33). This alarming scenario has accelerated research into new antimalarial drugs, focusing efforts on the study not only of conventional but also of novel targets, such as isoprenoid biosynthesis (41). Isoprenoids are abundant and diverse compounds widely distributed in nature, and many of them (e.g., retinoids, carotenoids, ubiquinones, dolichols, and prenyl groups bound to proteins) are essential components of the cellular machinery of all organisms due to their roles in a plethora of biological processes (39).

All isoprenoids are derived from a common precursor, isopentenyl pyrophosphate (IPP), and its isomer, dimethylallyl pyrophosphate (DMAPP). Farnesyl pyrophosphate synthase (FPPS) catalyzes the consecutive condensation of IPP with DMAPP and geranyl pyrophosphate (GPP) to produce farnesyl pyrophosphate (FPP). FPP biosynthesis is considered the branching point in the isoprenoid synthesis pathway, since it is the substrate for enzymes that catalyze the first committed step for the biosynthesis of diverse isoprenoids. FPP can also be condensed with an additional molecule of IPP to yield geranylgeranyl pyrophosphate (GGPP), a reaction catalyzed by geranylgeranyl pyrophosphate synthase (GGPPS) (17).

FPP and GGPP are substrates for prenyl:protein trans-

\footnotetext{
* Corresponding author. Mailing address: Department of Parasitology, Institute of Biomedical Sciences, University of São Paulo, Av. Professor Lineu Prestes 1374, CEP 05508-000, São Paulo, SP, Brazil. Phone: 55-11-3091-7330. Fax: 55-11-3091-7417. E-mail: amkatzin@icb .usp.br.

$\dagger$ Supplemental material for this article may be found at http://aac .asm.org/.

${ }^{\nabla}$ Published ahead of print on 28 February 2011.
}

ferases (farnesyl transferase and geranylgeranyl transferase), catalyzing the posttranslational modification of proteins (6). Protein prenylation is a general pathway in eukaryotic cells and has been described for several protozoan parasites $(12,19,26$, $34,44)$, including $P$. falciparum (5). In addition, our group has characterized farnesylated and geranylgeranylated proteins in $P$. falciparum and showed that prenylation can be inhibited by terpenes (30). The process of protein prenylation is a very attractive goal for the development of new drugs targeting malignant cells and protozoan parasites $(4,16)$.

Bisphosphonates are potent inhibitors of bone resorption and are in clinical use for the treatment and prevention of osteoporosis, Paget's disease, hypercalcemia caused by malignancy, and tumor metastasis in bone (29), and it is promising as an antibacterial, anticancer, and antiparasitic drug (10, 32, 36). In vitro and in vivo antiparasitic effects of bisphosphonates against Leishmania mexicana, Leishmania donovani, Trypanosoma cruzi, Trypanosoma brucei, Cryptosporidium parvum, Toxoplasma gondii, and $P$. falciparum have been established $(10,15,24,27,31,38,42)$. Recently, it was demonstrated that "lipophilic" bisphosphonates are effective against Plasmodium liver stages (35). Specifically, nitrogen-containing bisphosphonates (N-BPs) have been developed to be employed in the treatment of bone diseases, targeting FPPS. N-BPs prevent the posttranslational prenylation of proteins in $\mathbf{J} 774$ macrophages (25) and osteoclasts in vitro by inhibiting FPPS $(8,13)$.

In this study, we characterized the in vitro and in vivo antiplasmodial activities of risedronate, a commercially available N-BP. Our results further confirm the inhibition of parasite protein prenylation as a possible mechanism of action for risedronate, as this drug decreased FPP and GGPP biosynthesis and inhibited FPP transfer to proteins.

\section{MATERIALS AND METHODS}

Reagents. Percoll was purchased from GE Healthcare. $\left[1-(n)-{ }^{3} \mathrm{H}\right]$ geranylgeranyl pyrophosphate triammonium salt $\left\{\left[1-(n)-{ }^{3} \mathrm{H}\right] \mathrm{GGPP}\right\}(16.5 \mathrm{Ci} / \mathrm{mmol}),[1-(n)-$ 
$\left.{ }^{3} \mathrm{H}\right]$ farnesyl pyrophosphate triammonium salt $\left\{\left[1-(n)-{ }^{3} \mathrm{H}\right] \mathrm{FPP}\right\}(16.5 \mathrm{Ci} / \mathrm{mmol})$, and $\left[1-{ }^{14} \mathrm{C}\right]$ isopentenyl pyrophosphate triammonium salt $\left(\left[{ }^{14} \mathrm{C}\right] \mathrm{IPP}\right)(55.0 \mathrm{Ci} /$ mmol) were obtained from GE Healthcare. Life Technologies supplied Albumax I. Sigma-Aldrich provided isopentenyl pyrophosphate (IPP), farnesyl pyrophosphate ammonium salt (FPP), geranylgeranyl pyrophosphate ammonium salt (GGPP), farnesol (FOH), and geranylgeraniol (GGOH). Risedronate was purchased from Gerbrás Química Farmacêutica (Brazil).

Plasmodium falciparum culture. P. falciparum clone 3D7 was cultured according to a protocol described previously by Trager and Jensen (37), where human serum was replaced by Albumax I (0.5\%) (21). Parasites were grown in a 40-ml volume in an atmosphere of $5 \% \mathrm{CO}_{2}, 5 \% \mathrm{O}_{2}$, and $90 \% \mathrm{~N}_{2}$. The cultures were initially synchronized in the ring stage ( 1 to $20 \mathrm{~h}$ after reinvasion) by two treatments with $5 \%(\mathrm{wt} / \mathrm{vol}) \mathrm{D}$-sorbitol solution in water for subsequent maintenance in culture until the differentiation to the trophozoite $(20$ to $30 \mathrm{~h}$ after reinvasion) or schizont (30 to $35 \mathrm{~h}$ after reinvasion) stage. Parasite development and multiplication were monitored by the microscopic evaluation of Giemsastained thin smears.

Inhibition tests with risedronate and rescue assays. Risedronate was dissolved in sterile deionized water, resulting in a $25 \mathrm{mM}$ stock solution. The inhibition tests were carried out with flat-bottomed microtiter plates using the following drug concentrations: $3,000,300,30,3,0.3,0.03$, and $0.003 \mu \mathrm{M}$. We employed a method described previously by Desjardins and coauthors (9), with some modifications, to determine risedronate $50 \%$ inhibitory concentrations $\left(\mathrm{IC}_{50} \mathrm{~s}\right)$ for P. falciparum intraerythrocytic stages after $48 \mathrm{~h}$ of treatment. Briefly, synchronic ring-stage parasite cultures (5\% hematocrit and $1 \%$ parasitemia) were exposed to increasing drug concentrations, and the parasitemia and parasite morphologies were determined with Giemsa-stained smears immediately before the start and at intervals of 24 to $96 \mathrm{~h}$, instead of $\left[{ }^{3} \mathrm{H}\right]$ hypoxanthine incorporation. All tests were performed in triplicates for three independent experiments. The $\mathrm{IC}_{50}$, $\mathrm{IC}_{90}$ ( \pm standard deviation), and $95 \%$ confidence interval $\left(\mathrm{CI}_{95 \%}\right)$ values for growth inhibition were calculated by using Origin 8.1 software (OriginLab). For the rescue assays, FPP, GGPP, and IPP were solubilized in RPMI medium (5 $\mathrm{mM}$ stock solution), and different concentrations of each compound (100 nM to $1,000 \mathrm{nM}$ ) were then added simultaneously to synchronous $P$. falciparum cultures in the ring stage previously treated with $20 \mu \mathrm{M}$ risedronate. Parasitemia was assessed every $24 \mathrm{~h}$. Statistical analysis was performed by using one-way analysis of variance (ANOVA) followed by Dunnett's post hoc test (GraphPad Prism, CA). A $P$ value of $<0.05$ was considered statistically significant.

Treatment with risedronate and metabolic labeling. Asynchronous cultures of P. falciparum were treated with $15 \mu \mathrm{M}$ risedronate for $36 \mathrm{~h}$ and labeled with $\left[1{ }^{3} \mathrm{H}\right]$ GGPP $(3.125 \mu \mathrm{Ci} / \mathrm{ml})$ or $\left[1{ }^{3} \mathrm{H}\right] \mathrm{FPP}(3.125 \mu \mathrm{Ci} / \mathrm{ml})$ in normal RPMI 1640 medium for the last $12 \mathrm{~h}$ in the presence of drug. After labeling, ring, trophozoite, and schizont forms were purified on a $40 \%-70 \%-80 \%$ discontinuous Percoll gradient (3), followed by cell lysis in a solution containing ice-cold $10 \mathrm{mM}$ Tris- $\mathrm{HCl}(\mathrm{pH} 7.2), 150 \mathrm{mM} \mathrm{NaCl}, 2 \%$ (vol/vol) Triton X-100, $0.2 \mathrm{mM}$ phenylmethylsulfonyl fluoride (PMSF), $5 \mathrm{mM}$ iodoacetamide, $1 \mathrm{mM} N$-( $p$-tosyllysine)chloromethyl ketone, and $1 \mu \mathrm{g} / \mathrm{ml}$ leupeptin (TEN-Triton). After incubation for $15 \mathrm{~min}$ at $4^{\circ} \mathrm{C}$, lysates were centrifuged at $10,000 \times g$ for $30 \mathrm{~min}$. Supernatants of parasites were stored in liquid $\mathrm{N}_{2}$ for subsequent SDS-PAGE analysis. For the analysis of isoprenoids, synchronic cultures in the ring stage were treated with $15 \mu \mathrm{M}$ risedronate for $36 \mathrm{~h}$ and metabolically labeled with $\left[1-{ }^{14} \mathrm{C}\right] \mathrm{IPP}$ for the last $12 \mathrm{~h}$. After labeling, schizont-stage parasites were purified on a 40\%-70\%-80\% discontinuous Percoll gradient as described above and freeze-dried prior to lipid extraction as described elsewhere previously (30). Risedronate at $15 \mu \mathrm{M}$ was considered the ideal drug concentration to be used in our metabolic labeling experiments, since approximately $90 \%$ of the parasite population remained viable after $36 \mathrm{~h}$ of treatment.

Reverse-phase thin-layer chromatography (RP-TLC). Similar amounts of schizont-stage pellets of untreated or risedronate-treated parasites labeled with [1${ }^{14} \mathrm{C}$ IIPP as described above were extracted with hexane for the subsequent separation of alcohols on reverse-phase Silica Gel 60 plates (Merck) with acetone- $\mathrm{H}_{2} \mathrm{O}(6: 1, \mathrm{vol} / \mathrm{vol})(23)$. Plates were sprayed with En ${ }^{3} \mathrm{Hance}$ (DuPont NEN) and subjected to autoradiography for 45 days at $-70^{\circ} \mathrm{C}$. The standards were visualized with iodine vapor, and $R_{f}$ values were determined. Hexane extracts of uninfected erythrocytes were used as a control group.

Gel electrophoresis. SDS-PAGE was performed with $12.5 \%$ gels as described elsewhere previously (22). The same numbers of drug-treated or untreated parasites labeled with $\left[1-{ }^{3} \mathrm{H}\right] \mathrm{GGPP}$ or $\left[1-{ }^{3} \mathrm{H}\right] \mathrm{FPP}$ were extracted in TEN-Triton and solubilized in SDS sample buffer $(50 \mathrm{mM}$ Tris- $\mathrm{HCl}[\mathrm{pH}$ 6.8], $100 \mathrm{mM}$ dithiothreitol, $2 \%$ SDS, $0.1 \%$ bromophenol blue, $10 \%$ glycerol) and applied onto each well for protein extract analyses. All gels were incubated with Amplify (Amersham), dried, and exposed to Kodak X-Omat film with intensifying screen sets at $-70^{\circ} \mathrm{C}$ for 30 days.
Immunoprecipitation assays. Synchronic cultures in the ring stage were treated with $15 \mu \mathrm{M}$ risedronate for $24 \mathrm{~h}$ and metabolically labeled with [1$\left.{ }^{3} \mathrm{H}\right] \mathrm{FPP}$ or $\left[1-{ }^{3} \mathrm{H}\right]$ GGPP for an additional $12 \mathrm{~h}$ in the presence of the drug. After labeling, schizont-stage parasites were purified on a $40 \%-70 \%-80 \%$ discontinuous Percoll gradient as described above. Pellets of untreated and treated schizont-stage parasites were resuspended in immunoprecipitation buffer $(50 \mathrm{mM}$ Tris- $\mathrm{HCl}$ [pH 8.0], $150 \mathrm{mM} \mathrm{NaCl}, 1 \%$ [vol/vol] Triton X-100, $0.5 \%$ [wt/vol] sodium deoxycholate, $0.1 \%$ [wt/vol] SDS, $5 \mu \mathrm{g} / \mathrm{ml}$ protease inhibitor cocktail [0.2 $\mathrm{mM}$ phenylmethylsulfonyl fluoride, $1 \mathrm{mM}$ benzamidine, $2 \mathrm{mM} \beta$-mercaptoethanol, chymostatin $\{5 \mathrm{mg} / \mathrm{ml}\}$, and $1 \mu \mathrm{g} / \mathrm{ml}$ leupeptin, antipain, and pepstatin A]) and then precleared with protein A-Sepharose beads (GE Healthcare) (28) Schizont forms were then incubated with anti-human Ras or anti-Rap1/Krev-1 monoclonal immunoglobulins (1:20 dilution; Cell Signaling Technology) for $2 \mathrm{~h}$ at $4^{\circ} \mathrm{C}$. The antigen-antibody complex was precipitated by using $100 \mu \mathrm{l}$ of a $10 \%$ protein A-Sepharose slurry. After five washes with phosphate-buffered saline (PBS), the bound antigen was released in SDS sample buffer and analyzed by SDS-PAGE and autoradiography (20). Densitometric analyses were performed by using Image $\mathbf{J}$ software (National Institutes of Health).

In vivo assays. Each male BALB/c mouse ( 3 to 4 weeks old) $(n=10$ to 15 per group) was injected intraperitoneally (i.p.) with $10^{6}$ blood-stage Plasmodium berghei strain ANKA parasites. Our laboratory previously established this parasite burden as the $50 \%$ lethal dose 14 days after inoculation. Risedronate treatment with different concentrations was initiated in $2 \mathrm{~h}$ after infection on day 0 and continued for 7 days. The drug was diluted in PBS and administered i.p. at $10,15,20$, and $25 \mathrm{mg} / \mathrm{kg}$ of body weight/day. Parasitemia levels were monitored microscopically by examining Giemsa-stained thin blood smears on days 4, 7, 11, 14, and 17 postinfection. Throughout this period, the spontaneous death of each animal was computed. The percentage of parasitemia inhibition was calculated as follows: $100-[($ mean parasitemia for the treated group/mean parasitemia for the control group) $\times 100](14)$. For comparisons of average parasitemias at different time points, analysis of variance was performed with a post hoc MannWhitney test for comparisons of the means (Origin 8.1 software; OriginLab). All in vivo assays were approved by the Ethics Committee for Animal Experimentation of the Instituto de Ciências Biomédicas, University of São Paulo.

\section{RESULTS}

Inhibition of $\boldsymbol{P}$. falciparum development after treatment with risedronate. To test the inhibitory effect of risedronate on $P$. falciparum growth, parasites were cultured in the absence or presence of increasing concentrations of the drug. The growth of parasites was inhibited in a dose-dependent manner with an $\mathrm{IC}_{50}$ of $20.3 \pm 1.0 \mu \mathrm{M}\left(\mathrm{CI}_{95 \%}, 19.17\right.$ to $21.43 ; \mathrm{IC}_{90}, 38.6 \pm 0.9$ $\mu \mathrm{M})$. The inhibitory effect of risedronate was reverted by the simultaneous addition of FPP or GGPP at $1 \mu \mathrm{M}$ during $48 \mathrm{~h}$ of treatment $(88.3 \% \pm 9.1 \%$ and $83.5 \% \pm 9.8 \%$ of growth, respectively). When IPP, an upstream precursor of FPP, was incubated under the same experimental conditions, the inhibitory effect of risedronate was not reversed, validating the hypothesis that FPPS is a potential target of risedronate (Fig. 1).

Effect of risedronate on the biosynthesis of $P$. falciparum isoprenoids. To determine the effect of risedronate on isoprenoid biosynthesis, parasites were metabolically labeled with $\left[1-{ }^{14} \mathrm{C}\right] \mathrm{IPP}$, and lipid extracts of schizont-stage parasites for untreated and treated parasites $(15 \mu \mathrm{M}$ risedronate for $36 \mathrm{~h})$ were analyzed by RP-TLC (Fig. 2). $\left[1-{ }^{14} \mathrm{C}\right]$ IPP incorporation into isoprenoids was inhibited in risedronate-treated schizontstage parasites, as the intensities of bands with $R_{f}$ values corresponding to farnesol $(\mathrm{FOH})$ and geranylgeraniol $(\mathrm{GGOH})$ standards were decreased. The intensities of bands with $R_{f}$ values equivalent to prenol of 8 and 9 isoprenic chains were also reduced.

Risedronate interferes with Plasmodium protein isoprenylation. Given that FOH and GGOH biosyntheses were clearly inhibited after risedronate treatment, one could speculate that 


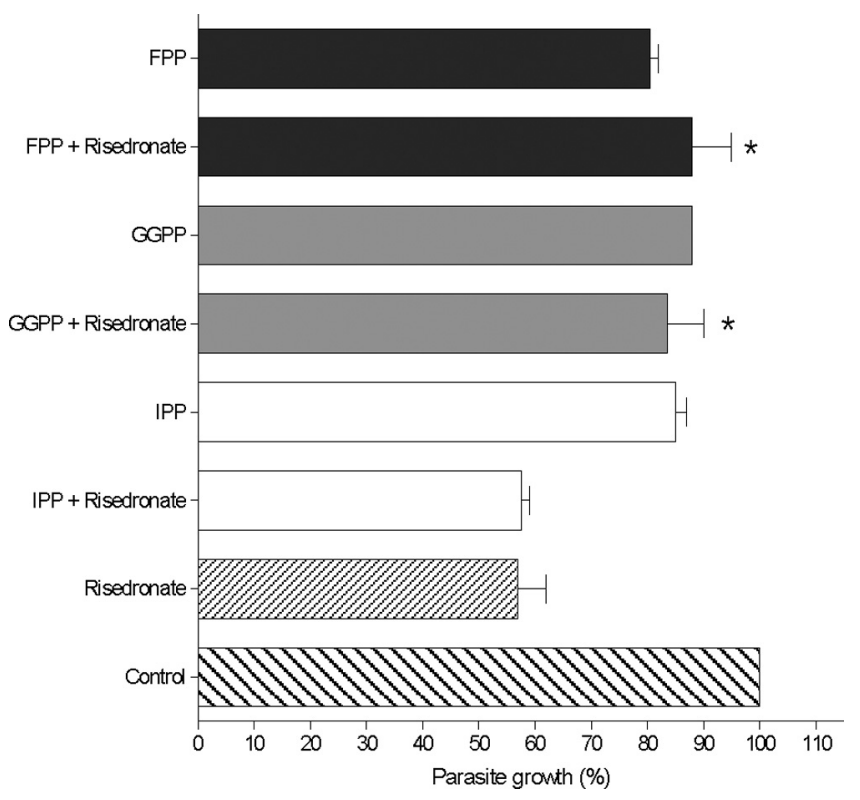

FIG. 1. Effect of a 48-h risedronate treatment on the growth of $P$. falciparum. Parasite growth inhibition by risedronate $(55.2 \% \pm$ $7.1 \%$ ) was partially reversed by the addition of FPP $(88.3 \% \pm 9.1 \%)$ or GGPP $(83.5 \% \pm 9.8 \%)$ to a final concentration of $1,000 \mathrm{nM}$ in parasite cultures. The addition of IPP did not reverse the inhibition. Parasite growth percentages when FPP, GGPP, or IPP was added alone in parasite culture were not statistically different from those of the parasite control. One-way analysis of variance with Dunnett's multiplecomparison test was used to determine statistical differences $(*)$ between FPP plus risedronate versus risedronate $(P<0.05)$ and between GGPP plus risedronate versus risedronate $(P<0.01)$. Results are expressed as the means of parasite growth (percent) \pm standard deviations from three independent experiments.

one of the effects of risedronate is probably related to its interference with the protein isoprenylation process. To test this hypothesis, we labeled parasites with $\left[1-{ }^{3} \mathrm{H}\right] \mathrm{FPP}$ or $[1-$ $\left.{ }^{3} \mathrm{H}\right] \mathrm{GGPP}$ in order to analyze protein extracts by SDS-PAGE. When ring- and schizont-stage parasites were treated with 15 $\mu \mathrm{M}$ risedronate and then labeled with $\left[1-{ }^{3} \mathrm{H}\right] \mathrm{FPP}$, we observed significant differences in the incorporation of this precursor into proteins. The intensities of bands presenting molecular masses of around 51, 41, 27 to 29 , and $7 \mathrm{kDa}$ decreased. Interestingly, trophozoite-stage parasites presented almost all the farnesylated proteins inhibited (except for the 7-kDa band) after incubation with risedronate (Fig. 3A). In contrast, when parasites were treated with the drug and labeled with $\left[1-{ }^{3} \mathrm{H}\right] \mathrm{GGPP}$, bands with an apparent molecular mass of 27 to $29 \mathrm{kDa}$ showed an increase of intensity for all stages evaluated (Fig. 3B). Noninfected red blood cells showed no incorporation of radioactivity under these conditions (data not shown). In order to evaluate whether risedronate specifically alters p $21^{\text {ras }}$ and $\mathrm{p} 21^{\text {rap }}$ in $P$. falciparum protein lysates, untreated and risedronate-treated schizont forms previously labeled with $\left[1-{ }^{3} \mathrm{H}\right] \mathrm{FPP}$ or $\left[1-{ }^{3} \mathrm{H}\right] \mathrm{GGPP}$ were immunoprecipitated with anti-p $21^{\text {ras }}$ or anti-p21 $1^{\text {rap }}$ antibodies, respectively. Compared to the control group, Ras-like protein levels in schizont-stage parasites were reduced approximately 2 -fold after treatment with risedronate. On the other hand, an increase of 3.8-fold versus the control group was detected for a band of

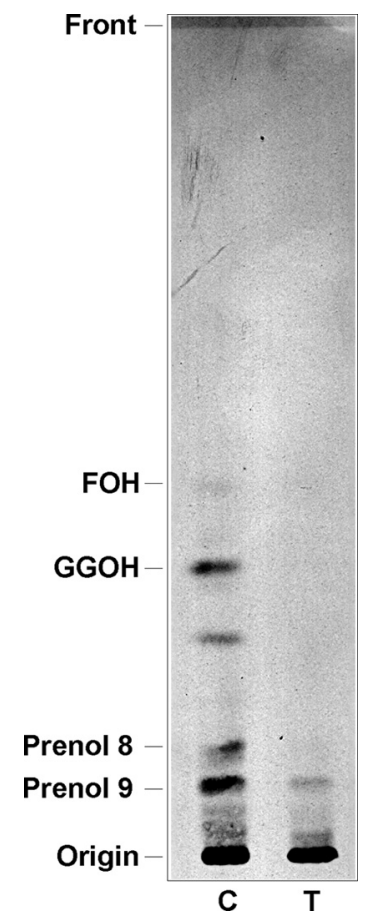

FIG. 2. RP-TLC analysis of hexane extract schizont-stage $P$. falciparum parasites. Parasites were untreated and treated for $36 \mathrm{~h}$ with 15 $\mu \mathrm{M}$ risedronate and then metabolically labeled for the last $12 \mathrm{~h}$ with $\left[1-{ }^{14} \mathrm{C}\right] \mathrm{IPP}$. The solvent system was acetone- $\mathrm{H}_{2} \mathrm{O}(6: 1, \mathrm{vol} / \mathrm{vol})$. Abbreviations: $\mathrm{C}$, control; $\mathrm{T}$, risedronate-treated parasites; $\mathrm{FOH}$, farnesol; GGOH, geranylgeraniol.

$21 \mathrm{kDa}$ corresponding to Rap-like proteins in treated parasites (Fig. 3C). Taken together, these results reinforce that risedronate modulates the incorporation of $\left[1-{ }^{3} \mathrm{H}\right] \mathrm{FPP}$ and $\left[1-{ }^{3} \mathrm{H}\right] \mathrm{GGPP}$ into parasite proteins in an opposite manner.

In vivo effect of risedronate. After determining the antiplasmodial effect of risedronate in vitro, we verified its efficacy in BALB/c mice infected with $P$. berghei strain ANKA. The administration of 20 and $25 \mathrm{mg} / \mathrm{kg}$ risedronate for 4 days led to decreases of parasitemia of $68.9 \%$ and $83.6 \%$, respectively. On the seventh day of treatment the inhibitions were $63 \%$ and $88.9 \%$ with 20 and $25 \mathrm{mg} / \mathrm{kg}$, respectively (Fig. 4A). After recovering the parasitemia, a dose-response curve was obtained for estimating the ID $_{50}$ (dose causing 50\% inhibition), equivalent to $17 \pm 1.8 \mathrm{mg} / \mathrm{kg}$ after 7 days of treatment. Four days after the interruption of treatment (11 days postinfection), the parasitemias of the groups treated with 10, 15, 20, and $25 \mathrm{mg} / \mathrm{kg} /$ day were $15.3 \%, 15.9 \%, 15.2 \%$, and $5.7 \%$, respectively. Conversely, the group that received PBS presented parasitemia of $25.6 \%$. Among the groups treated with risedronate, only the animals that received $25 \mathrm{mg} / \mathrm{kg}$ had a significant inhibition of $77.8 \%$ (see Table S1 in the supplemental material), demonstrating that even after treatment discontinuation, the parasitemia of the animals remained low in relation to that of the controls; however, parasite recrudescence was observed for all treated groups. By Kaplan-Meier survival analysis there was no difference between risedronate-treated mice and PBStreated groups (Fig. 4B). 

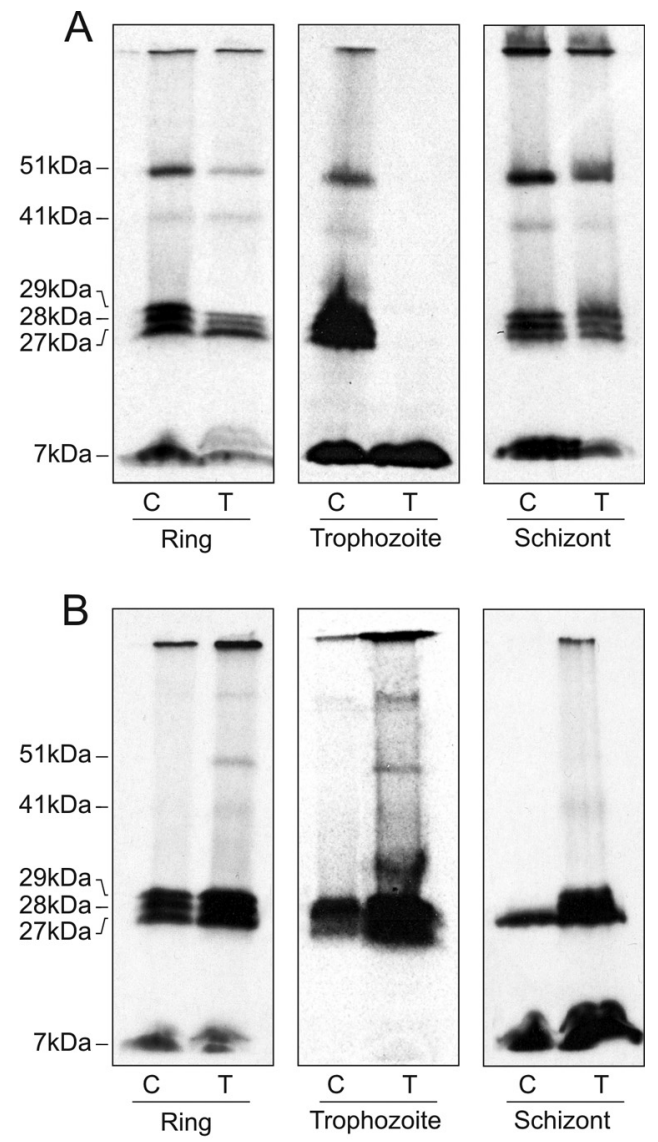

C

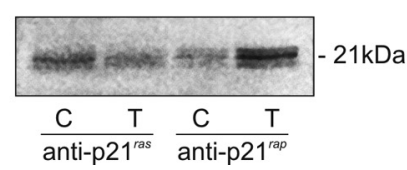

FIG. 3. In vitro treatment of $P$. falciparum cultures with risedronate and metabolic labeling with $\left[1-{ }^{3} \mathrm{H}\right] \mathrm{GGPP}$ or $\left[1-{ }^{3} \mathrm{H}\right] \mathrm{FPP}$. (A and B) Parasites were untreated or treated for $36 \mathrm{~h}$ with $15 \mu \mathrm{M}$ risedronate and labeled for the last $12 \mathrm{~h}$ with $\left[1-{ }^{3} \mathrm{H}\right] \mathrm{FPP}(\mathrm{A})$ or $\left[1-{ }^{3} \mathrm{H}\right] \mathrm{GGPP}(\mathrm{B})$. (C) Immunoprecipitation using anti-p21 ras or anti-p21 rap antibody with schizont-stage parasites metabolically labeled with $\left[1-{ }^{3} \mathrm{H}\right] \mathrm{FPP}$ or $[1-$ $\left.{ }^{3} \mathrm{H}\right]$ GGPP, respectively. The parasites were harvested and purified by Percoll gradients, lysed, and analyzed by SDS-PAGE and fluorography. The parasite stage analyzed is indicated at the bottom of each panel (ring, trophozoite, and schizont forms). Molecular mass standards are indicated on the left $(\mathrm{kDa})$. C, control; $\mathrm{T}$, risedronatetreated parasites. This is a representative experiment of three independent assays.

\section{DISCUSSION}

In this report we confirmed that risedronate, a nitrogencontaining bisphosphonate (N-BP), has a potent activity against the blood stages of $P$. falciparum in vitro and $P$. berghei in vivo. The $\mathrm{IC}_{50}$ established for parasite growth is in the range obtained for the same isolate (3D7) in previous studies (27, $35)$. We also showed that the inhibitory effect induced by risedronate can be partially reversed by the simultaneous addition of FPP or GGPP during P. falciparum culture treatment (Fig. 1). The restoration observed after the addition of GGPP is plausible, since Couto et al. (7) previously demonstrated that
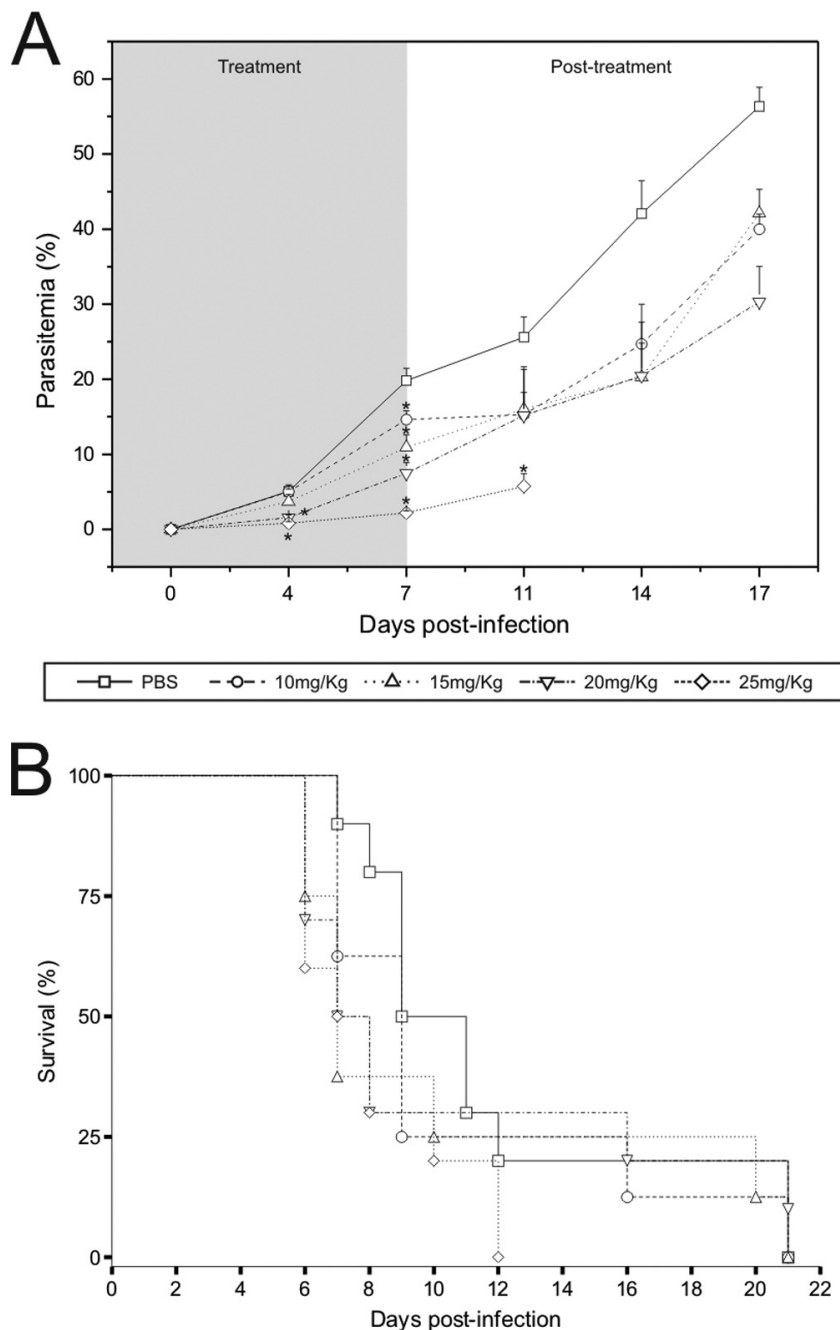

FIG. 4. Effect of risedronate on mice infected with $P$. berghei erythrocytic-stage parasites. Mice were infected by the intraperitoneal injection of $1 \times 10^{6}$ Plasmodium berghei ANKA-parasitized murine erythrocytes and treated with PBS or different doses of risedronate i.p. for 7 days. (A) Parasitemia was monitored on days 4, 7, 11, 14, and 17 after infection. Each time point represents the means \pm standard errors, and asterisks indicate significant differences between PBS- and risedronate-treated groups. A Mann-Whitney test was used to evaluate statistic differences between groups, and a $P$ value of $<0.05$ were considered statistically significant ( $n=10$ per group). (B) Mortality was checked daily, and survival curves were plotted according to Kaplan-Meier analysis using GraphPad Prism 5 (GraphPad Software, CA). Differences between groups were evaluated by a log-rank test, but there were no significant differences between groups $(P>0.07$ $n=15$ per group).

P. falciparum is able to convert GGPP into FPP. In contrast, when we added IPP to the cultures, the parasites could not recover, suggesting that the inhibition of FPPS is a potential target for risedronate, which could also act by inhibiting GGPPS. Luckman et al. (25) verified the same event of restoration after coincubating J774 macrophages with alendronate and FPP or GGPP, observing a partial prevention of apoptotic events.

Our results regarding the effect of risedronate on isoprenoid biosynthesis (Fig. 2) suggest the inhibition of FPPS. The RP- 
TLC profile for treated parasites shows that bands with $R_{f}$ values equivalent to $\mathrm{FOH}$ and $\mathrm{GGOH}$ are decreased compared to the signal from untreated parasites, leading us to speculate that risedronate inhibits enzymes involved in FPP and/or GGPP synthesis. It is known that the major target of $\mathrm{N}-\mathrm{BPs}$, as risedronate, is FPPS (11); therefore, we assume the possible role of risedronate as a potent inhibitor of the isoprenoid pathway in $P$. falciparum by inhibiting FPPS and, consequently, blocking protein farnesylation and geranylgeranylation. In J774 macrophages, the drug inhibited protein prenylation, including Ras protein prenylation (25).

These results are supported by the fact that several phosphonate and bisphosphonate analogues of FPP have been demonstrated to inhibit farnesyltransferase (18). Since risedronate inhibits FPP and GGPP biosynthesis, it is expected, in the case of treated and $\left[1-{ }^{3} \mathrm{H}\right] \mathrm{FPP}-$ and $\left[1-{ }^{3} \mathrm{H}\right] \mathrm{GGPP}-$ labeled parasites, to exhibit an increase of intensity in the bands corresponding to isoprenylated proteins. However, the profile of farnesylated proteins was decreased in intensity compared to the control group. This result could be explained by the inhibition of FPP transfer to proteins. On the other hand, the profile of geranylgeranylated proteins was increased in intensity, probably because the transfer of GGPP to proteins was not altered by risedronate. Moreover, this result shows either that risedronate inhibits $P$. falciparum GGPPS or that GGPP is inhibited as a result of the FPP suppression. Singh et al. (35) showed recently that lipophilic bisphosphonates have activity against a recombinant GGPPS from Plasmodium vivax. Recently, Artz et al. (1) showed that risedronate inhibits recombinant GGPPS from $P$. vivax using enzymatic activity assays and crystallography approaches. In $T$. gondii, N-BP was shown to inhibit the bifunctional enzyme FPPS/GGPPS (23). Considering that the Ras and Rab proteins are farnesylated and geranylgeranylated, respectively, the inhibition of Ras and increase of Rab after risedronate incubation (Fig. 3C) confirm our hypothesis that in $P$. falciparum, risedronate inhibits FPPS and the transfer of the FPP group to proteins.

Risedronate is indicated for the treatment and prevention of various bone diseases, such as osteoporosis in postmenopausal women, glucocorticoid-induced osteoporosis, and severe diseases like Paget's disease of bone (PDB). This is a chronic disorder for which treatment with oral risedronate at a dose of $17.5 \mathrm{mg}$ once daily for 8 weeks significantly decreases abnormal markers associated with PDB (43). Risedronate and other bisphosphonates possess antiprotozoal activity, specifically against Chagas' disease (2) and malaria. Recently, Singh et al. (35) studied the effect of lipophilic bisphosphonates (BPH-715) blocking the prenylation of proteins, resulting in a potent activity against $P$. berghei liver stages in vivo. Mice treated with BPH-715 showed complete protection, without the appearance of erythrocytic-stage parasites after 28 days of observation. However, this lipophilic bisphosphonate had only a mild inhibitory effect on erythrocytic stages of the parasite. Unlike the findings of Singh et al. (35), the bisphosphonate used in our experiments was effective in intraerythrocytic stages, where mice infected with $P$. berghei and treated with risedronate at $25 \mathrm{mg} / \mathrm{kg} /$ day for 7 days presented an $88.9 \%$ inhibition of parasitemia. It is noteworthy that in our in vivo studies, we determined the $\mathrm{ID}_{50}$ (dose causing $50 \%$ inhibition) of risedronate sodium, which was $17 \mathrm{mg} / \mathrm{kg} / \mathrm{day}$ for 7 days.
Even with the efficacy of risedronate in reducing parasitemia in erythrocytic stages, the survival of mice was not prolonged, suggesting that during treatment there was an inhibition of the development of Plasmodium berghei intraerythrocytic forms but no cure of infected animals. In a previous experiment, the animals that received risedronate over 7 days died unexpectedly on the ninth day postinfection, suggesting a possible toxic effect of the drug when associated with $P$. berghei infection. Curiously, when noninfected mice were treated for longer periods (14 days), risedronate did not show toxicity, since it was not lethal to the animals. Probably, the progressive asthenia caused by infection made the animals more susceptible and was a determining factor for the lethality despite the antiplasmodial activity of risedronate. For that reason, we decided to treat the infected mice for only 7 days and monitor them regarding their parasitemia and survival rates on the following days, thereby preventing the toxic effects of risedronate through extended periods of treatment. Our studies demonstrate that treatment with sodium risedronate exhibits significant in vivo antiplasmodial activity but also indicate a requirement for more investigation into the efficacy and safety of risedronate as therapy against malaria. Also, other ways of administration and other bisphosphonate-derived drugs should be evaluated.

In conclusion, our studies showed that risedronate interferes with farnesylated and geranylgernanylated proteins in $P$. falciparum as a consequence of the inhibition of the biosynthesis of FPP and GGPP. We also demonstrated that risedronate inhibits the transfer of FPP to parasite proteins. Additional experiments are required to assess the specificity of risedronate in the inhibition of protein farnesyltransferase in $P$. falciparum. These results suggest that the antiplasmodial activities of $\mathrm{N}$ BPs may be exploited as potential antimalarial candidates.

\section{ACKNOWLEDGMENTS}

This work was supported by grants from CNPq and FAPESP (Brazil). F.M.J. is the recipient of a postgraduate fellowship from CNPq A.Y.S. and D.C.M. receive postgraduate fellowships from FAPESP.

We thank S. Wendel (Sírio Libanês Hospital, NESTA) for providing the erythrocytes and Gerhard Wunderlich for critical reading of the manuscript.

\section{REFERENCES}

1. Artz, J. D., et al. 17 November 2010, posting date. Molecular characterization of a novel geranylgeranyl pyrophosphate synthase from Plasmodium parasites. J. Biol. Chem. doi:10.1074/jbc.M109.027235.

2. Bouzahzah, B., L. A. Jelicks, S. A. Morris, L. M. Weiss, and H. B. Tanowitz. 2005. Risedronate in the treatment of murine Chagas' disease. Parasitol. Res. 96:184-187.

3. Braun-Breton, C., et al. 1986. In vivo time course of synthesis and processing of major schizont membrane polypeptides in Plasmodium falciparum. Mol. Biochem. Parasitol. 20:33-43.

4. Chakrabarti, D., et al. 1998. Protein prenyl transferase activities of Plasmodium falciparum. Mol. Biochem. Parasitol. 94:175-184.

5. Chakrabarti, D., et al. 2002. Protein farnesyltransferase and protein prenylation in Plasmodium falciparum. J. Biol. Chem. 277:42066-42073.

6. Clarke, S. 1992. Protein isoprenylation and methylation at carboxyl-terminal cysteine residues. Annu. Rev. Biochem. 61:355-386.

7. Couto, A. S., E. A. Kimura, V. J. Peres, M. L. Uhrig, and A. M. Katzin. 1999 Active isoprenoid pathway in the intra-erythrocytic stages of Plasmodium falciparum: presence of dolichols of 11 and 12 isoprene units. Biochem. J. 341(Pt. 3):629-637.

8. Coxon, F. P., et al. 2000. Protein geranylgeranylation is required for osteoclast formation, function, and survival: inhibition by bisphosphonates and GGTI-298. J. Bone Miner. Res. 15:1467-1476.

9. Desjardins, R. E., C. J. Canfield, J. D. Haynes, and J. D. Chulay. 1979 Quantitative assessment of antimalarial activity in vitro by a semiautomated microdilution technique. Antimicrob. Agents Chemother. 16:710-718. 
10. Docampo, R., and S. N. Moreno. 2001. Bisphosphonates as chemotherapeutic agents against trypanosomatid and apicomplexan parasites. Curr. Drug Targets Infect. Disord. 1:51-61.

11. Dunford, J. E., et al. 2008. Structure-activity relationships among the nitrogen containing bisphosphonates in clinical use and other analogues: timedependent inhibition of human farnesyl pyrophosphate synthase. J. Med. Chem. 51:2187-2195.

12. Field, H., I. Blench, S. Croft, and M. C. Field. 1996. Characterisation of protein isoprenylation in procyclic form Trypanosoma brucei. Mol. Biochem. Parasitol. 82:67-80.

13. Frith, J. C., J. Monkkonen, S. Auriola, H. Monkkonen, and M. J. Rogers. 2001. The molecular mechanism of action of the antiresorptive and antiinflammatory drug clodronate: evidence for the formation in vivo of a metabolite that inhibits bone resorption and causes osteoclast and macrophage apoptosis. Arthritis Rheum. 44:2201-2210.

14. Gessler, M. C., M. H. Nkunya, L. B. Mwasumbi, M. Heinrich, and M. Tanner. 1994. Screening Tanzanian medicinal plants for antimalarial activity. Acta Trop. 56:65-77.

15. Ghosh, S., et al. 2004. Effects of bisphosphonates on the growth of Entamoeba histolytica and Plasmodium species in vitro and in vivo. J. Med. Chem. 47:175-187.

16. Gibbs, J. B., et al. 1996. Farnesyltransferase inhibitors and anti-Ras therapy. Breast Cancer Res. Treat. 38:75-83.

17. Goldstein, J. L., and M. S. Brown. 1990. Regulation of the mevalonate pathway. Nature 343:425-430.

18. Holstein, S. A., D. M. Cermak, D. F. Wiemer, K. Lewis, and R. J. Hohl. 1998. Phosphonate and bisphosphonate analogues of farnesyl pyrophosphate as potential inhibitors of farnesyl protein transferase. Bioorg. Med. Chem. 6:687-694

19. Ibrahim, M., N. Azzouz, P. Gerold, and R. T. Schwarz. 2001. Identification and characterisation of Toxoplasma gondii protein farnesyltransferase. Int. J. Parasitol. 31:1489-1497.

20. Kessler, S. W. 1975. Rapid isolation of antigens from cells with a staphylococcal protein A-antibody adsorbent: parameters of the interaction of antibody-antigen complexes with protein A. J. Immunol. 115:1617-1624.

21. Kimura, E. A., A. S. Couto, V. J. Peres, O. L. Casal, and A. M. Katzin. 1996 $\mathrm{N}$-linked glycoproteins are related to schizogony of the intraerythrocytic stage in Plasmodium falciparum. J. Biol. Chem. 271:14452-14461.

22. Laemmli, U. K. 1970 . Cleavage of structural proteins during the assembly of the head of bacteriophage T4. Nature 227:680-685.

23. Ling, Y., Z. H. Li, K. Miranda, E. Oldfield, and S. N. Moreno. 2007. The farnesyl-diphosphate/geranylgeranyl-diphosphate synthase of Toxoplasma gondii is a bifunctional enzyme and a molecular target of bisphosphonates. J. Biol. Chem. 282:30804-30816.

24. Ling, Y., et al. 2005. Bisphosphonate inhibitors of Toxoplasma gondii growth: in vitro, QSAR, and in vivo investigations. J. Med. Chem. 48:3130-3140.

25. Luckman, S. P., et al. 1998. Nitrogen-containing bisphosphonates inhibit the mevalonate pathway and prevent post-translational prenylation of GTPbinding proteins, including Ras. J. Bone Miner. Res. 13:581-589.

26. Lujan, H. D., M. R. Mowatt, G. Z. Chen, and T. E. Nash. 1995. Isoprenyla- tion of proteins in the protozoan Giardia lamblia. Mol. Biochem. Parasitol. 72:121-127.

27. Martin, M. B., et al. 2001. Bisphosphonates inhibit the growth of Trypanosoma brucei, Trypanosoma cruzi, Leishmania donovani, Toxoplasma gondii, and Plasmodium falciparum: a potential route to chemotherapy. J. Med. Chem. 44:909-916.

28. Moura, I. C., et al. 2001. Limonene arrests parasite development and inhibits isoprenylation of proteins in Plasmodium falciparum. Antimicrob. Agents Chemother. 45:2553-2558.

29. Rodan, G. A. 1998. Mechanisms of action of bisphosphonates. Annu. Rev. Pharmacol. Toxicol. 38:375-388.

30. Rodrigues Goulart, H., et al. 2004. Terpenes arrest parasite developmen and inhibit biosynthesis of isoprenoids in Plasmodium falciparum. Antimicrob. Agents Chemother. 48:2502-2509.

31. Rodriguez, N., et al. 2002. Radical cure of experimental cutaneous leishmaniasis by the bisphosphonate pamidronate. J. Infect. Dis. 186:138-140.

32. Rohmer, M., C. Grosdemange-Billiard, M. Seemann, and D. Tritsch. 2004 Isoprenoid biosynthesis as a novel target for antibacterial and antiparasitic drugs. Curr. Opin. Invest. Drugs 5:154-162.

33. Sanchez, C. P., A. Dave, W. D. Stein, and M. Lanzer. 2010. Transporters as mediators of drug resistance in Plasmodium falciparum. Int. J. Parasitol. 40:1109-1118.

34. Shen, P. S., J. C. Sanford, and J. Samuelson. 1996. Entamoeba histolytica: isoprenylation of p21ras and p21rap in vitro. Exp. Parasitol. 82:65-68.

35. Singh, A. P., et al. 2010. Lipophilic bisphosphonates are potent inhibitors of Plasmodium liver-stage growth. Antimicrob. Agents Chemother. 54:29872993.

36. Stresing, V., F. Daubine, I. Benzaid, H. Monkkonen, and P. Clezardin. 2007. Bisphosphonates in cancer therapy. Cancer Lett. 257:16-35.

37. Trager, W., and J. B. Jensen. 1976. Human malaria parasites in continuous culture. Science 193:673-675.

38. Urbina, J. A., et al. 1999. Trypanosoma cruzi contains major pyrophosphate stores, and its growth in vitro and in vivo is blocked by pyrophosphate analogs. J. Biol. Chem. 274:33609-33615.

39. Wang, K., and S. Ohnuma. 1999. Chain-length determination mechanism of isoprenyl diphosphate synthases and implications for molecular evolution. Trends Biochem. Sci. 24:445-451.

40. WHO. 2008. World malaria report, vol. WHO/HTM/GMP/2008.1. World Health Organization, Geneva, Switzerland.

41. Wiesner, J., and H. Jomaa. 2007. Isoprenoid biosynthesis of the apicoplast as drug target. Curr. Drug Targets 8:3-13.

42. Yardley, V., et al. 2002. In vivo activities of farnesyl pyrophosphate synthase inhibitors against Leishmania donovani and Toxoplasma gondii. Antimicrob. Agents Chemother. 46:929-931.

43. Yoh, K., S. Takata, N. Yoshimura, and J. Hashimoto. 2010. Efficacy, tolerability, and safety of risedronate in Japanese patients with Paget's disease of bone. J. Bone Miner. Metab. 28:468-476.

44. Yokoyama, K., et al. 1998. The effects of protein farnesyltransferase inhibitors on trypanosomatids: inhibition of protein farnesylation and cell growth Mol. Biochem. Parasitol. 94:87-97. 
APÊNDICE B - Cloning and characterization of bifunctional enzyme farnesyl diphosphate synthase/geranilgeranyl diphosphate synthase of Plasmodium falciparum. (manuscrito submetido) 
Cloning and characterization of bifunctional enzyme farnesyl diphosphate/ geranylgeranyl diphosphate synthase of Plasmodium falciparum

Fabiana M. Jordão ${ }^{1}$, Heloisa B. Gabriel ${ }^{1}$, Claudia B. Angeli ${ }^{1}$, Thaís D. Bifano ${ }^{1}$, Ardala Breda $^{3}$, Mauro F. de Azevedo ${ }^{2}$, Luiz A. Basso ${ }^{3}$, Gerhard Wunderlich ${ }^{1}$, Emilia A. Kimura $^{1}$, Alejandro M. Katzin ${ }^{1}$

${ }^{1}$ From the Department of Parasitology, Institute of Biomedical Sciences, University of São Paulo, São Paulo, Brazil.

${ }^{2}$ The Macfarlane Burnet Institute for Medical Research and Public Health, Melbourne, Victoria, Australia.

${ }^{3}$ Research Center for Molecular Biology and Functional, National Institute of Science and Technology on Tuberculosis, Pontifical Catholic University of Rio Grande do Sul, Brasil.

Running title: Characterization of $P$. falciparum FPPS/GGPPS.

To whom correspondence should be addressed: Alejandro Miguel Katzin - Department of Parasitology, Institute of Biomedical Sciences, University of São Paulo, Av. Lineu Prestes 1374, CEP 05508-000, São Paulo, SP, Brazil. Telephone: 5511 3091-7330 FAX: 5511 30917417. E-mail: amkatzin@icb.usp.br

Keywords: $P$. falciparum; farnesyl diphosphate; farnesyl diphosphate synthase; geranylgeranyl diphosphate; geranylgeranyl diphosphate synthase.

Background: The enzyme farnesyl diphosphate synthase (FPPS) is a key enzyme of isoprenoid biosynthesis.

Results: Recombinant Plasmodium falciparum FPPS (rPfFPPS) biosynthesizes FPP (farnesyl diphosphate) and GGPP (geranylgeranyl diphosphate).

Conclusion: The rPfFPPS is a bifunctional enzyme on isoprenoid biosynthesis in $P$. falciparum.

Significance: $\quad$ FPPS/geranylgeranyl diphosphate synthase (GGPPS) of $P$. falciparum is a potential drug target, since isoprenoid products are essential for survival of the parasite.

\section{SUMMARY}

Isoprenoids are the most diverse and abundant group of natural products. In Plasmodium falciparum, isoprenoid synthesis proceeds through the methyl erythritol diphosphate pathway and the products are further metabolized by farnesyl diphosphate synthase (FPPS), representing this enzyme into a key branch point of the isoprenoid synthesis. Changes in FPPS activity could alter the flux of isoprenoids compounds down to the various branches of the pathway and, hence, play a central role in the regulation of a number of essential functions of Plasmodium parasites. We show here that recombinant expressed FPPS of $P$. falciparum (rPfFPPS) catalyzes the synthesis of farnesyl diphosphate (FPP), as well as geranylgeranyl diphosphate (GGPP), being therefore a bifunctional FPPS/geranylgeranyl diphosphate synthase (GGPPS) enzyme. The apparent $K_{m}$ values for the substrates dimethylallyl diphosphate (DMAPP), geranyl diphosphate (GPP) and farnesyl diphosphate (FPP) were, respectively, 68 $\pm 5 \mu \mathrm{M}, 8 \pm 1 \mu \mathrm{M}$ and $2.1 \pm 0.4 \mu \mathrm{M}$. Using transgenic parasites with a hemagglutinin-tagged version of FPPS, we show that the protein is expressed constitutively in all intraerythrocytic stages of $P$. falciparum and is localized in the cytosol of the parasite. We also present data demonstrating that the recombinant protein is inhibited by risedronate. Plasmodial FPPS represents 
a potential target for the rational design of chemotherapeutic agents to treat malaria.

Malaria is a leading cause of morbidity and mortality in tropical regions. In 2010, there were an estimated 216 million episodes of malaria of which approximately $81 \%$, or 174 million cases, occurred in the African continent. In a worldwide scale, 655,000 individuals died of malaria, most of them in sub-Saharan Africa (1). Of the five parasites species which infect humans, Plasmodium falciparum is responsible for the vast majority of severe forms and deaths of the disease. Recent observations alert that the parasite is becoming resistant to virtually all drugs currently used in the treatment of the disease. Efforts to tackle this problem are based on combined therapies using drugs to which the parasites have not yet developed resistance, as well as identifying new drug targets (2).

$P$. falciparum parasites harbor an unusual plastid organelle called the apicoplast that has an essential role for their survival since isoprenoid precursors are synthesized there (3). Deletion of this organelle by concomitant supplementation with isoprenoid precursors proved that this is the only essential function of the apicoplast during blood stage growth (4). Isoprenoids are very diverse and constitute an abundantly present group of natural products. Synthesis of isoprenoids is intrinsic to all organisms and lead to vast array of metabolites with diverse functions. Despite their structural and functional variety, all isoprenoids derive from a common precursor, isopentenyl diphosphate (IPP) and its isomer, dimethylallyl diphosphate (DMAPP). Farnesyl diphosphate synthase (FPPS), which belongs to a family of enzymes, classified as prenyltransferases, catalyses the consecutive head-to-tail condensation between IPP with DMAPP, to form geranyl diphosphate (GPP), and then a second condensation between GPP and IPP to form farnesyl diphosphate (FPP). FPP serves as a substrate for the first reaction of several branched pathways leading to the synthesis of compounds such as ubiquinone, dolichol, menaquinone, and prenylated proteins. FPP can also be condensed with an additional
IPP by geranylgeranyl diphosphate synthase (GGPPS) to form geranylgeranyl diphosphate (GGPP) which is also employed in protein prenylation and is related to carotenoid biosynthesis (Fig.1).

The essential and major biosynthetic step in all isoprenoid metabolisms is the elongation of isoprene units by prenyltransferases. These enzymes, which subsequently mediate alkylation of IPP by allylic diphosphate, are classified according to the chain length of the final product and stereochemistry of the double bond formed by condensations. FPPS and GGPPS are the most studied prenyltransferases and have been described in various organisms of all three kingdoms, Eukarya, Bacteria and Archaea (5). In protist parasites, the FPPS gene was cloned from Trypanosoma cruzi (6), Trypanosoma brucei (7) and Toxoplasma gondii (8). Recently a GGPPS from $P$. vivax was described (9). However, the first characterization of prenyltransferase family in malaria parasite was the characterization of the octaprenyl diphosphate synthase (OPPS) that catalyzes the condensation of FPP with IPP to produce octaprenyl diphosphate (OPP) (10).

Human FPPS has been found to be a target for nitrogen-containing bisphosphonates (N-BP) drugs (11). Based on "growth-rescue" and enzyme inhibition experiments, human GGPPS was shown to be a major target for the lipophilic analogs zolendronate and risedronate (12). These reports have generated considerable interest in FPPS as a promising target for new antimalarial drug development. Recently, we suggested the possible mechanism of action for risedronate in $P$. falciparum by inhibition of FPPS (13). In the causative agent of sleeping sickness, T. brucei, the inhibition of FPPS showed that this enzyme is essential for parasite survival (7). Considering that FPPS is a key enzyme of the biosynthesis of compounds already characterized in the parasite, such as dolichols, farnesylated proteins and other final isoprenoids products (14); it is essential to characterize the FPPS from $P$. falciparum in order to establish an appropriate strategy for the development of specific inhibitors. 
In this work, we describe the cloning, expression and characterization of recombinant $P$. falciparum FPPS (rPfFPPS), with catalytic activity for DMAPP, GPP and FPP as substrates, yielding FPP and GGPP as final products. Apparent kinetic parameters for the recombinant enzyme are presented, as well as $\mathrm{IC}_{50}$ and apparent $K_{i}$ values for risedronate inhibition of rPfFPPS enzyme activity. Constitutive protein expression and its subcellular localization are also described.

\section{EXPERIMENTAL PROCEDURES}

$P$. falciparum culture - Cultures of $P$. falciparum clone 3D7 were grown as described (15) replacing human serum for Albumax I $(0.5 \%$, Invitrogen by life technologies) (16). Parasite development and multiplication were monitored by microscopic evaluation of Giemsa-stained thin smears. Schizont stages were purified with magnetic column separation (MACS Separation Columns "CS", Miltenyi Biotec) (17). Column pre-equilibration, washing, and elution were all carried out at room temperature with RPMI-1640 (Sigma Aldrich). For schizont purification, the culture was centrifuged $(2000 \mathrm{X} g$ for 5 $\mathrm{min})$, the pellet ressuspended in RMPI$1640(1: 10 ; \mathrm{v} / \mathrm{v}), 10 \mathrm{ml}$ of the $10 \%$ suspension of erythrocytes were applied to a CS column assembled in a magnetic unit, where only schizonts are retained. After washing the column with $50 \mathrm{ml}$ of RMPI1640 , the column was removed from the magnetic field and its contents eluted with $50 \mathrm{ml}$ of RMPI-1640 and the schizont stage parasites were centrifuged at 2,000 X $g$ for $5 \mathrm{~min}$ at room temperature. The supernatant was discarded, and the pellet of parasites was stored in liquid $\mathrm{N}_{2}$ for subsequent analysis

Isolation and cloning of PF3D7_1128400 gene - A fragment of 1131 bp of the PfFPPS gene (PlasmoDB ID PF3D7_1128400) was amplified using the oligonucleotide primers (Invitrogen by life technologies) PfFPPS1 (5'CCGGATCCATGGAGAACGAGCAGAA TAAC-3') and PfFPPS2 (5'CGGAATTCTCAAGCGCCTGTAAACA AAATGTC-3') using cDNA from mixed stage parasites. After sequencing, the fragment containing the complete ORF was subcloned in pGEX2T for recombinant protein expression using the introduced BamHI and EcoRI sites.

Expression and Purification of rPfFPPS from E. coli - Recombinant pGEX-2TFPPS expression vector was used to transform E. coli BL21(DE3+) pLys RIL cells. Bacterial clones were grown in LB medium containing $50 \mu \mathrm{g} / \mathrm{ml}$ ampicillin and $34 \mu \mathrm{g} / \mathrm{ml}$ chloramphenicol at $37^{\circ} \mathrm{C}$ in Luria Broth (Hi-media) until an $\mathrm{OD}_{600}$ of 0.6. At this time point, the expression of rPfFPPS was induced with $0.2 \mu \mathrm{M}$ isopropyl $\beta$-Dthiogalactoside at $24{ }^{\circ} \mathrm{C}$ overnight. Cells were pelleted by centrifugation and ressuspended in lysis buffer $\mathrm{PBS} / 0.1 \%$ Triton X-100 pH 7.2 (v/v), $0.05 \mathrm{mg} / \mathrm{ml}$ lysozyme and $0.2 \mathrm{mM}$ PMSF. Lysis was completed by sonication (five pulses of $30 \mathrm{~s}$ at $40 \mathrm{~W}$, at $4{ }^{\circ} \mathrm{C}$ ). Recombinant proteins were then purified using Glutathione Sepharose beads (GE Healthcare), following the manufacturer's instructions. Proteins were checked for purity by SDSPAGE (18) and quantified by the Bradford method (19).

Enzymatic activity assay - The catalytic activity of rPfFPPS was assayed by measuring the conversion of $\left[4-{ }^{14} \mathrm{C}\right] \mathrm{IPP}$ (56.6 $\mathrm{mCi} / \mathrm{mmol}$, Perkin Elmer Life Sciences) to $\left[{ }^{14} \mathrm{C}\right]$ products, by two different protocols: Protocol I - The method described by Ling et al. (8) was used with some modifications. Briefly, the assay mixtures contained $10 \mathrm{~mm}$ Hepes buffer ( $\mathrm{pH}$ 7.4), $2 \mathrm{mM} \quad \mathrm{MgCl}_{2}, 2 \mathrm{mM}$ dithiothreitol, $100 \mu \mathrm{M}\left[4-{ }^{14} \mathrm{C}\right] \mathrm{IPP}$, an allylic substrate (100 $\mu$ M DMAPP, $30 \mu \mathrm{M}$ GPP, or $15 \mu \mathrm{M}$ FPP), and 500-1000 ng of recombinant protein in a total volume of $100 \mu$ l. The reaction was carried out at 37 ${ }^{\circ} \mathrm{C}$ for $30 \mathrm{~min}$ and stopped by addition of 10 $\mu 1$ of $6 \mathrm{M} \mathrm{HCl}$. The reaction mixture was neutralized by addition of $15 \mu \mathrm{l}$ of $6 \mathrm{M}$ $\mathrm{NaOH}$. The alcoholic products were then extracted twice with $500 \mu \mathrm{l}$ hexane and analysed by reverse phase thin layer chromatography (RP-TLC). All nonradioactive substrates and chemicals were from Sigma - Aldrich. Protocol II rPfFPPS activity was measured by a 
modification of the method described by Chang et al. (20). Final assay concentrations were $50 \mathrm{mM}$ Tris- $\mathrm{HCl}$ buffer $\mathrm{pH} 7.5,2 \mathrm{mM} \mathrm{MgCl}_{2}, 5 \mathrm{mM}$ iodoacetamide, 500-1000 ng of recombinant protein. The concentrations of allylic substrate, DMAPP, GPP and FPP were the same as described above. The final reaction volume was $100 \mu \mathrm{l}$. After preincubation at $37^{\circ} \mathrm{C}$ for $10 \mathrm{~min}$, the reaction was started by adding $50 \mu \mathrm{M}\left[4-^{14} \mathrm{C}\right] \mathrm{IPP}$. The mixture was incubated at $37^{\circ} \mathrm{C}$ for 30 $\min$ and the reaction was terminated by addition of distilled $\mathrm{H}_{2} \mathrm{O}$ and $\mathrm{NaCl}$ saturated water. The diphosphate products were then extracted twice with $500 \mu 1$ of 1butanol saturated with $\mathrm{NaCl}$-saturated water and analyzed by reverse phase highperformance liquid chromatography (RPHPLC). Enzyme activity measurements using $\quad\left[1-(n){ }^{3} \mathrm{H}\right] \mathrm{FPP} \quad(15 \quad \mathrm{Ci} / \mathrm{mmol}$, Amersham, Biosciences) and IPP as substrates were also carried out.

Identification of reaction products of rPfFPPS - The alcoholic products obtained by Protocol I were analysed by TLC on reverse phase Silica Gel 60 plates (Merck) with acetone: $\mathrm{H}_{2} \mathrm{O} \quad(6: 1 ; \mathrm{v} / \mathrm{v})$ (8). The position of the standard prenyl alcohol was visualized using iodine vapour. Radioactivity was visualized by autoradiography in a Storm phosphoimager. The diphosphorylated products that were formed following Protocol II were identified by RP-HPLC and analyzed on a Phenomenex Luna $\mathrm{C}_{18}$ column $(250 \mathrm{~mm} \times$ $4.6 \mathrm{~mm} \times 5 \mu \mathrm{m})$ (Phenomenex) coupled with a $\mathrm{C}_{18}$ pre-column (Phenomenex), a UV Gilson 152/UV variable UV/visible detector at $214 \mathrm{~nm}$ and a FC203B fraction collector. The software used for data processing was the UniPoint LCTM 3.0 Software System. The gradient elution system used was: solvent A, $25 \mathrm{mM}$ $\mathrm{NH}_{4} \mathrm{HCO}_{3}$, pH 8.0; solvent B, $100 \%$ (v/v) acetonitrile. A linear gradient was run from $0 \%$ to $100 \%$ B over a period of $40 \mathrm{~min}$, after which $100 \%$ B was then pumped through for an additional $5 \mathrm{~min}$. Fractions were collected in $1 \mathrm{ml} / \mathrm{min}$ intervals (21). The resulting fractions were dried, ressuspended in $500 \mu \mathrm{l}$ of liquid scintillation mixture (PerkinElmer Life Sciences) and monitored with a Beckman
$5000 \quad \beta$-radiation scintillation counter (Beckman).

ESI-MS/MS investigation of the products geraniol (GOH), farnesol (FOH) and geranylgeraniol $(\mathrm{GGOH})$ - Measurements of product formation by using Protocol I with non-radioactive substrates (IPP/DMAPP) in the presence of rPfFFPS were carried out electrospray ionization tandem mass spectrometry (ESI-MS/MS) using a ion trap mass spectrometer, model $\mathrm{LCQ}^{\mathrm{TM}}$ Duo (Thermo Scientific) coupled to a nano-HPLC system (Ultimate, Dionex). After stopping the reaction, products were extracted with hexane, dried in a vacuum centrifuge, and ressuspended in $40 \mu \mathrm{l}$ of $50 \%$ acetonitrile $/ 0.2 \%$ formic acid. The sample was injected $(10 \mu \mathrm{l})$ in the nanoprobe of the spectrometer by an autosampler (Ultimate, Dionex) at a flow rate of $2 \mu \mathrm{l} / \mathrm{min}$ and analyzed in the positive mode, using the following parameters: spray voltage $1.8 \mathrm{kV}$, capillary voltage $38 \mathrm{~V}$, and capillary temperature $180{ }^{\circ} \mathrm{C}$. For ESIMS/MS, relative collision energy of $30 \%$ $(1.5 \mathrm{eV})$ was applied.

Partial purification of native PfFPPS - The partial purification of native PfFPPS was performed only with schizont stage parasites purified by magnetic column separation, as described above. Partial protein purification was carried out according to Tonhosolo et al (10). Protocol II was used to assay the enzymatic reaction and the diphosphate products were analysed by RP-HPLC, as described above.

rPfFPPS kinetic assays - For determination of apparent kinetic constants, concentration of first substrate DMAPP $(0-150 \mu \mathrm{M})$, GPP $(0-50 \mu \mathrm{M})$ or FPP $(0-50 \mu \mathrm{M})$ were varied in the presence of a fixed concentration of $\left[4-{ }^{14} \mathrm{C}\right] \mathrm{IPP} \quad(50 \mu \mathrm{M})$. Enzyme activity measurements were also carried out varying the concentration of [4${ }^{14} \mathrm{C}$ ]IPP $(0-80 \mu \mathrm{M})$ in the presence of a fixed concentration of either DMAPP (100 $\mu \mathrm{M})$, GPP $(40 \mu \mathrm{M})$ or FPP $(50 \mu \mathrm{M})$. The catalytic activity of rPfFPPS was assayed by measuring the conversion of $\left[4-{ }^{14} \mathrm{C}\right] \mathrm{IPP}$ to $\left[{ }^{14} \mathrm{C}\right]$ products, as described in Protocol I. Reaction products were extracted with hexane and quantified by liquid scintillation 
counting. Apparent kinetic constants, $K_{m}$ and $V_{\max }$, for each substrate were derived from fitting the data to Henri-MichaelisMenten (HMM) Equation (1), using SigmaPlot 10, from Systat Software. All experiments were performed in triplicates.

$v=\frac{V_{\max }[S]}{K_{m}+[S]}$

rPfFPPS inhibition assays - Inhibition assays were performed in presence of a fixed concentration $(30 \mu \mathrm{M})$ of one allylic substrate (GPP or FPP) and fixed concentration $(30 \mu \mathrm{M})$ of $\left[4-{ }^{14} \mathrm{C}\right] \mathrm{IPP}$, with varying concentrations of risedronate $(0.005-1000 \mu \mathrm{M})$. Each assay contained $500 \mathrm{ng}$ of rPfFPPS in a final volume of 100 $\mu$ l. The catalytic activity of rPfFPPS was measured by the conversion of $\left[4-{ }^{14} \mathrm{C}\right] \mathrm{IPP}$ into $\left[{ }^{14} \mathrm{C}\right]$ products, as described in Protocol $I$. The concentration of risedronate required to reduce the fractional enzyme activity to half of its initial value in the absence of inhibitor $\left(\mathrm{IC}_{50}\right)$ was obtained from fitting the data to Equation (2) for partial inhibition $(\mathrm{K})$, in which $y$ is the fractional activity of the enzyme in the presence of inhibitor at concentration [I]; $y_{(\max )}$ is the maximum value of $y$ observed at $[\mathrm{I}]=0$; and $y_{\min }$ is the minimum limiting value of $y$ at high inhibitor concentrations. Data analysis was performed using SigmaPlot 10 (Systat Software). Relationship of $\mathrm{IC}_{50}$ and risedronate apparent dissociation constant $\left(K_{i}\right)$ in each assay was derived according to Cheng and Prusoff relationship, Equation (3), for competitive inhibitors (22), in which $[S]$ and $K_{m}$ are, respectively, the concentration of the substrate for which risedronate is a competitive inhibitor, and this substrate HMM constant. All experiments were performed in triplicates.

$$
\begin{gathered}
y=\frac{y_{\max }-y_{\min }}{1+\frac{[I]}{I C_{50}}}+y_{\min } \\
K_{i}=\frac{I C_{50}}{1+\frac{[S]}{K_{M}}}
\end{gathered}
$$

Plasmid construction - The plasmid pTEX150-HA/Stre3 (23) containing the epitope of hemagglutinin protein (HA) was digested with BglII/PstI to release the gene pTEX150. The genomic DNA sequence encoding the C-terminal fragment of FPPS was PCR amplified with the oligonucleotides 5'AGATCTGGTATGCAAATGGGGGGTA TA and 5'CTGCAGCAGCGCCTGTAAACAAAAT GTC, cloned in the pGEM T-easy vector (Promega) and was verified by sequencing. A recombinant clone was digested with BglII/PstI and ligated into the pTEX150 depleted vector pTEX150-HA/Stre3 generating the plasmid pFPPs-HA.

Parasite transfection and characterization of transfectants - Parasites were transfected as previously described (24), using the electroporation conditions established elsewhere (25). Briefly, P. falciparum 3D7 was cultured in $4 \%$ hematocrit in RPMI HEPES supplemented with $0.5 \%$ Albumax I. $2 \times 10^{7}$ ring stage parasites at 5-8\% parasitemia were transfected with $150 \mu \mathrm{g}$ of plasmid. Transfected parasites were submitted to drug pressure with $2.5 \mathrm{nM}$ WR99210 starting on the third day of culture. Parasites were cultivated in standard conditions until parasites reappeared and normal growth was reestablished. The integration at the genomic FPPS locus was forced by intermittent exposure and retrieval of WR99210. Genomic gDNA was purified using standard protocols. The integration at the genomic locus was checked by PCR under standard conditions using oligonucleotides inside and outside the integrated locus (Fig. S1 for details).

Western Blot analyses - Synchronous cultures of transfected $P$. falciparum were recovered in each stage. Ring, trophozoite or schizont stages were treated with $0.15 \%$ saponin in RPMI media to release hemoglobin from the red blood cells. Proteins were extracted with buffer: $0.05 \mathrm{M}$ Tris-HCl, pH 6.8, $10 \%$ glycerol, $2 \mathrm{mM}$ EDTA, 2\% SDS, $0.05 \%$ bromophenol blue, $50 \mathrm{mM}$ dithiothreitol for separation by gel SDS-PAGE (26). The gel was then transferred to nitrocellulose membrane 
(Amersham) for $1 \mathrm{~h}$ using a Trans-Blot semidry electroblotter (BioRad) (27). After blocking, the membranes were incubated with an $\alpha$-HA monoclonal antibody (1:500 dilution; Sigma - Aldrich) or antibody controls as $\alpha$-PTEX150 (1:1000) (23) or $\alpha$ MSP2 (1:500) (28) for $1 \mathrm{~h}$ at room temperature or $14 \mathrm{~h}$ at $4{ }^{\circ} \mathrm{C}$. After this, the membranes were incubated with a secondary antibody antimouse IgG labeled with peroxidase and were visualized on radiographic film using the ECL enhanced chemiluminescence detection kit according to the instructions of the manufacturer (GE Healthcare).

\section{RESULTS}

Expression and purification of recombinant protein - The $P$. falciparum gene PF3D7_1128400 was formerly annotated as a FPPS and is currently described as a GGPPS according to plasmoDB. Using this sequence as template, primers were designed to amplify $P$. falciparum PF3D7_1128400 gene from total cDNA by PCR. We expressed the full length protein as a GST fusion protein in E. coli BL21(DE3) pLys RIL cells and purified the protein by affinity chromatography as described in Experimental Procedures. The protein homogeneity was inferred by SDSPAGE followed by Coomassie Blue staining, showing that the purified GSTPfFFPS (rPfFPPS) protein has an apparent molecular mass of $\sim 70 \mathrm{kDa}$, (sum of 26 kDa GST and 44 kDa PfFPPS) (Fig. S2).

Catalytic activity of rPfFPPS - To verify if the PF3D7_1128400 gene encodes a functional rPfFPPS protein, its catalytic activity was assessed using the substrate [4${ }^{14} \mathrm{C}$ ]IPP and three different allylic substrates DMAPP, GPP or FPP under the conditions described above. The reaction products were identified by RP-HPLC and TLC.

The products formed following Protocol I were extracted with hexane, and the respective alcohols were submitted to TLC analysis. With the substrates [4${ }^{14} \mathrm{C}$ IIPP and DMAPP, bands with $R_{f}$ corresponding to $\mathrm{GOH}, \mathrm{FOH}$ and $\mathrm{GGOH}$ were observed. Bands with similar $R_{f}$ to FOH and GGOH were detected when [4${ }^{14} \mathrm{C}$ ]IPP and GPP were used as substrates, whereas FPP and $\left[4-{ }^{14} \mathrm{C}\right] \mathrm{IPP}$ yielded only a band with $R_{f}$ coincident with GGOH (Fig. 2 ). When the enzymatic reaction was carried without any enzyme, no products were observed (Fig. 2, lanes 2, 4 and 6). When the enzymatic reaction was carried out with only purified GST, no products were observed (data not shown).

The diphosphorylated products formed following Protocol II were extracted with butanol-satured water and analyzed by RP-HPLC. The rPfFPPS with allylic substrates $\left[4-{ }^{14} \mathrm{C}\right] \mathrm{IPP}$ and DMAPP was able to catalyze the synthesis of GPP, FPP and GGPP (Fig. 3A), whereas the reaction incubated with $\left[4-{ }^{14} \mathrm{C}\right] \mathrm{IPP}$ and GPP as substrates led to the biosynthesis of FPP and GGPP (Fig. 3B). When $\left[4-{ }^{14} \mathrm{C}\right] \mathrm{IPP}$ and FPP were used as substrates, only GGPP synthesis was observed (Fig. 3C). Similar results were obtained when the substrates $\left[1-(n){ }^{3} \mathrm{H}\right] \mathrm{FPP}$ and IPP were incubated with the rPfFPPS (Fig. 3D). When the reaction was carried without enzyme, no products were observed (data not shown). This indicates that major products of the reactions catalyzed by the enzyme rPfFPPS are FPP and GGPP, with a minor production of GPP, with intermediated product. Showing both FPPS and GGPPS activity, detected with usage of using two different enzyme activity protocols.

Identification of rPfFPPs products by $+E S I-$ $M S / M S \dashv$ - Isoprenic compounds were also identified by mass spectrometry. We followed the Protocol I for measurements of enzyme activity with non-radioactive substrates IPP/DMAPP, and investigated the structures of compounds formed in the presence of rPfFPPS by ESI-MS/MS. Fig. 4 shows the results obtained after the enzymatic reaction with non-radioactive substrates IPP/DMAPP. Fig. 4A, C and E present the MS/MS spectra of standards $\mathrm{GOH}, \mathrm{FOH}$ and $\mathrm{GGOH}$ respectively. The fragmentation patterns of the precursor ions at $m / z$ 137, corresponding to dehydration of $\mathrm{GOH}$ (MW 154.25), at $\mathrm{m} / \mathrm{z}$ 205; corresponding to the dehydration of $\mathrm{FOH}$ (MW 222); and at $\mathrm{m} / \mathrm{z} \mathrm{273,} \mathrm{corresponding}$ to the dehydration of GGOH (MW 290), were compared between standards and samples. The dissociation of the precursor ion at $\mathrm{m} / \mathrm{z} 137(\mathrm{GOH})$ revealed the presence of major ions at $\mathrm{m} / \mathrm{z} 81,94$ and 108, while 
the dissociation of the precursor ion at $\mathrm{m} / \mathrm{z}$ $205(\mathrm{FOH})$ resulted in the major ion products at $\mathrm{m} / \mathrm{z} 121,134,148$ and 162 . GGOH precursor ion at $m / z 273$, revealed the product major ions at $\mathrm{m} / \mathrm{z} 149,163,189$ and 217. The molecular identity was confirmed by comparing the ESI-MS/MS spectrum of the ions at $\mathrm{m} / \mathrm{z} 137, \mathrm{~m} / \mathrm{z} 205$ and $m / z 273$ produced by rPfFPPS (Fig. 4B, $\mathrm{D}$ and F) with the ESI-MS/MS spectrum of the standards (Fig. 4A, C and E), revealing the same dissociation profile. These results reinforce the observations in the previous RP-HPLC and TLC experiments by detecting taken together, these results show that the rPfFPPS protein is able to catalyze reactions that lead to formation of $\mathrm{GOH}$, $\mathrm{FOH}$ and GGOH.

Characterization of PfFPPS activity in parasite extracts by HPLC - In order to verify if $P$. falciparum extracts exert similar activities as detected with rPfFPPS, parasite extracts were used instead of recombinant protein. The reaction was performed with $\left[4-{ }^{14} \mathrm{C}\right]$ IPP and DMAPP, GPP or FPP as substrate in accordance with Protocol II. The products were analyzed by RP-HPLC and we detected the formation of products. Incubation of extracts in the presence of [4$\left.{ }^{14} \mathrm{C}\right]$ IPP and DMAPP led to formation of GPP, FPP and GGPP. Likewise, incubation of [4- $\left.{ }^{14} \mathrm{C}\right]$ IPP and GPP as substrates yielded FPP and GGPP as products. Finally, only GGPP was observed when extracts were incubated with $\left[4-{ }^{14} \mathrm{C}\right]$ IPP and FPP (Fig. 5). As observed for the purified polypeptide rPfFPPS, both enzyme activities were found when using parasite extracts as the catalyzing entity. In resume, the parasite extracts of parasites exhibited both FPPS and GGPPS activity and these activities were similar to the rPfFPPs protein.

Apparent kinetic parameters of rPfFPPS and risedronate $I C_{50}$ - Apparent kinetic constants of the recombinant enzyme were determined using varied concentrations of $\left[4-{ }^{14} \mathrm{C}\right] \mathrm{IPP}$, DMAPP, GPP, and FPP as substrates (Fig. S3). The parameters were determined as described in Experimental Procedures, by measuring the radioactivity in the hexane fraction. $K_{m}$ and $V_{\max }$ values for each substrate are given in Table 1. Risedronate inhibitory activity against
rPfFFPS, by specifically inhibiting the condensation of IPP with an allylic substrate was assayed as described in Experimental Procedures. Risedronate inhibition was evaluated using FPP/IPP and GPP/IPP as substrates (Fig. S4), yielding, respectively, $\mathrm{IC}_{50}$ values of $1.3 \pm 0.2 \mu \mathrm{M}$ and of $10 \pm 1 \mu \mathrm{M}$. Apparent $K_{i}$ values, assuming risedronate competitive inhibition towards FPP and GPP, are equal to $0.08 \mu \mathrm{M}$ and $1.96 \mu \mathrm{M}$ respectively.

Analysis of rPfFPPS expression during the intra-erythrocytic cycle by Western blot We produced a parasite line that had the FPPS/GGPPS enzyme tagged with the HA epitope, and extracts of these parasites were analyzed for the presence of FPPS-HA. Samples of protein were extracted from parasites synchronized in three main stages (ring, trophozoite and schizont) and detected with the antibody against HA. The results indicate that the enzyme FPPS is constitutively expressed in all stages during the asexual intra-erythrocytic cycle of $P$. falciparum (Fig. 6). As control of the parasite synchronization we used antibodies that recognize pTEX150 (23), a constitutively expressed protein , and MSP2 (28) which is expressed only in schizont stages.

\section{DISCUSSION}

FPPS is a key enzyme in the metabolism of virtually all isoprenoids and it interconnects the 5-carbon moiety isoprenoid synthesis with the mid - or long chained compounds synthesis (Fig. 1). In this study we report the gene PfFPPS as encoding a bifunctional FPPS/GGPPS enzyme and its in vitro inhibition by risedronate.

In many organisms, the prenyltransferases which catalyze chain elongation are highly selective for the chain length of their products. The human genome contains genes for two distinct monofunctional enzymes for FPP and GGPP synthesis $(29,30)$. In the protozoans $T$. cruzi and $P$. vivax, either FPPS or GGPPS is present, respectively $(6,9)$.

rPfFPPS expressed as a GST-fusion protein was used to characterize its functional activity and to determine the apparent kinetic parameters. Interestingly, 
the removal of the GST tag of rPfFPPS resulted in almost complete activity loss (data not shown). An active form of GGPPS from Thermus thermophilus and Sulfolobus acidocaldarius was also overexpressed in E. coli cells as a GST fusion protein. These authors suggested that the presence of GST-tag lead to thermal stability of the recombinant enzymes (31).

Previous studies have shown that many FPPS homologues can accept both DMAPP and GPP as allylic substrates $(32,33)$. When synthesizing FPP from DMAPP, the enzyme catalyzes two condensation reactions with IPP, releasing only trace amounts of the intermediate GPP (34), while GGPPS can accept DMAPP, GPP and FPP as substrates $(35,36)$. The activity of rPfFPPS and the parasite extracts were confirmed by purification of the synthesized products by RP-HPLC. When DMAPP was used as a substrate, GPP was detected in minor amounts while FPP and GGPP were the predominant products. When the reaction was catalyzed with GPP as allylic substrate, the only products observed were FPP and GGPP. Accordingly, when FPP was used as substrate, only GGPP was observed (Fig. $3)$. No products were detected when GGPP was used as a substrate (data not shown). Hence, rPfFPPS is a bifunctional FPPS/GGPPS enzyme. Importantly, similar products were observed using a second approach where alcoholic compounds were analyzed by TLC (Fig. 2). Finally, the structures of products $\mathrm{GOH}, \mathrm{FOH}$ and GGOH were confirmed by ESI-MS/MS (Fig. 4).

The bifunctional property of rPfFPPS in producing GGPP as well as FPP was previously described only in two organisms: the archaebacterium Methanobacterium thermoautotrophicum and $T$. gondii $(8,37)$. A related enzyme was described by Artz et al. in C. parvum. Although this enzyme was annotated as a FPPS, it shows the capacity to produce GGPP and also longer polyisoprenes (up to 35 carbons) with the main products being C25 and C30-compounds with most of the substrates tested (38). This is indicative that the enzymes from $P$. falciparum and $T$. gondii have a rather limited product spectrum compared to the Cryptosporidium homologue.

Amino acids sequence alignment of FPPS from different organisms revealed conserved regions I to VII with two characteristic aspartate rich motifs, one in region II called FARM (first asp-rich motif) and in region VI called SARM (second Asp-rich motif). Ohnuma et al. (39) clearly demonstrated that the product chain lengths of natural FPPS and GGPPS are mainly regulated by the amino acid residues located at the $4^{\text {th }}$ and $5^{\text {th }}$ position upstream of the FARM region. These residues are at the bottom of the active site pocket, making direct interactions with the $\omega$-terminal region of the allylic products. For this reason, the site was designated the CLD (chain length determination) region. Usually three possible amino acid substitutions are described for the $4^{\text {th }}$ and $5^{\text {th }}$ amino acid positions upstream the FARM region, and their identity determine the classification of FPPS and GGPPS: Type I FPPS present aromatic amino acids residues on both positions; Type II and Type III GGPPS present amino acid residues other than aromatic on both positions; Type II FPPS and Type I GGPPS, as well as long chain prenyl synthases, present an aromatic amino acid residue solely at the $5^{\text {th }}$ position. Upon alignment of FPPS/GGPPS from $T$. gondii and GGPPS from $P$. vivax it appears that these proteins share more features with other FPPS as already postulated by Ling et al. (8), and FPPS from P. falciparum also falls in this cluster. However, when one compares the products spectrum of these enzymes, significant differences are encountered: while the bifunctional $T$. gondii enzyme synthesizes similar products compared to $P$. falciparum FPPS/GGPPS, $P$. vivax GGPPS produces exclusively GGPP (9). One may argue that a hydrophilic side chain at the $5^{\text {th }}$ amino acid upstream of the FARM region plays a crucial role for the production of both GGPP and FPP. On the other hand, the methanobacterial version of the enzyme contains a bulky phenylalanine at this position and also produces GGPP and FPP.

This is not the first time that a bifunctional activity is attributed to an enzyme involved in IPP metabolism. The bifunctionality of another prenyltransferase 
has been shown by our group in $P$. falciparum. This enzyme exerts an OPPS activity that catalyzes the condensation reactions of FPP with five molecules of IPP to produce OPP, the isoprenic chain of coenzyme Q (10). Another function of this enzyme is to synthesize phytoene, the first product of the carotene biosynthesis (40).

TLC, HPLC, and ESI-MS/MS results (Fig. 2, 3 and 4) are indicative of bifunctional activity for rPfFPPS, showing catalytic activity with DMAPP, GPP and FPP as first substrates, ultimately yielding GGPP as final product. Based on the conservation among FPPS and GGPPS enzymes, it is tempting to suggest that rPfFPPS mechanism is bi-bi ordered, in which binding of either DMAPP, GPP, or FPP to the free enzyme is followed by IPP binding. However, other sequential or random mechanisms cannot be ruled out for the $P$. falciparum enzyme since the results here presented do not allow the determination of its kinetic mechanism. A mandatory ordered kinetic mechanism has been described for other FPPS, including the human (41), T. cruzi (42), Staphylococcus aureus and E. coli (43) homologues. According to such an ordered mechanism, DMAPP or GPP binds to the free enzyme, with IPP having larger binding affinity for the E:DMAPP or E:GPP binary complexes (41). Farnesyl synthesis by these FPPS homologues is known to proceed through two subsequent steps. The reaction starts with the condensation of one molecule of DMAPP and one molecule of IPP, yielding the first product GPP. A second IPP molecule is condensed with GPP to form FPP final product (44). Accordingly, P. falciparum bifunctional FPPS/GGPPS catalysis is a three-step, four-substrate process (Fig. 1).

Data derived from activity assays of rPfFPPS were apparently hyperbolic to all tested substrate pairs (Fig. S3); suggesting that rPfFPPS follows HMM kinetics. As rPfFPPS catalyzes parallel and consecutive reactions (Fig. 1), the interpretation of the apparent kinetic constants for this complex enzyme system is not trivial (Table 1). The results presented here demonstrate that rPfFPPS is capable of synthesizing GPP, FPP and GGPP from DMAPP and IPP (Fig. 1, steps 1, 2 and 3); FPP and GGPP from
GPP and IPP (Fig. 1, steps 2 and 3); and GGPP from FPP and IPP (Fig. 1, step 3). Assuming that rPfFPPS follows an ordered mechanism for substrate binding, when activity assays where carried out in the presence of DMAPP and IPP, there will be formation of GPP, followed by conversion of GPP to form FPP, which will be competitive inhibitors of the reactions catalysed in steps 1, 2 and 3, since DMAPP, GPP and FPP all compete for binding to the free enzyme active site (Fig. S5). On the other hand, rPfFPPS activity measurements using GPP and IPP as substrates, there will be formation of FPP, which will be competitive inhibitors of the reactions catalysed in steps 2 and 3, since GPP and FPP compete for binding to free enzyme. In this scenario, DMAPP, GPP and FPP will also behave as noncompetitive inhibitors towards the second substrate, IPP (steps 1, 2 and 3). This same issue has being described for human FPPS (41), where the authors clearly point out the difficulties of mechanistic studies modelling and interpretation.

Evaluation of the apparent kinetic constants given in Table 1 should thus be interpreted with caution. Except for the substrate pair FPP/IPP (highlighted in gray), the parameters presented for every other pair of substrates correspond to overall dissociation constants $\left(K_{m}\right)$ and overall $V_{\max }$ values comprising the consecutive and parallel reactions that would be better described by modifications of the HMM equation (Equation 1). Accordingly, the concentration of each alternative substrate and its affinity constants must be added to the equations that would describe each reaction. Equation 4 (45) and Equation 5 (46) would substitute the HMM equation when GPP is used as rPfFPPS substrate for determination of step 2 apparent kinetic constants. For equations 4 and $5, v$ represents the overall reaction rate, $V_{\max }$, is the maximum reaction rate in the absence of an alternative substrate (also considered as an inhibitor), $S$ is the substrate concentration, $I$ is the alternative substrate concentration, $V_{\max }$ app , is the maximum reaction rate in the presence of an alternative substrate, $K_{m}{ }^{\text {app }}$ is the HMM overall dissociation constant in the presence 
of alternative substrates, and $K_{i}^{\text {app }}$ is the apparent dissociation constant for an alternative substrate from EIS complex. The alternative substrate is considered as an inhibitor because its conversion to product will tie up some of the enzyme active sites, which will not be available for substrate binding. Equation 4 is for an ordered bi bi enzyme mechanism (45), whereas equation 5 considers the overall rate as the sum of individual rates when both substrate and inhibitor are present (46). Step 1 reaction (DMAPP as substrate) requires more complex equations, since two alternative substrates will be present (GPP and FPP). An alternative kinetic assay that monitor each varied substrate consumption instead of IPP consumption would allow a more precise description of the kinetic constants related to rPfFPPS catalysed reactions (47), by solving Equations 4 and 5 . No hyperbolic deviation was observed in activity assays as Equations 4 and 5 are modifications of HMM Equation 3.

$$
\begin{aligned}
& v=\frac{V_{\max }^{a p p}[S]}{K_{m}^{a p p}\left(1+\frac{[I]}{K_{i}^{a p p}}\right)+[S]} \\
& v=\frac{V_{\max }[S]+V_{\max }^{a p p}[I]}{1+[S]+[I]}
\end{aligned}
$$

Similar $K_{m}$ values for substrate pair IPP/FPP were reported for $H$. sapiens GGPPS $(3 \pm 0.2 \mu \mathrm{M}$ and $4.2 \pm 0.3 \mu \mathrm{M})(29)$ and $P$. vivax GGPPS $(8.4 \pm 1.6 \mu \mathrm{M}$ and 7.3 $\pm 0.7 \mu \mathrm{M})(9)$. The $P$. falciparum substrate pair IPP/FPP also presented similar $K_{m}$ values, of $2.4 \pm 0.3 \mu \mathrm{M}$ and $2.06 \pm 0.4 \mu \mathrm{M}$ (Table 1). The human FPPS enzyme has also been characterized, and $K_{m}$ values for IPP/GPP of $0.6 \pm 0.1 \mu \mathrm{M}$ and $0.7 \pm 0.1 \mu \mathrm{M}$ were reported (41). $P$. falciparum data for substrate pair IPP/GPP indicate similar $K_{m}$ for IPP $(0.81 \pm 0.1 \mu \mathrm{M})$ and almost ten times larger $K_{m}$ value for GPP $(7.8 \pm 1.3$ $\mu \mathrm{M})$. These values, however, correspond to global apparent constants for steps 2 and 3 reactions.

Considering varied substrates DMAPP, GPP and FPP; there appears to be a trend in HMM constant values: $K_{m}(\mathrm{FPP})$ $<K_{m}(\mathrm{GPP})<K_{m}(\mathrm{DMAPP})$ (Table 1).
Increased $K_{m}$ values, without $V_{\max }$ variations, are expected for reactions catalysed in the presence of competitive inhibitors (22), as is the case for these substrates. No such $K_{m}$ variation is expected when IPP is the varied substrate as IPP is a noncompetitive inhibitor with respect to FPP, GPP and DMAPP. Noncompetitive inhibitors are expected to maintain $K_{m}$ values while decreasing $V_{\max }$ values (22). These predictions appear to be borne out by the data presented in Table 1. Nitrogen containing bisphosphonates like risedronate are known to inhibit FPPS enzymes (11). However, when the activity of 26 different bisphosphonates against the GGPPS protein from $P$. vivax was compared to their effect on $P$. falciparum in vitro growth, a poor correlation was found (48). Risedronate is commonly used in the treatment of osteoporosis and it was shown that risedronate has a significant inhibitory effect against murine blood stage malaria (13), also inhibiting $P$. vivax GGPPS (9), and human FPPS (41). We have recently shown that risedronate presents inhibitory activity in in vitro cultures of $P$. falciparum, with $\mathrm{IC}_{50}$ of $20 \pm 1 \mu \mathrm{M}$ We have also shown that risedronate inhibition is reversed by addition of FPP or GGPP to the cultures, but not by the addition of IPP (13).These findings are in agreement with the assumed competitive risedronate inhibition towards FPP and GPP, and noncompetitive inhibition with respect to IPP.

As for the apparent kinetic constants reported in Table 1 , an $\mathrm{IC}_{50}$ value of $10 \pm 1 \mu \mathrm{M}$ for risedronate inhibition in the presence of GPP/IPP substrates also corresponds to a global inhibition value, in which both risedronate and FPP product could account for the inhibitory activity. When risedronate effect was evaluated in the presence of FPP/IPP as substrates, an $\mathrm{IC}_{50}$ value of $1.3 \pm 0.3 \mu \mathrm{M}$ was estimated. The increased $\mathrm{IC}_{50}$ for the rPfFPPS/GGPPS reaction catalyzed with GPP/IPP as substrates is in agreement with the presence of an alternative substrate (FPP) as a competitive inhibitor (22). A similar $\mathrm{IC}_{50}$ value was reported for the inhibition of human FPPS activity by risedronate. When GPP/IPP were used as substrates for FPPS 
enzyme activity measurements, in which there is no alternative substrate present in the reaction mixture, an $\mathrm{IC}_{50}$ value of 2.7 $\mathrm{nM}$ was determined (41). On the other hand, when DMAPP/IPP were the substrates, and reaction product GPP will also inhibit the enzyme along with risedronate, the $\mathrm{IC}_{50}$ value increased to 3.2 $\mathrm{nM}$ (41). The larger $\mathrm{IC}_{50}$ values of risedronate in the presence of alternative substrates can be a consequence of some of the enzyme active sites being occupied by these substrates thereby increasing the concentration of inhibitor to achieve 50\% of enzyme activity inhibition. In addition, in vitro inhibition assays of human FPPS also indicate that risedronate is a time dependent slow tight-binding inhibitor, with lower $\mathrm{IC}_{50}$ values after incubation for 30 minutes of enzyme in the presence of risedronate (41). As described in Experimental Procedures section, rPfFPPS formation of products was evaluated only after 30 minutes incubation time, according to Protocol I. This thus prevents time dependent fluctuation of the $\mathrm{IC}_{50}$ value for the results presented here. Nonetheless, an alternative assay may be necessary to evaluate a possible tight-binding inhibition mechanism for risedronate over rPfFPPS.

With evidence of risedronate being a competitive inhibitor towards GPP and FPP, its apparent $K_{i}$ value was estimated, according to Equation (3), as being equal to $1.96 \mu \mathrm{M}$ (GPP/IPP) and $0.082 \mu \mathrm{M}$ (FPP/IPP). $\quad P$. vivax GGPPS characterization studies reported an apparent $K_{i}$ value of $12.4 \pm 1.7 \mu \mathrm{M}$, when using FPP/IPP as substrates (9); a value 151 times larger than the $K_{i}$ value reported in this work. Even though true $K_{i}$ values must be assigned before a more reliable comparison can be made, P. falciparum FPPS/GGPPS seems to be more prone to risedronate inhibition than its $P$. vivax homologue. Reasoning for this finding is rather elusive at moment.

Gosh et al. have shown that risedronate or zoledronate were not the most potent inhibitors in Plasmodium spp (49). They recently described a new generation of bisphosphonates known as "liphophilic biphosphonates", found to be more active against FPPS/GGPPS both-in vitro and in vivo than any other currently available bisphosphonate (12). In addition, Oldfield et al demonstrated that the lipophilic analogs of risedronate and zolendronate had a stronger inhibitory activity against GGPPS from $P$. vivax and also exhibited antimalarial activity in vitro and in vitro (50). Although risedronate is not a potent drug against $P$. falciparum, we showed by metabolic incorporation with [4${ }^{14} \mathrm{C}$ IPP that risedronate inhibits the biosynthesis of FPP and GGPP and interferes with protein isoprenylation by inhibiting the biosynthesis of FPP and GGPP, while also interferes with the transfer of FPP to parasite proteins (13). These findings are in agreement with the view that risedronate inhibits in vitro $P$. falciparum growth by inhibiting the plasmodial FPPS. Importantly, it is expected that successful inhibition of FPPS - a key enzyme between IPP/DMAPP and all longer polyisoprenoids - exerts a pleiotrophic effect on Plasmodium since it inhibits the function of many important parasite proteins $(10,40)$.

Using parasites transfected with FPPS-HA, we demonstrated that rPfFPPS is expressed constitutively in all stages during intraerythrocytic cycle (Fig. 6). FPP and GGPP are substrates for prenyl:protein transferases (farnesyl transferase and geranylgeranyl transferase), catalyzing the posttranslational modification of proteins (51). Previous studies have demonstrated that posttranslational modification of proteins occurs in all intraerythrocytic stage of $P$. falciparum, suggesting that the enzyme is also active in all stages $(51,52)$.

In conclusion, we demonstrated that rPfFPPS is a bifunctional enzyme, with FPPS/GGPPS activity, producing GPP, FPP and GGPP. Both FPP and GGPP, occupy a central role leading to the synthesis of important classes of compounds. These two compounds were utilized for demonstration the several isoprenoid biosynthesis pathway in P. falciparum (14). Considering that: i) $P$. falciparum does not survive in the absence of the IPP produced in the apicoplast unless this precursor is supplemented (4); ii) the FPPS/GGPPS is the only enzyme responsible for the synthesis of these precursors for the synthesis of larger polyisoprenoids; and iii) that FPPS/GGPPS has major structural 
differences compared to the human FPPS and GGPPS enzymes (29), this enzyme possibly represents an attractive drug target for the development of selective inhibitors aiming the erythrocytic stages of malaria etiologic agent $P$. falciparum. The results presented here and previously published data (13) on risedronate inhibition in vitro and in vivo call for further QSAR experiments for the development of more potent bisphosphonate-based inhibitors.

\section{REFERENCES}

1. WHO. (2011) World Health Organization, Switzerland, 250

2. WHO. (2010a) World Health Organization, Switzerland Second edition, 194

3. Jomaa, H., Wiesner, J., Sanderbrand, S., Altincicek, B., Weidemeyer, C., Hintz, M., Turbachova, I., Eberl, M., Zeidler, J., Lichtenthaler, H. K., Soldati, D., and Beck, E. (1999) Science 285, 1573-1576

4. $\quad$ Yeh, E., and DeRisi, J. L. (2011) PLoS Biol 9, e1001138

5. Wang, K. C., and Ohnuma, S. (2000) Biochim Biophys Acta 1529, 33-48

6. Montalvetti, A., Bailey, B. N., Martin, M. B., Severin, G. W., Oldfield, E., and Docampo, R. (2001) The Journal of biological chemistry 276, 33930-33937

7. Montalvetti, A., Fernandez, A., Sanders, J. M., Ghosh, S., Van Brussel, E., Oldfield, E., and Docampo, R. (2003) J Biol Chem 278, 17075-17083

8. Ling, Y., Li, Z. H., Miranda, K., Oldfield, E., and Moreno, S. N. (2007) The Journal of biological chemistry 282, 30804-30816

9. Artz, J. D., Wernimont, A. K., Dunford, J. E., Schapira, M., Dong, A., Zhao, Y., Lew, J., Russell, R. G., Ebetino, F. H., Oppermann, U., and Hui, R. (2011) The Journal of biological chemistry 286, 3315-3322

10. Tonhosolo, R., D'Alexandri, F. L., Genta, F. A., Wunderlich, G., Gozzo, F. C., Eberlin, M. N., Peres, V. J., Kimura, E. A., and Katzin, A. M. (2005) The Biochemical journal 392, 117-126

11. Kavanagh, K. L., Guo, K., Dunford, J. E., Wu, X., Knapp, S., Ebetino, F. H., Rogers, M. J., Russell, R. G., and Oppermann, U. (2006) Proceedings of the National Academy of Sciences of the United States of America 103, 7829-7834

12. Zhang, Y., Cao, R., Yin, F., Hudock, M. P., Guo, R. T., Krysiak, K., Mukherjee, S., Gao, Y. G., Robinson, H., Song, Y., No, J. H., Bergan, K., Leon, A., Cass, L., Goddard, A., Chang, T. K., Lin, F. Y., Van Beek, E., Papapoulos, S., Wang, A. H., Kubo, T., Ochi, M., Mukkamala, D., and Oldfield, E. (2009) Journal of the American Chemical Society 131, 5153-5162

13. Jordao, F. M., Saito, A. Y., Miguel, D. C., de Jesus Peres, V., Kimura, E. A., and Katzin, A. M. (2011) Antimicrobial agents and chemotherapy 55, 2026-2031

14. Jordao, F. M., Kimura, E. A., and Katzin, A. M. (2011) Memorias do Instituto Oswaldo Cruz 106 Suppl 1, 134-141

15. Trager, W., and Jensen, J. B. (1976) Science 193, 673-675

16. Kimura, E. A., Couto, A. S., Peres, V. J., Casal, O. L., and Katzin, A. M. (1996) The Journal of biological chemistry 271, 14452-14461

17. Trang, D. T., Huy, N. T., Kariu, T., Tajima, K., and Kamei, K. (2004) Malar J 3, 7

18. Laemmli, U. K. (1970) Nature 227, 680-685

19. Bradford, M. M. (1976) Analytical biochemistry 72, 248-254

20. Chang, T. H., Guo, R. T., Ko, T. P., Wang, A. H., and Liang, P. H. (2006) The Journal of biological chemistry 281, 14991-15000

21. Zhang, D., and Poulter, C. D. (1993) Analytical biochemistry 213, 356-361 
22. Copeland, R. A. (2005) Methods of biochemical analysis 46, 1-265

23. de Koning-Ward, T. F., Gilson, P. R., Boddey, J. A., Rug, M., Smith, B. J., Papenfuss, A. T., Sanders, P. R., Lundie, R. J., Maier, A. G., Cowman, A. F., and Crabb, B. S. (2009) Nature 459, 945-949

24. Wu, Y., Sifri, C. D., Lei, H. H., Su, X. Z., and Wellems, T. E. (1995) Proceedings of the National Academy of Sciences of the United States of America 92, 973-977

25. Fidock, D. A., and Wellems, T. E. (1997) Proceedings of the National Academy of Sciences of the United States of America 94, 10931-10936

26. Bullen, H. E., Tonkin, C. J., O'Donnell, R. A., Tham, W. H., Papenfuss, A. T., Gould, S., Cowman, A. F., Crabb, B. S., and Gilson, P. R. (2009) J Biol Chem 284, 25353-25363

27. Hawthorne, P. L., Trenholme, K. R., Skinner-Adams, T. S., Spielmann, T., Fischer, K., Dixon, M. W., Ortega, M. R., Anderson, K. L., Kemp, D. J., and Gardiner, D. L. (2004) Mol Biochem Parasitol 136, 181-189

28. Gerold, P., Schofield, L., Blackman, M. J., Holder, A. A., and Schwarz, R. T. (1996) Mol Biochem Parasitol 75, 131-143

29. Kavanagh, K. L., Dunford, J. E., Bunkoczi, G., Russell, R. G., and Oppermann, U. (2006) The Journal of biological chemistry 281, 22004-22012

30. Ding, V. D., Sheares, B. T., Bergstrom, J. D., Ponpipom, M. M., Perez, L. B., and Poulter, C. D. (1991) The Biochemical journal 275 ( Pt 1), 61-65

31. Ohto, C., Nakane, H., Hemmi, H., Ohnuma, S., Obata, S., and Nishino, T. (1998) Bioscience, biotechnology, and biochemistry 62, 1243-1246

32. Reed, B. C., and Rilling, H. C. (1975) Biochemistry 14, 50-54

33. Reed, B. C., and Rilling, H. C. (1976) Biochemistry 15, 3739-3745

34. Ishii, K., Sagami, H., and Ogura, K. (1986) The Biochemical journal 233, 773777

35. Hefner, J., Ketchum, R. E., and Croteau, R. (1998) Archives of biochemistry and biophysics 360, 62-74

36. Wang, G., and Dixon, R. A. (2009) Proceedings of the National Academy of Sciences of the United States of America 106, 9914-9919

37. Chen, A., and Poulter, C. D. (1993) The Journal of biological chemistry 268, 11002-11007

38. Artz, J. D., Dunford, J. E., Arrowood, M. J., Dong, A., Chruszcz, M., Kavanagh, K. L., Minor, W., Russell, R. G., Ebetino, F. H., Oppermann, U., and Hui, R. (2008) Chemistry \& biology 15, 1296-1306

39. Wang, K., and Ohnuma, S. (1999) Trends in biochemical sciences 24, 445-451

40. Tonhosolo, R., D'Alexandri, F. L., de Rosso, V. V., Gazarini, M. L., Matsumura, M. Y., Peres, V. J., Merino, E. F., Carlton, J. M., Wunderlich, G., Mercadante, A. Z., Kimura, E. A., and Katzin, A. M. (2009) The Journal of biological chemistry 284, 9974-9985

41. Glickman, J. F., and Schmid, A. (2007) Assay and drug development technologies 5, 205-214

42. Sigman, L., Sanchez, V. M., and Turjanski, A. G. (2006) Journal of molecular graphics \& modelling 25, 345-352

43. Sanchez, V. M., Crespo, A., Gutkind, J. S., and Turjanski, A. G. (2006) The journal of physical chemistry. B 110, 18052-18057

44. Ashby, M. N., and Edwards, P. A. (1989) The Journal of biological chemistry 264, 635-640 
45. Segel, H. I. (1963) Enzyme kinetics: Behaviour analysis of rapid equilibrium and steady-state enzyme systems., Wiley-Interscience Publication. John Wiley \& Sons, Inc.

46. Webb, J. L. (1963) Enzyme and metabolic inhibitors, Academic Press.

47. Cook, P. F., and Cleland, W. W. (2007) Enzyme kinetcis and mechanism., Garland Science

48. Mukkamala, D., No, J. H., Cass, L. M., Chang, T. K., and Oldfield, E. (2008) Journal of medicinal chemistry 51, 7827-7833

49. Ghosh, S., Chan, J. M., Lea, C. R., Meints, G. A., Lewis, J. C., Tovian, Z. S., Flessner, R. M., Loftus, T. C., Bruchhaus, I., Kendrick, H., Croft, S. L., Kemp, R. G., Kobayashi, S., Nozaki, T., and Oldfield, E. (2004) Journal of medicinal chemistry 47, 175-187

50. No, J. H., de Macedo Dossin, F., Zhang, Y., Liu, Y. L., Zhu, W., Feng, X., Yoo, J. A., Lee, E., Wang, K., Hui, R., Freitas-Junior, L. H., and Oldfield, E. (2012) Proceedings of the National Academy of Sciences of the United States of America 109, 4058-4063

51. Chakrabarti, D., Da Silva, T., Barger, J., Paquette, S., Patel, H., Patterson, S., and Allen, C. M. (2002) The Journal of biological chemistry 277, 42066-42073

52. Moura, I. C., Wunderlich, G., Uhrig, M. L., Couto, A. S., Peres, V. J., Katzin, A. M., and Kimura, E. A. (2001) Antimicrobial agents and chemotherapy 45, 25532558

Acknowledgments - This work was supported by grants from CNPq and FAPESP (Brazil). F.M.J. is the recipient of a postgraduate fellowship from CNPq. H.B.G. receive postgraduate fellowships from FAPESP. We thank S.Wendel (Sírio Libane's Hospital, NESTA) for providing the erythrocytes. We thank Danilo C. Miguel and Carsten Wrenger for critical reading of the manuscript and Valnice J. Peres for help with parasites preparation.

\section{FOOTNOTES}

*This work was supported by.

1To whom correspondence may be addressed: Department of Parasitology, Institute of Biomedical Sciences, University of São Paulo, Av. Lineu Prestes 1374, CEP 05508-000, São Paulo, SP, Brazil. Telephone: 5511 3091-7330 FAX: 5511 3091-7417. E-mail: amkatzin@icb.usp.br 


\section{FIGURE LEGENDS}

FIGURE 1. Schematic diagram of the isoprenoid synthesis and downstream products in $P$. falciparum. Bisphosphonates are known to inhibit FPPS/GGPPS, thereby preventing the synthesis of FPP and GGPP required for the biosynthesis of ubiquinone, dolichol, carotenoids, menaquinone, tocopherol, and protein prenilation. MEP: methyl erythritol phosphate.

FIGURE 2. Analyses by TLC of products synthesized by rPfFPPS. The activity of rPfFPPS was measured by a ${ }^{14} \mathrm{C}$ radioactivity assay, utilizing $\left[4-{ }^{14} \mathrm{C}\right]$ IPP and DMAPP, GPP, or FPP as allylic substrate. The enzymatic reactions (Protocol I) and TLC were performed as described in the Experimental Procedures section. Lane 1, DMAPP as substrate; lanes 3, GPP as substrate; lane 5, FPP as substrate; lanes 2, 4 and 6 control reactions without enzymes for reactions on lanes 1, 3 and 5. Products labeled with $\left[4-{ }^{14} \mathrm{C}\right] \mathrm{IPP}$ were visualized by a Bioscan System 200 Imaging Scanner. The positions of geraniol $(\mathrm{GOH})$, farnesol $(\mathrm{FOH})$ and geranylgeraniol $(\mathrm{GGOH})$ standards are indicated on the left. The main products detected were FOH and GGOH, indicating that this were the major enzyme products.

FIGURE 3. Analyses by RP-HPLC of products synthesized by rPfFPPS. The enzymatic reactions (Protocol II) and HPLC procedure were performed as described in the Experimental Procedures section. A) $\left[4-{ }^{14} \mathrm{C}\right]$ IPP and DMAPP; B) $\left[4-{ }^{14} \mathrm{C}\right] \mathrm{IPP}$ and GPP; C) $\left[4-{ }^{14} \mathrm{C}\right] \mathrm{IPP}$ and FPP; D) $\left[1-{ }^{3} \mathrm{H}\right] \mathrm{FPP}$ and IPP. Arrows indicate the elution positions of isoprenoid standards. The retention times of GPP, FPP and GGPP were identified by co-injection of commercial standards.

FIGURE 4. Analyses by ESI-MS/MS of the non-radioactive products formed from the rPfFPPS catalyzed reactions, showing the chromatogram and fragmentation spectra of $\mathrm{GOH}, \mathrm{FOH}$ and GGOH standards (A, C, E) and respective fragmentation spectra from sample (B, D, F). The fragment ions of GOH at $\mathrm{m} / \mathrm{z}$ 81, 94 and 108; FOH at $\mathrm{m} / \mathrm{z} 121,134,148$ and 162 and GGOH at $\mathrm{m} / \mathrm{z} 163,189$ and 217 . The molecular identity of the ions was confirmed by comparison of the MS/MS spectrum of the standards and sample.

FIGURE 5. Analyses by RP-HPLC of radiolabeled products synthesized by native PfFPPS of P. falciparum. The reaction of $\left[4-{ }^{14} \mathrm{C}\right] \mathrm{IPP}$ with three allylic substrates: DMAPP, GPP, and FPP were realized. Arrows indicate the elution positions of isoprenoid standards with the retention time of 16, 22 and 25 min respectively. The retention times of GPP, FPP and GGPP were identified by co-injection of commercial standards DMPP (A), GPP (B) and FPP (C).

FIGURE 6. Expression of pFPPs-HA during the intra-erythrocytic cycle of P. falciparum, (R) young trophozoite (T) trophozoite, (S) schizont, $\alpha$-HA antibody against the epitope of hemagglutinin protein (HA) present on plasmid fused to the protein of interest - FPP), controls: $\alpha$-pTEX150 (antibody against pTEX150, protein constitutively expressed during the intraerythrocytic cycle of the parasite), $\alpha$ MSP2 (antibody against MSP2, protein expressed only in the schizont stage). 
TABLE 1. Apparent kinetic constants for rPfFPPS. Concentration ranges for each varied substrate are indicated. Activity versus varied substrate concentration plots are depicted on Supplemental Material - Figure S3.

\begin{tabular}{cccc}
\hline Varied substrate & Fixed substrate & $\boldsymbol{K}_{\boldsymbol{m}}(\boldsymbol{\mu M})$ & $\boldsymbol{V}_{\max }(\mathbf{n m o l} / \mathbf{m i n} / \mathbf{m g})$ \\
\hline DMAPP $(0-150 \mu \mathrm{M})$ & IPP $50 \mu \mathrm{M}$ & $68 \pm 5$ & $452.5 \pm 16$ \\
GPP $(0-50 \mu \mathrm{M})$ & IPP $50 \mu \mathrm{M}$ & $7.8 \pm 1.3$ & $341 \pm 19$ \\
FPP $(0-50 \mu \mathrm{M})$ & IPP 50 $\mu \mathrm{M}$ & $2.06 \pm 0.4$ & $326.5 \pm 16$ \\
IPP $(0-80 \mu \mathrm{M})$ & DMAPP $100 \mu \mathrm{M}$ & $2 \pm 0.3$ & $169 \pm 5.4$ \\
IPP $(0-80 \mu \mathrm{M})$ & GPP $40 \mu \mathrm{M}$ & $0.81 \pm 0.1$ & $224 \pm 3.4$ \\
IPP $(0-50 \mu \mathrm{M})$ & FPP $50 \mu \mathrm{M}$ & $2.4 \pm 0.3$ & $155.6 \pm 4$ \\
\hline
\end{tabular}




\section{FIGURA 1}

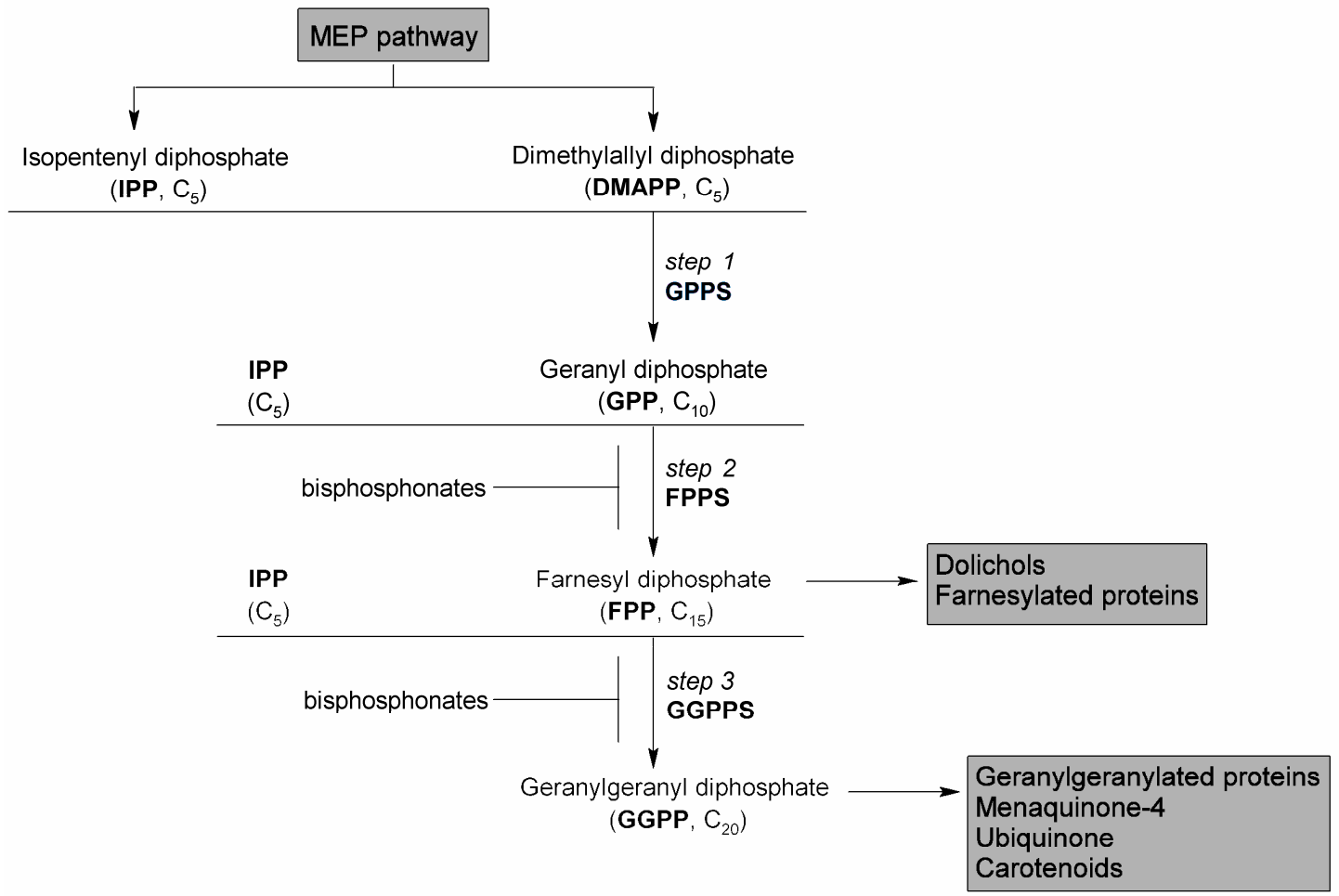


FIGURE 2

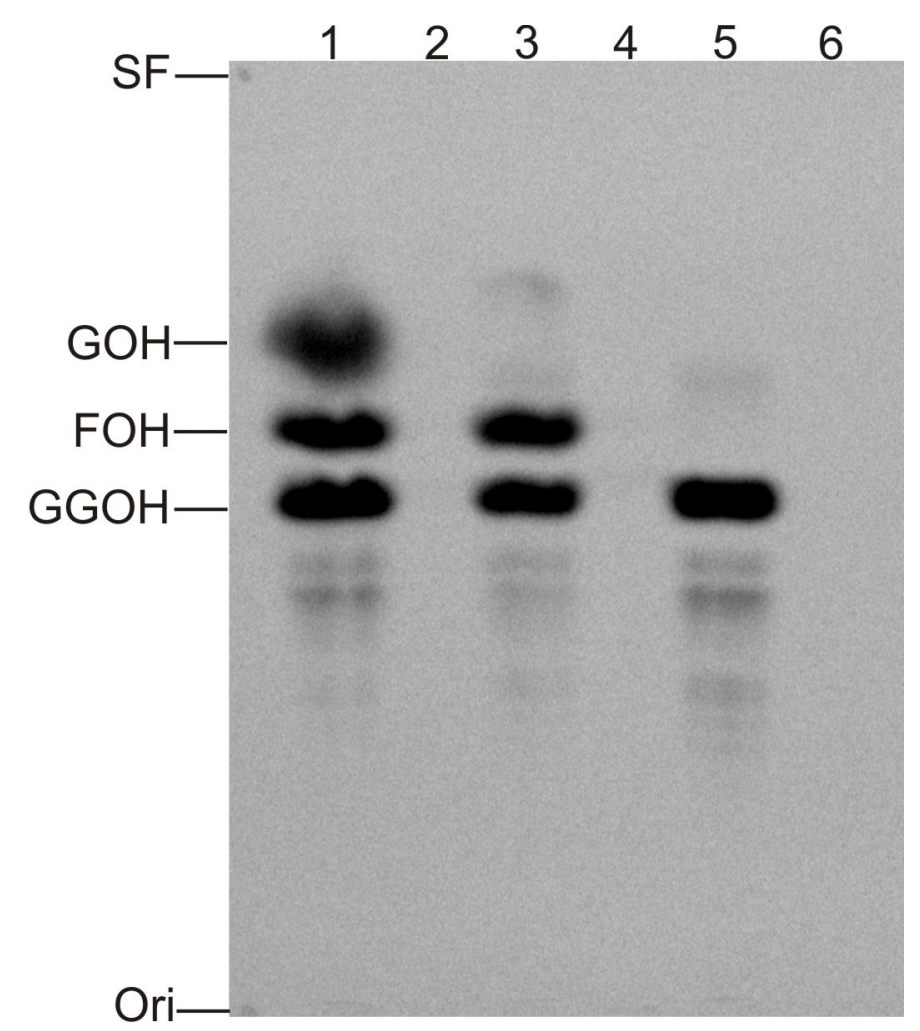


FIGURE 3
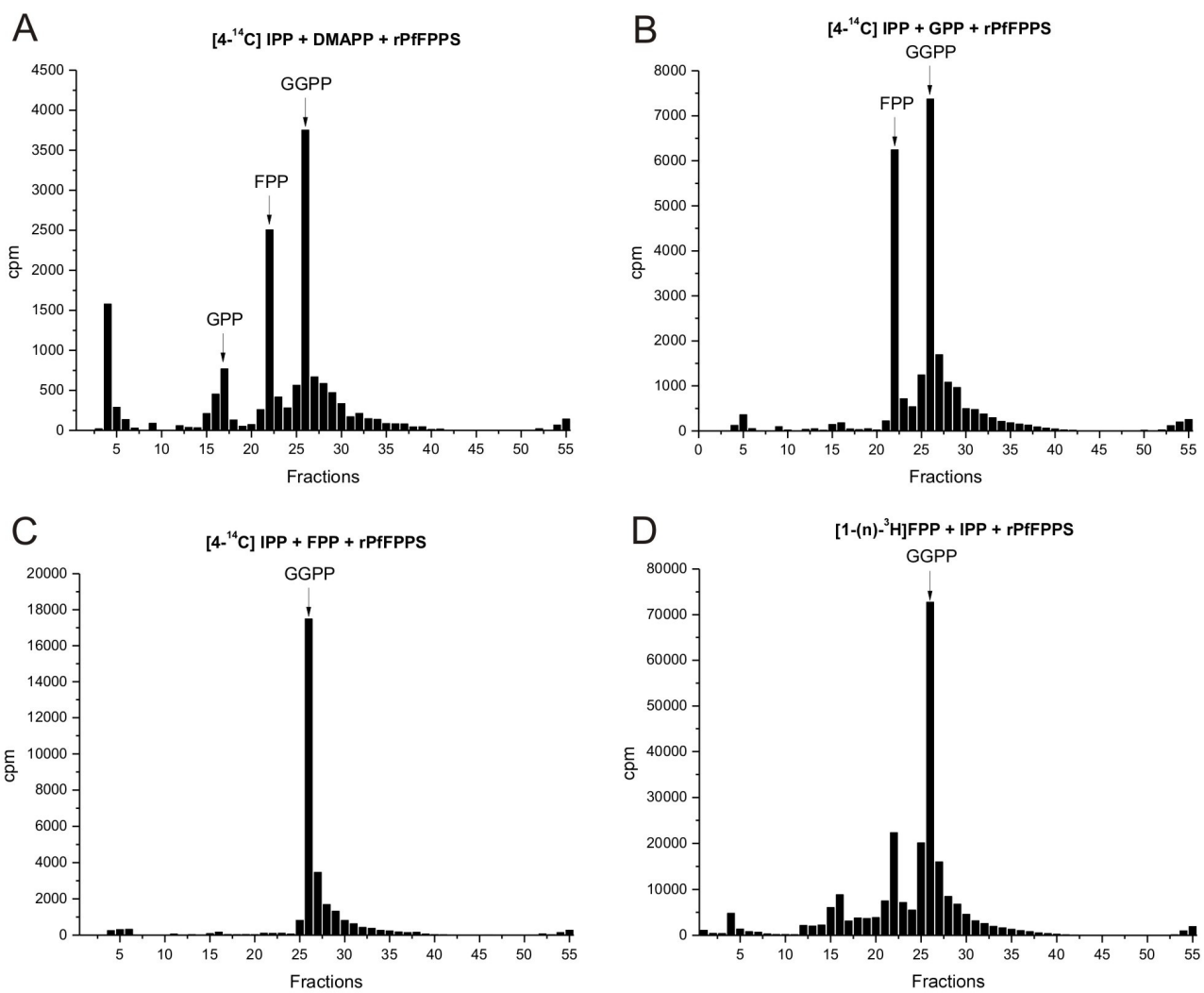


\section{FIGURE 4}
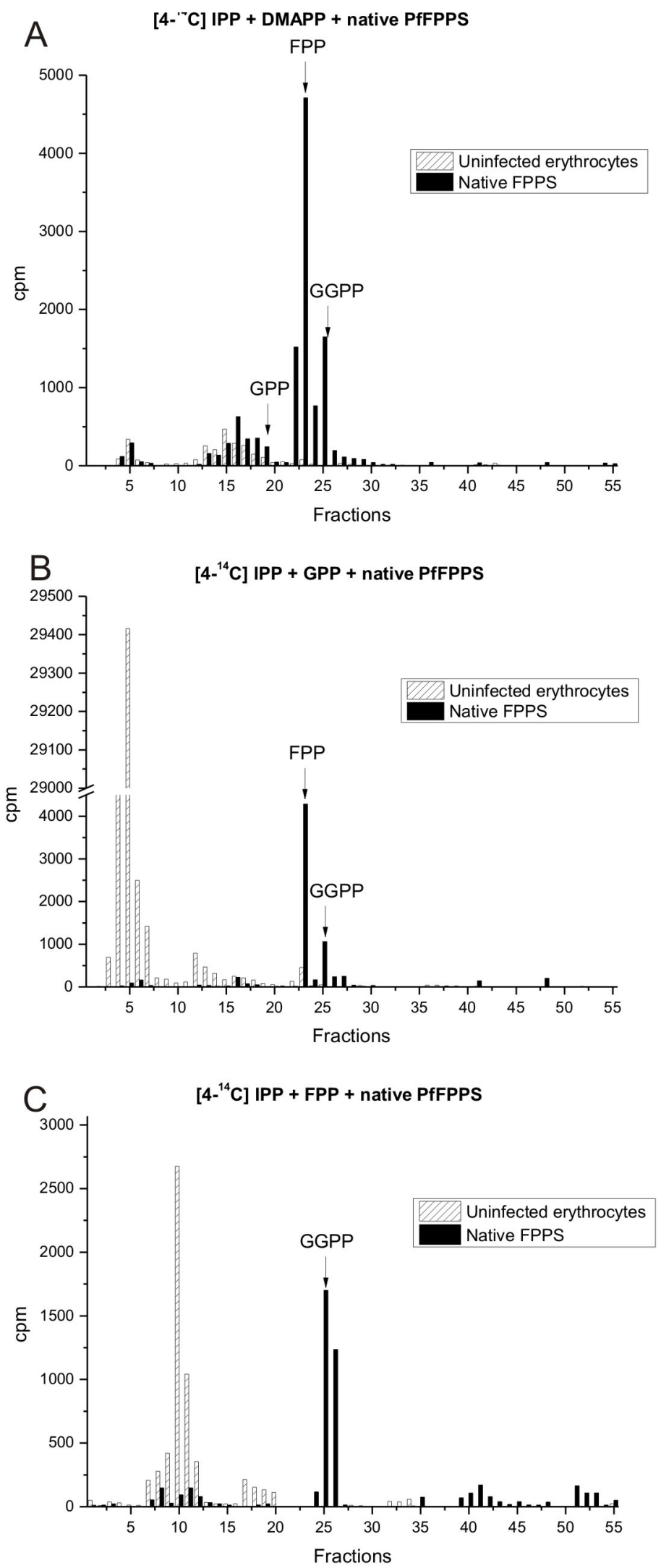
FIGURE 5
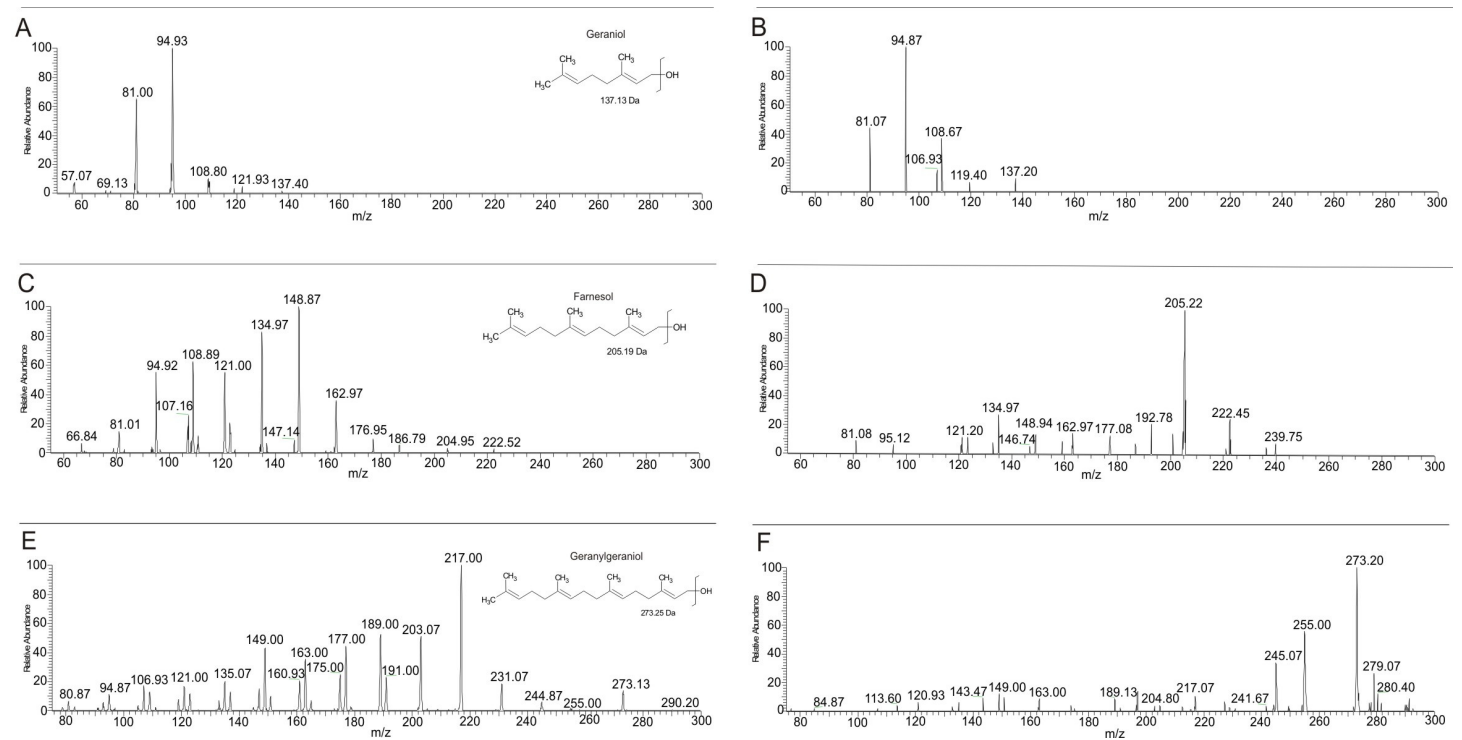
FIGURE 6

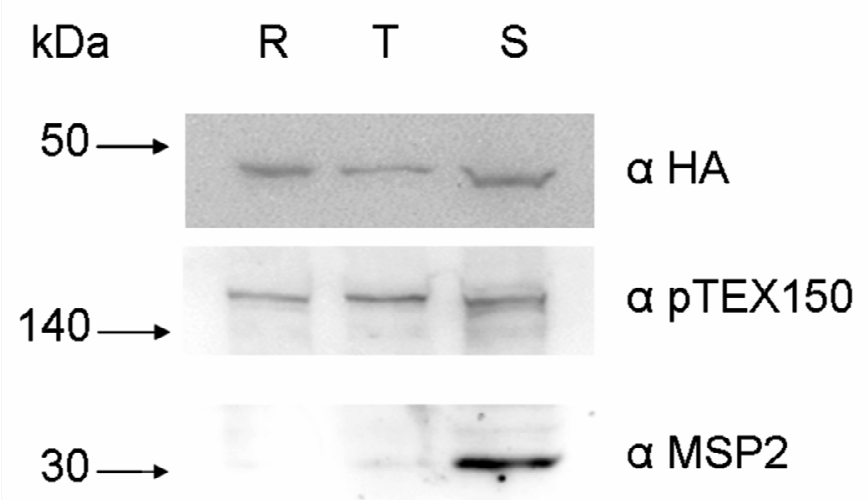




\section{SUPPLEMENTAL MATERIAL}

FIGURE S1. Schematic representation of the integration of rPfFPPs-HA in genomic locus: A: diagram illustrating the integration event by crossing-over and primers designed to detect this event (1,2 and 3). Numbers 1 and 3 indicate the region where the primers have been designed for detecting the integration of the gene in locus. B: PCR detecting the integration of FPP-HA in the genomic locus of P. falciparum using primers 1 and 3. C: Detecting the control PCR amplification of endogenous FPPS gene in both strains (3D7 and transfected) using the primers 1 and 2.

FIGURE S2. Expression of the rPfFPPS. A SDS-polyacrylamide gel $12 \%$ was stained with Coomassie Brilliant Blue. Lane 1, soluble fraction from extract of E. coli BL21(DE3) pLys RIL/rPfFFPS; Lane 2, rPfFPPS fused with GST; lane 3, GST.

FIGURE S3. HMM plots of the steady-state initial velocity experiments for rPfFPPS/GGPPS. Experiments were carried out as described in Experimental Procedures. Concentrations ranges of each varied substrate are depicted on Table 1. Data were fitted to Equation (1).

FIGURE S4. Inhibition of rPfFPPS/GGPPS activity by risedronate. A) Substrate pair FPP/IPP; B) Substrate pair GPP/IPP. rPfFPPS is expressed as its fractional activity; and risedronate concentrations were plotted on log scale. Experiments were carried out as described in Experimental Procedures. Data were fitted to Equation (2).

FIGURE S5. Proposed kinetic mechanism for rPfFPPS. GGPP synthesis is proposed to follow a bi-bi ordered mechanism in an intricate system of parallel and consecutive reactions. 
FIGURE S1

A

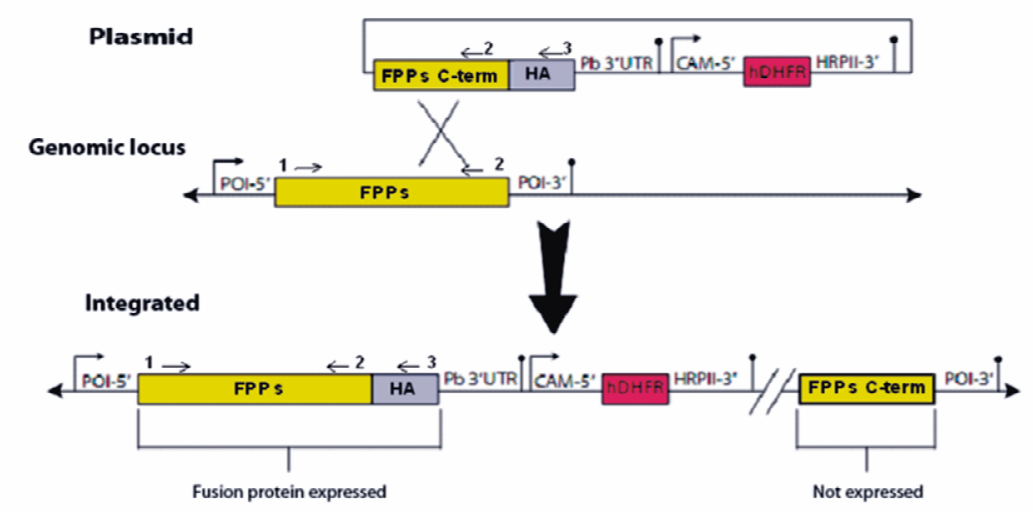

B

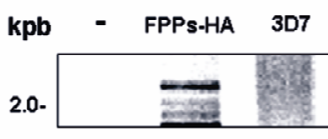

Oligos 1e 3

C

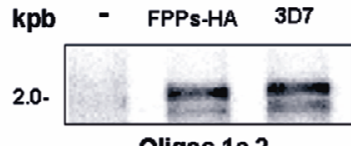

Oligos 1e 2 
FIGURE S2

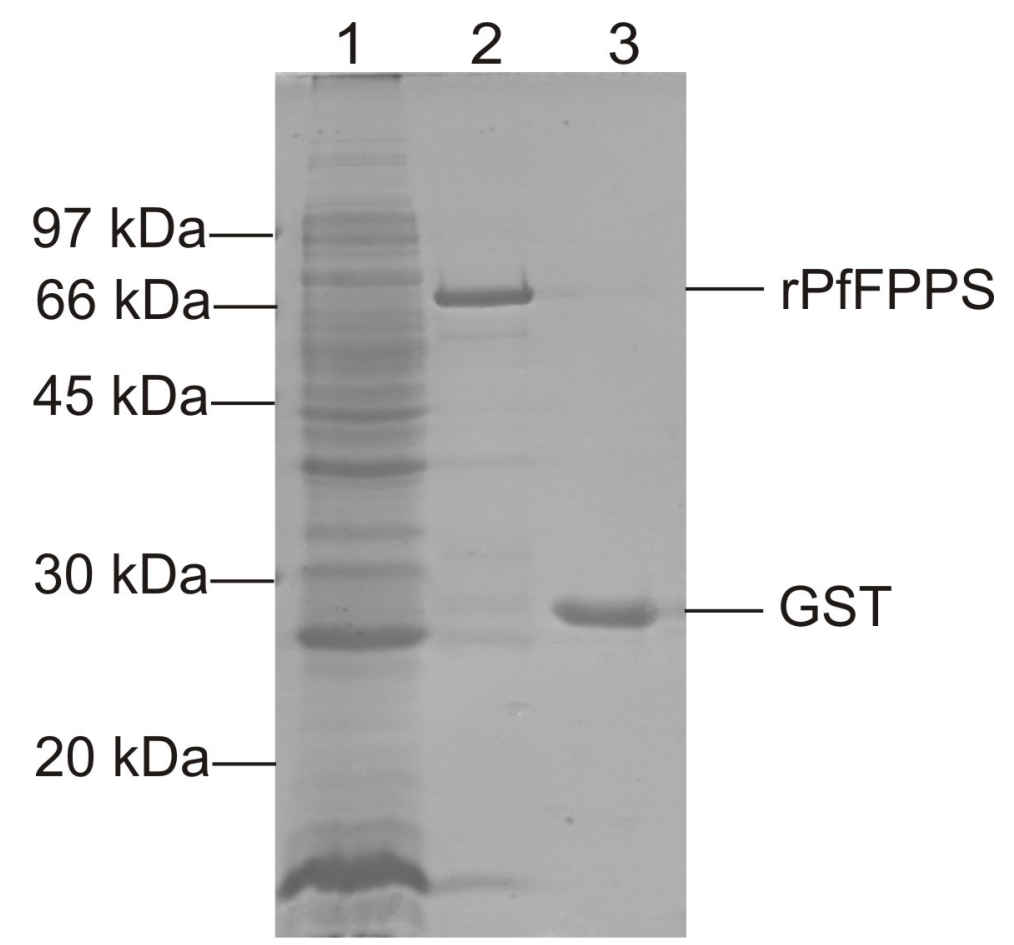


FIGURE S3

A

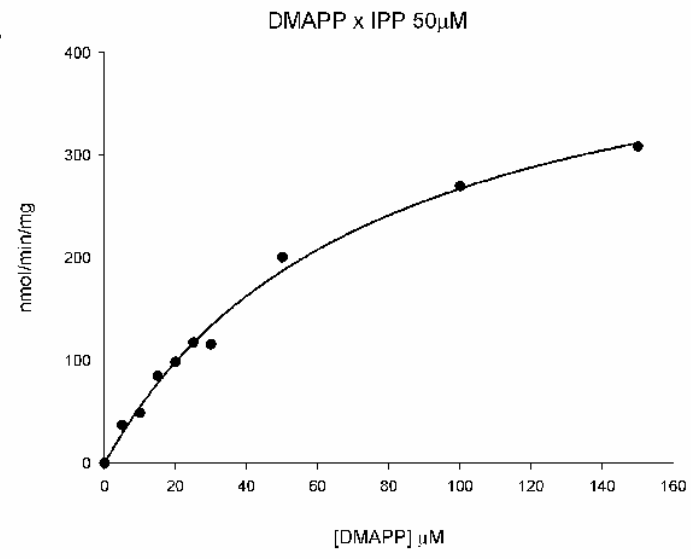

C

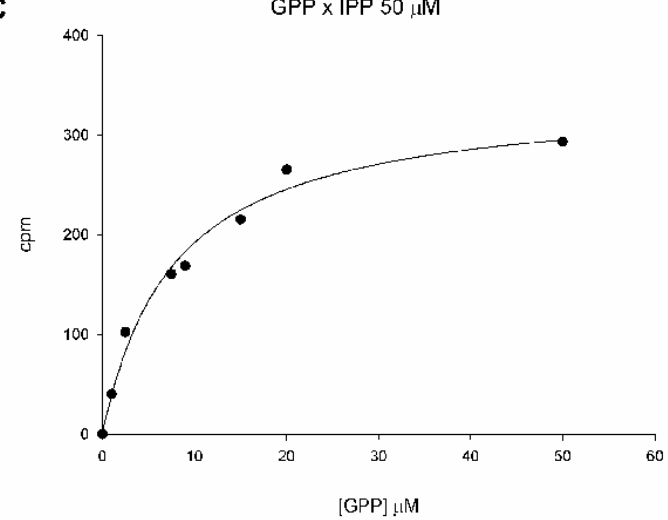

E

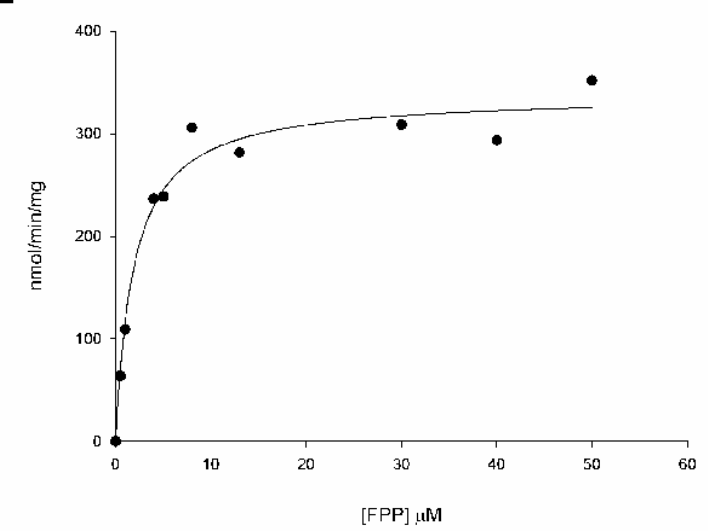

B

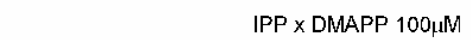

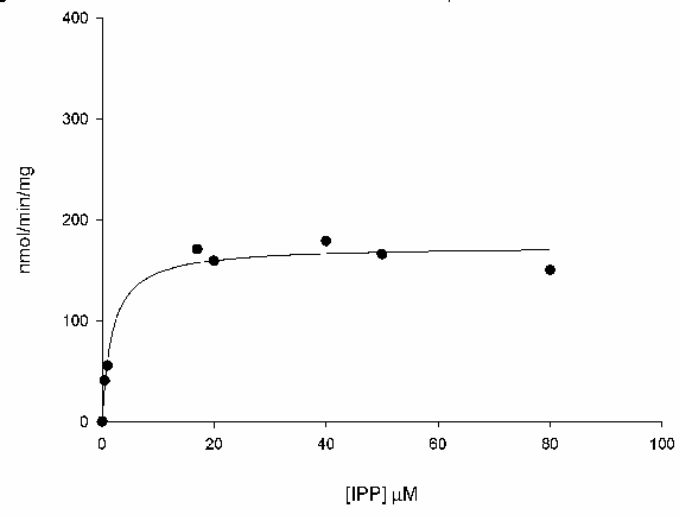

D

400- $\quad$ IPP $\times$ GPP $40, \mu \mathrm{M}$

300

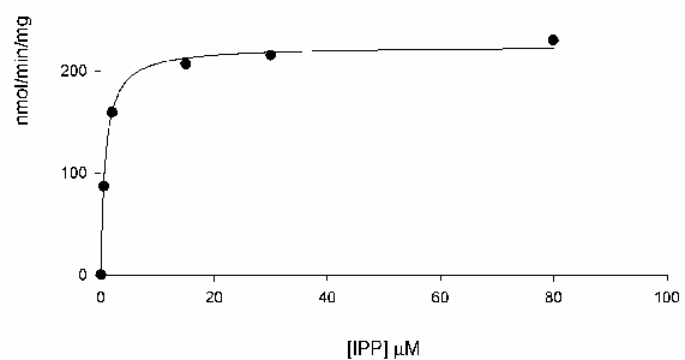

F

IPP $\times$ FPP $50 \mu$,M

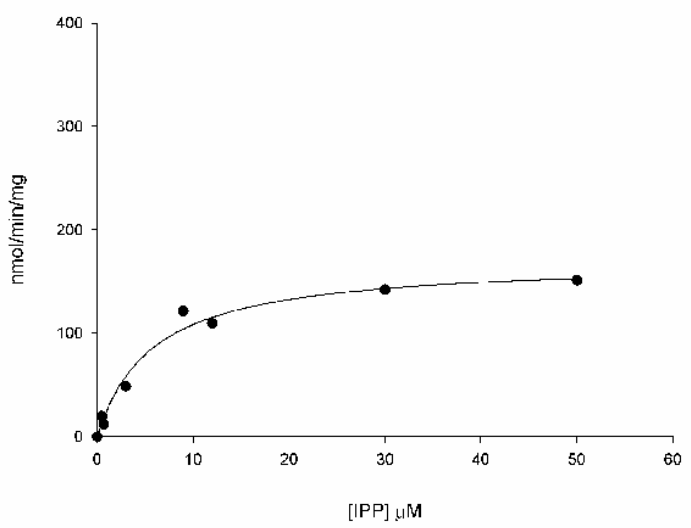




\section{FIGURA S4}

A

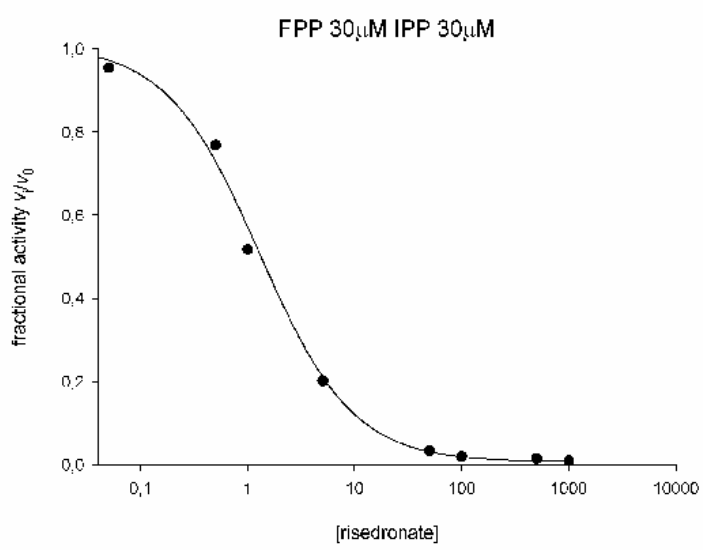

B

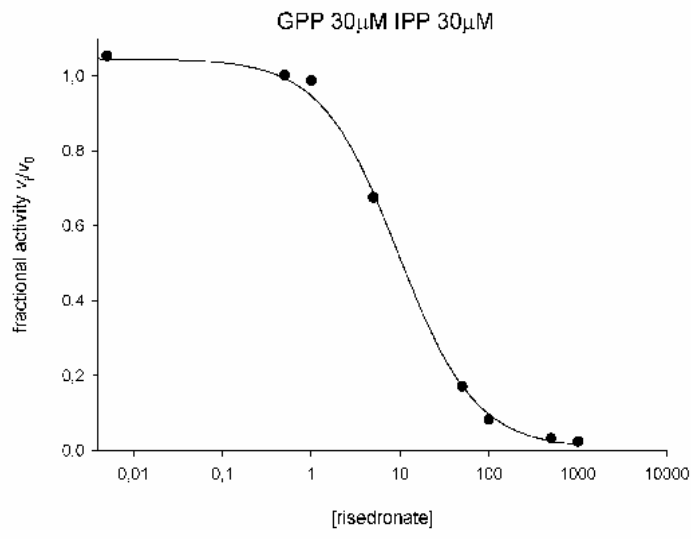




\section{FIGURA S5}

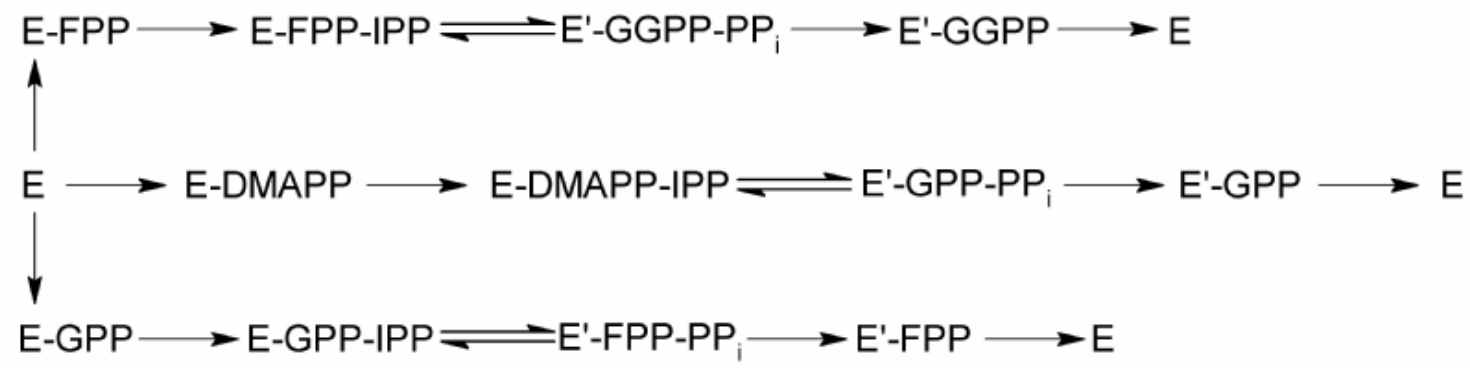


APÊNDICE C - Isoprenoid biosynthesis in the erythrocytic stages of Plasmodium falciparum 


\title{
Isoprenoid biosynthesis in the erythrocytic stages of Plasmodium falciparum
}

\author{
Fabiana Morandi Jordão, Emília Akemi Kimura, Alejandro Miguel Katzin/+ \\ Departamento de Parasitologia, Instituto de Ciências Biomédicas, Universidade de São Paulo, São Paulo, SP, Brasil
}

The development of new drugs is one strategy for malaria control. Biochemical pathways localised in the apicoplast of the parasite, such as the synthesis of isoprenic precursors, are excellent targets because they are different or absent in the human host. Isoprenoids are a large and highly diverse group of natural products with many functions and their synthesis is essential for the parasite's survival. During the last few years, the genes, enzymes, intermediates and mechanisms of this biosynthetic route have been elucidated. In this review, we comment on some aspects of the methylerythritol phosphate pathway and discuss the presence of diverse isoprenic products such as dolichol, ubiquinone, carotenoids, menaquinone and isoprenylated proteins, which are biosynthesised during the intraerythrocytic stages of Plasmodium falciparum.

Key words: malaria - Plasmodium falciparum - isoprenoids - methylerythritol phosphate (MEP) pathway

Malaria is one of the most important tropical parasitic diseases in humans, causing great morbidity and mortality in tropical regions with 300-500 million clinical cases and approximately one million deaths per year (WHO 2010). Human malaria is caused by five species of the Plasmodium parasites, namely Plasmodium falciparum, Plasmodium vivax, Plasmodium ovale, Plasmodium malariae and Plasmodium knowlesi (Cox-Singh \& Singh 2008). P. falciparum is responsible for the vast majority of malaria-related deaths (Snow et al. 2005). The global expansion of the disease has been attributed mainly to the failure of vector control programs, the absence of a vaccine and the increase in parasite resistance to drugs commonly used for therapy. As a result, the discovery and development of new and effective antimalarial agents is imperative. This aim can be achieved in three ways: (i) by focusing on previously validated parasite targets to generate new drug candidates, (ii) by identifying new potential parasite targets for malaria chemotherapy (Ridley 2002) or (iii) by performing highthroughput testing of drug libraries (Guiguemde et al. 2010). With many malaria parasite genome-sequencing projects now complete, efforts are being directed towards a better understanding of gene functions and the discovery of new drug targets (Gardner et al. 2002).

The phylum Apicomplexa harbours a relict plastid known as the apicoplast (McFadden et al. 1996); its discovery brought about an exciting new prospect for drug development against $P$. falciparum (Jomaa et al. 1999, Lim \& McFadden 2010). The apicoplast possesses four

Financial support: CNPq, FAPESP

FMJ is the recipient of a post-graduate fellowship from CNPq.

+ Corresponding author: amkatzin@icb.usp.br

Received 14 April 2011

Accepted 15 June 2011 membranes; therefore, it is hypothesised to be the result of a secondary endosymbiosis, which means that, at some point, the parasite engulfed another eukaryote that contained a plastid obtained by primary endosymbiosis of a cyanobacterium-like prokaryote (Funes et al. 2002, Moore et al. 2008). The apicoplast genome is clearly related to the plastid genome of plants and algae but has a greatly reduced sequence complexity and lacks the genes that encode proteins involved in photosynthesis. Because the structure of the apicoplast was retained in the parasite, it is thought to have an important function for the parasite's survival (Sullivan et al. 2000). A predicted apicoplast proteome has been assembled and putative pathways for the biosynthesis of fatty acids, isoprenoids, iron-sulphur clusters and haem have been mapped to the apicoplast. These metabolic pathways are distinct from the pathways found in the mammalian host, although which of these pathways make the apicoplast indispensable remains to be elucidated (Ralph et al. 2004).

Isoprenoids - With more than 23,000 primary and secondary metabolites, isoprenoids form the most diverse and abundant group of organic compounds in nature. They are derived from branched C5 isoprenoid units. The number of repetitions of this motif, cyclisation reactions, rearrangements and further oxidation of the carbon skeleton are responsible for the enormous structural diversity (Connolly \& Hill 1992). Many types of isoprenoids (steroids, cholesterol, retinoids, carotenoids, ubiquinones and prenyl groups bound to proteins) are essential components of the cellular machinery that are found in all organisms. They participate in a variety of biological processes: (i) carotenoids, chlorophyll and plastoquinone are essential constituents of the photosynthetic apparatus; (ii) ubiquinone, menaquinone (MQ) and plastoquinone are employed as electron carriers required for the mitochondrial respiratory chain; (iii) prenylated proteins, including Ras and Rho GTPases, function as signal transducers; (iv) dolichols participate in the post-translational modification of proteins, an event that is involved in tumour cell 
growth and differentiation and cellular signalling (Wang \& Ohnuma 1999); (v) phosphorylated dolichols have a role as carriers of oligosaccharides in the biosynthesis of glycoproteins and glycosylphosphatidyl inositol anchors (Burda \& Aebi 1999, Spiro 2002).

Isoprenoids vary greatly in size but are all synthesised from a common building block, the isoprene unit isopentenyl diphosphate (IPP) and its isomer dimethylallyl diphosphate (DMAPP). Two distinct and independent pathways exist that biosynthesise IPP: the classical mevalonate pathway and a mevalonate-independent methylerythritol phosphate (MEP) pathway.

The mevalonate pathway - Bloch (1958) and Lynen (1958) first described the mevalonate pathway in animals and yeast revised by Spurgeon and Porter (1981). For several decades, the mevalonate pathway was considered the only biosynthetic route leading to IPP and DMAPP. This pathway uses seven enzymes to supply the precursors in most eukaryotes (all mammals) and in archae bacteria, eubacteria, algae (except chlorophytes), higher plants, bryophytes and some protozoa such as Trypanosoma and Leishmania (Goldstein \& Brown 1990). This pathway starts with a reaction catalysed by a thiolase that produces acetoacetyl-CoA from two molecules of acetyl-CoA. A third acetyl-CoA is then condensed with acetoacetyl-CoA to form 3-hydroxy-3methylglutaryl-CoA (HMG-CoA) by HMG-CoA synthase. The NADPH-dependent HMG-CoA reductase then converts the CoA-bound compound to mevalonic acid (MVA). Next, MVA is sequentially phosphorylated by the mevalonate and diphosphomevalonate kinases to form MVA-5-diphosphate. This diphosphate is subsequently decarboxylated by mevalonate diphosphate decarboxylase to yield a pool of IPP, which is then converted to DMAPP by an IPP isomerase. The enzymes of the mevalonate pathway have been studied from a number of organisms, including humans. HMG-CoA reductase, the best-characterised and rate-limiting enzyme in the pathway, is the target of the statin class of cholesterollowering drugs (Alberts et al. 1980). Whereas the mevalonate pathway in bacteria was previously thought to be due to horizontal gene transfer from other domains, Lombard and Moreira (2011) demonstrated using phylogenetic analyses that the mevalonate pathway is likely ancestral not only in archaea and eukaryotes but also in bacteria. The authors concluded that the mevalonate pathway is likely an ancestral metabolic route in all three domains of life and was probably present in the last common ancestor of all organisms.

The MEP pathway - The MEP pathway was first described in eubacteria (Rohmer et al. 1993) followed by several photosynthetic organisms such as cyanobacteria (Cvejic \& Rohmer 2000), algae (Disch et al. 1998) and higher plants (Rohmer 1999). Later, it was described in apicomplexan parasites (Jomaa et al. 1999) and Mycobacterium tuberculosis (Bailey et al. 2002). It was also found in several pathogenic eubacteria but not in animals or archae bacteria (Lichtenthaler 2000). The initial step, catalysed by 1-deoxy-D-xylulose-5-phosphate (DOXP) synthase, is the formation of DOXP by the condensa- tion of pyruvate and glyceraldehyde-3-phosphate. The $d x p$ gene encoding this enzyme was first cloned from Escherichia coli (Lois et al. 1998). This key enzyme of the pathway requires thiamine diphosphate and divalent cations such as $\mathrm{Mg}^{2+}$ or $\mathrm{Mn}^{2+}$ for its activity. The enzyme DOXP reductoisomerase catalyses the rearrangement and subsequent reduction of DOXP to MEP. The activity of this enzyme is inhibited by fosmidomycin (Kuzuyama et al. 1998). MEP is then converted to 4-(cytidine-5diphospho)-2- $C$-methyl-D-erythritol (CDP-ME) in a cytosine triphosphate-dependent reaction by the isp $D$ gene product CDP-ME synthase. The next step is catalysed by the enzyme CDP-ME kinase and leads to the phosphorylation of CDP-ME. The product of this reaction, 4-(cytidine-5-diphospho)-2- $C$-methyl-D-erythritol-2phosphate (CDP-MEP-2P), is subsequently converted to 2-C-methyl-D-erythritol-2,4-cyclodiphosphate (ME$2,4-\mathrm{cPP}$ ) by the enzyme 2- $C$-methyl-D-erythritol 2,4 cyclodiphosphate synthase. IPP and DMAPP are synthesised through independent routes in the last steps of the MEP pathway (Lichtenthaler 2000). Additionally, the MEP pathway produces the precursor (DOXP) for the synthesis of the essential cofactors thiamine diphosphate and pyridoxal phosphate (Sprenger et al. 1997).

In the following section, we address the recent advances that were made by our group regarding the synthesis of downstream products of the MEP pathway in P. falciparum and the exploitation of these pathways as potential novel drug targets (Figure).

MEP pathway in P. falciparum - Various attempts to provide evidence for the existence of the mevalonate pathway in Plasmodium have led to ambiguous results. To characterise the presence of the mevalonate pathway, $\left[{ }^{3} \mathrm{H}\right]$ mevalonolactone or $(\mathrm{RS})-\left[5-{ }^{3} \mathrm{H}\right]$-mevalonate is commonly used to perform metabolic labelling (Goldstein \& Brown 1990). Unfortunately, all efforts to label isoprenoid constituents with these precursors in P. falciparum were unsuccessful. However, upon incubation of extracts from P. falciparum infected red blood cells with $\left[{ }^{14} \mathrm{C}\right]$ mevalonate, Mbaya et al. (1990) identified farnesyl pyrophosphate. Metabolic labelling of in vitro cultured parasites using $\left[{ }^{3} \mathrm{H}\right]$ mevalonolactone was performed to analyse dolichols and ubiquinones, but no products were identified (AM Katzin et al., unpublished observations). Inhibitors (lovastatin and simvastatin) of HMG-CoA reductase interfered with the in vitro development of $P$. falciparum, but only at high, pharmacologically irrelevant, concentrations (Grellier et al. 1994). Accordingly, no HMG-CoA reductase activity was detectable above background levels in extracts from P. falciparum and $P$. knowlesi (Vial et al. 1984).

Clastre et al. (2007) demonstrated that the MEP pathway was also active in other apicomplexan parasites, namely Eimeria tenella and Toxoplasma gondii. Additionally, transcription profiles confirmed that MEP pathway-related genes were transcribed in these parasites. Intriguingly, BLAST analysis showed that Cryptosporidium parvum and Cryptosporidium hominis lack both the MVA and MEP pathways. However, these species contain orthologs of prenyltransferases, suggesting that isoprenoid precursors perhaps may be acquired from the host. 
In Plasmodium, the apicoplast is the only site of isoprenoid precursor synthesis. Jomaa et al. (1999) demonstrated that a recombinant $P$. falciparum DOXP reductoisomerase, which converts DOXP to MEP, was enzymatically active and could be inhibited by fosmidomycin. The authors also demonstrated that fosmidomycin and its derivative FR900098 are able to inhibit the growth of $P$. falciparum in culture and suppress the in vitro growth of multidrug-resistant $P$. falciparum strains. Moreover, mice infected with the rodent malaria parasite Plasmodium vinckei were cured after treatment with fosmidomycin. However, FR900098 was found to be twice as effective as fosmidomycin. In the same work, the authors showed that an amino-terminal signal sequence in DOXP reductoisomerase targeted the enzyme to the apicoplast. In addition, DOXP reductoisomerase activity could be detected in crude and partially purified protein extracts from $P$. falciparum using a sensitive functional assay (Wiesner et al. 2000).

Recently, it was demonstrated that fosmidomycin directly inhibits its known target, DOXP reductoisomerase, and indirectly acts upon cells to inhibit a second target, the downstream enzyme MEP cytidyltransferase (Zhang et al. 2011). Umeda et al. (2010) obtained crystallised DOXP reductoisomerase from $P$. falciparum and preliminary Xray crystallographic and structural analyses by molecular replacement are in progress. Rohdich et al. (2001) characterised the recombinant enzyme 2-C-methyl-D-erythritol 2,4-cyclodiphosphate synthase in P. falciparum. Finally, Ralph et al. (2004) suggested the presence of several MEP pathway-related genes in $P$. falciparum, all of which possess apicoplast-targeting sequences, indicating that the DOXP pathway is localised in the apicoplast.

Cassera et al. (2004) showed by metabolic labelling with $\left[1-{ }^{14} \mathrm{C}\right]$ acetate, D-[U- $\left.{ }^{14} \mathrm{C}\right]$ glucose and $\left[2-{ }^{14} \mathrm{C}\right] \mathrm{DOXP}$ that the MEP pathway is functionally active in the intraerythrocytic stages of $P$. falciparum. This group identified all but one of the intermediates of the MEP pathway using high-performance liquid chromatography and mass spectrometric analyses. The identified intermediates were DOXP, MEP, CDP-ME, CDP-MEP-2P and ME2,4-cPP (Figure). The effect of fosmidomycin on levels of the MEP pathway intermediates was found to be the most prominent in ring stages and only minor inhibitory effects were observed in the trophozoite and schizont stages, reflecting differences in the drug sensitivity of the parasite blood forms. Cassera et al. (2004) also showed that the MEP pathway provides precursors for the synthesis of ubiquinone and dolichol. This result was demonstrated by the decrease in the ubiquinone and dolichol content in fosmidomycin-treated parasites. Because fosmidomycin inhibits the DOXP reductoisomerase and kills malaria parasites, the biosynthesis of isoprenoids has been presumed to be essential in Plasmodium.

Interestingly, and similar to effects observed for the inhibition of plasmodial dihydrofolate reductase (Zhang \& Rathod 2002), no alteration in the transcription of MEP pathway-related genes was found (Cassera et al. 2007), suggesting that there is no feedback control of transcription exerted by metabolites of the MEP path- way as is often found in other organisms. Surprisingly, fosmidomycin had only a small effect on the growth of either E. tenella or T. gondii in vitro, even at higher concentrations, suggesting that the drug either is not equally active or its uptake varies in different apicomplexan parasites (Clastre et al. 2007).

Thus far, all genes related to the MEP pathway have been identified in the $P$. falciparum genome, but only three genes that encode the enzymes DOXP synthase, DOXP reductoisomerase and 2-C-methyl-D-erythritol2,4-cyclodiphosphate synthase have been functionally characterised. Due to their absence in human cells, enzymes from the MEP pathway are excellent molecular targets for the development of new antimalarial drugs. Field trials in humans have also demonstrated the effectiveness of fosmidomycin in the treatment of human malarial infections (Borrmann et al. 2005, 2006). Recent clinical studies showed that fosmidomycin was effective and well tolerated in the treatment of patients with acute uncomplicated P. falciparum malaria but, unfortunately, resulted in an unacceptably high rate of recrudescence (Wiesner et al. 2002).

Biosynthesis of isoprenoids in P. falciparum - The first reports demonstrating the biosynthesis of isoprenoids in Plasmodium were published by Rietz et al. (1967) and Skelton et al. (1969), showing the occurrence of ubiquinones- 8 and 9 in Plasmodium lophurae and the identification of ubiquinone- 8 biosynthesised by P. knowlesi, Plasmodium cynomolgi, and Plasmodium berghei. Afterwards, Mbaya et al. (1990) showed that schizont extracts of $P$. falciparum biosynthesised isoprenoid until the farnesyl pyrophosphate step upon incubation with $\left[{ }^{14} \mathrm{C}\right]$ mevalonate. Using $\left[{ }^{[4} \mathrm{C}\right]$ acetate, they also demonstrated that the isoprenoid metabolism appeared to be stage-dependent, which was shown by the increase in radiolabelled farnesyl pyrophosphate at the beginning of the schizogonic phase.

Several glycoconjugates, biosynthesised by the intraerythrocytic stages of $P$. falciparum, use dolichol and its phosphorylated derivatives as carrier lipids. Anchors and N-linked glycoproteins require dolichyl phosphate and dolichyl pyrophosphate as carriers of different monosaccharide constituents (Schwarz \& Datema 1982). Kimura et al. (1996) demonstrated the effect of N-linked glycoproteins on differentiation of intraerythrocytic stages of $P$. falciparum. Walter (1986) demonstrated the presence of dolichol kinase, a rate-limiting enzyme for the supply of dolichyl pyrophosphate, in P. falciparum. Many eukaryotic cells, such as yeast and a number of mammalian cells, are unable to incorporate more complex isoprenoid precursors such as $\left[{ }^{3} \mathrm{H}\right] \mathrm{FPP}$ and $\left[{ }^{3} \mathrm{H}\right]$ GGPP. In contrast, intraerythrocytic forms of $P$. falciparum easily metabolise these compounds when they are added to the culture medium, permitting the subsequent identification of higher isoprenoids. Accordingly, Couto et al. (1999) identified dolichol, dolichyl phosphate and dolichyl pyrophosphate of 55 and 60 carbons (11/12 isoprenic units) by metabolic labelling of parasites with $\left[{ }^{3} \mathrm{H}\right] \mathrm{FPP}$ and $\left[{ }^{3} \mathrm{H}\right] \mathrm{GGPP}$ in different intraerythrocytic stages of P. falciparum. This study was the first dem- 
onstration of short-chain dolichols in the phylum Apicomplexa. Despite the fact that few reports exist on the characterisation of dolichols in protozoans, the presence of short-chain isoprenoid species seems to be a common feature. Dolichols of 13 isoprene units in Trypanosoma cruzi (Parodi \& Quesada-Allue 1982), of 11 isoprene units in Crithidia fasciculata (Quesada-Allue \& Parodi 1983) and of 11 and 12 isoprene units in Trypanosoma brucei (Low et al. 1991) have been reported.

The biosynthetic pathways for cholesterol, dolichol and ubiquinones share the same initial steps. Using $\left[1-{ }^{14} \mathrm{C}\right]$ acetate and ${ }^{3} \mathrm{H}_{2} \mathrm{O}$ as labelling precursors, Vial et al. (1984) showed that cholesterol synthesis in P. falciparum was almost undetectable, in accordance with very low levels of measurable HMG-CoA reductase activity.

In $P$. falciparum, the biosynthesis of ubiquinone or coenzyme Q involves two major steps: synthesis of the benzoquinone by the shikimate pathway and synthesis of the isoprene side chain by the MEP pathway. The biosynthesis and regulation of coenzyme Q was also studied in protozoans. T. brucei and Leishmania major synthesise the polyprenyl side of ubiquinone via the mevalonate pathway (Low et al. 1991, Ranganathan \& Mukkada 1995). Coenzyme Q8 and coenzyme Q9 were detected in $P$. falciparum using $\left[{ }^{14} \mathrm{C}\right] \mathrm{PHBA}$ to label the benzoquinone ring in parasite-infected blood from Aotus trivirgatus monkeys (Schnell et al. 1971). de Macedo et al. (2002) demonstrated that P. falciparum has an active isoprenoid pathway for the biosynthesis of the isoprenic chain of coenzyme Q. Additionally, $P$. falciparum is able to synthesise different homologues of this molecule depending on the given intermediate. When labelling was performed with $\left[{ }^{3} \mathrm{H}\right] \mathrm{FPP}$, coenzyme $\mathrm{Q}$ with an isoprenic chain of 40 carbons $\left(\mathrm{Q}_{8}\right)$ was detected, whereas labelling with $\left[{ }^{3} \mathrm{H}\right] \mathrm{GGPP}$ resulted in $\mathrm{Q}_{9}(45$ carbons) moieties. These authors also demonstrated that nerolidol treatment of $P$. falciparum parasites results in a reduced ability to synthesise CoQ and inhibits $P$. falciparum growth in vitro. Rodrigues Goulart et al. (2004) demonstrated that terpenes (farnesol, nerolidol and linalool) exert an inhibitory effect on the biosynthesis of the isoprenic side chain of the benzoquinone ring of

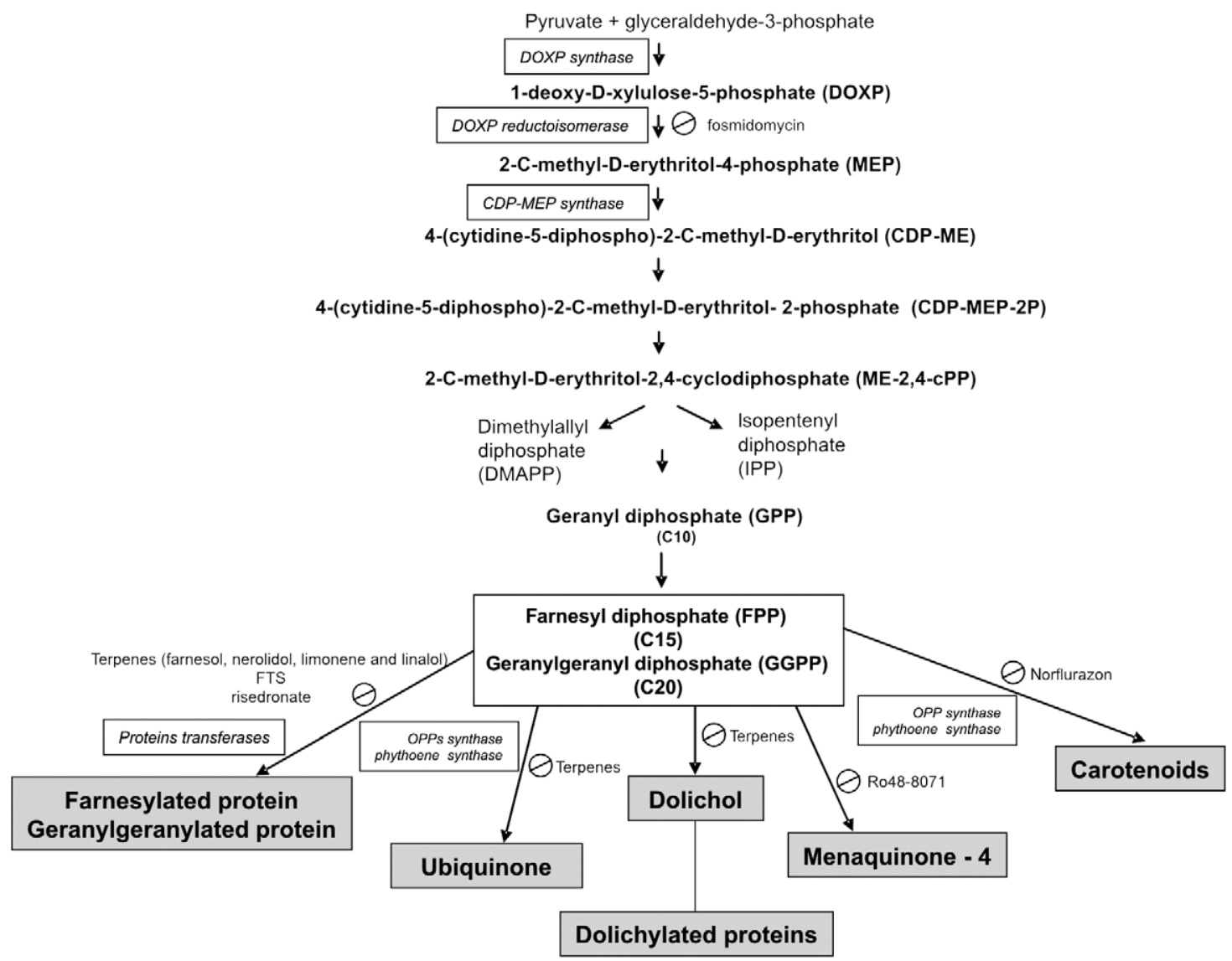

Isoprenoids biosynthesised by Plasmodium falciparum. IPP and DMAPP are biosynthesised by MEP. Steps that are engineered to improve isoprenoid compound production as described in the text are highlighted. The enzymes of this pathway that were characterised in P. falciparum are represented in white boxes and the corresponding inhibitors are in circles. In subsequent steps, IPP and DMAPP are utilised by prenyltransferases to produce a variety of linear allylic prenyl diphosphates of increasing size. GPP C10, FPP C15 and GGPP C20 are intermediates for the synthesis of the wide range of end products derived from the isoprenoid pathway. The shaded boxes indicate the isoprenics compounds currently characterised in P. falciparum by our group. The inhibitor of each isoprenic product is indicated in circles. In the white box, the bi-functional enzyme octaprenyl pyrophosphate synthase (OPPs)/phythoene synthase (PfB0130w) is represented. 
ubiquinones in the schizont stages. Also, these authors showed that all of these terpenes inhibited dolichol biosynthesis in trophozoite and schizont stages when $\left[{ }^{3} \mathrm{H}\right]$ FPP was used as a precursor (Figure).

Octaprenyl pyrophosphate synthase (OPPs) belongs to a prenyl transferase family, which catalyses the condensation reactions of FPP with five molecules of IPP to produce C40 OPP (Guo et al. 2004). OPP enzymes are responsible for the biosynthesis of side chains attached to ubiquinones in E. coli (Okada et al. 1996). Significant differences occur in the length of the isoprenic side chains of ubiquinones from different organisms, suggesting that specific prenyltransferases are involved in the synthesis of these side chains. For example, the sizes of the ubiquinone side chain are C30 in Saccharomyces cerevisiae, C45 in rats and C50 in humans, and these are synthesized by hexaprenyl pyrophosphate synthase, solanesyl pyrophosphate synthase and decaprenyl pyrophosphate synthase respectively (Ashby \& Edwards 1990, Teclebrhan et al. 1993). In P. falciparum, the isoprenic side chains of ubiquinone contain eight or nine isoprenic units, unlike humans, which contain 10 isoprenic units. These length differences of the isoprenoid side-chain compounds encountered in humans and the malaria parasite $P$. falciparum could possibly be exploited as drug targets (de Macedo et al. 2002).

Tonhosolo et al. (2005) demonstrated the existence of OPPs activity in P. falciparum, and the recombinant protein showed an OPP activity producing polyisoprenoids with eight isoprenic units from FPP and IPP as substrate. The transcription of PfOPPs was found to occur in the ring and trophozoite stages, while the polypeptide was mainly found in the schizont stages. These authors also showed that the recombinant enzyme could be competitively inhibited in the presence of the terpene nerolidol, which has a chemical structure that resembles the substrate FPP. These data suggest that nerolidol inhibits the biosynthesis of dolichol, thereby supporting earlier conclusions from de Macedo et al. (2002). Considering the differences in the length of isoprenic side chains in $P$. falciparum and humans, nerolidol could be exploited as a potential drug in malaria (Figure).

Our group has previously demonstrated that intraerythrocytic stages of $P$. falciparum biosynthesise certain unknown polyisoprenic compounds when $\left[{ }^{3} \mathrm{H}\right] \mathrm{GGPP}$ was used as a metabolic precursor (Couto et al. 1999). Taking into account that plant and algae plastids are sites for polyisoprenoid synthesis including carotenes, we investigated the possibility that $P$. falciparum was also able to produce carotenoids because carotenoids have GGPP as a precursor in other organisms.

The chemical characteristics and physical properties of carotenoids are responsible for their abilities to absorb light, scavenge free radicals and act as antioxidants, which are essential during photosynthesis. Tonhosolo et al. (2009) showed for the first time that the biosynthesis of carotenoids is functionally active in the intraerythrocytic stages of $P$. falciparum, representing another "plant-like" pathway present in these parasites. In this work, we detected that the full-length version of the previously de- scribed PfOPPs also exerted phytoene synthase activity. Accordingly, norflurazon, a well-known bleaching herbicide that inhibits carotenoid biosynthesis in higher plants and microalgae, inhibited in vitro growth of $P$. falciparum. This inhibition could be partially reversed by the addition of lycopene, a downstream product in the carotenoid pathway. The function of carotenoid in the malaria parasite is unknown. However, in T. gondii, Nagamune et al. (2008) demonstrated the biosynthesis of phytohormone abscisic acid, a final product of the biosynthesis of carotenoid, which controls calcium signalling within the apicomplexan parasite. Because carotenoid biosynthesis is absent in humans, this pathway might also be exploited as a new target for antimalarial drugs.

Vitamins are essential components of the human diet. By contrast, the malaria parasite P. falciparum and related apicomplexan parasites synthesise certain vitamins de novo, either completely or in part, highlighting the parasite's distinct requirements for nutrients and growth factors. Furthermore, the lack of these pathways in the mammalian host implies that inhibition of the parasite pathways might be exploitable for the design of new antimalarials. The MEP and shikimate pathways supply the precursors for biosynthesis of vitamin K2 or MQ in bacteria and phylloquinone in plants, algae and cyanobacteria. In P. falciparum, Tonhosolo et al. (2010) showed that the intraerythrocytic stages have an active pathway for the biosynthesis of MQ-4 and demonstrated that MQ could replace the physiological function of ubiquinone under anaerobic conditions. Many respiratory enzymes from $E$. coli can use MQ and ubiquinone as substrates depending on the oxygen supply in the environment, whereas mammals have only ubiquinone. $P$. falciparum can be regarded as microaerophilic during its asexual intraerythrocytic life cycle. Tonhosolo et al. (2010) showed that $P$. falciparum can change the content of the quinone pools depending on the aeration condition. Additionally, they showed that the mycobacterial inhibitor of MQ synthesis (Ro48-8071) suppressed MQ biosynthesis and parasite growth (Figure).

Post-translational modification of proteins with isoprenoids was first recognised as a general phenomenon in 1984 (Schmidt et al. 1984). The isoprenyl group is bound post-translationally to cysteine residues at the Cterminus of proteins through a thioether bond. Studies have shown that FPP (15 carbons) and GGPP (20 carbons) are the most common isoprenoids attached to proteins. Several of the proteins that undergo these modifications have been identified and many participate in important cell regulatory functions, particularly signal transduction pathways (Zhang \& Casey 1996). Protein prenylation is a general phenomenon in eukaryotic cells and has been described for several protozoan parasites (Lujan et al. 1995, Field et al. 1996, Shen et al. 1996, Ibrahim et al. 2001), including P. falciparum (Chakrabarti et al. 2002).

Families of Rab G-protein and Ras-related proteins have been characterised in P. falciparum (de Castro et al. 1996, Jambou et al. 1996) and Chakrabarti et al. $1998,2002)$ reported the identification of protein farnesyl transferase (PFT) and protein geranylgeranyl 
transferase-I activities in all stages of intraerythrocytic $P$. falciparum. Prenylation might occur in multiple compartments, but none of the P. falciparum prenyl transferases possess apicoplast-targeting signals and prenyl transferase activity has been detected only in cytosolic fractions. Additionally, peptidomimetics and prenyl analogues could inhibit PFT purified from parasites and malaria parasite growth. The presence of isoprenylated proteins has been demonstrated by metabolic labelling in T. gondii (Ibrahim et al. 2001).

Moura et al. (2001) characterised proteins with isoprenic groups by metabolic labelling with $\left[{ }^{3} \mathrm{H}\right] \mathrm{FPP}$ and $\left.{ }^{3} \mathrm{H}\right]$ GGPP. In the same work, treatment of parasites with limonene, an inhibitor of prenyl transferase, inhibited parasite growth by delaying maturation from ring to trophozoite stages and decreased the incorporation of the isoprenic group in proteins.

Later, Rodrigues Goulart et al. (2004) demonstrated that terpenes (farnesol, nerolidol, limonene and linalool) and S-farnesylthiosalicylic acid led to a decrease in the amount of isoprenylated proteins in P. falciparum schizont stages. Recently, Jordão et al. (2011) characterised the antiplasmodial activity of risedronate in vitro and in vivo and demonstrated that risedronate inhibits the transfer of the farnesyl pyrophosphate group to parasite proteins coinciding with parasite growth inhibition in vitro. In vivo treatment with risedronate led to an $88.9 \%$ inhibition of the rodent parasite $P$. berghei in mice on the seventh day of treatment; however, no general increase in survival rates was achieved.

Another type of protein modification is the attachment of a dolichyl group to proteins. This type of modification is characterised by covalently and posttranslationally bound dolichyl groups to the C-terminal cysteine residues of proteins. The protein dolichylation was described in tumour cells and dolichylated proteins are possibly involved in cell cycle control (Hjertman et al. 1997). In P. falciparum, dolichylated proteins with 11 isoprenic units were found attached to 21 and $28 \mathrm{kDa}$ sized proteins. The purpose of dolichylation of proteins in P. falciparum is currently unknown. Because the dolichylated protein species appear predominantly during the replication phase of the parasite (schizogony) (D'Alexandri et al. 2006), one may speculate that its involvement in cell cycle control is similar to that in tumour cells (Hjertman et al. 1997).

Final comments - Despite all of the recent progress in the understanding of the synthesis and the detection of unexpected metabolic intermediates such as phytoene, many questions still remain unanswered. For example, what purpose do carotenes have in the life cycle of Plasmodium? What are proteins modified with isoprenic residues and at which point in the metabolism of Plasmodium do they exert their function? The answers for these questions may reveal not only novel aspects of this evolutionarily special parasite group but also novel points of chemotherapeutic intervention.

\section{ACKNOWLEDGEMENTS}

To Dr Gerhard Wunderlich, for critical reading of manuscript.

\section{REFERENCES}

Alberts, Chen J, Kuron G, Hunt V, Huff J, Hoffman C, Rothrock J, Lopez M, Joshua H, Harris E, Patchett A, Monaghan R, Currie S, Stapley E, Albers-Schonberg G, Hensens O, Hirshfield J, Hoogsteen K, Liesch J, Springer J 1980. Mevinolin: a highly potent competitive inhibitor of hydroxymethylglutaryl-coenzyme A reductase and a cholesterol-lowering agent. Proc Natl Acad Sci USA 77: 3957-3961.

Ashby MN, Edwards PA 1990. Elucidation of the deficiency in two yeast coenzyme Q mutants. Characterization of the structural gene encoding hexaprenyl pyrophosphate synthetase. $J$ Biol Chem 265: 13157-13164.

Bailey AM, Mahapatra S, Brennan PJ, Crick DC 2002. Identification, cloning, purification and enzymatic characterization of Mycobacterium tuberculosis 1-deoxy-D-xylulose 5-phosphate synthase. Glycobiology 12: 813-820.

Block K 1958. On the mechanism of squalene biogenesis from mevalonic acid. Proceedings of the IV International Congress of Biochemistry, Pergamon Press, VIenna, London, p. 20-22.

Borrmann S, Adegnika AA, Moussavou F, Oyakhirome S, Esser G, Matsiegui PB, Ramharter M, Lundgren I, Kombila M, Issifou S, Hutchinson D, Wiesner J, Jomaa H, Kremsner PG 2005. Shortcourse regimens of artesunate-fosmidomycin in treatment of uncomplicated Plasmodium falciparum malaria. Antimicrob Agents Chemother 49: 3749-3754.

Borrmann S, Lundgren I, Oyakhirome S, Impouma B, Matsiegui PB, Adegnika AA, Issifou S, Kun JF, Hutchinson D, Wiesner J, Jomaa H, Kremsner PG 2006. Fosmidomycin plus clindamycin for treatment of pediatric patients aged 1 to 14 years with Plasmodium falciparum malaria. Antimicrob Agents Chemother 50: 2713-2718.

Burda P, Aebi M 1999. The dolichol pathway of N-linked glycosylation. Biochim Biophys Acta 1426: 239-257.

Cassera MB, Gozzo FC, D’Alexandri FL, Merino EF, del Portillo HA, Peres VJ, Almeida IC, Eberlin MN, Wunderlich G, Wiesner J, Jomaa H, Kimura EA, Katzin AM 2004. The methylerythritol phosphate pathway is functionally active in all intraerythrocytic stages of Plasmodium falciparum. J Biol Chem 279: 51749-51759.

Cassera MB, Merino EF, Peres VJ, Kimura EA, Wunderlich G, Katzin AM 2007. Effect of fosmidomycin on metabolic and transcript profiles of the methylerythritol phosphate pathway in Plasmodium falciparum. Mem Inst Oswaldo Cruz 102: 377-383.

Chakrabarti D, Azam T, DelVecchio C, Qiu L, Park YI, Allen CM 1998. Protein prenyl transferase activities of Plasmodium falciparum. Mol Biochem Parasitol 94: 175-184.

Chakrabarti D, Da Silva T, Barger J, Paquette S, Patel H, Patterson S, Allen CM 2002. Protein farnesyltransferase and protein prenylation in Plasmodium falciparum. J Biol Chem 277: 42066-42073.

Clastre M, Goubard A, Prel A, Mincheva Z, Viaud-Massuart MC, Bout D, Rideau M, Velge-Roussel F, Laurent F 2007. The methylerythritol phosphate pathway for isoprenoid biosynthesis in coccidia: presence and sensitivity to fosmidomycin. Exp Parasitol 116: 375-384.

Connolly JD, Hill RA 1992. Dictionary of terpenoids, Chapman \& Hall, New York, 2156 pp.

Couto AS, Kimura EA, Peres VJ, Uhrig ML, Katzin AM 1999. Active isoprenoid pathway in the intra-erythrocytic stages of Plasmodium falciparum: presence of dolichols of 11 and 12 isoprene units. Biochem J 341: 629-637.

Cox-Singh J, Singh B 2008. Knowlesi malaria: newly emergent and of public health importance? Trends Parasitol 24: 406-410.

Cvejic JH, Rohmer M 2000. CO2 as main carbon source for isoprenoid biosynthesis via the mevalonate-independent methylerythritol 4-phosphate route in the marine diatoms Phaeodactylum tricornutum and Nitzschia ovalis. Phytochemistry 53: 21-28. 
D’Alexandri FL, Kimura EA, Peres VJ, Katzin AM 2006. Protein dolichylation in Plasmodium falciparum. FEBS Lett 580: 6343-6348.

de Castro FA, Ward GE, Jambou R, Attal G, Mayau V, Jaureguiberry G, Braun-Breton C, Chakrabarti D, Langsley G 1996. Identification of a family of Rab G-proteins in Plasmodium falciparum and a detailed characterisation of pfrab6. Mol Biochem Parasitol 80: 77-88.

de Macedo CS, Uhrig ML, Kimura EA, Katzin AM 2002. Characterization of the isoprenoid chain of coenzyme Q in Plasmodium falciparum. FEMS Microbiol Lett 207: 13-20.

Disch A, Schwender J, Muller C, Lichtenthaler HK, Rohmer M 1998. Distribution of the mevalonate and glyceraldehyde phosphate/ pyruvate pathways for isoprenoid biosynthesis in unicellular algae and the cyanobacterium Synechocystis PCC 6714. Biochem $J$ 333: $381-388$

Field H, Blench I, Croft S, Field MC 1996. Characterisation of protein isoprenylation in procyclic form Trypanosoma brucei. Mol Biochem Parasitol 82: 67-80.

Funes S, Davidson E, Reyes-Prieto A, Magallon S, Herion P, King MP, Gonzalez-Halphen D 2002. A green algal apicoplast ancestor. Science 298: 2155.

Gardner MJ, Hall N, Fung E, White O, Berriman M, Hyman RW, Carlton JM, Pain A, Nelson KE, Bowman S, Paulsen IT, James K, Eisen JA, Rutherford K, Salzberg SL, Craig A, Kyes S, Chan MS, Nene V, Shallom SJ, Suh B, Peterson J, Angiuoli S, Pertea M, Allen J, Selengut J, Haft D, Mather MW, Vaidya AB, Martin DM, Fairlamb AH, Fraunholz MJ, Roos DS, Ralph SA, McFadden GI, Cummings LM, Subramanian GM, Mungall C, Venter JC, Carucci DJ, Hoffman SL, Newbold C, Davis RW, Fraser CM, Barrell B 2002. Genome sequence of the human malaria parasite Plasmodium falciparum. Nature 419: 498-511.

Goldstein JL, Brown MS 1990. Regulation of the mevalonate pathway. Nature 343: 425-430.

Grellier P, Valentin A, Millerioux V, Schrevel J, Rigomier D 1994. 3-hydroxy-3-methylglutaryl coenzyme A reductase inhibitors lovastatin and simvastatin inhibit in vitro development of Plasmodium falciparum and Babesia divergens in human erythrocytes. Antimicrob Agents Chemother 38: 1144-1148.

Guiguemde WA, Shelat AA, Bouck D, Duffy S, Crowther GJ, Davis PH, Smithson DC, Connelly M, Clark J, Zhu F, Jimenez-Diaz MB, Martinez MS, Wilson EB, Tripathi AK, Gut J, Sharlow ER, Bathurst I, El Mazouni F, Fowble JW, Forquer I, McGinley PL, Castro S, Angulo-Barturen I, Ferrer S, Rosenthal PJ, Derisi JL, Sullivan DJ, Lazo JS, Roos DS, Riscoe MK, Phillips MA, Rathod PK, Van Voorhis WC, Avery VM, Guy RK 2010. Chemical genetics of Plasmodium falciparum. Nature 465: 311-315.

Guo RT, Kuo CJ, Chou CC, Ko TP, Shr HL, Liang PH, Wang AH 2004. Crystal structure of octaprenyl pyrophosphate synthase from hyperthermophilic Thermotoga maritima and mechanism of product chain length determination. J Biol Chem 279: 4903-4912.

Hjertman M, Wejde J, Dricu A, Carlberg M, Griffiths WJ, Sjovall J, Larsson O 1997. Evidence for protein dolichylation. FEBS Lett 416: $235-238$.

Ibrahim M, Azzouz N, Gerold P, Schwarz RT 2001. Identification and characterisation of Toxoplasma gondii protein farnesyltransferase. Int J Parasitol 31: 1489-1497.

Jambou R, Zahraoui A, Olofsson B, Tavitian A, Jaureguiberry G 1996. Small GTP-binding proteins in Plasmodium falciparum. Biol Cell 88: 113-121.

Jomaa H, Wiesner J, Sanderbrand S, Altincicek B, Weidemeyer C, Hintz M, Turbachova I, Eberl M, Zeidler J, Lichtenthaler HK, Soldati D, Beck E 1999. Inhibitors of the nonmevalonate pathway of isoprenoid biosynthesis as antimalarial drugs. Science 285: 1573-1576.
Jordão FM, Saito AY, Miguel DC, Peres VD, Kimura EA, Katzin AM 2011. In vitro and in vivo antiplasmodial activity of risedronate and its interference with protein prenylation in Plasmodium falciparum. Antimicrob Agents Chemother 55: 2026-2031.

Kimura EA, Couto AS, Peres VJ, Casal OL, Katzin AM 1996. N-linked glycoproteins are related to schizogony of the intraerythrocytic stage in Plasmodium falciparum. J Biol Chem 271: 14452-14461.

Kuzuyama T, Shimizu T, Takahashi S, Seto H 1998. Fosmidomycin, a specific inhibitor of 1-deoxy-D-xylulose-5-phosphate reductoisomerase in the nonmevalonate pathway for terpenoid biosynthesis. Tetrahedron Lett 39: 7913-7916.

Lichtenthaler HK 2000. Non-mevalonate isoprenoid biosynthesis: enzymes, genes and inhibitors. Biochem Soc Trans 28: 785-789.

Lim L, McFadden GI 2010. The evolution, metabolism and functions of the apicoplast. Philos Trans R Soc Lond B Biol Sci 365: 749-763.

Lois LM, Campos N, Putra SR, Danielsen K, Rohmer M, Boronat A 1998. Cloning and characterization of a gene from Escherichia coli encoding a transketolase-like enzyme that catalyzes the synthesis of D-1-deoxyxylulose 5-phosphate, a common precursor for isoprenoid, thiamin, and pyridoxol biosynthesis. Proc Natl Acad Sci USA 95: 2105-2110.

Lombard J, Moreira D 2011. Origins and early evolution of the mevalonate pathway of isoprenoid biosynthesis in the three domains of life. Mol Biol Evol 28: 87-99.

Low P, Dallner G, Mayor S, Cohen S, Chait BT, Menon AK 1991. The mevalonate pathway in the bloodstream form of Trypanosoma brucei. Identification of dolichols containing 11 and 12 isoprene residues. J Biol Chem 266: 19250-19257.

Lujan HD, Mowatt MR, Chen GZ, Nash TE 1995. Isoprenylation of proteins in the protozoan Giardia lamblia. Mol Biochem Parasitol 72: 121-127.

Lynen F 1958. Ciba Foundation Symposium o Bio-synthesis of Terpenes and Sterols, GE Wolstenholrne, CM O'Connor (eds.), J and A Churchill, London, 95 pp.

Mbaya B, Rigomier D, Edorh GG, Karst F, Schrevel J 1990. Isoprenoid metabolism in Plasmodium falciparum during the intraerythrocytic phase of malaria. Biochem Biophys Res Commun 173: 849-854.

McFadden GI, Reith ME, Munholland J, Lang-Unnasch N 1996. Plastid in human parasites. Nature 381: 482

Moore RB, Obornik M, Janouskovec J, Chrudimsky T, Vancova M, Green DH, Wright SW, Davies NW, Bolch CJ, Heimann K, Slapeta J, Hoegh-Guldberg O, Logsdon JM, Carter DA 2008. A photosynthetic alveolate closely related to apicomplexan parasites. Nature 451: 959-963.

Moura IC, Wunderlich G, Uhrig ML, Couto AS, Peres VJ, Katzin AM, Kimura EA 2001. Limonene arrests parasite development and inhibits isoprenylation of proteins in Plasmodium falciparum. Antimicrob Agents Chemother 45: 2553-2558.

Nagamune K, Hicks LM, Fux B, Brossier F, Chini EN, Sibley LD 2008. Abscisic acid controls calcium-dependent egress and development in Toxoplasma gondii. Nature 451: 207-210.

Okada K, Suzuki K, Kamiya Y, Zhu X, Fujisaki S, Nishimura Y, Nishino T, Nakagawa T, Kawamukai M, Matsuda H 1996. Polyprenyl diphosphate synthase essentially defines the length of the side chain of ubiquinone. Biochim Biophys Acta 1302: 217-223.

Parodi AJ, Quesada-Allue LA 1982. Protein glycosylation in Trypanosoma cruzi. I. Characterization of dolichol-bound monosaccharides and oligosaccharides synthesized "in vivo". J Biol Chem 257: 7637-7640.

Quesada-Allue LA, Parodi AJ 1983. Novel mannose carrier in the trypanosomatid Crithidia fasciculata behaving as a short alphasaturated polyprenyl phosphate. Biochem J 212: 123-128. 
Ralph SA, van Dooren GG, Waller RF, Crawford MJ, Fraunholz MJ, Foth BJ, Tonkin CJ, Roos DS, McFadden GI 2004. Tropical infectious diseases: metabolic maps and functions of the Plasmodium falciparum apicoplast. Nat Rev Microbiol 2: 203-216.

Ranganathan G, Mukkada AJ 1995. Ubiquinone biosynthesis in Leishmania major promastigotes. Int J Parasitol 25: 279-284.

Ridley RG 2002. Medical need, scientific opportunity and the drive for antimalarial drugs. Nature 415: 686-693.

Rietz PJ, Skelton FS, Folkers K 1967. Occurrence of ubiquinones-8 and -9 in Plasmodium lophurae. Int Z Vitaminforsch 37: 405-411.

Rodrigues Goulart H, Kimura EA, Peres VJ, Couto AS, Aquino Duarte FA, Katzin AM 2004. Terpenes arrest parasite development and inhibit biosynthesis of isoprenoids in Plasmodium falciparum. Antimicrob Agents Chemother 48: 2502-2509.

Rohdich F, Eisenreich W, Wungsintaweekul J, Hecht S, Schuhr CA, Bacher A 2001. Biosynthesis of terpenoids. 2C-methyl-D-erythritol 2,4-cyclodiphosphate synthase (IspF) from Plasmodium falciparum. Eur J Biochem 268: 3190-3197.

Rohmer M 1999. The discovery of a mevalonate-independent pathway for isoprenoid biosynthesis in bacteria, algae and higher plants. Nat Prod Rep 16: 565-574.

Rohmer M, Knani M, Simonin P, Sutter B, Sahm H 1993. Isoprenoid biosynthesis in bacteria: a novel pathway for the early steps leading to isopentenyl diphosphate. Biochem J 295: 517-524.

Schmidt RA, Schneider CJ, Glomset JA 1984. Evidence for posttranslational incorporation of a product of mevalonic acid into Swiss 3T3 cell proteins. J Biol Chem 259: 10175-10180.

Schnell JV, Siddiqui WA, Geiman QM 1971. Biosynthesis of coenzymes $Q$ by malarial parasites. 2. Coenzyme $Q$ synthesis in blood cultures of monkeys infected with malarial parasites (Plasmodium falciparum and P. knowlesi). J Med Chem 14: 1026-1029.

Schwarz RT, Datema R 1982. The lipid pathway of protein glycosylation and its inhibitors: the biological significance of protein-bound carbohydrates. Adv Carbohydr Chem Biochem 40: 287-379.

Shen PS, Sanford JC, Samuelson J 1996. Entamoeba histolytica: isoprenylation of p21ras and p21rap in vitro. Exp Parasitol 82: 65-68.

Skelton FS, Lunan KD, Folkers K, Schnell JV, Siddiqui WA, Geiman QM 1969. Biosynthesis of ubiquinones by malarial parasites. I. Isolation of [14C]ubiquinones from cultures of rhesus monkey blood infected with Plasmodium knowlesi. Biochemistry 8: 1284-1287.

Snow RW, Guerra CA, Noor AM, Myint HY, Hay SI 2005. The global distribution of clinical episodes of Plasmodium falciparum malaria. Nature 434: 214-217.

Spiro RG 2002. Protein glycosylation: nature, distribution, enzymatic formation and disease implications of glycopeptide bonds. Glycobiology 12: 43R-56R.

Sprenger GA, Schorken U, Wiegert T, Grolle S, de Graaf AA, Taylor SV, Begley TP, Bringer-Meyer S, Sahm H 1997. Identification of a thiamin-dependent synthase in Escherichia coli required for the formation of the 1-deoxy-D-xylulose 5-phosphate precursor to isoprenoids, thiamin, and pyridoxol. Proc Natl Acad Sci USA 94: 12857-12862.
Spurgeon SL, Porter JW 1981. Biosynthesis of isoprenoid compounds, vol. 1, Wiley, New York, p. 1-46.

Sullivan M, Li J, Kumar S, Rogers MJ, McCutchan TF 2000. Effects of interruption of apicoplast function on malaria infection, development and transmission. Mol Biochem Parasitol 109: 17-23.

Teclebrhan H, Olsson J, Swiezewska E, Dallner G 1993. Biosynthesis of the side chain of ubiquinone:trans-prenyltransferase in rat liver microsomes. J Biol Chem 268: 23081-23086.

Tonhosolo R, D’Alexandri FL, de Rosso VV, Gazarini ML, Matsumura MY, Peres VJ, Merino EF, Carlton JM, Wunderlich G, Mercadante AZ, Kimura EA, Katzin AM 2009. Carotenoid biosynthesis in intraerythrocytic stages of Plasmodium falciparum. J Biol Chem 284: 9974-9985.

Tonhosolo R, D’Alexandri FL, Genta FA, Wunderlich G, Gozzo FC, Eberlin MN, Peres VJ, Kimura EA, Katzin AM 2005. Identification, molecular cloning and functional characterization of an octaprenyl pyrophosphate synthase in intra-erythrocytic stages of Plasmodium falciparum. Biochem J 392: 117-126.

Tonhosolo R, Gabriel HB, Matsumura MY, Cabral FJ, Yamamoto MM, D’Alexandri FL, Sussmann RA, Belmonte R, Peres VJ, Crick DC, Wunderlich G, Kimura EA, Katzin AM 2010. Intraerythrocytic stages of Plasmodium falciparum biosynthesize menaquinone. FEBS Lett 584: 4761-4768.

Umeda T, Tanaka N, Kusakabe Y, Nakanishi M, Kitade Y, Nakamura KT 2010. Crystallization and preliminary X-ray crystallographic study of 1-deoxy-D-xylulose 5-phosphate reductoisomerase from Plasmodium falciparum. Acta Crystallogr Sect F Struct Biol Cryst Commun 66: 330-332.

Vial HJ, Philippot JR, Wallach DF 1984. A reevaluation of the status of cholesterol in erythrocytes infected by Plasmodium knowlesi and P. falciparum. Mol Biochem Parasitol 13: 53-65.

Walter RD 1986. Plasmodium falciparum: inhibition of dolichol kinase by mefloquine. Exp Parasitol 62: 356-361.

Wang K, Ohnuma S 1999. Chain-length determination mechanism of isoprenyl diphosphate synthases and implications for molecular evolution. Trends Biochem Sci 24: 445-451.

WHO - World Health Organization 2010. World Malaria Report, WHO, Geneva, 238 pp.

Wiesner J, Henschker D, Hutchinson DB, Beck E, Jomaa H 2002. In vitro and in vivo synergy of fosmidomycin, a novel antimalarial drug, with clindamycin. Antimicrob Agents Chemother 46: 2889-2894.

Wiesner J, Hintz M, Altincicek B, Sanderbrand S, Weidemeyer C, Beck E, Jomaa H 2000. Plasmodium falciparum: detection of the deoxyxylulose 5-phosphate reductoisomerase activity. Exp Parasitol 96: 182-186.

Zhang B, Watts KM, Hodge D, Kemp LM, Hunstad DA, Hicks LM, Odom AR 2011. A second target of the antimalarial and antibacterial agent fosmidomycin revealed by cellular metabolic profiling. Biochemistry 50: 3570-3577.

Zhang FL, Casey PJ 1996. Protein prenylation: molecular mechanisms and functional consequences. Annu Rev Biochem 65: 241-269.

Zhang K, Rathod PK 2002. Divergent regulation of dihydrofolate reductase between malaria parasite and human host. Science 296: 545-547. 
APÊNDICE D - Use of radioactive precursor for biochemical characterization the biosynthesis of isoprenoids in intraerythrocytic stages of Plasmodium falciparum 


\title{
Use of Radioactive Precursors for Biochemical Characterization the Biosynthesis of Isoprenoids in Intraerythrocytic Stages of Plasmodium falciparum
}

\author{
Emilia A. Kimura et al.* \\ Department of Parasitology, Institute of Biomedical Sciences, \\ University of São Paulo, São Paulo, \\ Brazil
}

\section{Introduction}

Malaria continues to be one of the major threats to human health, affecting 300-500 million people and causing the death of approximately 1 million individuals per year, mostly children under 5 years of age (WHO 2010b). Human malaria is caused by five species of the genus Plasmodium, namely Plasmodium falciparum, Plasmodium vivax, Plasmodium ovale, Plasmodium malariae and Plasmodium knowlesi, whereas the latter is found exclusively in the Southeast Asian region (Cox-Singh \& Singh 2008). Current estimates suggest that approximately 2.4 billion people are at risk of stable or unstable Plasmodium falciparum transmission, similar global estimates are also available for $P$. vivax, and while there is considerably less mortality attributed to this species, its geographical reach is far greater. An estimated 2.9 billion people are at risk for vivax malaria, with an estimated 80 million to 300 million clinical cases annually (Guerra et al., 2010). These global estimates are a direct result of an increasing ability to collate and assimilate large data sets that also allow the monitoring of trends in malaria incidence and parasite prevalence. $P$. falciparum is strongly associated with a potentially fatal form of the disease, although recent reports indicate an underestimation of the severity of $P$. vivax infections (Alexandre et al., 2010). Efforts were made to eradicate malaria and although these were successful over large geographical areas, they did not succeed in tropical Africa or in many parts of Asia. In the past few years, malaria has once again attracted more attention partly because of increasing recognition that the malaria prevalence in sub-Saharan Africa has increased during the past decade. The main cause of the worsened malaria situation recorded in recent years has been the spread of drug-resistant parasites, which has led to rising malariaassociated mortality, especially in east Africa.

\footnotetext{
* Gerhard Wunderlich, Fabiana M. Jordão, Renata Tonhosolo, Heloisa B. Gabriel,

Rodrigo A. C. Sussmann, Alexandre Y. Saito and Alejandro M. Katzin

Department of Parasitology, Institute of Biomedical Sciences,

University of São Paulo, São Paulo, Brazil
} 
The emergence of resistance occurs due to widespread and indiscriminate use of antimalarials. This fact exerts a strong selective pressure on malaria parasites to develop high levels of resistance. On the other hand, the spread of resistance is due to the existence of a sexual cycle in the invertebrate host where there is genetic exchange.

Antimalarial drug resistance is not the same as malaria treatment failure, which is the absence of success in clearing malarial parasitaemia and/or resolve clinical symptoms even with the administration of an antimalarial. While drug resistance may lead to treatment failure, not all treatment failures are caused by drug resistance. Treatment failure can also be the result of incorrect dosing, problems of treatment adherence, poor drug quality, interactions with other drugs, compromised drug absorption or misdiagnosis of the patient. Apart from leading to inappropriate case management, all these factors may also accelerate the spread of true drug resistance by exposure of the parasites to inadequate drug levels (WHO 2010b).

To assess if a strain is resistant to an antimalarial, the World Health Organization (WHO) recommended some methods: in vivo assessment of therapeutic efficacy; molecular genotyping to distinguish between re-infections and recrudescence; in vitro studies of parasite susceptibility to drugs in culture and identification of molecular markers.

Among the major antimalarial compounds recommended by WHO for treatment of malaria are the aminoquinolines (chloroquine, amodiaquine, primaquine, quinine, mefloquine), the antifolates (sulfadoxine), diaminopyrimidine (pyrimethamine), sesquiterpene lactones (artemisinin, artemether, artesunate) and some antibiotics (WHO 2010a). In counterpart, with the exception of artemisinin derivates, there is a widespread drug resistance confirmed to all these drugs in many malaria-endemic regions as shown in figure 1 (Ekland \& Fidock 2008).

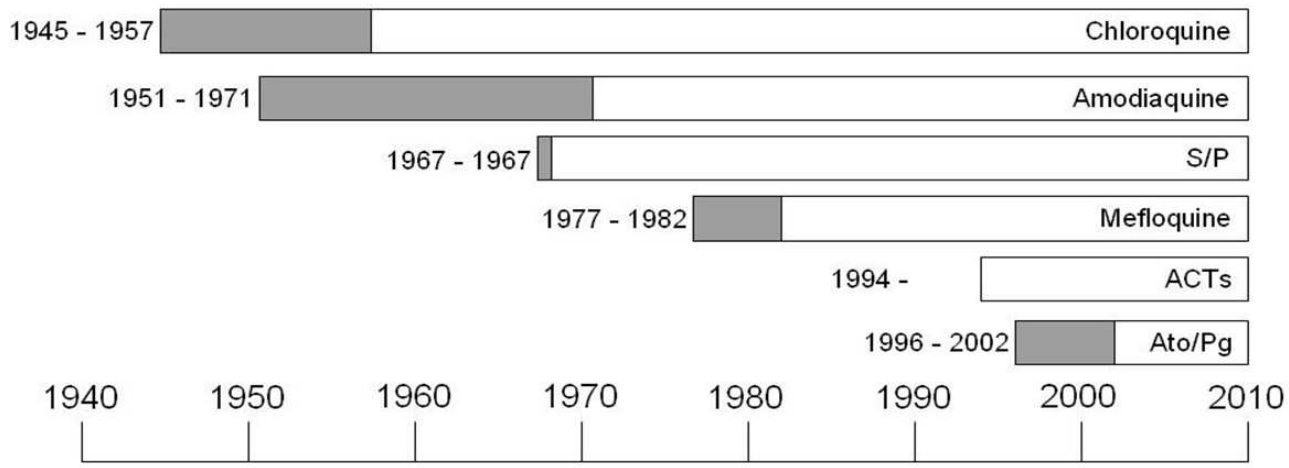

Fig. 1. Emergence of resistance to the principal antimalarials. Each bar represents an antimalarial monotherapy or combination. Years to the left of each bar represent the date the drug was introduced and the first reported instance of resistance. Chloroquine and sulfadoxine/ pyrimethamine remained effective for considerable periods after the first reported instances of resistance. Artemisinin-based combination therapies (ACTs); atovaquone/proguanil (Ato/Pg); sulfadoxine/pyrimethamine (S/P), (Adapted from Ekland \& Fidock., 2008). 
Field trials of artemisinin (Qinghaosu) and its derivates were first implemented in China in the early 1970s. Artemisinin has a low radical cure rate when used alone in a short course, presumably due to its very short half-life in vivo. Since 1994, artemisinin and its derivates have been used in combination therapies (ACTs). More recently, in reports about the molecular marker SERCA-type PfATPase6 associated to artemisinin-derivate resistance was described as possible target of the drug (Eckstein-Ludwig et al., 2003), but some groups do not agree about the correlation of mutation of this gene to the artemisinin (Dondorp et al., 2009; Valderramos et al., 2010).

Several strategies have been used to control malaria in the world, and these rely on the efficient and fast treatment of infected individuals, environmental measures including vector control programs and prevention by the stimulation of use of insecticide-treated bednets (WHO 2010b). Given the ever-looming surge of resistance of the parasite against the drugs currently in use, the development of an efficient vaccine or novel drugs are important issues.

The symptoms of malaria are linked to the stage of schizogony. After the invasion of erythrocyte the parasite consumes and destroys the intracellular proteins, especially hemoglobin which is polymerized into an inert substance denominated hemozoin or malarial pigment. According to classical symptomatology, fever coincides with lysis of red blood cells (RBCs) and is caused by the release into the bloodstream of the hemozoin and other toxic parasite products. Coincident with the rupture of erythrocyte occurs the increased expression of TNF- $\alpha$ and other cytokines (TNF- $\beta$ and IL-6) which can also induce the release of other mediators (prostaglandin and TGF- $\beta$ ) that are responsible for the onset of symptoms (including fever) and tissue damage (Beeson \& Brown 2002; Hemmer et al., 2006).

P. falciparum is strongly associated with a potentially fatal form of the disease, most affecting young children, non-immune adults and pregnant women, although recent reports indicate an underestimation of the severity of $P$. vivax infections (Alexandre et al., 2010). The pathogenesis of human $P$. falciparum infection is a complex interaction of parasite induced RBCs alterations (Maier et al., 2009) and microcirculatory anomaly, (Grau et al., 2003) accompanied by local and systemic immune reactions, resulting in a accumulation or sequestration of parasite infected RBCs in various organs, such as the brain, lung and placenta, and together with other factors is important in the pathogenesis of severe forms of malaria (Marsh et al., 1995; Buffet et al., 2011). RBC infected with early parasite stages (rings) display mild modifications of adhesion and/or deformability properties and may circulate, whereas late parasite stages, called trophozoites and schizonts (mature forms), have substantial alterations of adhesion and deformability that favor their sequestration in small vessels, thus preventing their circulation in the peripheral blood. Sequestration of mature forms is induced by their adherence to endothelial cells, blood cells, platelets, and uninfected RBCs. These interactions are mediated by multiple host receptors recognized by parasite adhesins (Maier et al., 2009). Cerebral malaria is the main clinical manifestation of severe $P$. falciparum infection and seems to be responsible for most deaths. It is characterized by coma, often with convulsions (Lalloo et al., 1996). Severe anaemia is probably the second most common presentation of severe $P$. falciparum infection and probably results from RBCs destruction, indirect destruction of parasitized erythrocytes by immune mechanisms and reduced erythropoiesis associated with imbalances in cytokine concentrations (Menendez et al., 2000; Ekvall 2003). Renal dysfunction or failure, circulatory collapse and shock, disseminated intravascular coagulation and spontaneous bleeding, and acidosis can also occur. Among adults with malaria, pregnant women are particularly susceptible to malaria, 
despite substantial immunity before pregnancy, and the risk is highest in first pregnancies. The major complications of infection are maternal anaemia, which in turn increases maternal deaths, and reduced infant birthweight from a combination of intrauterine growth retardation and premature delivery leading to excess infant mortality. In some settings maternal malaria may also cause spontaneous abortion or stillbirth (Granja et al., 1998).

Severe clinical forms are uncommon in infections with P. vivax however in countries where this parasite is dominating, more and more frequently is becoming common severe cases and even deaths to P. vivax infection are reported (Anstey et al., 2009). In Brazil cases such as severe rhabdomyolysis (Siqueira et al., 2010) and immune thrombocytopenic purpura have been reported (Lacerda et al., 2004) and in south-east Asia, especially in India and Vietnam, cases of acute renal failure were documented (Sanghai \& Shah 2010). A serious problem encountered in the P. vivax infection are hypnozoites, this liver stage that can cause relapses many months or even years after the initial infection, and these hypnozoites can only be eliminated by additional treatment with primaquine (Watkins \& Sibley 2011).

\section{The life cycle of plasmodium}

Laveran was responsible for the discovery of the Plasmodium, observing them in human erythrocytes and was the first to describe it in 1880. The life cycle of parasites of humans Plasmodium genus is very similar between species, showing two distinct phases. The life cycle of malaria parasite is complex, and there are four critical points in the life cycle of Plasmodium parasites in which a small number of parasites rapidly multiply to generate much larger populations. These life cycle stages are male gamete development, sporozoite formation, liver stage development and blood stage asexual reproduction. The first two of these processes occur within the mosquito vector, and the second two processes take place in the vertebrate host.

Infective sporozoites from the salivary gland of the Anopheles mosquito are injected into the human host along with anticoagulant-containing saliva to ensure an even-flowing blood meal. Once entered in the human bloodstream, P. falciparum sporozoites reach the liver and penetrate the liver cells where they remain at for 9-16 days and undergo asexual replication known as exo-erythrocytic schizogony. Each sporozoite gives rise of thousands of merozoites inside the hepatocyte and each merozoite can invade a red blood cell (RBC) upon release from the liver. According to the Plasmodium species, the liver phase takes on average 6 days (P. falciparum), 10 days (P. vivax), or 15 days (P. ovale and P. malariae).

Merozoites enter erythrocytes by a complex invasion process, requiring a series of highly specific molecular interactions. Asexual division starts inside the erythrocyte and the parasites develop through different stages therein. The early trophozoite stage is often referred to as the "ring form". Trophozoite enlargement is accompanied by highly active metabolism. The end of this stage is marked by multiple rounds of nuclear division withouth cytokinesis resulting in the formation of schizonts. Each mature schizont contains up to 32 merozoites and these are released after lysis of the RBC to invade further uninfected RBCs. This release coincides with the sharp increases in body temperature during the progression of the disease. This cycle takes about $36-48 \mathrm{~h}$ in P. falciparum, $48 \mathrm{~h}$ in $P$. vivax and $P$. ovale and $72 \mathrm{~h}$ in $P$. malariae. A small proportion of the merozoites in the RBCs eventually differentiate to produce micro and macrogametocytes. These gametocytes are essential for transmitting the infection to new hosts through female Anopheles mosquitoes. 
A mosquito taking a blood meal on an infected individual may ingest these gametocytes into its midgut, where macrogametocytes form macrogametes and exflagellation of microgametocytes produces microgametes. These gametes fuse, undergo fertilization and form a zygote. This transforms into an ookinete, which penetrates the wall of a cell in the midgut and develops into an oocyst. Inside the oocyst many nuclear divisions occur, resulting in thousands of sporozoites and they migrate to the salivary glands for onward transmission into another host.

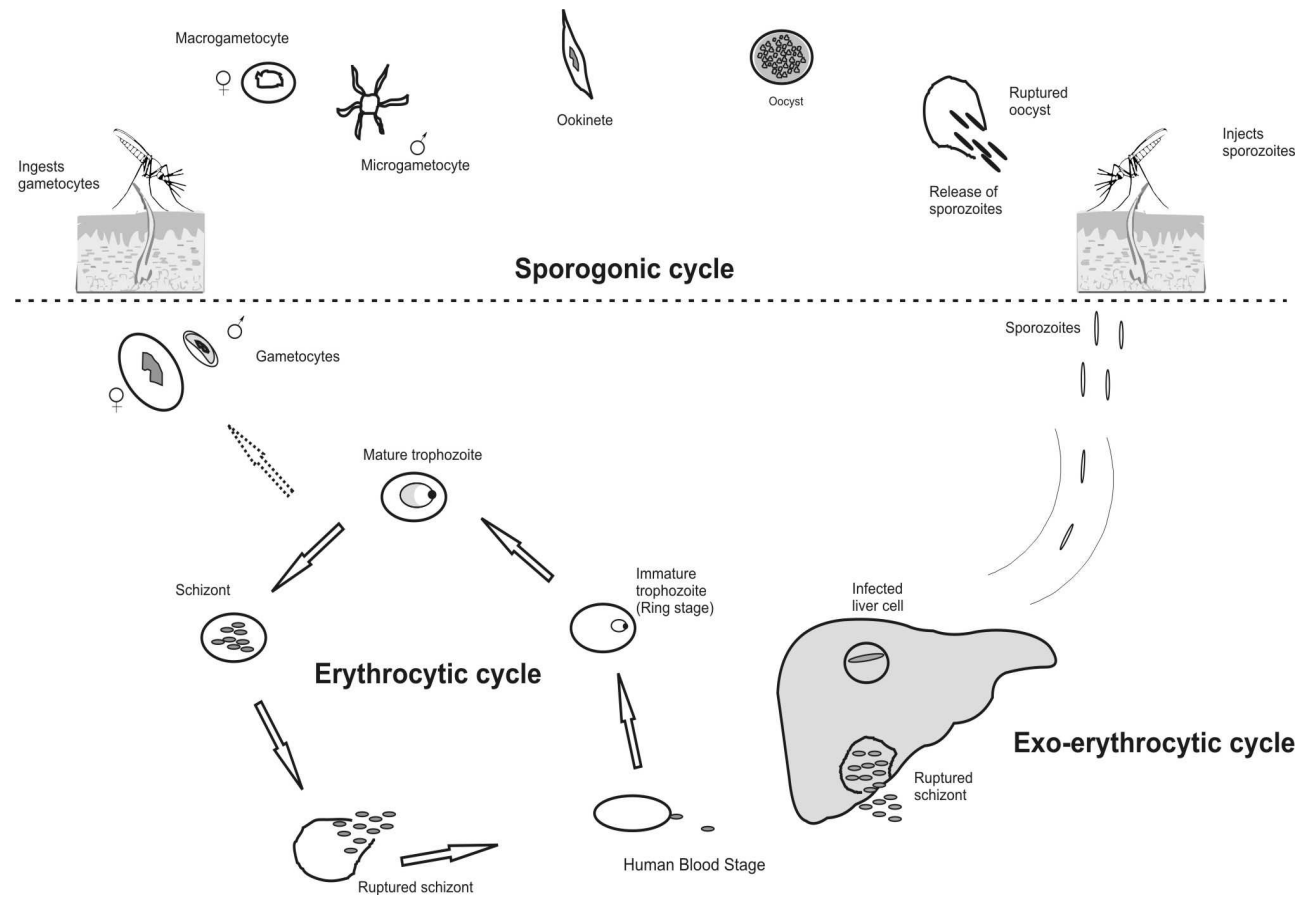

Fig. 2. During a blood meal, the mosquito inoculates sporozoites into the human host, infecting the liver cells initiating the exo-erythrocytic cycle. The parasites multiply, forming the schizonts, which then rupture releasing merozoites. The merozoites infect red blood cells, initiating the erythrocytic cycle (differentiating into ring, trophozoite and schizont); after the rupture of the red blood cells that contain them, merozoites are released and invade other red blood cells; some parasites differentiate into male (microgametocytes) and female (macrogametocytes) sexual forms the mosquitoes, by feeding off infected patients, ingest the gametocytes; the gametocytes evolve into gametes, and the microgametes penetrate the macrogametes generating zygotes, which in turn evolve into motile ookinetes; these invade the midgut wall of the mosquito, where they develop into oocysts; where sporogony takes place, releasing sporozoites; these migrate to the mosquito salivary gland.

The erythrocytic stages of the malaria parasite are responsible for the symptoms and pathology of the disease (Miller et al., 1994). Immunity against the erythrocytic stages is not well understood, although they are important from the vaccine development perspective (Good 2001). To a greater or lesser extent, all four species have been cultured or maintained 
in vitro; P. falciparum, however, is the only species for which all life cycle stages have been established in culture (Hollingdale 1992).

Cultivation of the intraerythrocytic stages of $P$. falciparum is vital for many aspects of malaria research. The in vitro continuous cultivation of the erythrocytic stages of $P$. falciparum achieved by (Trager \& Jensen 1976) was a turning point in the history of malaria research. Since the establishment of this technique and refinements thereafter, the pace of research on malaria has increased significantly.

The methods for cultivation of the erythrocytic stages of $P$. falciparum reported have been usefully applied in nearly every aspect of research on malaria: chemotherapy, drug resistance, immunology and vaccine development, pathogenesis, gametocytogenesis and mosquito transmission, genetics, the basis for resistance of certain mutant red cells, cellular and molecular biology and biochemistry of the parasites and of their relationship with their host erythrocyte (Trager \& Jensen 1997).

Although several methods have been developed, the technique used for the in vitro culture of the intraerythrocytic stages of $P$. falciparum remains essentially the same as that originally described by Trager and Jensen. The protocol described by these authors was based on the use of HEPES (4-(2-hydroxyethyl)-1-piperazineethanesulfonic acid)-buffered RPMI tissue culture medium supplemented with human serum, erythrocytes and sodium bicarbonate. Since then, efforts and time have been invested in trying to improve the in vitro growth of the asexual stages of the Plasmodium life cycle.

The availability of the technique has also spawned efforts to cultivate other malaria pathogens, both human and non-human. In most instances, it is more convenient working with malarial parasites from non-human hosts because they can be maintained in vivo, thereby allowing testing for infectivity of in vitro-cultured stages in the vertebrate host and providing an animal model for the study of the parasite in the human host, is as the case culture malarial parasites infecting simian, avian, and rode hosts.

Techniques for cultivation of the exoerythrocytic stages of avian malarial parasites $P$. gallinaceum, P. lophurae, and P. fallax were described by Huff (Huff 1964). Primary cultures of hepatocytes from rhesus monkeys (Macaca mulatta) were used to support growth of several simian malarias (P. cynomolgi, P. knowlesi, P. coatneyi, and P. inui) (Millet et al., 1988). In a later study, the same group used rhesus hepatocytes for cultivation of developmental stages of $P$. fieldi and $P$. simiovale, two parasites that infect macaques (Millet et al., 1994). Erythrocytic development of a number of simian malarial parasites has been studied, including that of P. knowlesi, P. cynomolgi, P. fragile, P. gonderi, P. coatneyi, P. inui, P. fieldi, and $P$. simiovale. Some of these aforementioned malarias are non human facsimiles of human malarias. Among the rodent malarias, the erythrocytic stages of $P$. berghei and $P$. chabaudi have been cultivated in vitro (Mons et al., 1983; O'Donovan \& Dalton 1993). The rodent malarial parasite $P$. berghei from in vivo-infected livers was maintained in primary cultures of rodent liver cells by Foley et al. (Foley et al., 1978). Among the avian malarias, the erythrocytic stage of $P$. lophurae has been cultivated in vitro (Langreth \& Trager 1973).

\section{Characterization of Isoprenoid pathway by metabolic labeling}

Widespread resistance to most anti-malarial drugs and the unavailability of an effective vaccine have fueled the emergence of malaria in recent years as a major global health and economic burden. Despite these hurdles, the field of malaria research has witnessed some extremely notable developments in the recent past including sequencing of the malaria 
genome (Gardner et al., 2002) the application of proteomics to studying malaria life cycle (Florens et al., 2002), the malaria transcriptome (Bozdech et al., 2003), and several web resources such as Mal-Vac (database of malaria vaccine candidates), PlasmoDB (genome database of the Plasmodium genus), and VarDB (database for antigenic variation genes families) (Chaudhuri et al., 2008; Hayes et al., 2008; Aurrecoechea et al., 2009).

A thorough knowledge of the biochemistry of $P$. falciparum is required in order to develop new drugs. This aim can be achieved by two means: either by focusing on validated targets in order to generate new drug candidates; or by identifying new potential targets for malaria chemotherapy. This last strategy will be commented and discussed in this chapter, focusing on the biosynthesis of isoprenoids. In the apicomplexan parasites of the genus Plasmodium the isoprenoid pathway is localized in the apicoplast which was acquired millions of years ago during an evolutionary event (Lim \& McFadden 2010). At this occasion, the ancestor of the phylum apicomplexa gained a plastid by the secondary endosymbiosis of a photosynthetic eukaryote (McFadden et al., 1996). The chloroplast of this photosynthetic eukaryote was retained and during evolution, many chloroplastid genes were transferred to the apicomplexan nucleus while others were lost (Funes et al., 2002; Moore et al., 2008). In the case of malaria parasites, especially its most virulent species $P$. falciparum, a series of new "plant-like" enzymes associated with this organelle were recently discovered (Luo et al., 1999).

When testing for metabolic activities, usually the cultivable blood stage forms of $P$. falciparum are employed (Trager \& Jensen 1976), that we will describe briefly below. Since the parasite is an obligate intracellular organism in this stage, several precautions must be taken to not confound host cell and parasite metabolic activities. Also, the chemical nature of an unlabeled or radiolabeled precursor plays an important role, since some substrates do not enter the red blood cell or do not cross the parasitophorous vacuole or the parasite cell membrane. Other substrates may require solvents which are toxic to either the parasite or the red blood cell. In the following, we describe the progress that was made in the detection of a number of metabolic activities of the parasites, many of which configure prime targets for drug intervention.

One of the strategies to identify each product of a metabolic pathway is the metabolic labeling using a radioactive specific precursor and a posterior analysis by an appropriate method. Due to the difficulty to obtain higher quantities of parasite biomass, the labeling with non-radioactive isotopes often does not lead to clear results, for this reason, most research groups rely on radiolabeled compounds when monitoring metabolic turnover. Several criteria must be evaluated before proceeding to experimental metabolic labeling of intraerythrocytic stages of $P$. falciparum: 1- determine type of study (structural or biosynthetic), 2- choose labeling protocol and select a radiolabeled precursor(s), 3- check incorporation of radioactivity into the parasite, 4- if the incorporation is sufficient for analysis, proceed with steady-state, pulse, pulse-chase or sequential transfer protocols for analysis of intermediates of the metabolic pathway to be studied. If incorporation is insufficient for analysis, it is recommended to try using more labeled precursor or decrease the level of unlabeled precursor in the culture medium. In the next step, it is advantageous to check effects on the parasite and molecule(s) of interest and effects on incorporation of labeled precursors. Afterwards, the optimal concentration of unlabeled precursor is selected and the experiment may proceed with steady-state, pulse, pulse-chase or sequential transfer protocols for the analysis of intermediates of the metabolic pathway that is studied. 
For the characterization the composts isoprenics in parasite, P. falciparum clone 3D7 was cultured according to the protocol described by Trager and Jensen (Trager \& Jensen 1976) where human sera was substituted by Albumax I (0.5\%). Parasites were grown in tissue culture flasks $\left(75 \mathrm{~cm}^{2}\right)$ a $40 \mathrm{ml}$ volume with a gas mixture of $5 \% \mathrm{CO}_{2}, 5 \% \mathrm{O}_{2}$, and $90 \% \mathrm{~N}_{2}$. In asynchronous cultures we can to obtain the ring, trophozoite or schizont stages. In synchronous cultures ( $\sim 15 \%$ parasitemia), the stage initially was in ring stage $(1-20 \mathrm{~h}$ after reinvasion) after two treatments with $5 \%(\mathrm{w} / \mathrm{v})$ D-sorbitol solution in water, for subsequent maintenance in culture until the differentiation to trophozoite (20-30 h after reinvasion) or schizont (30-35 h after reinvasion) stages. Parasite development and multiplication were monitored by microscopic evaluation of Giemsa-stained thin smears.

Cultures of $P$. falciparum with a parasitemia of approximately $10 \%$ were labeled with the different precursors in normal RPMI 1640 medium for $15 \mathrm{~h}$ and after each stage purified. The asynchronous parasites were purified on a $40 \% / 70 \% / 80 \%$ discontinuous Percoll ${ }^{\circledR}$ gradient (Braun-Breton et al., 1986). The culture was centrifuged at $2000 \mathrm{rpm}$ for $5 \mathrm{~min}$ at room temperature, the pellet resuspended in RPMI-1640 (1:1 vol/vol), and carefully placed on top of the gradient. The tubes were centrifuged at $10,000 \times \mathrm{g}$ for $20 \mathrm{~min}$ at $20^{\circ} \mathrm{C}$. The cells containing schizonts, trophozoite and ring stages, respectively were collected, washed twice in RPMI-1640, the pellet of parasites were stored in liquid $\mathrm{N}_{2}$ for subsequent analysis. The other hand, synchronous culture with schizont stages predominantly were purified with magnetic column separation (MACS Separation Columns "CS"). The pre-equilibration, washing, and elution the column were all carried out at room temperature with RPMI-1640. The culture was centrifuged, the pellet resuspends in RMPI-1640 (1:10 vol/vol), $10 \mathrm{ml}$ of the $10 \%$ suspension of erythrocytes were applied to a CS column assembled in a magnetic unit to remove non-infected erythrocytes, ring-infected erythrocytes, and young trophozoites. After wash the column by filling from top with $50 \mathrm{ml}$ of RMPI-1640, the column was removed from the magnetic field and its contents eluted with $50 \mathrm{ml}$ of RMPI-1640, thus, the schizonts stages fraction were obtained, centrifuged at 2,000 rpm for $5 \mathrm{~min}$ at room temperature, the supernatant discarded, and the pellet of parasites were stored in liquid $\mathrm{N}_{2}$ for subsequent analysis. Parasite form was monitored by microscopic evaluation of Giemsastained thin smears.

In the following, we specifically focus i) on the methylerythritol phosphate (MEP) pathway which leads to the isoprenoids isopentenyl pyrophosphate (IPP) / dimethylallyl pyrophosphate (DMAPP) and ii) on downstream reactions which result in dolichol, ubiquinone, menaquinone, tocopherol, carotenoids and other related compounds.

\section{Mevalonate-independent methylerythritol phosphate (MEP) pathway in P. falciparum}

The MEP pathway starts with the condensation of pyruvate and glyceraldehyde-3-phosphate, which yields 1-deoxy-D-xylulose-5-phosphate (DOXP) as a key metabolite (Rohmer et al., 1993). Cassera and colleagues showed by metabolic labeling that the MEP pathway is functionally active in the intraerythrocytic stages of $P$. falciparum. Using different radioactive precursors such as $\left[1-{ }^{14} \mathrm{C}\right]$ sodium acetate, $\mathrm{D}-[\mathrm{U}-14 \mathrm{C}]$ glucose and $\left[2-{ }^{14} \mathrm{C}\right]$ deoxy-D-xylulose, five intermediates of the MEP pathway were identified. The intermediates were isolated by high performance liquid chromatography (HPLC) and characterized by electrospray mass spectrometric analyses. All but one of the intermediates of the MEP pathway were characterized, including 1-deoxy-D-xylulose-5- phosphate, 2-C-methyl-D-erythritol-4- 
phosphate, 4-(cytidine-5-diphospho)-2-C-methyl-D-erythritol, 4-(cytidine-5-diphospho)-2-Cmethyl-D-erythritol-2-phosphate, and 2-C-methyl-D-erythritol-2,4-cyclodiphosphate. The effect of fosmidomycin on the levels of MEP pathway intermediates was found to be most prominent in ring stages followed by schizont stages of $P$. falciparum. It was also shown that the MEP pathway provides IPP precursors for the synthesis of higher isoprenic compounds like ubiquinone and dolichol, and this was demonstrated by the decrease in the ubiquinone and dolichol content in fosmidomycin-treated parasites (Cassera et al., 2004). To achieve efficient labeling, $\left[1-{ }^{14} \mathrm{C}\right]$ sodium acetate and $\mathrm{D}-\left[\mathrm{U}-{ }^{14} \mathrm{C}\right]$ glucose were employed instead of pyruvic acid, which is not incorporated by blood stage $P$. falciparum. These relatively simple compounds which enter in many biochemical pathways obviously require a refined analysis of synthesized molecules and this was achieved by demonstrating the chemical nature of the found molecules by different analytic methods.

\section{Detection of $\mathbf{N}$-linked glycoproteins in $\boldsymbol{P}$. falciparum}

Glycoconjugates have been shown to be important in the penetration, cellular growth, host immunity regulation and differentiation (Schwarz \& Datema 1982). The presence of glycoproteins in $P$. falciparum has been demonstrated in several studies but remains controversial because there is little information addressing the function of $P$. falciparum glycoconjugated molecules. Also, the few available studies are inconsistent due to differing methodologies. N-linked glycosylation is a protein modification that occurs co-translationally in the endoplasmic reticulum. Kimura and colleagues described briefly the methodology used for detection of $\mathrm{N}$-linked glycoproteins. For this purpose parasite culture containing ring stage parasites were labeled for 48 hs with D-[U-14C]glucose or D-[U-14C]mannose. The metabolic labeling was also done in the presence of $12 \mu \mathrm{M}$ tunicamycin, the classic inhibitor of $\mathrm{N}$ glycosylation. The total profile of glycoproteins was analyzed by SDS-PAGE of treated and untreated parasites. The N-linked glycoproteins were confirmed by $18 \mathrm{~h}$ radiolabeling with L[35S]methionine and affinity chromatography using Concanavalin A-Sepharose. In parallel, tunicamycin pre-treated parasites showed a differing band pattern, thus identifying protein species which carried N-glycosyl moieties. In order to increase L-[35S]methionine or D-[U-14C] glucose labeling, the cultures were starved in methionine- or glucose-deficient medium for $1 \mathrm{~h}$ before the addition of the radioactive substance (Kimura et al., 1996). By this approach, these authors identified N-linked glycoprotein when they used the radioactive precursor D-[U${ }^{14} \mathrm{C}$ ]glucose. As above, although this form of labeling is unspecific, other methodologies confirmed the nature the compounds where radioactive glucose became incorporated. On the other hand, Dieckmann-Schuppert et al. (1992) did not detect N-linked glycoproteins using the specific 2-[3H]mannose, 6-[3H]glucosamine, or 1-[14C]mannosamine. In 1997 Gowda and colleagues confirmed that $P$. falciparum contains low levels of $N$-glycosylation activity. The amount of $\mathrm{N}$-linked carbohydrates in whole parasite proteins is approximately $6 \%$ compared with the GPI anchors attached to proteins based on radioactive GlcN incorporated into the proteins (Gowda et al., 1997). Bushkin et al. (2010) suggested that the occupation of N-glycan sites is markedly reduced in apicoplast proteins versus some secreted proteins in Plasmodium. Clearly, more work has to be done in order to elucidate the nature and purpose of N-linked glycoproteins in Plasmodium. Also, the differences in the results published by distinct groups mentioned above may have occurred due to differences in basic aspects of each experiment, such as the duration of labeling, the tracing compound used and the parasite stage that was analyzed. 


\section{Characterization of dolichol in P. falciparum}

The protein modification by $\mathrm{N}$-linked glycosylation is dependent on the de novo synthesis of dolichyl-P, a long chain non-sterol isoprene which acts as a membrane-bound carrier of oligosaccharides in the assembly of glycoproteins (Leloir 1977). Couto et al (1999) demonstrated the presence of dolichol, dolichyl-P and dolichyl-PP species of 11 and 12 isoprenic units in parasites of $P$. falciparum cultivated in vitro.

In these experiments, cultures of $P$. falciparum were labeled for $15 \mathrm{~h}$ with [1-(n)$\left.{ }^{3} \mathrm{H}\right]$ geranylgeranyl pyrophosphate triammonium salt ([1-(n)-3H]GGPP) or with [1-(n)$\left.{ }^{3} \mathrm{H}\right]$ farnesyl pyrophosphate triammonium salt $\left(\left[1-(n)-{ }^{3} \mathrm{H}\right] \mathrm{FPP}\right)$. Each stage was purified by Percoll gradient; the pellets were extracted and analyzed by C18 reverse-phase HPLC (RPHPLC). From extracts labeled with [1-(n)-3 $\left.{ }^{3} \mathrm{H}\right]$ GGPP, 3 major peaks were detected: at 8 min, coincident with an authentic sample of geraniol, at $21 \mathrm{~min}$, coincident with a dolichol standard with 11 isoprenic units and at $23 \mathrm{~min}$, coincident with a dodecaprenol standard. Parasites labeled with [1-(n)- $\left.{ }^{3} \mathrm{H}\right] \mathrm{FPP}$ showed a number of other labeled products, but the presence of dolichol of 11 and 12 isoprenic units was evident (Couto et al., 1999).

\section{Characterization of ubiquinone and carotenoids in $P$. falciparum}

Coenzyme $\mathrm{Q}$ is a molecule composed of a benzoquinone ring with a side chain of several isoprenic units, and the number of which defines the type of coenzyme $Q$. A polyprenyl diphosphate synthase is involved in the elongation of the side chain (Ogura et al., 1997). This isoprenic chain is then attached to p-hydroxybenzoic acid (PHBA), which is synthesized via the shikimate pathway. The isoprenic chain then allows the molecule to attach to the inner membrane of mitochondria, where it participates in many metabolic processes, like the electron transport chain (Ernster \& Dallner 1995).

Macedo et al. (2002) had identified coenzyme Q8 and coenzyme Q9 by metabolic labeling of parasites with [1-14C]acetic acid, [1-14C]isopentenyl pyrophosphate triammonium salt ([1$\left.\left.{ }^{14} \mathrm{C}\right] \mathrm{IPP}\right),[1-(\mathrm{n})-3 \mathrm{H}] \mathrm{FPP}$, and [1-(n)-3H]GGPP in all intraerythrocytic stages. To our knowledge, this was the first report on the incorporation of $[1-14 \mathrm{C}] \mathrm{IPP}$ into P. falciparum. It is well known that the considerable increase in total lipid content associated with $P$. falciparum invasion is due to the existence of an intense lipid transport system in infected erythrocytes. The efficient uptake of [1-(n)-3 $\left.{ }^{3}\right]$ FPP, $\left[1-(n)-{ }^{3} \mathrm{H}\right] \mathrm{GGPP}$ and, to a lesser extent, $\left[1-{ }^{14} \mathrm{C}\right] \mathrm{IPP}$, may be ascribed to this transport mechanism for lipid-like components. The parasite is capable of synthesizing two different homologues of coenzyme $Q$, depending on the given radioactive intermediate. When labeling is performed with $[1-(n)-3 \mathrm{H}] \mathrm{FPP}$, coenzyme $\mathrm{Q}$ with an isoprenic chain of 40 carbons (Q8) is detected; while [1-(n)- ${ }^{3} \mathrm{H}$ ]GGPP labeling leads to Q9 (45 carbons) chains. These findings can be explained by the fact that both FPP and GGPP are substrates of the prenyltransferase involved in the biosynthetic pathway of the isoprenic chain of ubiquinone as shown in other systems (Ogura \& Koyama 1998). This difference in the length of the isoprenic chain according to the precursor was also observed in the biosynthesis of dolichols in P. falciparum. In order to check whether this difference could be induced by the length of the isoprenoid intermediate, the basic isoprenic unit [1-14C]IPP was used as a metabolic marker. It would be expected that by labeling with [1-14C]IPP, both coenzymes Q would be detected. Surprisingly, HPLC analysis showed a single radioactive peak, which co-eluted with a coenzyme Q9 standard. The enzyme of $P$. falciparum (www.PlasmoDB.org, entry PfB0130w) that biosynthesizes the isoprenic chain attached to 
benzoquinone ring of coenzyme $\mathrm{Q}$ was cloned and expressed and showed octaprenyl pyrophosphate synthase activity. Enzymatic activity was measured by determination of the amount of [1-14C]IPP incorporated into butanol-extractable polyprenyl diphosphates. The recombinant and native versions of the enzyme had similar Michaelis constants with the substrates $\left[1-{ }^{14} \mathrm{C}\right] \mathrm{IPP}$ and farnesyl pyrophosphate. The initial rate was calculated by determining the quantities of product formed or IPP consumed at each time point by counting the ${ }^{14} \mathrm{C}$ radioactivity in the butanol phase (product) and in the aqueous phase (IPP). The recombinant protein, as well as P. falciparum extracts, showed an octaprenyl pyrophosphate synthase activity, with the formation of a polyisoprenoid with eight isoprenic units, as detected by reverse-phase HPLC and reverse-phase TLC, and confirmed by electrospray ionization and tandem MS analysis. Additionally, the recombinant enzyme could be competitively inhibited in the presence of the terpene nerolidol. Since the $P$. falciparum enzyme shows quite low similarity to its human counterpart, decaprenyl pyrophosphate synthase, it was suggested that the identified enzyme and its recombinant version could be exploited in the screening of novel drugs (Tonhosolo et al., 2005). The enzyme octaprenyl pyrophosphate synthase (PfB0130w) turned out to be a bi-functional enzyme with phytoene synthase activity, which was shown by in vitro enzymatic assays using [1-(n)-3H]GGPP as a substrate, followed by HPLC analysis and confirmation by LCAPCI-MS/MS analysis. The identification of the enzyme phytoene synthase showed that intraerythrocytic stages of $P$. falciparum can perform the crucial step of the pathway that leads to the biosynthesis of carotenoids. Carotenoids are widespread lipophilic pigments synthesized by all photosynthetic organisms and some nonphotosynthetic fungi and bacteria. All carotenoids are derived from the C40 isoprenoid precursor geranylgeranyl pyrophosphate. HPLC analysis from extracts of intraerythrocytic stages of $P$. falciparum labeled with [1-(n)- $\left.{ }^{3} \mathrm{H}\right]$ GGPP, revealed several compounds in all intraerythrocytic stages, with retention times coincident with lutein, phytoene, phytofluene, all-trans- $\beta$-carotene, neurosporene and 6-all-trans-lycopene. Some of these compounds were structurally characterized by electrospray mass spectrometric analysis (Tonhosolo et al., 2009).

Considering that carotenoid biosynthesis is absent in humans, and also that possibly other uncharacterized carotenoid synthesizing enzymes are present, in Plasmodium, it possible to speculate that this pathway could be exploited for the design of new antimalarial drugs. Indeed, sequence data from additional organisms, functional studies, improved bioinformatics screening approaches, together with biochemical evidence, may reveal whether other interesting targets and pathways are present in the phylum Apicomplexa.

\section{Vitamin E biosynthesis}

The biosynthesis of vitamin E depends on both the MEP and shikimate pathways. This compound consists of a polar chromanol head group attached to a hydrophobic phytyl (tocopherols) or geranylgeranyl (tocotrienols) tail, both of which are critical for their roles as lipid-soluble antioxidants (Schneider 2005).

Using [1-(n)-3 H]GGPP or [1-(n)-3H]FPP as radiotracer precursors and HPLC systems for purification of vitamin $\mathrm{E}$, the biosynthesis of a and $\gamma$-tocopherol was detected in the three intraerythrocytic stages from $5 \times 10^{8}$ parasites. To confirm the chemical identity of these compounds, unlabeled extracts from $10^{10}$ parasites were purified by HPLC, the retention time of tocopherol isomers was collected and analyzed by gas chromatography coupled to a 
mass spectrometer (GC-MS). Although the two isomers were found in parasites as well as in erythrocytes and culture medium extracts, the parasite extracts showed higher concentrations than the other samples (Sussmann 2010).

Usnic acid is a secondary metabolite from lichens and capable to inhibit the 4hydroxyphenylpyruvate dioxygenase, an enzyme from the shikimate pathway which is responsible for the biosynthesis of homogentisate from hydroxyphenylpyruvate. Homogentisate is the aromatic portion which receives the isoprenoid side chain from MEP pathway to form vitamin E isomers. When labeled parasites are treated with $25 \mu \mathrm{M}$ of usnic acid, the biosynthesis of a and $\gamma$-tocopherol was inhibited in 53,5 \pm 7\% (Sussmann 2010).

\section{Menaquinone biosynthesis}

In plants and cyanobacteria the shikimate pathway and MEP provide the precursors for the biosynthesis of phylloquinone (PhQ) while in bacteria menaquinone is synthesized (Lombardo et al., 2006). Tonhosolo et. al. (2010) showed by metabolic labeling with the precursor [1-(n)-3 $\mathrm{H}$ ]GGPP that intraerythrocytic stages of $P$. falciparum biosynthesizes menaquinone (MQ-4), employing different chromatographic methods reported for this type of molecule and further confirmed the nature of the molecules by ESI-MS/MS analysis. Additionally, they showed that the mycobacterial inhibitor of menaquinone synthesis Ro 488071 also suppressed MQ biosynthesis and growth of parasites, pointing possibly again to an interesting drug target.

\section{Posttranslational modification}

\subsection{Protein farnesylation and geranylgeranylation in $P$. falciparum}

Post-translational modification of proteins with isoprenoids was first recognized as a general phenomenon in 1984 (Schmidt et al., 1984). The isoprenyl group is linked postranslationally to cysteine residues at the C-terminus of the protein through a thioether bound (McTaggart 2006). Studies have shown that FPP (15 carbons) and GGPP (20 carbons) are the most common isoprenoids found attached to proteins. Several of the proteins that undergo these modifications have been identified and may participate in important cell regulatory functions, particularly signal transduction pathways (Zhang \& Casey 1996). Protein prenylation is a general phenomenon in eukaryotic cells and has also been described for several protozoan parasites (Lujan et al., 1995; Field et al., 1996; Shen et al., 1996; Ibrahim et al., 2001) including P. falciparum (Chakrabarti et al., 2002).

In order to investigate the presence of isoprenylated proteins in P. falciparum, the labeled intermediates [1-(n)-3 $\left.{ }^{3} \mathrm{H}\right] \mathrm{FPP}$ and [1-(n)-3 $\left.{ }^{3} \mathrm{H}\right]$ GGPP were used. Parasites were incubated with radioactive for $18 \mathrm{~h}$, purified on a Percoll gradient, lysed, and analyzed by SDS/PAGE and autoradiography. [1-(n)-3H]GGPP labeled proteins appeared in the ring, trophozoite, and schizont stages. Non-infected red blood cells showed no incorporation of radioactivity under these conditions. The isoprenylated proteins were later identified as members of the Ras and Rab protein family (Rodrigues Goulart et al., 2004).

Moura et al. (2001) and Rodrigues Goulart et al. (2004) showed that terpenes can inhibit protein isoprenylation in $P$. falciparum. The process of protein prenylation is a very attractive target for the development of new drugs for cancer and parasites (Docampo \& Moreno 2001; Stresing et al., 2007). One of the most potent bisphosphonates clinically used 
to treat bone resorption diseases, risedronate, inhibited the protein isoprenylation in $P$. falciparum (Jordao et al., 2011). In order to investigate the mechanism of action for risedronate in intraerythrocytic stages of $P$. falciparum, parasites were incubated with or without risedronate and with [1-(n)- $\left.{ }^{3} \mathrm{H}\right] \mathrm{FPP},\left[1-(\mathrm{n})-{ }^{3} \mathrm{H}\right] \mathrm{GGPP}$ and $\left[{ }^{14} \mathrm{C}\right] \mathrm{IPP}$, purified on a Percoll gradient, lysed, and analyzed by TLC and SDS-PAGE. The results showed that protein prenylation is inhibited by decreasing the biosynthesis of farnesyl pyrophosphate and geranylgeranyl pyrophosphate. Additionally, it was demonstrated that risedronate inhibits the transference of $\left[1-(\mathrm{n})-{ }^{3} \mathrm{H}\right] \mathrm{FPP}$ to proteins but not the $\left[1-(\mathrm{n})-{ }^{3} \mathrm{H}\right] \mathrm{GGPP}$ in $P$. falciparum.

\subsection{Protein dolichylation in $P$. falciparum}

Another type of protein modification is the attachment of a dolichyl group to proteins. This type of modification is characterized by covalently and post-translationally bound dolichyl groups to the C-terminal cysteine residues of proteins. Protein dolichylation was described in tumor cells and dolichylated proteins could be involved in the cell cycle control (Hjertman et al., 1997).

Our group has previously shown that P. falciparum synthesizes dolichols of 11 and 12 isoprene units (Couto et al., 1999) and that these compounds can be attached to a group of 21-24 kDa proteins of this parasite (Moura et al., 2001). To confirm the existence of dolichyl groups attached to P. falciparum proteins, D'Alexandri et al. (2006) performed in vitro metabolic labeling of the parasites with [1-(n)-3 $\left.{ }^{3} \mathrm{H}\right] \mathrm{FPP}$ or $\left[1-(\mathrm{n}){ }^{-3} \mathrm{H}\right] \mathrm{GGPP}$. They used these precursors instead of $\left[{ }^{3} \mathrm{H}\right]$ dolichol for analysis of protein dolichylation because commercially available [ $\left.{ }^{3} \mathrm{H}\right]$ dolichol has dolichols of 16 and 21 isoprene units that are longer than those synthesized by $P$. falciparum. After metabolic labeling, the proteins were extracted, extensively delipidated and analyzed by SDS-PAGE. RP-TLC and RP-HPLC analysis of [1-(n)-3 ${ }^{3}$ ]FPP-labeled compounds released from the 21 to $28 \mathrm{kDa}$ from $P$. falciparum proteins revealed that a dolichol of 11 isoprene units and a polyisoprenoid of 12 isoprene units can be attached to proteins of this parasite. The dolichol structure was confirmed by electrospray-ionization mass spectrometry analysis. Treatment with protein synthesis inhibitors and RP-HPLC analysis of the proteolytic digestion products from parasite proteins labeled with [35S]cysteine and [1-(n)-3 $\mathrm{H}] \mathrm{FPP}$ showed that the attachment of dolichol to protein is a post-translational event and probably occurs via a covalent bond to cysteine residues. This was the first demonstration of protein dolichylation in parasites, and also may represent a new potential target for anti-malarial drugs.

\section{Concluding remarks}

The use of radioactive tracers in metabolic labeling in cultures of $P$. falciparum allowed the identification of many steps of the isoprenoid biosynthesis. In figure 3 we summarize the intermediaries' biosynthesizing by the MEP pathway and the isoprenoids identified in $P$. falciparum until the moment. This pathway is different from the human host and we hypothesize that the identification of related enzymes may directly lead to the development of new antimalarial drugs. In many aspects, radiotracers are important, often indispensable tools for the identification of metabolic intermediates not only in Plasmodium but also in many other intracellular protozoa and may ultimately help to point to yet undetected novel drug targets. 


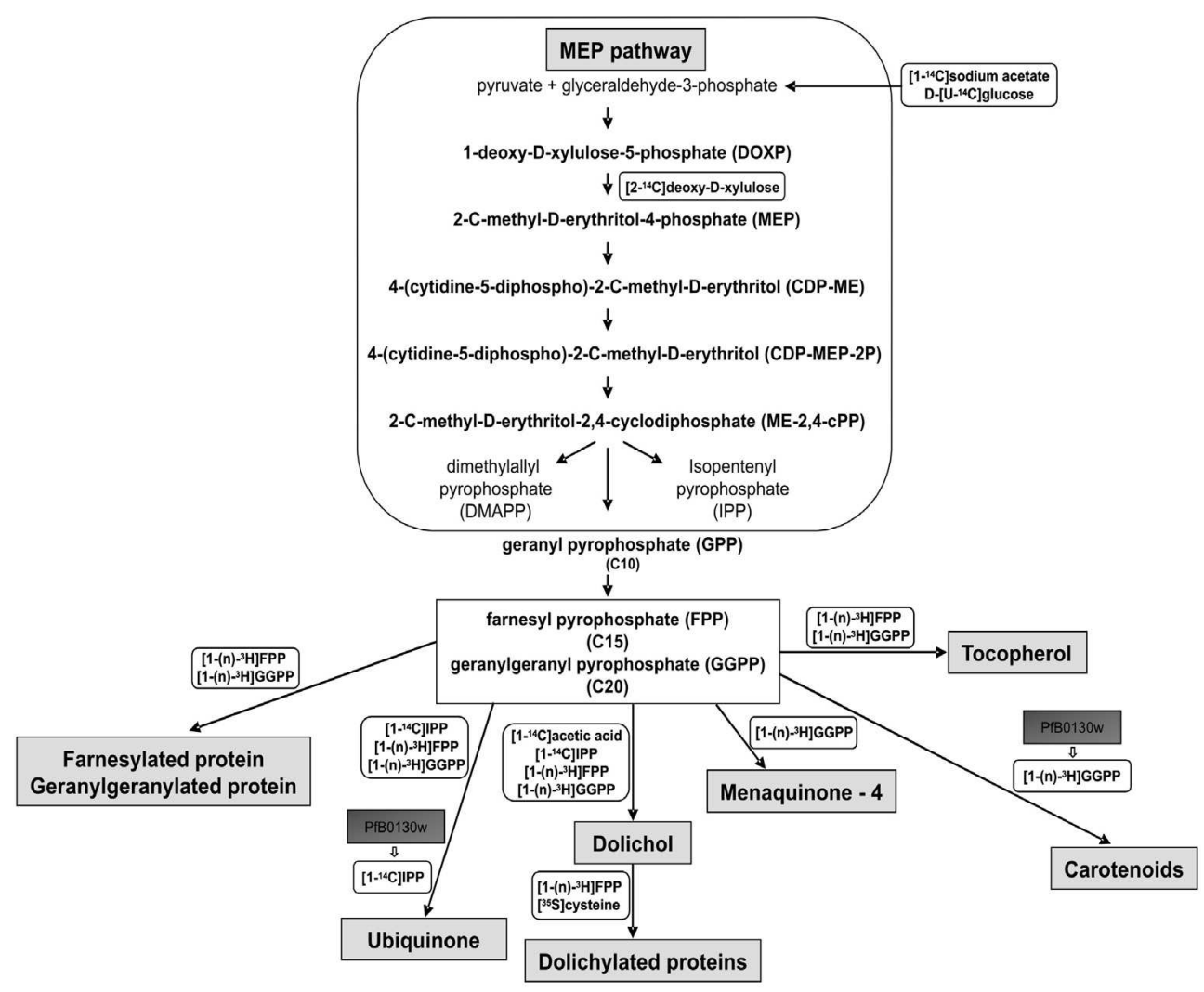

Fig. 3. Isoprenoids biosynthesized by P. falciparum. IPP and DMAPP are biosynthesized by the 2-C-methyl-D-erythritol (MEP)-4-phosphate pathway. Shaded boxes indicate presence the isoprenoids biosynthesized by malaria parasite identified until this moment. White boxes indicate radioactive tracers used for identification of products biosynthesized by $P$. falciparum. PfBO130w correspond to a bi-functional enzyme octaprenyl pyrophosphate synthase/ phytoene synthase that use [1-14C]IPP or [1-(n)-3H]GGPP respectively as substrate. 


\section{Acknowledgments}

This work was supported by grants from Brazilian Agencies CNPq and FAPESP (Brazil). F.M.J. and R.A.C.S. are the recipient of a post-graduate fellowship from CNPq. A.Y.S. and H.B.G. receive post-graduate fellowships from FAPESP. R.T. is the recipient of a postdoctoral fellowship from PNPD/CAPES.

\section{References}

Alexandre, M. A., C. O. Ferreira, et al. (2010). Severe Plasmodium vivax malaria, Brazilian Amazon. Emerg Infect Dis, Vol. 16, No. 10, (Oct 2010), pp. (1611-1614).

Anstey, N. M., B. Russell, et al. (2009). The pathophysiology of vivax malaria. Trends Parasitol, Vol. 25, No. 5, (May 2009), pp. (220-227).

Aurrecoechea, C., J. Brestelli, et al. (2009). PlasmoDB: a functional genomic database for malaria parasites. Nucleic Acids Res, Vol. 37, No. Database issue, (Jan 2009), pp. (D539-543).

Beeson, J. G. and G. V. Brown (2002). Pathogenesis of Plasmodium falciparum malaria: the roles of parasite adhesion and antigenic variation. Cell Mol Life Sci, Vol. 59, No. 2, (Feb 2002), pp. (258-271).

Bozdech, Z., M. Llinas, et al. (2003). The transcriptome of the intraerythrocytic developmental cycle of Plasmodium falciparum. PLoS Biol, Vol. 1, No. 1, (Oct 2003), pp. (E5).

Braun-Breton, C., M. Jendoubi, et al. (1986). In vivo time course of synthesis and processing of major schizont membrane polypeptides in Plasmodium falciparum. Mol Biochem Parasitol, Vol. 20, No. 1, (Jul 1986), pp. (33-43).

Buffet, P. A., I. Safeukui, et al. (2011). The pathogenesis of Plasmodium falciparum malaria in humans: insights from splenic physiology. Blood, Vol. 117, No. 2, (Jan 13 2011), pp. (381-392).

Bushkin, G. G., D. M. Ratner, et al. (2010). Suggestive evidence for Darwinian Selection against asparagine-linked glycans of Plasmodium falciparum and Toxoplasma gondii. Eukaryot Cell, Vol. 9, No. 2, (Feb 2010), pp. (228-241).

Cassera, M. B., F. C. Gozzo, et al. (2004). The methylerythritol phosphate pathway is functionally active in all intraerythrocytic stages of Plasmodium falciparum. J Biol Chem, Vol. 279, No. 50, (Dec 10 2004), pp. (51749-51759).

Chakrabarti, D., T. Da Silva, et al. (2002). Protein farnesyltransferase and protein prenylation in Plasmodium falciparum. J Biol Chem, Vol. 277, No. 44, (Nov 1 2002), pp. (4206642073).

Chaudhuri, R., S. Ahmed, et al. (2008). MalVac: database of malarial vaccine candidates. Malar J, Vol. 7, No. 2008), pp. (184).

Couto, A. S., E. A. Kimura, et al. (1999). Active isoprenoid pathway in the intra-erythrocytic stages of Plasmodium falciparum: presence of dolichols of 11 and 12 isoprene units. Biochem J, Vol. 341 ( Pt 3), No. (Aug 1 1999), pp. (629-637).

Cox-Singh, J. and B. Singh (2008). Knowlesi malaria: newly emergent and of public health importance? Trends Parasitol, Vol. 24, No. 9, (Sep 2008), pp. (406-410). 
D'Alexandri, F. L., E. A. Kimura, et al. (2006). Protein dolichylation in Plasmodium falciparum. FEBS Lett, Vol. 580, No. 27, (Nov 27 2006), pp. (6343-6348).

de Macedo, C. S., M. L. Uhrig, et al. (2002). Characterization of the isoprenoid chain of coenzyme Q in Plasmodium falciparum. FEMS Microbiol Lett, Vol. 207, No. 1, (Jan 22 2002), pp. (13-20).

Dieckmann-Schuppert, A., S. Bender, et al. (1992). Apparent lack of N-glycosylation in the asexual intraerythrocytic stage of Plasmodium falciparum. Eur J Biochem, Vol. 205, No. 2, (Apr 15 1992), pp. (815-825).

Docampo, R. and S. N. Moreno (2001). Bisphosphonates as chemotherapeutic agents against trypanosomatid and apicomplexan parasites. Curr Drug Targets Infect Disord, Vol. 1, No. 1, (May 2001), pp. (51-61).

Dondorp, A. M., F. Nosten, et al. (2009). Artemisinin resistance in Plasmodium falciparum malaria. N Engl J Med, Vol. 361, No. 5, (Jul 30 2009), pp. (455-467).

Eckstein-Ludwig, U., R. J. Webb, et al. (2003). Artemisinins target the SERCA of Plasmodium falciparum. Nature, Vol. 424, No. 6951, (Aug 21 2003), pp. (957-961).

Ekland, E. H. and D. A. Fidock (2008). In vitro evaluations of antimalarial drugs and their relevance to clinical outcomes. Int J Parasitol, Vol. 38, No. 7, (Jun 2008), pp. (743747).

Ekvall, H. (2003). Malaria and anemia. Curr Opin Hematol, Vol. 10, No. 2, (Mar 2003), pp. (108-114).

Ernster, L. and G. Dallner (1995). Biochemical, physiological and medical aspects of ubiquinone function. Biochim Biophys Acta, Vol. 1271, No. 1, (May 24 1995), pp. (195204).

Field, H., I. Blench, et al. (1996). Characterisation of protein isoprenylation in procyclic form Trypanosoma brucei. Mol Biochem Parasitol, Vol. 82, No. 1, (Nov 12 1996), pp. (6780).

Florens, L., M. P. Washburn, et al. (2002). A proteomic view of the Plasmodium falciparum life cycle. Nature, Vol. 419, No. 6906, (Oct 3 2002), pp. (520-526).

Foley, D. A., J. Kennard, et al. (1978). Plasmodium berghei: infective exoerythrocytic schizonts in primary monolayer cultures of rat liver cells. Exp Parasitol, Vol. 46, No. 2, (Dec 1978), pp. (166-178).

Funes, S., E. Davidson, et al. (2002). A green algal apicoplast ancestor. Science, Vol. 298, No. 5601, (Dec 13 2002), pp. (2155).

Gardner, M. J., N. Hall, et al. (2002). Genome sequence of the human malaria parasite Plasmodium falciparum. Nature, Vol. 419, No. 6906, (Oct 3 2002), pp. (498-511).

Good, M. F. (2001). Towards a blood-stage vaccine for malaria: are we following all the leads? Nat Rev Immunol, Vol. 1, No. 2, (Nov 2001), pp. (117-125).

Gowda, D. C., P. Gupta, et al. (1997). Glycosylphosphatidylinositol anchors represent the major carbohydrate modification in proteins of intraerythrocytic stage Plasmodium falciparum. J Biol Chem, Vol. 272, No. 10, (Mar 7 1997), pp. (6428-6439).

Granja, A. C., F. Machungo, et al. (1998). Malaria-related maternal mortality in urban Mozambique. Ann Trop Med Parasitol, Vol. 92, No. 3, (Apr 1998), pp. (257-263). 
Grau, G. E., C. D. Mackenzie, et al. (2003). Platelet accumulation in brain microvessels in fatal pediatric cerebral malaria. J Infect Dis, Vol. 187, No. 3, (Feb 1 2003), pp. (461466).

Guerra, C. A., R. E. Howes, et al. (2010). The international limits and population at risk of Plasmodium vivax transmission in 2009. PLoS Negl Trop Dis, Vol. 4, No. 8, 2010), pp. (e774).

Hayes, C. N., D. Diez, et al. (2008). varDB: a pathogen-specific sequence database of protein families involved in antigenic variation. Bioinformatics, Vol. 24, No. 21, (Nov 1 2008), pp. (2564-2565).

Hemmer, C. J., F. G. Holst, et al. (2006). Stronger host response per parasitized erythrocyte in Plasmodium vivax or ovale than in Plasmodium falciparum malaria. Trop Med Int Health, Vol. 11, No. 6, (Jun 2006), pp. (817-823).

Hjertman, M., J. Wejde, et al. (1997). Evidence for protein dolichylation. FEBS Lett, Vol. 416, No. 3, (Oct 27 1997), pp. (235-238).

Hollingdale, M. R. (1992). Is culture of the entire plasmodium cycle, in vitro, now a reality? Parasitol Today, Vol. 8, No. 7, (Jul 1992), pp. (223).

Huff, C. G. (1964). Cultivation of the Exoerythrocytic Stages of Malarial Parasites. Am J Trop Med Hyg, Vol. 13, No. (Jan 1964), pp. (SUPPL 171-177).

Ibrahim, M., N. Azzouz, et al. (2001). Identification and characterisation of Toxoplasma gondii protein farnesyltransferase. Int J Parasitol, Vol. 31, No. 13, (Nov 2001), pp. (1489-1497).

Jordao, F. M., A. Y. Saito, et al. (2011). In vitro and in vivo antiplasmodial activity of risedronate and its interference with protein prenylation in P. falciparum. Antimicrob Agents Chemother, Vol. 55, No. 5, (May 2011), pp. (2026-2031).

Kimura, E. A., A. S. Couto, et al. (1996). N-linked glycoproteins are related to schizogony of the intraerythrocytic stage in Plasmodium falciparum. J Biol Chem, Vol. 271, No. 24, (Jun 14 1996), pp. (14452-14461).

Lacerda, M. V., M. A. Alexandre, et al. (2004). Idiopathic thrombocytopenic purpura due to vivax malaria in the Brazilian Amazon. Acta Trop, Vol. 90, No. 2, (Apr 2004), pp. (187-190).

Lalloo, D. G., A. J. Trevett, et al. (1996). Severe and complicated falciparum malaria in Melanesian adults in Papua New Guinea. Am J Trop Med Hyg, Vol. 55, No. 2, (Aug 1996), pp. (119-124).

Langreth, S. G. and W. Trager (1973). Fine structure of the malaria parasite Plasmodium lophurae developing extracellularly in vitro. J Protozool, Vol. 20, No. 5, (Nov 1973), pp. (606-613).

Leloir, L. F. (1977). The role of dolichol in protein glycosylation. Adv Exp Med Biol, Vol. 83, No. 1977), pp. (9-19).

Lim, L. and G. I. McFadden (2010). The evolution, metabolism and functions of the apicoplast. Philos Trans R Soc Lond B Biol Sci, Vol. 365, No. 1541, (Mar 12 2010), pp. (749-763).

Lombardo, M., F. C. Pinto, et al. (2006). Isolation and structural characterization of microcystin-LR and three minor oligopeptides simultaneously produced by 
Radiocystis feernandoi (Chroococcales, Cyanobacteriae): a Brazilian toxic cyanobacterium. Toxicon, Vol. 47, No. 5, (Apr 2006), pp. (560-566).

Lujan, H. D., M. R. Mowatt, et al. (1995). Isoprenylation of proteins in the protozoan Giardia lamblia. Mol Biochem Parasitol, Vol. 72, No. 1-2, (Jun 1995), pp. (121-127).

Luo, S., N. Marchesini, et al. (1999). A plant-like vacuolar $\mathrm{H}(+)$-pyrophosphatase in Plasmodium falciparum. FEBS Lett, Vol. 460, No. 2, (Oct 29 1999), pp. (217-220).

Maier, A. G., B. M. Cooke, et al. (2009). Malaria parasite proteins that remodel the host erythrocyte. Nat Rev Microbiol, Vol. 7, No. 5, (May 2009), pp. (341-354).

Marsh, K., D. Forster, et al. (1995). Indicators of life-threatening malaria in African children. N Engl J Med, Vol. 332, No. 21, (May 25 1995), pp. (1399-1404).

McFadden, G. I., M. E. Reith, et al. (1996). Plastid in human parasites. Nature, Vol. 381, No. 6582, (Jun 6 1996), pp. (482).

McTaggart, S. J. (2006). Isoprenylated proteins. Cell Mol Life Sci, Vol. 63, No. 3, (Feb 2006), pp. (255-267).

Menendez, C., A. F. Fleming, et al. (2000). Malaria-related anaemia. Parasitol Today, Vol. 16, No. 11, (Nov 2000), pp. (469-476).

Miller, L. H., M. F. Good, et al. (1994). Malaria pathogenesis. Science, Vol. 264, No. 5167, (Jun 24 1994), pp. (1878-1883).

Millet, P., P. Anderson, et al. (1994). In vitro cultivation of exoerythrocytic stages of the simian malaria parasites Plasmodium fieldi and Plasmodium simiovale in rhesus monkey hepatocytes. J Parasitol, Vol. 80, No. 3, (Jun 1994), pp. (384-388).

Millet, P., T. L. Fisk, et al. (1988). Cultivation of exoerythrocytic stages of Plasmodium cynomolgi, P. knowlesi, P. coatneyi, and P. inui in Macaca mulatta hepatocytes. Am J Trop Med Hyg, Vol. 39, No. 6, (Dec 1988), pp. (529-534).

Mons, B., C. J. Janse, et al. (1983). In vitro culture of Plasmodium berghei using a new suspension system. Int J Parasitol, Vol. 13, No. 2, (Apr 1983), pp. (213-217).

Moore, R. B., M. Obornik, et al. (2008). A photosynthetic alveolate closely related to apicomplexan parasites. Nature, Vol. 451, No. 7181, (Feb 21 2008), pp. (959-963).

Moura, I. C., G. Wunderlich, et al. (2001). Limonene arrests parasite development and inhibits isoprenylation of proteins in Plasmodium falciparum. Antimicrob Agents Chemother, Vol. 45, No. 9, (Sep 2001), pp. (2553-2558).

O'Donovan, S. M. and J. P. Dalton (1993). An improved medium for Plasmodium chabaudi in vitro erythrocyte invasion assays. J Eukaryot Microbiol, Vol. 40, No. 2, (Mar-Apr 1993), pp. (152-154).

Ogura, K. and T. Koyama (1998). Enzymatic Aspects of Isoprenoid Chain Elongation. Chem Rev, Vol. 98, No. 4, (Jun 18 1998), pp. (1263-1276).

Ogura, K., T. Koyama, et al. (1997). Polyprenyl diphosphate synthases. Subcellular Biochemistry: Cholesterol: Its function and Metabolism in Biology and Medicine. R. Bottman. New York, Plenum Press. 28: 57-87.

Rodrigues Goulart, H., E. A. Kimura, et al. (2004). Terpenes arrest parasite development and inhibit biosynthesis of isoprenoids in Plasmodium falciparum. Antimicrob Agents Chemother, Vol. 48, No. 7, (Jul 2004), pp. (2502-2509). 
Rohmer, M., M. Knani, et al. (1993). Isoprenoid biosynthesis in bacteria: a novel pathway for the early steps leading to isopentenyl diphosphate. Biochem J, Vol. 295 ( Pt 2), No. (Oct 15 1993), pp. (517-524).

Sanghai, S. R. and I. Shah (2010). Plasmodium vivax with acute glomerulonephritis in an 8year old. J Vector Borne Dis, Vol. 47, No. 1, (Mar 2010), pp. (65-66).

Schmidt, R. A., C. J. Schneider, et al. (1984). Evidence for post-translational incorporation of a product of mevalonic acid into Swiss 3 T3 cell proteins. J Biol Chem, Vol. 259, No. 16, (Aug 25 1984), pp. (10175-10180).

Schneider, C. (2005). Chemistry and biology of vitamin E. Mol Nutr Food Res, Vol. 49, No. 1, (Jan 2005), pp. (7-30).

Schwarz, R. T. and R. Datema (1982). The lipid pathway of protein glycosylation and its inhibitors: the biological significance of protein-bound carbohydrates. Adv Carbohydr Chem Biochem, Vol. 40, No. 1982), pp. (287-379).

Shen, P. S., J. C. Sanford, et al. (1996). Entamoeba histolytica: isoprenylation of p21ras and p21rap in vitro. Exp Parasitol, Vol. 82, No. 1, (Jan 1996), pp. (65-68).

Siqueira, A. M., M. A. Alexandre, et al. (2010). Severe rhabdomyolysis caused by Plasmodium vivax malaria in the Brazilian Amazon. Am J Trop Med Hyg, Vol. 83, No. 2, (Aug 2010), pp. (271-273).

Stresing, V., F. Daubine, et al. (2007). Bisphosphonates in cancer therapy. Cancer Lett, Vol. 257, No. 1, (Nov 8 2007), pp. (16-35).

Sussmann, R. A. C. (2010). Vitamin E Biosynthesis in intraerythrocytic stages of Plasmodium falciparum. Parasitology Department. São Paulo, University of São Paulo. Master Thesis 76.

Tonhosolo, R., F. L. D'Alexandri, et al. (2009). Carotenoid biosynthesis in intraerythrocytic stages of Plasmodium falciparum. J Biol Chem, Vol. 284, No. 15, (Apr 10 2009), pp. (9974-9985).

Tonhosolo, R., F. L. D'Alexandri, et al. (2005). Identification, molecular cloning and functional characterization of an octaprenyl pyrophosphate synthase in intraerythrocytic stages of Plasmodium falciparum. Biochem J, Vol. 392, No. Pt 1, (Nov 15 2005), pp. (117-126).

Tonhosolo, R., H. B. Gabriel, et al. (2010). Intraerythrocytic stages of Plasmodium falciparum biosynthesize menaquinone. FEBS Lett, Vol. 584, No. 23, (Dec 1 2010), pp. (47614768).

Trager, W. and J. B. Jensen (1976). Human malaria parasites in continuous culture. Science, Vol. 193, No. 4254, (Aug 20 1976), pp. (673-675).

Trager, W. and J. B. Jensen (1997). Continuous culture of Plasmodium falciparum: its impact on malaria research. Int J Parasitol, Vol. 27, No. 9, (Sep 1997), pp. (989-1006).

Valderramos, S. G., D. Scanfeld, et al. (2010). Investigations into the role of the Plasmodium falciparum SERCA (PfATP6) L263E mutation in artemisinin action and resistance. Antimicrob Agents Chemother, Vol. 54, No. 9, (Sep 2010), pp. (3842-3852).

Watkins, B. and C. Sibley (2011). Vivax malaria: old drug, new uses? J Infect Dis, Vol. 203, No. 2, (Jan 15 2011), pp. (144-145).

WHO (2010a). Guidelines for the treatment of malaria. Switzerland, World Health Organization: 194. 
WHO (2010b). World Malaria Report. Switzerland, World Health Organization: 238.

Zhang, F. L. and P. J. Casey (1996). Protein prenylation: molecular mechanisms and functional consequences. Annu Rev Biochem, Vol. 65, No. 1996), pp. (241-269). 


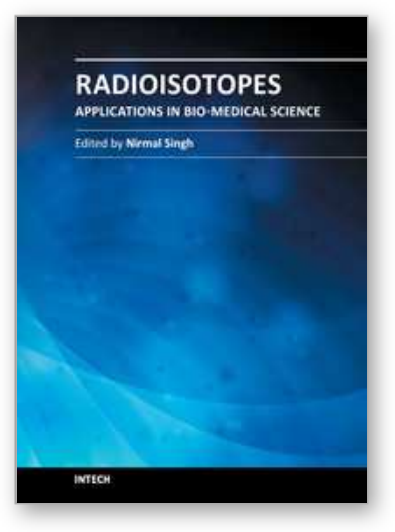

\author{
Radioisotopes - Applications in Bio-Medical Science \\ Edited by Prof. Nirmal Singh
}

ISBN 978-953-307-748-2

Hard cover, 320 pages

Publisher InTech

Published online 21, November, 2011

Published in print edition November, 2011

The book Radioisotopes - Applications in Bio-Medical Science contains two sections: Radioisotopes and Radiations in Bioscience and Radioisotopes and Radiology in Medical Science. Section I includes chapters on medical radioisotope production, radio-labeled nano-particles, radioisotopes and nano-medicine, use of radiations in insects, drug research, medical radioisotopes and use of radioisotopes in interdisciplinary fields etc. In Section II, chapters related to production of metal PET (positron emission tomography) radioisotopes, 3-dimensional and CT (computed tomography) scan, SS nuclear medicine in imaging, cancer diagnose and treatments have been included. The subject matter will by highly useful to the medical and paramedical staff in hospitals, as well as researchers and scholars in the field of nuclear medicine medical physics and nuclear biochemistry etc.

\title{
How to reference
}

In order to correctly reference this scholarly work, feel free to copy and paste the following:

Emilia A. Kimura, Gerhard Wunderlich, Fabiana M. Jordão, Renata Tonhosolo, Heloisa B. Gabriel, Rodrigo A. C. Sussmann, Alexandre Y. Saito and Alejandro M. Katzin (2011). Use of Radioactive Precursors for Biochemical Characterization the Biosynthesis of Isoprenoids in Intraerythrocytic Stages of Plasmodium falciparum, Radioisotopes - Applications in Bio-Medical Science, Prof. Nirmal Singh (Ed.), ISBN: 978-953-307748-2, InTech, Available from: http://www.intechopen.com/books/radioisotopes-applications-in-bio-medicalscience/use-of-radioactive-precursors-for-biochemical-characterization-the-biosynthesis-of-isoprenoids-in-in

\section{INTECH}

open science | open minds

\section{InTech Europe}

University Campus STeP Ri

Slavka Krautzeka 83/A

51000 Rijeka, Croatia

Phone: +385 (51) 770447

Fax: +385 (51) 686166

www.intechopen.com

\section{InTech China}

Unit 405, Office Block, Hotel Equatorial Shanghai

No.65, Yan An Road (West), Shanghai, 200040, China

中国上海市延安西路65号上海国际贵都大饭店办公楼405单元

Phone: +86-21-62489820

Fax: $+86-21-62489821$ 
APÊNDICE E - Isoprenoid biosynthesis in the erythrocytic stages of Plasmodium falciparum 


\title{
ISOPRENOID BIOSYNTHESIS IN THE ERYTHROCYTIC STAGES OF PLASMODIUM FALCIPARUM
}

\author{
Fabiana Morandi Jordão, Rodrigo A.C. Sussmann, Gehard \\ Wunderlich, Heloisa B. Gabriel, Alexandre Y. Saito Emília A. \\ Kimura, and Alejandro M. Katzin. \\ Department of Parasitology, Institute of Biomedical Sciences, University of São Paulo, \\ São Paulo, Brazil
}

\begin{abstract}
Malaria, a major tropical disease caused by protozoa of the genus Plasmodium, causes the death of approximately 1 million individuals, mostly children, every year. Plasmodium falciparum, the most virulent of the four species that infect humans, is associated with a potentially fatal form of this disease. Due to the crescent resistance of $P$. falciparum to virtually all drugs actually in use the identification of new potential targets for rational drug development is imperative. This task requires a thorough knowledge of the biochemistry of $P$. falciparum.

The apicoplast organelle, which is essential for parasite survival, represents the remnants of the chloroplast. In the case of malaria parasites, especially its most virulent species $P$. falciparum, a series of new "plant-like" enzymes associated with this organelle were recently discovered. The shikimate pathway and methylerythritol phosphate pathway (MEP) are localized in this organelle of P. falciparum. The MEP pathway is the first step for biosynthesis of isoprenoids.

The identification of two genes encoding the enzymes 1-deoxy-D-xylulose-5phosphate synthase and 1-deoxy-D-xylulose-5-phosphate reductoisomerase suggested that isoprenoid biosynthesis in P. falciparum depends on the MEP pathway. In contrast, in humans, isoprenoids are synthesized via the mevalonate pathway. In P. falciparum all the metabolic pathways and associated enzymes downstream of isopentenyl pyrophosphate (IPP) need to be identified and characterized.

In this chapter we described the biosynthesis of MEP pathway, several intermediated and final product of isoprenoids pathway in the intraerythrocytic stages of $P$. falciparum. These products like a dolichol, ubiquinone, menaquinone and carotenoids are related to different physiological functions in the parasites. We will discuss the possibility to
\end{abstract}


evaluate some drugs used currently against other disease as potential anti-malarial activity.

\section{INTRODUTION}

Malaria affects 300-500 million people and causes the death of approximately 1 million individuals per year, mostly children under 5 years old and pregnant women. This parasite is becoming resistant to most drugs currently used in the treatment of disease. Malaria drug resistance is not the same as malarial treatment failure, which is the inability to clear malarial parasitemia and/or resolve clinical symptoms. While drug resistance may lead to treatment failure, not all treatment failures are caused by drug resistance. Treatment failure can also be the result of incorrect dosage, problems of treatment adherence, poor drug quality, interactions with other drugs, compromised drug absorption or misdiagnosis of the patient [1].

The emergence of resistance is due to widespread and indiscriminate use of antimalarials. This exerts a strong selective pressure on malaria parasites to develop high levels of resistance. On the other hand, the spread of resistance is due to the existence of the sexual cycle of the parasite in the invertebrate host where there is genetic exchange. Efforts to solve this problem are based on combined therapies with drugs that have not presented resistance and to identify new drug targets [2].

The phylum Apicomplexa, specifically hemosporidians, piroplasms (both groups are blood parasites, including Plasmodium) and coccidians (for example, Toxoplasma gondii and the veterinary pathogen Eimeria) possess an apicoplast, which was acquired millions of years ago during an evolutionary event [3]. An ancestor of the phylum Apicomplexa gained a plastid by secondary endosymbiosis of a photosynthetic eukaryote [4]. The chloroplast of this organism was retained and during evolution, many chloroplastid genes were transferred to the apicomplexan nucleus while others were lost [5-6]. In the case of the malaria parasite, especially the most virulent species, $P$. falciparum, a series of new "plantlike" enzymes was recently discovered and some of these enzymes are associated with the apicoplast [7], whereas the nature of the others and the pathways they are involved in remain elusive to current bioinformatics approaches.

The plant and algae plastids are the site for many essential biochemical pathways; some of them were already found in P. falciparum. The apicoplasts retained some biosynthetic pathways such as isoprenoid biosynthesis and fatty acids. The enzymes of these pathways are encoded in the nucleus and present signal peptide that indicate their location in the apicoplasts [8]. It was shown that the shikimate [9-10] and methylerythritol phosphate (MEP) [11-12] pathways are active in the parasite. It is possible that other metabolic routes were retained and incorporated in the parasite metabolism [13].

Despite these hurdles, the field of malaria research has witnessed some extremely notable developments in the recent past including sequencing of the malaria genome [14] the application of proteomics to study the malaria life cycle [15], the malaria transcriptome [16] and several web resources such as Mal-Vac (database of malaria vaccine candidates), PlasmoDB (genome database of the Plasmodium genus) and VarDB (database for antigenic variation gene families) [17-19]. A thorough knowledge of the biochemistry of $P$. falciparum is required in order to develop new drugs. This aim can be achieved by two means: either by 
focusing on validated targets in order to generate new drug candidates; or by identifying new potential targets for malaria chemotherapy. In the last decade, our group has characterized some products from the MEP pathway and identified a number of enzyme candidates as new drug targets. Because animals do not possess plastids, the apicoplast represents an opportunity to target these parasites with treatments that are relatively harmless to mammalian hosts [20].

In this chapter we describe the biosynthesis of MEP pathway, several intermediate and final products of the isoprenoid pathway in the intraerythrocytic stages of $P$. falciparum. These products like dolichol, ubiquinone, menaquinone and carotenoids are related to different physiological functions in the parasites such as the biosynthesis of $N$-linked glycoproteins, the electron transport chain and antioxidant mechanisms respectively. Several enzymes related to this metabolic pathway could be targets of antimalarial drugs since the isoprenoids are absent or are different in humans.

\section{ISOPRENOIDS}

Isoprene is a five-carbon hydrocarbon with a branched-chain structure, two double bonds, and the molecular formula $\mathrm{C}_{5} \mathrm{H}_{8}$. In isoprenoids, isoprene units are linked into larger molecules having from few to many five-carbon units that can take the form of both linear structures and rings. Many of these molecules play a wide variety of roles in plant and animal physiological processes and also as intermediates in the synthesis of other biologically important molecules. They contribute much to the flavor and fragrance of essential oils and other herbal substances. Isoprenoids include several molecules such as sterols, dolichol, plastoquinone, ubiquinone, carotenoids, and prenyl side chains of chlorophylls. However, despite its structural and functional diversity, all isoprenoids are derived from a common precursor, the isopentenyl pyrophosphate (IPP) and its isomer, dimethylallyl pyrophosphate (DMAPP). Two distinct and independent pathways biosynthesize IPP: the classical mevalonate pathway (MVA) and a mevalonate-independent or methylerythritol phosphate (MEP) pathway.

\subsection{Mevalonate Pathway}

The elucidation of the biosynthesis of IPP and DMAPP were the results of the first applications of metabolic labeling using radioactive markers but also stable isotopes, which ultimately led to the discovery of the MVA pathway in the 50's [21]. MVA is an important metabolic pathway that provides cells with essential bioactive molecules, vital in multiple cellular processes [22]. This pathway for the biosynthesis of isoprenoids from acetate represents the initial step in a series of enzymatic reactions that have, for decades, been established to account for production of polyisoprenoids (e.g. dolichol) and sterols (e.g. lanosterol, ergosterol, cholesterol) in fungi, plant cytoplasm, animals, most other eukaryotes, archaea and some eubacteria [23]. These intermediates of the mevalonate biosynthetic pathway play important roles in the post-translational modification of a multitude of proteins involved in intracellular signaling, in cell growth/differentiation, gene expression, protein 
glycosylation and cytoskeletal assembly, photosynthesis, respiration, hormonal regulation of metabolism, defense against pathogen attack, vesicular transport within the cell, membrane structure and as coenzymes [22, 24].

The first steps of isoprenoid biosynthesis have been characterized primarily in vitro, in 1958 in cell-free homogenates from rat liver and yeast [24]. The mevalonate-isoprenoid pathway involves first the synthesis of 3-hydroxy-3-methylglutaryl-CoA (HMG)-CoA from acetyl-CoA through acetoacetyl-CoA, the 3-hydroxy-3-methylglutaryl-CoA reductase (HMGR), one of the most highly regulated enzymes in nature, catalyzes the conversion of HMG-CoA to mevalonic acid [22, 25]. Mevalonate is then doubly phosphorylated by two kinases (MvaK1, MvaK2), decarboxylated, and dehydrated (MvaD) to form IPP [25]. Some molecules of IPP are then converted into DMAPP by the enzyme IPP isomerase (Figure 1).

Despite contradicting previous statements that the mevalonate pathway present in bacteria occurred by horizontal gene transfer (HGT), recent studies concluded that the MVA pathway is likely an ancestral metabolic route in all the three domains of life and were probably present in the last common ancestor of all organisms [26].

\subsection{The Methylerythritol Phosphate (MEP) Pathway}

The MEP pathway was first described in eubacteria [27] and afterwards in several photosynthetic organisms such as higher plants [28] and algae [29] and cyanobacteria [30]. Later, it was described in apicomplexan parasites [12] and Mycobacterium tuberculosis [31]. It was also found in several pathogenic eubacteria, but not in animals and archaebacteria [32]. The MEP pathway consists of eight reactions catalyzed by nine different enzymes in bacteria.

The initial step is the formation of 1-deoxy-D-xylulose-5-phosphate (DOXP) by the condensation of pyruvate and glyceraldehyde-3-phosphate, catalyzed by DOXP synthase. The $d x p$ gene encoding this enzyme was first cloned from E. coli [33]. This key enzyme of the pathway requires thiamine pyrophosphate and divalent cations such as $\mathrm{Mg}^{2+}$ or $\mathrm{Mn}^{2+}$ for its activity. The following enzyme DOXP reductoisomerase catalyzes the rearrangement and subsequent reduction of DOXP to 2-C-methyl-D-erythritol-4-phosphate (MEP). The activity of this enzyme is inhibited by fosmidomycin [34]. The next step is the ispD gene product 4(cytidine-5-diphospho)-2-C-methyl-D-erythritol synthase-driven conversion of MEP to 4(cytidine-5-diphospho)-2-C-methyl-D-erythritol (CDP-ME). CDP-ME is then converted to CDP-MEP-2-P by the enzyme 4-(cytidine-5-diphospho)-2-C-methyl-D-erythritol kinase. CDP-MEP-2-P is then converted to 2- $C$-methyl-D-erythritol-2,4-cyclodiphosphate (ME-2,4cPP) by the action of 2-C-methyl-D-erythritol 2,4-cyclodiphosphate synthase. IPP and DMAPP are synthesized through independent routes in the last steps of the MEP pathway [32] (Figure 1). Additionally, the MEP pathway produces the precursor (DOXP) for the synthesis of the essential cofactors thiamin diphosphate and pyridoxal phosphate [35]. 


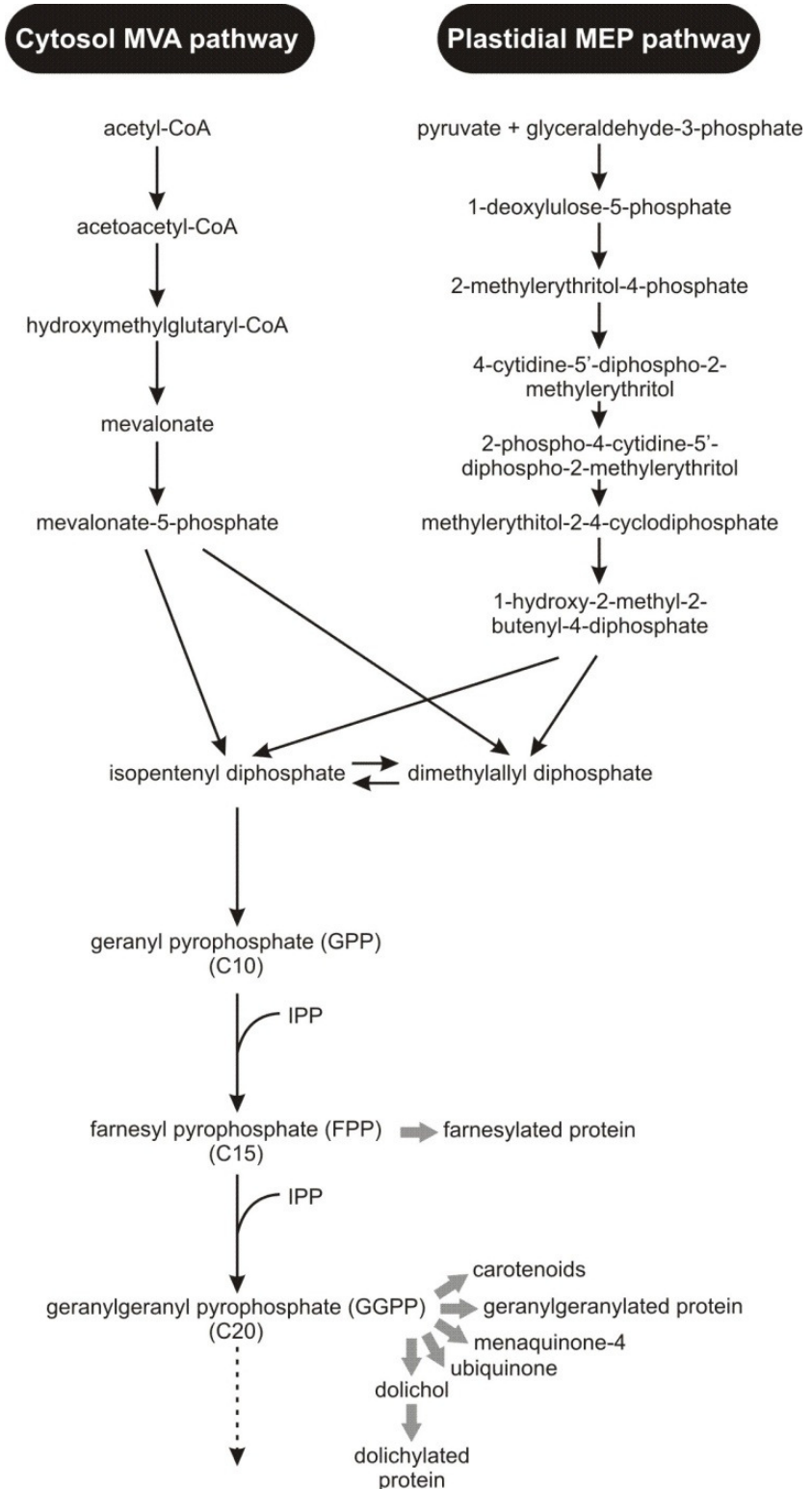

Figure 1. Biosynthetic pathways of IPP and DMAPP, the universal precursors of isoprenoids: The shaded arrows indicate the isoprenic compounds currently characterized in P. falciparum by our group.

Characterization of this pathway is one of the best examples of modern proteomics research, driven by a combination of genomic data and biological chemistry. Researchers have exploited NMR methodology to track and map out substrates and products, enzymeassisted synthesis to acquire reagents necessary to characterize pathway components and crystallography to provide structural detail that complements detailed enzymatic studies [20]. 


\section{METHODOLOGY FOR CHARACTERIZATION OF THE ISOPRENOID PATHWAY IN P. FALCIPARUM}

One of the strategies to identify each product of a metabolic pathway is metabolic labeling using a radioactive precursor and a posterior analysis by an appropriate method. Several final products biosynthesized by isoprenoids pathway were identified in intraerythrocytic stages of $P$. falciparum using radiotracers such as $\left[{ }^{3} \mathrm{H}\right] \mathrm{GGPP},\left[{ }^{3} \mathrm{H}\right] \mathrm{FPP}$ and $\left[{ }^{14} \mathrm{C}\right] \mathrm{IPP}$. Labeling of parasites with their precursor identified ubiquinones of 7-8 isoprenic units, dolichol of 11 and 12 isoprenic units, seven carotenes and menaquinone. Using high performance liquid chromatography (HPLC) and thin layer chromatography (TLC) techniques, some of these compounds were structurally characterized via biochemical and electrospray mass spectrometric analyses. Isoprenylated proteins could be identified by SDSPAGE. Expression of recombinant octaprenyl pyrophosphate synthase and phytoene synthase led to their characterization and some kinetics parameters could be determined using the radioactive substrates $\left[{ }^{14} \mathrm{C}\right] \mathrm{IPP}$ or $\left[{ }^{3} \mathrm{H}\right] \mathrm{GGPP}$ respectively.

The characterization of the isoprenic compounds in P. falciparum clone 3D7 was cultured according to the protocol described by Trager and Jensen [36] where human sera was substituted for Albumax I (0.5\%). Parasites were grown in a tissue culture flask $\left(75 \mathrm{~cm}^{2}\right)$ with $40 \mathrm{ml}$ volume under mixture atmosphere of $5 \% \mathrm{CO}_{2}, 5 \% \mathrm{O}_{2}$, and $90 \% \mathrm{~N}_{2}$. While asynchronous cultures yielded mixed ring, trophozoite and schizont stages, synchronous cultures beginning in ring stage were obtained after two treatments with $5 \%(\mathrm{w} / \mathrm{v}) \mathrm{D}$-sorbitol solution in water. The subsequent maintenance in culture led to synchronous trophozoite (20$30 \mathrm{~h}$ after reinvasion) or schizont (30-35h after reinvasion) stages. Parasite development and multiplication were monitored by microscopic evaluation of Giemsa stained thin smears. Cultures of $P$. falciparum with a parasitemia of approximately $10 \%$ were labeled with the different precursors in normal RPMI-1640 medium for $15 \mathrm{~h}$ after which each stage was purified. The asynchronous parasites were purified on a 40/70/80 percent discontinuous Percoll $^{\circledR}$ gradient [37]. The culture was centrifuged at $600 \mathrm{~g}$ for $5 \mathrm{~min}$ at room temperature, the pellet resuspended in RPMI-1640 (1:1 v/v) and carefully placed on top of the gradient. The tubes were centrifuged at $10,000 \mathrm{x}$ g for $20 \mathrm{~min}$ at $20^{\circ} \mathrm{C}$. The cells containing schizonts, trophozoite and ring stages, respectively, were collected, washed twice in RPMI-1640, the pellet of parasites was stored in liquid $\mathrm{N}_{2}$ for subsequent analysis. Synchronous cultures with predominantly schizont stages were purified with magnetic column separation (MACS Separation Columns "CS"). The pre-equilibration, washing, and elution of the column were all performed at room temperature with RPMI-1640. The culture was centrifuged, the pellet resuspended in RMPI-1640 $(1: 10 \mathrm{v} / \mathrm{v}), 10 \mathrm{ml}$ of the $10 \%$ suspension of erythrocytes were applied to a CS column assembled in a magnetic unit to remove non-infected erythrocytes, ring-infected erythrocytes and young trophozoites. The column was washed by filling with 50 $\mathrm{ml}$ of RMPI-1640 and removed from the magnetic field and its contents were eluted with 50 $\mathrm{ml}$ of RMPI-1640. The resulting schizonts were centrifuged at $600 \mathrm{~g}$ for $5 \mathrm{~min}$ at room temperature, and the pellet was stored in liquid $\mathrm{N}_{2}$ for subsequent analysis. Parasitic forms were monitored by microscopic evaluation of Giemsa-stained thin smears. We specifically focused on i) MEP pathway which leads to the isoprenoids IPP/DMAPP and ii) downstream reactions which result in dolichol, ubiquinone, menaquinone, carotenoids and other related compounds. 


\section{Mevalonate-Independent Methylerythritol Phosphate (MEP) PATHWAY IN P. FAlCiPARUM}

Various attempts to provide evidence for the existence of the MVA pathway in Plasmodium sp. had to ambiguous results. In order to characterize the presence of this pathway, $\left[{ }^{3} \mathrm{H}\right]$-mevalonolactone or $(\mathrm{RS})-\left[5-{ }^{3} \mathrm{H}\right]$-mevalonate is commonly used to perform the labeling [38]. Unfortunately, all efforts to label isoprenoid constituents with these precursors in $P$. falciparum were unsuccessful. Labeling of in vitro cultures of $P$. falciparum parasites using $\left[{ }^{3} \mathrm{H}\right]$-mevalonolactone was conducted to analyze dolichols and ubiquinones but no products were identified (Katzin and colleagues, unpublished data). Inhibitors (lovastatin and simvastatin) of HMG-CoA reductase, interfered with the in vitro development of $P$. falciparum, but only at high, pharmacologically irrelevant concentrations [39]. Accordingly, no HMG-CoA reductase activity was detectable above background levels in extracts from $P$. falciparum and $P$. knowlesi [40]. Mbaya et al., 1990, identified characterized farnesyl pyrophosphate upon incubation of extracts from $P$. falciparum infected red blood cells with $\left[{ }^{14} \mathrm{C}\right]$-mevalonate [41].

Jomaa et al., 1999, showed for the first time that isoprenoid biosynthesis in P. falciparum depended on the MEP pathway. They identified the presence of two genes encoding the enzymes DOXP synthase and DOXP reductoisomerase and described the enzymatic activity of recombinant $P$. falciparum DOXP reductoisomerase by conversion of DOXP to MEP. This conversion could be inhibited by fosmidomycin. These authors also elucidated showed that an amino-terminal signal sequence in DOXP reductoisomerase targeted the enzyme to the apicoplast [12]. In addition, DOXP reductoisomerase activity could be detected in crude and partially purified protein extracts from $P$. falciparum using a sensitive functional assay [42]. Recently, Umeda et al., 2010, obtained the crystal of DOXP reductoisomerase from $P$. falciparum and preliminary X-ray crystallographic and structural analyses by molecular replacement are in progress [43]. Rohdich et al., 2001, characterized the recombinant enzyme 2-C-methyl-D-erythritol 2,4-cyclodiphosphate synthase in $P$. falciparum [44]. Finally, Ralph et al., 2004, suggested the presence of several MEP pathway related genes in P. falciparum, all of which possess apicoplast-targeting sequences, indicating that the DOXP pathway is localized in the apicoplast [45]. Recently, Hunter et al., 2011, revised the different stages of the MEP pathway in some organisms including P. falciparum [46]. So far, all genes related to the MEP pathway were identified in the $P$. falciparum genome but only three genes that encode the enzymes DOXP synthase, DOXP reductoisomerase, and 2- $C$-methyl-D-erythritol2,4-cyclodiphosphate synthase were functionally characterized.

Biochemically, Cassera et al., 2004, showed by metabolic labeling with $\left[1-{ }^{14} \mathrm{C}\right]$ acetate, $\mathrm{D}$-[U $\left.-{ }^{14} \mathrm{C}\right]$ glucose and $\left[2-{ }^{14} \mathrm{C}\right] \mathrm{DOXP}$ that the MEP pathway is functionally active in intraerythrocytic stages of $P$. falciparum. The group identified all but one of the intermediates of the MEP pathway using HPLC and mass spectrometric analyses. The identified intermediates were 1-deoxy-D-xylulose-5- phosphate, 2- $C$-methyl-D-erythritol-4-phosphate, 4-(cytidine-5-diphospho)-2- $C$-methyl-D-erythritol, 4-(cytidine-5-diphospho)-2- $C$-methyl-Derythritol-2-phosphate and 2- $C$-methyl-D-erythritol-2,4-cyclodiphosphate [11].

Clastre et al., 2007, demonstrated that the MEP pathway was also active in other apicomplexan parasites, namely Eimeria tenella and T. gondii. Additionally, transcription profiles confirmed that MEP pathway related genes were transcribed in these parasites. 
Intriguingly, BLAST analysis showed that Cryptosporidium parvum and C. hominis lack both the MVA and MEP pathways, however, these species contained orthologs of prenyltransferases, suggesting that isoprenoid precursors perhaps may be acquired from the host [47].

The presence of the MEP pathway in a large number of pathogenic organisms, including bacteria, fungi, and apicomplexan parasites, and their absence from mammals make them an attractive target for the development of antimicrobial agents. Each enzyme in the pathway provides a potential target [9].

\subsection{Fosmidomycin}

Fosmidomycin was shown to inhibit the DOXP reductoisomerase from bacteria and plants [48]. Jomaa et al., 1999, demonstrated that fosmidomycin and its derivate FR-900098 are both able to inhibit the growth of $P$. falciparum in culture and suppressed the in vitro growth of multidrug-resistant $P$. falciparum strains. Moreover, mice infected with the rodent malaria parasite Plasmodium vinckei were cured after treatment with fosmidomycin. FR900098, a fosmidomycin derivative, was found to be twice as effective [12].

In former studies with volunteers and patients suffering from bacterial infections, fosmidomycin was well tolerated [49]. Clinical studies showed that fosmidomycin was effective in the treatment of patients with acute uncomplicated $P$. falciparum malaria but unfortunately resulted in an unacceptably high rate of recrudescence [50]. Field trials in humans have also demonstrated the effectiveness of fosmidomycin in the treatment of human malarial infections [51-52].

Cassera et al., 2004, identified the intermediates of the MEP pathway and analyzed the effect of fosmidomycin on levels of the MEP pathway intermediates and showed that the effect was most prominent in ring stages and only minor inhibitory effects were observed in trophozoite and schizont stages, reflecting differences in the drug-sensitivity of the parasite blood forms. They also showed that the MEP pathway provides precursors for the synthesis of ubiquinone and dolichol. This fact was demonstrated by the decrease in the ubiquinone and dolichol content in fosmidomycin-treated parasites [11]. Since fosmidomycin inhibits the DOXP reductoisomerase and kills malaria parasites, biosynthesis of isoprenoids have been presumed to be essential in Plasmodium. Interestingly, similar to effects observed for the inhibition of plasmodial dihydrofolate reductase [53], no alteration in the transcription of MEP pathway related genes was found [54]. There is no feedback control of transcription exerted by metabolites of the MEP pathway as often found in other organisms. Surprisingly, fosmidomycin had only a small effect on the growth of either $T$. gondii or $E$. tenella in vitro, even at higher concentrations, suggesting that the drug is either not as active or its uptake is inefficient in these apicomplexan parasites [47].

Recently, it was demonstrated that fosmidomycin directly inhibits its known target, DOXP reductoisomerase, and indirectly acts upon cells to inhibit a second target, the downstream enzyme methylerythritol phosphate cytidyltransferase (IspD) [55]. 


\section{BIOSYNTHESIS OF ISOPRENOIDS IN P. FALCIPARUM}

\subsection{Characterization of Dolichol in $P$. falciparum}

Several glycoconjugates, biosynthesized by the intraerythrocytic stages of $P$. falciparum, use dolichol and its phosphorylated derivatives as carrier lipids. Anchors and $\mathrm{N}$-linked glycoproteins require dolichyl phosphate and dolichyl pyrophosphate as carriers of different mono-saccharide constituents [56]. Kimura et al., 1996, demonstrated the effect of N-linked glycoproteins on differentiation of intraerythrocytic stages of $P$. falciparum [57]. Walter, 1986, demonstrated the presence of dolichol kinase, a rate-limiting enzyme for the supply of dolichyl pyrophosphate, in P. falciparum [58]. Many eukaryotic cells, such as yeast and a number of mammalian cells, are unable to incorporate more complex isoprenoid precursors such as $\left[{ }^{3} \mathrm{H}\right] \mathrm{FPP}$ and $\left[{ }^{3} \mathrm{H}\right] \mathrm{GGPP}$. In contrast, intraerythrocytic forms of $P$. falciparum easily metabolize these compounds when they are added to the culture medium, permitting the subsequent identification of higher isoprenoids. Accordingly, Couto et al., 1999, identified dolichol, dolichyl phosphate and dolichyl pyrophosphate of 55-60 carbons (11/12 isoprenic units) by metabolic labeling of parasites with $\left[{ }^{3} \mathrm{H}\right] \mathrm{FPP}$ and $\left[{ }^{3} \mathrm{H}\right] \mathrm{GGPP}$ in different intraerythrocytic stages of $P$. falciparum. This study was the first demonstration of shortchain dolichols in the phylum Apicomplexa [59]. Despite the fact that few reports exist on the characterization of dolichols in protozoan, the presence of short-chain isoprenoid species seems to be a common feature. Dolichols of 13 isoprene units in Trypanosoma cruzi [60], 11 isoprene units in Crithidia fasciculata [61] and 11-12 isoprene units in Trypanosoma brucei [62] have been reported.

The biosynthetic pathways for cholesterol, dolichol and ubiquinones share the same initial steps. Using [1-14C] acetate and ${ }^{3} \mathrm{H}_{2} \mathrm{O}$ as labeling precursors, Vial et al., 1984, showed that cholesterol synthesis in $P$. falciparum was almost undetectable, in accordance with very low levels of measurable HMG-CoA reductase activity [40].

\subsection{Ubiquinone Biosynthesis}

Isoprenoid quinones are composed of a polar head group and a hydrophobic side chain [63-64]. The apolar isoprenoid side chain gives the molecule a lipid-soluble character and anchors them in membrane lipid bilayers, whereas the hydrophilic head group enables interaction with hydrophilic parts of proteins. Long chain, isoprenoid quinones localized in the hydrophobic mid-plane region of the lipid bilayer, whereas the polar head can oscillate between mid-plane and the polar interphase of the membrane. The quinone ring derives from the shikimate pathway, a metabolic pathway present in algae, higher plants, bacteria and fungi, is also present in apicomplexan parasites. This pathway's final products are the aromatic amino acids: phenylalanine, tyrosine and tryptophan, as well as the intermediate chorismate. These amino acids are central molecules in plant metabolism and are also essential compounds in the diets of humans and monogastric livestock, which are unable to synthesize them [63]. In P. falciparum the shikimate pathway was discovered as part of the biosynthesis of folates $p$-Aminobenzoate (PABA) is an intermediate in the pathway, which is essential for the production of folic acid and necessary for parasite survival. PABA, reversing 
the toxic effect caused by the herbicide glyphosate [ $N$-(phosphonomethyl) glycine], an inhibitor of the enzyme 5-enolpyruvyl-shikimate-3-phosphate synthase (EPSP synthase) which catalyzes the penultimate step of the shikimate pathway [9, 65-67].

This quinone ring can undergo a two-step reversible reduction leading to the quinol form. The reduced form of isoprenoid quinones is more polar and the quinol head group is thought to preferentially localize at the polar inter-phase region of membranes. The great majority of biological isoprenoid quinones belong to naphthoquinones or benzoquinones. The two most important groups of benzoquinones are ubiquinones and plastoquinones, which differ in the pattern of ring substitution [68].

Coenzyme $\mathrm{Q}(\mathrm{CoQ})$ is a molecule composed of a benzoquinone ring with a side chain made of several isoprenic units, whose number determines the identity of coenzyme Q [69]. It is present in every membrane of all cells in the body. Under normal physiological conditions all cells biosynthesize functionally sufficient amounts of this lipid. It was shown to be a necessary component of the mitochondrial respiratory chain and functions as an electron carrier from complex I and II to complex III. Besides acting in many other functions in mitochondrial respiration and oxidative phosphorylation, it has a well-characterized antioxidant role [70].

CoQ inhibits lipid peroxidation by preventing the production of lipid peroxyl radicals (LOO) and, moreover, $\mathrm{CoQH}_{2}$ reduces the initial perferryl radical, with concomitant formation of ubisemiquinone and $\mathrm{H}_{2} \mathrm{O}_{2}$. This quenching of the initial perferryl radicals, which prevent propagation of lipid peroxidation, protects not only lipids, but also proteins from oxidation. In addition, the reduced form of $\mathrm{CoQ}$ effectively regenerates vitamin $\mathrm{E}$ from the $\alpha$ tocopheroxyl radical [70].

Ubiquinones (UQs) are found only in $\alpha$ - $\beta$ - and $\gamma$ - proteobacteria are also present in eukaryotic organisms, which supports with the theory of endosymbiosis, according to which proteobacteria were ancestors of mitochondria [68]. A polyprenyl diphosphate synthase is involved in the elongation of the side chain. This isoprenic chain is then attached to $p$ hydroxybenzoic acid (PHBA), which is synthesized via the shikimic acid pathway in apicomplexan parasites [69].

The number of isoprenoid units in the prenyl side chain often varies among species [68]. Some organisms contain ubiquinones with different side chain lengths that are synthesized by specific prenyltransferases. For example, the size of the ubiquinone side chain is C30 in Saccharomyces cerevisiae, C45 in rats and C50 in humans. These are synthesized by hexaprenyl pyrophosphate synthase, solanesyl pyrophosphate synthase and decaprenyl pyrophosphate synthase respectively $[68,71]$, while in $E$. coli the octaprenyl pyrophosphate synthase (OPPs) enzyme is responsible for the biosynthesis of side chains attached to ubiquinones. OPPs belongs to a prenyltransferase family that catalyses the condensation reactions of FPP with five molecules of IPP to produce C40 (octaprenyl pyrophosphate) [71].

Coenzyme Q8 and coenzyme Q9 were identified in P. falciparum by labeling of parasites with $\left[1-{ }^{14} \mathrm{C}\right]$ acetic acid, $\left[{ }^{14} \mathrm{C}\right] \mathrm{IPP},\left[{ }^{3} \mathrm{H}\right] \mathrm{FPP}$, and $\left[{ }^{3} \mathrm{H}\right] \mathrm{GGPP}$ in all intraerythrocytic stages. The parasite is capable of synthesizing two different homolog of coenzyme $\mathrm{Q}$, depending on the given radioactive intermediate. When labeling is performed with $\left[{ }^{3} \mathrm{H}\right] \mathrm{FPP}$, coenzyme $\mathrm{Q}$ with an isoprenic chain of 40 carbons (Q8) is detected; while $\left[{ }^{3} \mathrm{H}\right]$ GGPP labeling results in Q9 (45 carbons) [69]. This difference in the length of the isoprenic chain according to the given precursor was also observed in P. falciparum dolichols [59, 69]. Also, an OPPs activity and its inhibition by the terpene nerolidol was demonstrated in P. falciparum [71]. 


\subsection{Carotenoids Biosynthesis}

Carotenoids are widespread lipophilic pigments synthesized by all photosynthetic organisms and some nonphotosynthetic fungi and bacteria. All carotenoids are derived from the isoprenoid biosynthesis pathway and possess a polyisoprenoid structure, a long conjugated chain of double bonds, and an almost bilateral symmetry around the central double bond. Their biosynthesis starts with the condensation of two molecules of GGPP to form phytoene, the initial C40 carotenoid skeleton. Different carotenoids are derived essentially by modifications in the base structure such as cyclization of the end groups and by introduction of oxygen functions, resulting in their characteristic colors and antioxidant properties.

Given the existence of plant-like pathways such as the synthesis of carotenoids in apicomplexa, it can be postulated that other herbicides will also be effective against the growth of parasites such as T. gondii and Plasmodium. An example is toltrazuril, an herbicide belonging to the class of triazines. Its activity is probably the result of the interaction of the herbicide with the D1 protein of the photosynthetic reaction center [72]. Dinitroaniline herbicides (oryzalin, trifluralin and ethalfluralin) are specific inhibitors of the synthesis of microtubules in plants and inhibited the multiplication of $T$. gondii in a dose-dependent concentration. All dinitroaniline herbicides specifically inhibited the cytokinesis of parasites in submicromolar concentrations without affecting the host cells [73].

The carotenoids biosynthesized by the intraerythrocytic stages of $P$. falciparum were shown by metabolic labeling with the direct precursor $\left[{ }^{3} \mathrm{H}\right] \mathrm{GGPP}$ and identified by two HPLC methods and confirmed by ESI-MS/MS and LC-APCI-MS/MS analyses. Neither of these compounds were detected in uninfected erythrocytes or in RPMI culture medium and subsequent tests in $P$. falciparum extracts showed that the parasite possesses the machinery to synthesize carotenoids [74].

Parasites of $P$. falciparum were treated with norflurazon, a well known bleaching herbicide that inhibits carotenoid biosynthesis in higher plants and microalgae by competitive inhibition of the phytoene desaturase [75]. There was an inhibition of carotenoid biosynthesis, accumulation of phytoene and a growth inhibition of parasites in vitro culture. Likewise, the growth inhibition could be partially reverted by the addition of lycopene, which is readily taken up, thus providing the products of the norflurazon-inhibited step in the carotenoid pathway [74].

In silico analyses suggested the presence of a candidate for phytoene synthesis [74]. Intriguingly, the candidate gene encoding the enzyme phytoene synthase that synthesizes the first product of the carotenoid biosynthesis, phytoene, was previously characterized by our group as an octaprenyl pyrophosphate synthase [71]. This plasmodial enzyme is a rare example of a carotenogenic enzyme with a continuous line of evolution from archaea to bacteria (via cyanobacteria) and plants [76-77] containing two activities.

\subsection{Menaquinone Biosynthesis}

Vitamin $\mathrm{K}$, in vertebrates, is an important factor that promotes the $\gamma$-carboxylation of factors involved in coagulation, among others. Vitamin $\mathrm{K}$ compounds are derived from 2 methyl-1,4-naphthoquinones. The basic structure is a ring naphthoquinone from the shikimate 
pathway, methylated in position 2 and a side chain, from the MEP pathway, located in position 3. In plants and cyanobacteria the shikimate and MEP pathways are the precursors for biosynthesis of phylloquinone (PK) while bacteria biosynthesize menaquinone (MK) [7879].

The isoprenoid side chain of menaquinones is most frequently composed of 6-10 prenyl units but also homologues with one to 14 prenyl units were found in some species. The side chain is most often fully unsaturated, but it can be also partially or fully saturated in some organisms. The length and degree of saturation of the side chain are often dependent on the growth temperature of a given species [68].

Menaquinones are the most widespread microbial respiratory quinones that are the oldest evolutionarily conserved isoprenoids. These compounds can be found in many groups of Archaea and bacteria, such as $\gamma$ - $\delta$ - $\varepsilon$-proteobacteria, gram-positive bacteria, green sulfur bacteria, green filamentous bacteria, deinococci and flavobacteria. It has a low midpoint redox potential and their presence in early phases of the evolution can be associated with the reducing character of the atmosphere before the appearance of oxygenic photosynthesis and the following increase in the oxygen concentration in the environment [68].

Vitamin $\mathrm{K}$ is synthesized from chorismate, where six subsequent reactions enzyme reactions lead to the formation of the naphthoquinone ring, or 1,4 dihydroxy-2-naftoil-CoA. The enzymes engaged in DHNA biosynthesis are: MenF-isochorismate synthase, MenD- 2succinyl-6-hydroxy-2,4-cyclohexadiene-1-carboxylate synthase, MenH- SHCHC synthase, MenC- o-succinyl benzoate synthase, MenE- osuccinylbenzoic acid-CoA synthase, MenB1,4-dihydroxy-2- naphthoyl-CoA synthase and DHNA-CoA thioesterase [68]. The reaction is condensed by a DHNA prenyltransferase. After condensation, the naphthoate group is modified by methylation [78-79].

The number of prenyl units in the attached isoprenoid side chain is determined by the length of isoprenoid diphosphate and may differ among species (e.g. E. coli-mainly MK-8, Bacillus firmus- MK-7, Geobacter metallireducens- MK-8, P. falciparum- MK-4) [68, 80].

Through labeling with the direct precursor $\left[{ }^{3} \mathrm{H}\right] \mathrm{GGPP}$ it was shown that intraerythrocytic stages of $P$. falciparum synthesize menaquinone (MK-4) and this was achieved via the identification by five different chromatographic methods reported for this type of molecule and confirmation by ESI-MS/MS analysis [80]. MK in P. falciparum could replace the physiological function of ubiquinone as an electron acceptor in the respiratory chain under anaerobic conditions. Many respiratory enzymes from E. coli can use both menaquinone and ubiquinone as a substrate depending on the oxygen supply in the environment, while mammals have only ubiquinone. During its intraerythrocytic development in the human host, the malaria parasite $P$. falciparum is subjected to considerable changes in the oxygen concentration due to intermittent cytoadherence in the deep vasculature and [80] $P$. falciparum can change the content of the quinine pools depending on the aeration condition. Additionally, it was shown that the mycobacterial inhibitor of menaquinone synthesis RO 488071 also suppressed MK biosynthesis and growth of $P$. falciparum parasites.

RO 48-8071 \{[4'-(6-allyl-ethyl-amino-hexyloxy)-2'-fluoro-phenyl]-(4-bromophenyl)methanone $\}$ is a potent inhibitor of 2,3-oxidosqualene: lanosterol cyclase (OSC, E.C. 5.4.99.7). This compound is being investigated as a possible cholesterol-lowering drug. It affects blood plasma by reducing the synthesis of lanosterol and subsequent sterol, and also stimulates the production of epoxysterols that repress HMG-CoA reductase expression, generating a synergistic, self-limited negative regulatory loop [81]. 
This drug is being further investigated as a possible anti-malarial drug. Tonhosolo et. al., 2010, identified the biosynthesis of menaquinone during intra-erythrocytic P. falciparum growth by using RO 48-8071 to inhibit the menaquinone biosynthesis. The apparent was an inhibition of menaquinone synthesis resulted in the reduced parasite growth at an $\mathrm{IC}_{50}$ of 4.5 $\mu \mathrm{M}$ [80]. The mechanism is not well understood, however, it is believed that this drug is inhibiting the 1,4-dihydroxy-2-naphthoate prenyltransferase (MenA) as occurs in bacteria, thereby inhibiting the menaquinone biosynthesis [82].

\section{Post-Translational Modification in P. FalCiparum}

\subsection{Protein Farnesylation and Geranylgeranylation in P. falciparum}

A large number of post-translational modifications take place in the cell such as phosphorylation, methylation, acetylation, glycosylation and lipid modifications, many of which regulate several biological activities. The lipid modifications, which are found in all eukaryotic cells, fall into three major classes and are characterized by the type of lipid and the site of modification in the protein. They include myristoylation, palmitoylation and prenylation of proteins.

Protein prenylation involves the attachment of the two types of isoprenoids: 15-carbon farnesyl pyrophosphate (FPP) and 20-carbon geranylgeranyl pyrophosphate (GGPP), respectively [83]. The reaction is catalyzed by three types of protein prenyltransferases that attach farnesyl or geranylgeranyl, respectively, to conserved C-terminal cysteines of a small subset of cellular proteins. Protein prenylation and three distinct heterodimeric protein prenyltransferases have been described in metazoan, protozoan, fungi and plants.

Protein farnesyltransferase (PFT) transfers a farnesyl group from farnesyl diphosphate to the cysteine residue of a carboxyl terminal CaaX motif (where ' $\mathrm{C}$ ' is cysteine, ' $\mathrm{a}$ ' is an aliphatic amino acid, and ' $\mathrm{X}$ ' is usually methionine, glutamine, serine, alanine, or cysteine). Protein geranylgeranyltransferase type I (PGGT I) usually transfers a geranylgeranyl group from geranylgeranyl diphosphate to the cysteine residue of a similar CaaX motif (where ' $\mathrm{X}$ ' is leucine or isoleucine). Protein geranylgeranyl-transferase type II (PGGT II, also called $\mathrm{RAB}$ geranylgeranyltransferase) transfers two geranylgeranyl groups from GGPP to the cysteine residues of XCCXX, XXCXC, XXCCX, XXXCC, XCXXX, or CCXXX motifs at the carboxyl terminus of RAB proteins bound to the RAB Escort Protein (REP) [84-85].

The post-translational modification of proteins by the addition of isoprenoids has been recognized as a key physiological process for facilitating cellular protein-protein interactions and membrane-associated protein trafficking. This type of post-translational modification creates a hydrophobic tail that facilitates membrane association as well as protein-protein interactions. Among known prenylated proteins are small GTPases, including Ras, Rac, Rho, and Rab, which play a role in cell signal transduction, vesicle trafficking, and cell cycle progression [86].

Post-translational modification of proteins with isoprenoids was first recognized as a general phenomenon in 1984 [86]. Though numerous prenylated proteins have been identified, these are likely to represent only a small proportion of the $0.5-2 \%$ of mammalian proteins that are estimated to contain farnesyl or geranylgeranyl groups. Protein prenylation is 
a general phenomenon in eukaryotic cells and has been described for several parasites including P. falciparum [87], Trypanosoma brucei [88], Trypanosoma cruzi [89], Leishmania species [89], Toxoplasma gondii [90], Giardia lamblia [91] and Entamoeba histolytica [92].

The first indication that protein prenylation is functional in $P$. falciparum was demonstrated by Chakrabarti et al., 1998, when they reported the identification of protein farnesyl transferase (PFT) and protein geranylgeranyl transferase-I activities from fractionated lysates in all intraerythrocytic stages of P. falciparum [93]. Later, families of Rab G-protein and Ras-related proteins were characterized in P. falciparum [94-95].

Chakrabarti et al., 2002, demonstrated by metabolic radiolabeling with $\left[{ }^{3} \mathrm{H}\right]$ farnesol and $\left[{ }^{3} \mathrm{H}\right]$ geranylgeraniol that a $50-\mathrm{kDa}$ protein is farnesylated, whereas $22-28-\mathrm{kDa}$ proteins are geranylgeranylated. Furthermore, they showed that peptidomimetics and prenyl analogues could inhibit PFT purified from parasites and also inhibited malaria parasite growth [87]. Ohkanda et al., 2001, demonstrated the potency of a variety of other peptidomimetics as inhibitors of $P$. falciparum growth and PfPFT activity [97].

Our group characterized proteins with isoprenic groups by labeling with $\left[{ }^{3} \mathrm{H}\right] \mathrm{FPP}$ and $\left[{ }^{3} \mathrm{H}\right] \mathrm{GGPP}$ and also showed that treatment of parasites with the monoterpene limonene inhibited parasite growth by decreasing the progress from ring to trophozoite stages and also decreased the incorporation of isoprenic groups in proteins [96].

Later, Rodrigues Goulart et al., 2004, demonstrated that terpenes (farnesol, nerolidol, limonene and linalool) and S-farnesylthiosalicylic acid (FTS) led to a decrease in the amount of isoprenylated proteins in P. falciparum schizont stages [97]. AbouLaila et al., 2010, showed that there was inhibition of growth in vitro of four species of Babesia in the presence of nerolidol. In addition, mice infected with B. microti and treated with $100 \mathrm{mg} / \mathrm{kg}$ of nerolidol had significant reduction in parasitemia compared to controls [98].

Recently, Singh et al., 2010, studied the effect of a new generation of bisphosphonate lipophilic blocking prenylation of proteins and showed a potent activity against $P$. berghei liver stage in vivo. Mice treated with a bisphosphonate called BPH-715 and infected with sporozoites of $P$. berghei showed complete protection without the appearance of the erythrocytic stage after 28 days of observation. However, this lipophilic bisphosphonate had a mild inhibitory effect against the erythrocytic stage [99].

Corroborating these results Jordão et al., 2011, demonstrated that the bisphosphonate risedronate inhibited the transfer of the farnesyl pyrophosphate group to parasite proteins decreasing parasite growth in vitro in cultures of $P$. falciparum. In vivo risedronate led to an $88.9 \%$ inhibition of the rodent parasite $P$. berghei in Balb/c mice on the seventh day of treatment; however, no general increase of survival rates was achieved [100].

\subsection{Protein Dolichylation in $P$. falciparum}

Another type of protein modification is the attachment of a dolichyl group to proteins. This type of modification is characterized by covalently and post-translationally bound dolichyl groups to the $\mathrm{C}$-terminal cysteine residues of proteins. The protein dolichylation was described in tumor cells and dolichylated proteins are possibly involved in cell cycle control [101]. In $P$. falciparum dolichylated proteins with 11 isoprenic units were found attached to 21 and $28 \mathrm{kDa}$ sized proteins. The purpose of dolichylation of proteins in P. falciparum is currently unknown, and one may speculate involvement in cell cycle control as in tumor cells 
[101] since the dolichylated protein species appear predominantly during the replication phase of the parasite (schizogony) [102].

\section{CONCLUSION}

This chapter has provided an insight into the various efforts to characterize the isoprenoids derived from the MEP pathway in P. falciparum. Since the MEP pathway also occurs in several pathogenic bacteria, such as M. tuberculosis, all inhibitors and potential drugs may be used against pathogenic bacteria and the malaria parasite. Because the MEP pathway is not found in humans, the enzymes involved in isoprenoid biosynthesis make this pathway an ideal target for antibacterial and antimalarial. There are still many unanswered questions. For example, we do not know yet the role of carotenoids in the parasite and its cellular and metabolic processes. It is also unclear why the parasite synthesizes many vitamins despite being theoretically able to ingest from them host. Hopefully, future efforts will provide us with potentially new drug targets against this devastating disease.

\section{ACKNOWLEDGMENTS}

This work was supported by grants from Brazilian Agencies CNPq and FAPESP (Brazil). F.M.J. and R.A.C.S. are the recipient of a post-graduate fellowship from CNPq. A.Y.S. and H.B.G. receive post-graduate fellowships from FAPESP. The authors would like to tank Krishna C. Motheramgari for critical reading of manuscript.

\section{REFERENCES}

[1] WHO. World Malaria Report. Switzerland: World Health Organization, 2010.

[2] WHO. Guidelines for the treatment of malaria. Switzerland: World Health Organization, 2010.

[3] Lim L, McFadden GI. The evolution, metabolism and functions of the apicoplast. Philos Trans R Soc Lond B Biol Sci. 2010 Mar 12;365(1541):749-63.

[4] McFadden GI, Reith ME, Munholland J, Lang-Unnasch N. Plastid in human parasites. Nature. 1996 Jun 6;381(6582):482.

[5] Funes S, Davidson E, Reyes-Prieto A, Magallon S, Herion P, King MP, et al. A green algal apicoplast ancestor. Science. 2002 Dec 13;298(5601):2155.

[6] Moore RB, Obornik M, Janouskovec J, Chrudimsky T, Vancova M, Green DH, et al. A photosynthetic alveolate closely related to apicomplexan parasites. Nature. $2008 \mathrm{Feb}$ 21;451(7181):959-63.

[7] Luo S, Marchesini N, Moreno SN, Docampo R. A plant-like vacuolar H(+)pyrophosphatase in Plasmodium falciparum. FEBS Lett. 1999 Oct 29;460(2):217-20.

[8] Wilson RJ. Progress with parasite plastids. J Mol Biol. 2002 May 31;319(2):257-74. 
[9] Roberts CW, Roberts F, Lyons RE, Kirisits MJ, Mui EJ, Finnerty J, et al. The shikimate pathway and its branches in apicomplexan parasites. J Infect Dis. 2002 Feb 15;185 Suppl 1:S25-36.

[10] Roberts F, Roberts CW, Johnson JJ, Kyle DE, Krell T, Coggins JR, et al. Evidence for the shikimate pathway in apicomplexan parasites. Nature. 1998 Jun 25;393(6687):8015 .

[11] Cassera MB, Gozzo FC, D'Alexandri FL, Merino EF, del Portillo HA, Peres VJ, et al. The methylerythritol phosphate pathway is functionally active in all intraerythrocytic stages of Plasmodium falciparum. J Biol Chem. 2004 Dec 10;279(50):51749-59.

[12] Jomaa H, Wiesner J, Sanderbrand S, Altincicek B, Weidemeyer C, Hintz M, et al. Inhibitors of the nonmevalonate pathway of isoprenoid biosynthesis as antimalarial drugs. Science. 1999 Sep 3;285(5433):1573-6.

[13] Tonkin CJ, Kalanon M, McFadden GI. Protein targeting to the malaria parasite plastid. Traffic. 2008 Feb;9(2):166-75.

[14] Gardner MJ, Hall N, Fung E, White O, Berriman M, Hyman RW, et al. Genome sequence of the human malaria parasite Plasmodium falciparum. Nature. 2002 Oct 3;419(6906):498-511.

[15] Florens L, Washburn MP, Raine JD, Anthony RM, Grainger M, Haynes JD, et al. A proteomic view of the Plasmodium falciparum life cycle. Nature. 2002 Oct 3;419(6906):520-6.

[16] Bozdech Z, Llinas M, Pulliam BL, Wong ED, Zhu J, DeRisi JL. The transcriptome of the intraerythrocytic developmental cycle of Plasmodium falciparum. PLoS Biol. 2003 Oct;1(1):E5.

[17] Chaudhuri R, Ahmed S, Ansari FA, Singh HV, Ramachandran S. MalVac: database of malarial vaccine candidates. Malar J. 2008;7:184.

[18] Hayes CN, Diez D, Joannin N, Honda W, Kanehisa M, Wahlgren M, et al. varDB: a pathogen-specific sequence database of protein families involved in antigenic variation. Bioinformatics. 2008 Nov 1;24(21):2564-5.

[19] Aurrecoechea C, Brestelli J, Brunk BP, Dommer J, Fischer S, Gajria B, et al. PlasmoDB: a functional genomic database for malaria parasites. Nucleic Acids Res. 2009 Jan;37(Database issue):D539-43.

[20] Eisenreich W, Bacher A, Arigoni D, Rohdich F. Biosynthesis of isoprenoids via the non-mevalonate pathway. Cell Mol Life Sci. 2004 Jun;61(12):1401-26.

[21] Spurgeon SL, Porter JW. Biosynthesis of Isoprenoid Compounds. Wiley, New York1981.

[22] Buhaescu I, Izzedine H. Mevalonate pathway: a review of clinical and therapeutical implications. Clin Biochem. 2007 Jun;40(9-10):575-84.

[23] Miziorko HM. Enzymes of the mevalonate pathway of isoprenoid biosynthesis. Arch Biochem Biophys. 2011 Jan 15;505(2):131-43.

[24] Wanke M, Skorupinska-Tudek K, Swiezewska E. Isoprenoid biosynthesis via 1-deoxyD-xylulose 5-phosphate/2-C-methyl-D-erythritol 4-phosphate (DOXP/MEP) pathway. Acta Biochim Pol. 2001;48(3):663-72.

[25] Ferrand S, Tao J, Shen X, McGuire D, Schmid A, Glickman JF, et al. Screening for Mevalonate Biosynthetic Pathway Inhibitors Using Sensitized Bacterial Strains. J Biomol Screen. 2011 May 18. 
[26] Lombard J, Moreira D. Origins and early evolution of the mevalonate pathway of isoprenoid biosynthesis in the three domains of life. Mol Biol Evol. 2011 Jan;28(1):8799.

[27] Rohmer M, Knani M, Simonin P, Sutter B, Sahm H. Isoprenoid biosynthesis in bacteria: a novel pathway for the early steps leading to isopentenyl diphosphate. Biochem J. 1993 Oct 15;295 ( Pt 2):517-24.

[28] Rohmer M. The discovery of a mevalonate-independent pathway for isoprenoid biosynthesis in bacteria, algae and higher plants. Nat Prod Rep. 1999 Oct;16(5):565-74.

[29] Disch A, Schwender J, Muller C, Lichtenthaler HK, Rohmer M. Distribution of the mevalonate and glyceraldehyde phosphate/pyruvate pathways for isoprenoid biosynthesis in unicellular algae and the cyanobacterium Synechocystis PCC 6714. Biochem J. 1998 Jul 15;333 ( Pt 2):381-8.

[30] Cvejic JH, Rohmer M. CO2 as main carbon source for isoprenoid biosynthesis via the mevalonate-independent methylerythritol 4-phosphate route in the marine diatoms Phaeodactylum tricornutum and Nitzschia ovalis. Phytochemistry. 2000 Jan;53(1):21-8.

[31] Bailey AM, Mahapatra S, Brennan PJ, Crick DC. Identification, cloning, purification, and enzymatic characterization of Mycobacterium tuberculosis 1-deoxy-D-xylulose 5phosphate synthase. Glycobiology. 2002 Dec;12(12):813-20.

[32] Lichtenthaler HK. Non-mevalonate isoprenoid biosynthesis: enzymes, genes and inhibitors. Biochem Soc Trans. 2000 Dec;28(6):785-9.

[33] Lois LM, Campos N, Putra SR, Danielsen K, Rohmer M, Boronat A. Cloning and characterization of a gene from Escherichia coli encoding a transketolase-like enzyme that catalyzes the synthesis of D-1-deoxyxylulose 5-phosphate, a common precursor for isoprenoid, thiamin, and pyridoxol biosynthesis. Proc Natl Acad Sci U S A. 1998 Mar 3;95(5):2105-10.

[34] Kuzuyama T, Shimizu T, Takahashi S, Seto H. Fosmidomycin, a specific inhibitor of 1deoxy-D-xylulose-5-phosphate reductoisomerase in the nonmevalonate pathway for terpenoid biosynthesis. Tetrahedron Lett. 1998;39(43):7913-6.

[35] Sprenger GA, Schorken U, Wiegert T, Grolle S, de Graaf AA, Taylor SV, et al. Identification of a thiamin-dependent synthase in Escherichia coli required for the formation of the 1-deoxy-D-xylulose 5-phosphate precursor to isoprenoids, thiamin, and pyridoxol. Proc Natl Acad Sci U S A. 1997 Nov 25;94(24):12857-62.

[36] Trager W, Jensen JB. Continuous culture of Plasmodium falciparum: its impact on malaria research. Int J Parasitol. 1997 Sep;27(9):989-1006.

[37] Braun-Breton C, Jendoubi M, Brunet E, Perrin L, Scaife J, Pereira da Silva L. In vivo time course of synthesis and processing of major schizont membrane polypeptides in Plasmodium falciparum. Mol Biochem Parasitol. 1986 Jul;20(1):33-43.

[38] Goldstein JL, Brown MS. Regulation of the mevalonate pathway. Nature. 1990 Feb 1;343(6257):425-30.

[39] Grellier P, Valentin A, Millerioux V, Schrevel J, Rigomier D. 3-Hydroxy-3methylglutaryl coenzyme A reductase inhibitors lovastatin and simvastatin inhibit in vitro development of Plasmodium falciparum and Babesia divergens in human erythrocytes. Antimicrob Agents Chemother. 1994 May;38(5):1144-8.

[40] Vial HJ, Philippot JR, Wallach DF. A reevaluation of the status of cholesterol in erythrocytes infected by Plasmodium knowlesi and P. falciparum. Mol Biochem Parasitol. 1984 Sep;13(1):53-65. 
[41] Mbaya B, Rigomier D, Edorh GG, Karst F, Schrevel J. Isoprenoid metabolism in Plasmodium falciparum during the intraerythrocytic phase of malaria. Biochem Biophys Res Commun. 1990 Dec 31;173(3):849-54.

[42] Wiesner J, Hintz M, Altincicek B, Sanderbrand S, Weidemeyer C, Beck E, et al. Plasmodium falciparum: detection of the deoxyxylulose 5-phosphate reductoisomerase activity. Exp Parasitol. 2000 Nov;96(3):182-6.

[43] Umeda T, Tanaka N, Kusakabe Y, Nakanishi M, Kitade Y, Nakamura KT. Crystallization and preliminary X-ray crystallographic study of 1-deoxy-D-xylulose 5phosphate reductoisomerase from Plasmodium falciparum. Acta Crystallogr Sect F Struct Biol Cryst Commun. 2010 Mar 1;66(Pt 3):330-2.

[44] Rohdich F, Eisenreich W, Wungsintaweekul J, Hecht S, Schuhr CA, Bacher A. Biosynthesis of terpenoids. 2C-Methyl-D-erythritol 2,4-cyclodiphosphate synthase (IspF) from Plasmodium falciparum. Eur J Biochem. 2001 Jun;268(11):3190-7.

[45] Ralph SA, van Dooren GG, Waller RF, Crawford MJ, Fraunholz MJ, Foth BJ, et al. Tropical infectious diseases: metabolic maps and functions of the Plasmodium falciparum apicoplast. Nat Rev Microbiol. 2004 Mar;2(3):203-16.

[46] Hunter WN. Isoprenoid Precursor Biosynthesis Offers Potential Targets for Drug Discovery Against Diseases Caused by Apicomplexan Parasites. Curr Top Med Chem. 2011 May 26.

[47] Clastre M, Goubard A, Prel A, Mincheva Z, Viaud-Massuart MC, Bout D, et al. The methylerythritol phosphate pathway for isoprenoid biosynthesis in coccidia: presence and sensitivity to fosmidomycin. Exp Parasitol. 2007 Aug;116(4):375-84.

[48] Schwender J, Muller C, Zeidler J, Lichtenthaler HK. Cloning and heterologous expression of a cDNA encoding 1-deoxy-D-xylulose-5-phosphate reductoisomerase of Arabidopsis thaliana. FEBS Lett. 1999 Jul 16;455(1-2):140-4.

[49] Kuemmerle HP, Murakawa T, De Santis F. Pharmacokinetic evaluation of fosmidomycin, a new phosphonic acid antibiotic. Chemioterapia. 1987 Apr;6(2):113-9.

[50] Wiesner J, Henschker D, Hutchinson DB, Beck E, Jomaa H. In vitro and in vivo synergy of fosmidomycin, a novel antimalarial drug, with clindamycin. Antimicrob Agents Chemother. 2002 Sep;46(9):2889-94.

[51] Borrmann S, Adegnika AA, Moussavou F, Oyakhirome S, Esser G, Matsiegui PB, et al. Short-course regimens of artesunate-fosmidomycin in treatment of uncomplicated Plasmodium falciparum malaria. Antimicrob Agents Chemother. 2005 Sep;49(9):374954.

[52] Borrmann S, Lundgren I, Oyakhirome S, Impouma B, Matsiegui PB, Adegnika AA, et al. Fosmidomycin plus clindamycin for treatment of pediatric patients aged 1 to 14 years with Plasmodium falciparum malaria. Antimicrob Agents Chemother. 2006 Aug;50(8):2713-8.

[53] Zhang K, Rathod PK. Divergent regulation of dihydrofolate reductase between malaria parasite and human host. Science. 2002 Apr 19;296(5567):545-7.

[54] Cassera MB, Merino EF, Peres VJ, Kimura EA, Wunderlich G, Katzin AM. Effect of fosmidomycin on metabolic and transcript profiles of the methylerythritol phosphate pathway in Plasmodium falciparum. Mem Inst Oswaldo Cruz. 2007 Jun;102(3):377-83.

[55] Zhang B, Watts KM, Hodge D, Kemp LM, Hunstad DA, Hicks LM, et al. A second target of the antimalarial and antibacterial agent fosmidomycin revealed by cellular metabolic profiling. Biochemistry. 2011 Mar 25. 
[56] Schwarz RT, Datema R. The lipid pathway of protein glycosylation and its inhibitors: the biological significance of protein-bound carbohydrates. Adv Carbohydr Chem Biochem. 1982;40:287-379.

[57] Kimura EA, Couto AS, Peres VJ, Casal OL, Katzin AM. N-linked glycoproteins are related to schizogony of the intraerythrocytic stage in Plasmodium falciparum. J Biol Chem. 1996 Jun 14;271(24):14452-61.

[58] Walter RD. Plasmodium falciparum: inhibition of dolichol kinase by mefloquine. Exp Parasitol. 1986 Dec;62(3):356-61.

[59] Couto AS, Kimura EA, Peres VJ, Uhrig ML, Katzin AM. Active isoprenoid pathway in the intra-erythrocytic stages of Plasmodium falciparum: presence of dolichols of 11 and 12 isoprene units. Biochem J. 1999 Aug 1;341 ( Pt 3):629-37.

[60] Parodi AJ, Quesada-Allue LA. Protein glycosylation in Trypanosoma cruzi. I. Characterization of dolichol-bound monosaccharides and oligosaccharides synthesized "in vivo". J Biol Chem. 1982 Jul 10;257(13):7637-40.

[61] Quesada-Allue LA, Parodi AJ. Novel mannose carrier in the trypanosomatid Crithidia fasciculata behaving as a short alpha-saturated polyprenyl phosphate. Biochem J. 1983 Apr 15;212(1):123-8.

[62] Low P, Dallner G, Mayor S, Cohen S, Chait BT, Menon AK. The mevalonate pathway in the bloodstream form of Trypanosoma brucei. Identification of dolichols containing 11 and 12 isoprene residues. J Biol Chem. 1991 Oct 15;266(29):19250-7.

[63] Tzin V, Galili G. New insights into the shikimate and aromatic amino acids biosynthesis pathways in plants. Mol Plant. 2010 Nov;3(6):956-72.

[64] Herrmann KM, Weaver LM. The Shikimate Pathway. Annu Rev Plant Physiol Plant Mol Biol. 1999 Jun;50:473-503.

[65] Haghani K, Salmanian AH, Ranjbar B, Zakikhan-Alang K, Khajeh K. Comparative studies of wild type Escherichia coli 5-enolpyruvylshikimate 3-phosphate synthase with three glyphosate-insensitive mutated forms: activity, stability and structural characterization. Biochim Biophys Acta. 2008 Sep;1784(9):1167-75.

[66] McConkey GA. Targeting the shikimate pathway in the malaria parasite Plasmodium falciparum. Antimicrob Agents Chemother. 1999 Jan;43(1):175-7.

[67] McConkey GA, Ittarat I, Meshnick SR, McCutchan TF. Auxotrophs of Plasmodium falciparum dependent on p-aminobenzoic acid for growth. Proc Natl Acad Sci U S A. 1994 May 10;91(10):4244-8.

[68] Nowicka B, Kruk J. Occurrence, biosynthesis and function of isoprenoid quinones. Biochim Biophys Acta. 2010 Sep;1797(9):1587-605.

[69] de Macedo CS, Uhrig ML, Kimura EA, Katzin AM. Characterization of the isoprenoid chain of coenzyme Q in Plasmodium falciparum. FEMS Microbiol Lett. 2002 Jan 22;207(1):13-20.

[70] Bentinger M, Tekle M, Dallner G. Coenzyme Q--biosynthesis and functions. Biochem Biophys Res Commun. 2010 May 21;396(1):74-9.

[71] Tonhosolo R, D'Alexandri FL, Genta FA, Wunderlich G, Gozzo FC, Eberlin MN, et al. Identification, molecular cloning and functional characterization of an octaprenyl pyrophosphate synthase in intra-erythrocytic stages of Plasmodium falciparum. Biochem J. 2005 Nov 15;392(Pt 1):117-26. 
[72] Hackstein JH, Mackenstedt U, Mehlhorn H, Meijerink JP, Schubert H, Leunissen JA. Parasitic apicomplexans harbor a chlorophyll a-D1 complex, the potential target for therapeutic triazines. Parasitol Res. 1995;81(3):207-16.

[73] Stokkermans TJ, Schwartzman JD, Keenan K, Morrissette NS, Tilney LG, Roos DS. Inhibition of Toxoplasma gondii replication by dinitroaniline herbicides. Exp Parasitol. 1996 Dec;84(3):355-70.

[74] Tonhosolo R, D'Alexandri FL, de Rosso VV, Gazarini ML, Matsumura MY, Peres VJ, et al. Carotenoid biosynthesis in intraerythrocytic stages of Plasmodium falciparum. $J$ Biol Chem. 2009 Apr 10;284(15):9974-85.

[75] Breitenbach J, Zhu C, Sandmann G. Bleaching herbicide norflurazon inhibits phytoene desaturase by competition with the cofactors. J Agric Food Chem. 2001 Nov;49(11):5270-2.

[76] Sandmann G. Combinatorial biosynthesis of carotenoids in a heterologous host: a powerful approach for the biosynthesis of novel structures. Chembiochem. $2002 \mathrm{Jul}$ 2;3(7):629-35.

[77] Sato S, Clough B, Coates L, Wilson RJ. Enzymes for heme biosynthesis are found in both the mitochondrion and plastid of the malaria parasite Plasmodium falciparum. Protist. 2004 Mar;155(1):117-25.

[78] Johnson TW, Shen G, Zybailov B, Kolling D, Reategui R, Beauparlant S, et al. Recruitment of a foreign quinone into the $\mathrm{A}(1)$ site of photosystem I. I. Genetic and physiological characterization of phylloquinone biosynthetic pathway mutants in Synechocystis sp. pcc 6803. J Biol Chem. 2000 Mar 24;275(12):8523-30.

[79] Olson RE. The function and metabolism of vitamin K. Annu Rev Nutr. 1984;4:281-337.

[80] Tonhosolo R, Gabriel HB, Matsumura MY, Cabral FJ, Yamamoto MM, D'Alexandri FL, et al. Intraerythrocytic stages of Plasmodium falciparum biosynthesize menaquinone. FEBS Lett. 2010 Dec 1;584(23):4761-8.

[81] Morand OH, Aebi JD, Dehmlow H, Ji YH, Gains N, Lengsfeld H, et al. Ro 48-8.071, a new 2,3-oxidosqualene:lanosterol cyclase inhibitor lowering plasma cholesterol in hamsters, squirrel monkeys, and minipigs: comparison to simvastatin. J Lipid Res. 1997 Feb;38(2):373-90.

[82] Suvarna K, Stevenson D, Meganathan R, Hudspeth ME. Menaquinone (vitamin K2) biosynthesis: localization and characterization of the menA gene from Escherichia coli. J Bacteriol. 1998 May;180(10):2782-7.

[83] Glomset JA, Gelb MH, Farnsworth CC. Prenyl proteins in eukaryotic cells: a new type of membrane anchor. Trends Biochem Sci. 1990 Apr;15(4):139-42.

[84] Crowell DN. Functional implications of protein isoprenylation in plants. Prog Lipid Res. 2000 Sep;39(5):393-408.

[85] Leung KF, Baron R, Seabra MC. Thematic review series: lipid posttranslational modifications. geranylgeranylation of Rab GTPases. J Lipid Res. 2006 Mar;47(3):46775.

[86] Schmidt RA, Schneider CJ, Glomset JA. Evidence for post-translational incorporation of a product of mevalonic acid into Swiss 3T3 cell proteins. J Biol Chem. 1984 Aug 25;259(16):10175-80.

[87] Chakrabarti D, Da Silva T, Barger J, Paquette S, Patel H, Patterson S, et al. Protein farnesyltransferase and protein prenylation in Plasmodium falciparum. J Biol Chem. 2002 Nov 1;277(44):42066-73. 
[88] Field H, Blench I, Croft S, Field MC. Characterisation of protein isoprenylation in procyclic form Trypanosoma brucei. Mol Biochem Parasitol. 1996 Nov 12;82(1):67-80.

[89] Buckner FS, Eastman RT, Nepomuceno-Silva JL, Speelmon EC, Myler PJ, Van Voorhis WC, et al. Cloning, heterologous expression, and substrate specificities of protein farnesyltransferases from Trypanosoma cruzi and Leishmania major. $\mathrm{Mol}$ Biochem Parasitol. 2002 Jul;122(2):181-8.

[90] Ibrahim M, Azzouz N, Gerold P, Schwarz RT. Identification and characterisation of Toxoplasma gondii protein farnesyltransferase. Int J Parasitol. 2001 Nov;31(13):148997.

[91] Lujan HD, Mowatt MR, Chen GZ, Nash TE. Isoprenylation of proteins in the protozoan Giardia lamblia. Mol Biochem Parasitol. 1995 Jun;72(1-2):121-7.

[92] Kumagai M, Makioka A, Takeuchi T, Nozaki T. Molecular cloning and characterization of a protein farnesyltransferase from the enteric protozoan parasite Entamoeba histolytica. J Biol Chem. 2004 Jan 16;279(3):2316-23.

[93] Chakrabarti D, Azam T, DelVecchio C, Qiu L, Park YI, Allen CM. Protein prenyl transferase activities of Plasmodium falciparum. Mol Biochem Parasitol. 1998 Aug 1;94(2):175-84.

[94] de Castro FA, Ward GE, Jambou R, Attal G, Mayau V, Jaureguiberry G, et al. Identification of a family of Rab G-proteins in Plasmodium falciparum and a detailed characterisation of pfrab6. Mol Biochem Parasitol. 1996 Sep;80(1):77-88.

[95] Jambou R, Zahraoui A, Olofsson B, Tavitian A, Jaureguiberry G. Small GTP-binding proteins in Plasmodium falciparum. Biol Cell. 1996;88(3):113-21.

[96] Moura IC, Wunderlich G, Uhrig ML, Couto AS, Peres VJ, Katzin AM, et al. Limonene arrests parasite development and inhibits isoprenylation of proteins in Plasmodium falciparum. Antimicrob Agents Chemother. 2001 Sep;45(9):2553-8.

[97] Rodrigues Goulart H, Kimura EA, Peres VJ, Couto AS, Aquino Duarte FA, Katzin AM. Terpenes arrest parasite development and inhibit biosynthesis of isoprenoids in Plasmodium falciparum. Antimicrob Agents Chemother. 2004 Jul;48(7):2502-9.

[98] AbouLaila M, Sivakumar T, Yokoyama N, Igarashi I. Inhibitory effect of terpene nerolidol on the growth of Babesia parasites. Parasitol Int. 2010 Jun;59(2):278-82.

[99] Singh AP, Zhang Y, No JH, Docampo R, Nussenzweig V, Oldfield E. Lipophilic bisphosphonates are potent inhibitors of Plasmodium liver-stage growth. Antimicrob Agents Chemother. $2010 \mathrm{Jul} ; 54(7): 2987-93$.

[100] Jordao FM, Saito AY, Miguel DC, de Jesus Peres V, Kimura EA, Katzin AM. In vitro and in vivo antiplasmodial activities of risedronate and its interference with protein prenylation in Plasmodium falciparum. Antimicrob Agents Chemother. 2011 May;55(5):2026-31.

[101] Hjertman M, Wejde J, Dricu A, Carlberg M, Griffiths WJ, Sjovall J, et al. Evidence for protein dolichylation. FEBS Lett. 1997 Oct 27;416(3):235-8.

[102] D'Alexandri FL, Kimura EA, Peres VJ, Katzin AM. Protein dolichylation in Plasmodium falciparum. FEBS Lett. 2006 Nov 27;580(27):6343-8. 